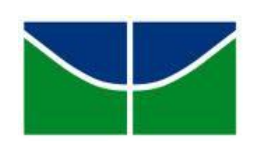

UNIVERSIDADE DE BRASÍLIA

PROGRAMA DE PÓS-GRADUAÇÃO EM GEOGRAFIA

MESTRADO

O desenvolvimento territorial rural e as políticas públicas de estímulo à agroecologia: um caso em Brazlândia

Sophia da Costa Lacerda

Dezembro de 2016 
UNIVERSIDADE DE BRASÍLIA

PROGRAMA DE PÓS-GRADUAÇÃO EM GEOGRAFIA

MESTRADO

O desenvolvimento territorial rural e as políticas públicas de estímulo à agroecologia: um caso em Brazlândia

Sophia da Costa Lacerda

Dissertação de Mestrado apresentada ao Departamento de Geografia, Universidade de Brasília, como requisito necessário à obtenção do Título de Mestre em Gestão Ambiental e Territorial.

Orientadora: Prof ${ }^{a}$. Dr. ${ }^{a}$ Gloria Maria Vargas López de Mesa

Brasília, Distrito Federal

Dezembro de 2016 


\author{
UNIVERSIDADE DE BRASÍLIA \\ PROGRAMA DE PÓS-GRADUAÇÃO EM GEOGRAFIA \\ MESTRADO
}

\title{
O desenvolvimento territorial rural e as políticas públicas de estímulo à agroecologia: um caso em Brazlândia
}

\author{
Sophia da Costa Lacerda
}

Dissertação de Mestrado submetida ao Departamento de Geografia da Universidade de Brasília como parte dos requisitos necessários à obtenção do Grau de Mestre em Geografia, área de concentração Gestão Ambiental e Territorial, opção Acadêmica.

Aprovado por:

Gloria Maria Vargas López de Mesa, Doutora (GEA/UNB). (Orientadora)

Cristina Maria Costa Leite, Doutora (FE/UNB).

(Examinadora Interna)

Janine Mello dos Santos, Doutora (UFABC).

(Examinadora Externa)

Brasília, Dezembro de 2016. 
LACERDA, SOPHIA DA COSTA.

O desenvolvimento territorial rural e as políticas públicas de estímulo à agroecologia:

um caso em Brazlândia. 179 p., 297 mm, (UNB-POSGEA, Mestre, Gestão Ambiental e Territorial, 2016).

Dissertação de Mestrado - Universidade de Brasília. Departamento de Geografia.

1. Desenvolvimento territorial rural 2. Políticas Públicas

3. Agroecologia

É concedida à Universidade de Brasília permissão para reproduzir cópias desta dissertação e emprestar ou vender tais cópias somente para propósitos acadêmicos e científicos. Ao autor reservam-se outros direitos de publicação. Nenhuma parte desta dissertação pode ser reproduzida sem a autorização por escrito do autor.

Sophia da Costa Lacerda 
"Digo: o real não está na saída nem na chegada, ele se dispõe para a gente é no meio da travessia"

Guimarães Rosa 


\section{AGRADECIMENTOS}

Agradeço primeiramente a Deus pela inspiração e por me possibilitar conhecer um pouco mais sobre um aspecto da realidade deste mundo.

Agradeço aos meus pais pelo apoio de diferentes formas. A minha mãe por estar disposta e não medir esforços para colaborar com alcance dos meus objetivos. E ao meu pai por me ensinar que sempre haverá uma forma de superar as dificuldades.

Aos amigos de perto e de longe pelas palavras de motivação e por apontarem os caminhos quando não conseguia mais enxergá-los.

Devo agradecer também aos agricultores de Brazlândia, sem os quais não seria possível a realização desta pesquisa. Também agradeço aos extensionistas da Empresa de Assistência Técnica e Extensão Rural do Distrito Federal que me permitiram compreender um pouco mais sobre a atuação da empresa.

Por fim, agradeço a Professora Doutora Gloria Maria Vargas López de Mesa por neste trabalho compartilhar os seus conhecimentos comigo. 


\section{RESUMO}

A partir da década de 1990 as políticas públicas de desenvolvimento rural ganharam novos contornos, passando a fortalecer a agricultura familiar e reconhecer o protagonismo dos territórios nos processos de desenvolvimento. Esta abordagem diferenciada de políticas para o rural também permite que a dimensão ambiental dos territórios possa ser valorizada através da implementação de práticas agrícolas sustentáveis. Neste contexto a Assistência Técnica e Extensão Rural - ATER pode ser uma das instituições públicas responsáveis por promover um desenvolvimento rural sustentável e de base territorial. No Distrito Federal, Brazlândia é uma das Regiões Administrativa com fortes características rurais e recentemente foi atendida pela Empresa de Assistência Técnica e Extensão Rural do Distrito Federal (EMATER-DF) com ações de estímulo às práticas agrícolas sustentáveis. Dado este contexto, a pesquisa teve como objetivo analisar o desenvolvimento territorial rural em Brazlândia através do Programa Agroecologia da Emater-DF. Para tanto estudou a literatura existente na área de políticas públicas, geografia e agroecologia sobre o desenvolvimento territorial e suas implicações no que se refere à territorialidade. Além disso, também foram realizadas entrevistas com agricultores e extensionistas da Emater -DF que foram responsáveis pelo Projeto Sustentabilidade em Brazlândia, ação dentro do escopo do Programa Agroecologia. Concluiuse que apesar do Projeto Sustentabilidade ter contribuído para compreensão sobre a importância da questão ambiental na agricultura, ele não foi efetivo de modo a causar modificações sobre o uso do território. A Emater-DF é um ator de grande relevância no território rural de Brazlândia, mas a sua atuação no estímulo às práticas agrícolas sustentáveis ainda precisa ser melhor estruturada dentro da empresa. Ademais se reconheceu que a constituição de processos de desenvolvimento em direção a uma agricultura de base agroecológica dependem dos contextos territoriais e da interação entre os atores. Em Brazlândia a agricultura de abastecimento, seguindo o modelo da agricultura convencional, foi identificada com um dos elementos antagonistas à transição agroecológica.

Palavras-chave: Desenvolvimento territorial rural, políticas públicas, agroecologia. 


\begin{abstract}
Since 1990, rural development public policies have taken new frameworks that promote family farming and recognize the role of the territories in the development process. This single approach of rural policies also considers the environmental dimension of the territories in order to get importance to sustainable agricultural practices. Within this context, the Rural Extension and Technical Assistance Services - Ater, can be one of the public institutions responsible for promoting sustainable and territorially based rural development. In Distrito Federal, Brazlândia is one of the Administrative Regions with strong rural characteristics and has been supported by "Empresa de Assistência Técnica e Extensão Rural do Distrito Federal" (Emater-DF) with actions that reinforce sustainable agricultural practices. The research aimed to analyze the rural territorial development in Brazlândia through the Agroecology Program of Emater-DF. To this end, the literature in the areas of public policy, geography and agroecology were studied in order to understand territorial development and its implications on territoriality. Interviews were conducted with farmers and extensionist Emater DF workers who were responsible for the Sustainability Project in Brazlândia, which is within the scope of the Agroecology Program. One can conclude that despite the Sustainability Project had contributed to understanding the importance of environmental issues in agriculture, the project was not effective to cause modifications on the use of the territory. The Emater-DF is an important actor of Brazlândia rural territory, but its performance in reinforcing sustainable agricultural practices still needs to be better structured inside the institution. Furthermore, it was recognized that the establishment of development processes towards an agroecological agriculture depends on the territorial contexts and the arrangements between the actors. In Brazlândia, supplying agriculture, following the model of conventional agriculture, was identified as one of the antagonistic elements to agroecology transition.
\end{abstract}

Keywords: rural territorial development; public policies; agroecology. 


\section{LISTA DE FIGURAS}

FIGURA 01 Macrozoneamento de Brazlândia................................................... 97

FIGURA 02 Localização de Brazlândia..................................................................... 98

FIGURA 03 Localização da Chapadinha - Brazlândia.............................................. 105

\section{LISTA DE GRÁFICOS}

GRÁFICO 01 Quantidade em toneladas do consumo de agrotóxico no Distrito

Federal

GRÁFICO 02 Evolução das áreas médias em ha dos estabelecimentos agropecuários, Brasil e Distrito Federal - 1970/2006.................................................. 93

\section{LISTA DE QUADROS}

QUADRO 01 Tipologia das regiões rurais........................................................... 22

QUADRO 02 Princípios e objetivos da Lei 12.188/2010......................................... 29

QUADRO 03 Indicadores do Programa Agroecologia da Emater-DF..................... 37

QUADRO 04 Principais formas de Agricultura Alternativa: protagonistas e princípios básicos...................................................................... 57

QUADRO 05 Comparação entre tipos de extensão rural........................................ 70

QUADRO 06 Correspondência entre as Dimensões Analisadas e as Questões do Roteiro de Entrevista aplicado aos agricultores da Chapadinha Brazlândia 


\section{LISTA DE TABELAS}

Tabela 1

Tabela 2

Tabela 3

Tabela 4

Tabela 5

Tabela 6

Tabela 7

Tabela 8
Evolução da população urbana e rural - 1950 a 2010

Número e área total dos estabelecimentos, compreendidos pela modalidade de agricultura familiar e não familiar - Distrito Federal.

Número, área total e área média dos estabelecimentos agropecuários, compreendidos pelas modalidades de agricultura familiar e não familiar - Brasil e Distrito Federal - 2006.

Uso Atual do Solo no Distrito Federal -2013. 94

Produção de Frutas - Brazlândia. 95

Produção de Hortaliças - Brazlândia..................................................... 96

Produção de Grandes Culturas - Brazlândia......................................... 96

Áreas Territoriais - Brazlândia........................................................... 97 


\section{LISTA DE ABREVIATURAS E SIGLAS}

Anater

Ater

ARCAG

CNDRS

DAP

\section{Emater-DF}

FZDF

Incra

MDA

Novacap

PAD-DF

Pnapo

Pronaf

RA
Agência Nacional de Assistência Técnica e Extensão Rural

Assistência Técnica e Extensão Rural

Associação Recreativa e Cultural de Alexandre de Gusmão

Conselho Nacional de Desenvolvimento Rural Sustentável

Declaração de Aptidão de Programa Nacional de Fortalecimento da Agricultura Familiar

Empresa de Assistência Técnica e Extensão Rural do Distrito Federal

Fundação Zoobotânica do Distrito Federal

Instituto Nacional de Colonização e Reforma Agrária

Ministério do Desenvolvimento Agrário

Companhia Urbanizadora da Nova Capital

Programa de Assentamento Dirigido do Distrito Federal

Política Nacional de Agroecologia e Produção Orgânica

Programa Nacional de Fortalecimento da Agricultura Familiar

Região Administrativa 


\section{Sumário}

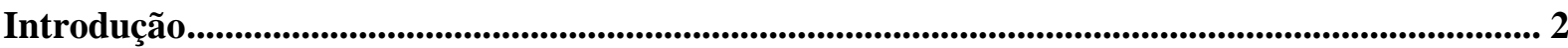

1. As políticas públicas de desenvolvimento territorial rural e o Programa Agroecologia da

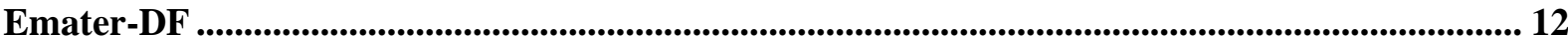

1.1 A abordagem corrente de políticas públicas de desenvolvimento territorial rural ..................... 12

1.2 A Emater- DF no contexto de políticas públicas para o rural Brasileiro..................................... 26

1.3 O Programa de Agroecologia da Emater-DF e as suas especificidades em Brazlândia .............. 33

2. As contribuições da agroecologia ao desenvolvimento territorial rural...................................... 46

2.1 A agroecologia como contraposição ao modelo de agricultura convencional ............................ 46

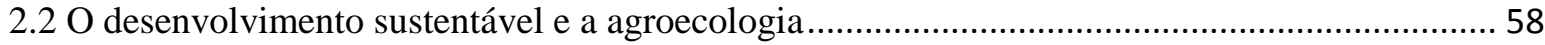

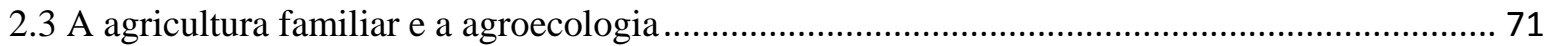

2.4 Território e territorialidade: o uso desses conceitos na compreensão do desenvolvimento

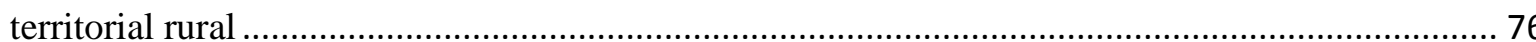

3 As implicações das ações de práticas agrícolas sustentáveis da Emater-DF sobre o

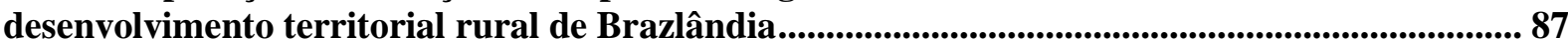

3.1 Contextualização Geográfica de Brazlândia ............................................................................ 87

3.1.1 Modernização Agrícola Dirigida a Região do Centro-Oeste ………………..................... 87

3.1.2 Ordenamento territorial do meio rural do Distrito Federal ................................................. 90

3.1.3 Brazlândia e as características de seu território rural ............................................................ 95

3.2 A incorporação de práticas agrícolas sustentável em Brazlândia e a influência da Emater-DF 103

3.2.1 História de vida e estrutura produtiva das famílias ............................................................ 107

3.2.2 Compreensão das famílias sobre o impacto das suas atividades sobre o meio ambiente... 110

3.2.3 A relação das famílias com a Emater-DF.

3.2.4 Perspectiva dos agricultores entrevistados sobre a transição para modelos produtivos sustentáveis

3.3 A difusão da Agroecologia pela Emater-DF em Brazlândia e sua relação com a territorialidade

4. Considerações Finais 123

5. Referências Bibliográficas 128

ANEXO I - Roteiro de entrevista semiestruturado ao coordenador do Programa Agroecologia da Emater-DF

ANEXO II - Roteiro de entrevista semiestruturado aplicado aos escritórios locais da Emater-DF em Brazlândia

ANEXO III - Roteiro de entrevista semiestruturado aplicado aos agricultores que participaram do Projeto Sustentabilidade na Chapadinha, Brazlândia 


\section{Introdução}

É crescente o consenso de que os espaços rurais brasileiros não apresentam mais apenas uma dimensão de reconhecimento restringida à agricultura para comercialização. Os espaços rurais passam a ser reconhecidos também a partir de uma perspectiva complexa, quando se percebe a capacidade que têm de abrigar atividades não agrícolas e serem um lócus para o desenvolvimento da agricultura familiar multifuncional e pluriativa.

Autores apontam para a existência de uma nova abordagem de desenvolvimento rural, onde as políticas passam a estimular as potencialidades locais, reduzir a pobreza e aumentar o dinamismo econômico, não só através do fomento às atividades agrícolas familiares, mas também pela desconcentração de terras, pelo investimento no capital social ${ }^{1} \mathrm{e}$ pela adoção de uma abordagem territorial (SCHNEIDER, 2004, ABRAMOVAY, 2009, VEIGA, 2001).

Contudo, essa abordagem diferenciada de política pública para o meio rural, onde há espaço para o reconhecimento da sua pluralidade e para a abordagem territorial de seus problemas, é relativamente recente.

As origens desta abordagem remontam a década de 1990. A partir daquele década, devido a pressões de movimento sociais e a disseminação de estudos que apontavam para a necessidade do estímulo à agricultura familiar em um novo contexto de ruralidade, o Estado brasileiro passou a estruturar políticas para fortalecer a agricultura familiar através da perspectiva da territorialidade, pluriatividade e multifuncionalidade da agricultura familiar.

A demanda por um novo pacote de políticas para o meio rural se justificava pela constatação de que o modelo de desenvolvimento conduzido pelo Estado na modernização agrícola da década de 1970 acarretara custos ambientais e sociais ${ }^{2}$ das mais diversas ordens. Tais custos ocorreram pelo fato das instituições governamentais terem considerado o rural brasileiro como sendo um espaço unidimensional que deveria abrigar apenas uma determinada atividade econômica orientada por padrões técnicos definidos de forma exógena ao território.

\footnotetext{
${ }^{1}$ Abramovay (2009) observa que o elemento diferencial para determinar o desenvolvimento em territórios seria o capital social. Entendendo que o capital social corresponde aos atributos substantivos que permitem uma maior coordenação entre os atores do território para uma maior eficiência na utilização dos recursos disponíveis.

2 Ehlers (1999) aponta como implicações do processo acelerado de modernização agrícola o aumento da concentração de terras, o intenso fluxo populacional, direcionado aos grandes centros urbanos não preparados para recebê-lo, e a contaminação de solos e desestabilização de ecossistemas por causa do consumo elevado de fertilizantes e defensivos agrícolas.
} 
A atividade econômica estimulada à época no rural brasileiro era uma agricultura que adotava os princípios da Revolução $\operatorname{Verde}^{3}$ e, dessa forma, exigia dos agricultores a adaptação de seus modelos produtivos a um determinado receituário que visava aumentar a produtividade de gêneros alimentícios através da industrialização da agricultura.

Em contraposição ao modelo de políticas para o campo que se apresentava hegemônico até os finais dos anos 1980, houve a necessidade do desenvolvimento de um novo contexto institucional para promoção das políticas de desenvolvimento rural. Este novo contexto institucional passou a se constituir a partir dos finais dos anos 1990, sendo orientado pelo propósito de valorização da agricultura familiar e dos territórios rurais. Neste sentido, a implementação de políticas públicas passou a ser viabilizada por meio da descentralização do poder decisório e da construção de redes de políticas públicas envolvendo diversos atores de diferentes instâncias de poder. Vale mencionar alguns marcos importantes para a conformação de tal contexto institucional, sendo eles: a criação do Programa Nacional de Fortalecimento da Agricultura Familiar (Pronaf) em 1995, instituição do Ministério do Desenvolvimento Agrário (MDA) no ano 2000, o fortalecimento da Política de Assistência Técnica e Extensão Rural no início dos anos 2000 e implantação de instâncias de participação social, como o Conselho Nacional de Desenvolvimento Rural Sustentável (CNDRS).

Até recentemente, as políticas para o desenvolvimento rural têm priorizado uma abordagem territorial. A abordagem territorial das políticas públicas é decorrente de três fatores: i) a constatação de que o rural não pode ser entendido apenas pela perspectiva agrícola, ii) a valorização da descentralização a nível local para o alcance de melhores resultados nas políticas públicas, iii) reconhecimento do território como unidade mais adequada para o desenvolvimento das ações que buscam o desenvolvimento (DELGADO E LEITE, 2013).

A abordagem territorial orienta a elaboração de análises que tenham como foco as construções sociais dos territórios e que considerem, para delimitação e caracterização dos territórios, os fatores culturais, econômicos, sociológicos, físicos/naturais. O território, neste contexto, é visto como resultante de um processo que envolve a inter-relação dos diversos agentes locais. Dessa forma, a abordagem territorial acaba por valorizar o papel dos agentes econômicos e atores sociais na configuração e implantação dos projetos estratégicos para o desenvolvimento do território que pertencem (MALUF, 2013).

\footnotetext{
3 A Revolução Verde visava o aumento dos índices de produtividade agrícola através da aplicação de um conjunto de práticas tecnológicas que consistiam na melhoria genética das espécies e no aumento da quantidade de insumos externos a propriedade, envolvendo a utilização de fertilizantes químicos, agrotóxicos, irrigação e motomecanização (Ehlers, 1999: 32)
} 
Outro elemento que tem ganhando relevância dentro das políticas de desenvolvimento rural, é o reconhecimento da capacidade pluriativa das famílias agrícolas. Compreende-se que tais famílias não são capazes apenas de adotar atividades agrícolas como forma de garantia de renda, já que cada vez mais diversificam suas fontes de renda devido às oportunidades econômicas que lhe são apresentadas. Neste sentido, os núcleos familiares passam a direcionar a força de trabalho para atividades não agrícolas, tais como as relacionadas com o setor de serviços presente no meio rural, atividades ligadas ao turismo ou a nichos especiais de mercados e, ainda, nas localidades onde há uma interconexão maior entre o rural e urbano, membros da família podem possuir empregos na cidade com o intuito de complementar renda e ocupar o tempo que deixou de ser gasto com as atividades agrícolas.

Além disso, a agricultura familiar deixa de ser caracterizada somente como uma atividade econômica e passa a ser entendida também pela sua multifuncionalidade. $\mathrm{O}$ conceito de multifuncionalidade sofreu influência dos debates sobre os significados do desenvolvimento sustentável. Segundo Sabourin (2008), a partir da Eco 92, a multifuncionalidade é caracterizada como sendo o "reconhecimento pela sociedade do interesse público ou geral de funções sociais, ambientais, econômicas ou culturais, não diretamente produtivas ou não mercantis e associadas à atividade agropecuária”. Assim sendo, percebe-se que a agricultura familiar contribui para preservação do meio ambiente e é fundamental para promoção de alimentos saudáveis a partir do momento que adota práticas que utilizam os recursos naturais de forma sustentável.

A agroecologia neste cenário tem sido um importante instrumento para o reconhecimento da multifuncionalidade dos espaços rurais, na medida em que estimula a adoção de princípios e conceitos diferenciados na agricultura familiar, contribuindo para um desenvolvimento rural sustentável do território.

Dado este panorama de existência de uma abordagem diferenciada de desenvolvimento rural e de uma nova institucionalidade de governo para a execução das políticas públicas, as ações conduzidas pelo poder público que buscam melhorar as condições de vida das populações dos territórios rurais passariam a ter que incorporar as seguintes dimensões inter-relacionadas: fortalecimento da agricultura familiar, valorização dos atributos presentes no território e estimulo às práticas agrícolas sustentáveis, com vistas a reduzir os impactos negativos das intervenções públicas sobre os territórios rurais.

A presente pesquisa buscou concentrar os esforços na compreensão do último aspecto, isto é, do estímulo às práticas agrícolas sustentáveis, especificamente no território 
rural de Brazlândia, por meio da análise do Programa Agroecologia da Empresa de Assistência Técnica e Extensão Rural do Distrito Federal - Emater-DF. Tendo em vista o propósito da pesquisa, optou-se por verificar, através de um caso empírico, como as diretrizes do Programa Agroecologia puderam se concretizar. Neste sentido, a pesquisa abordou o caso empírico do Projeto Sustentabilidade na comunidade de Chapadinha em Brazlândia.

A Assistência Técnica e Extensão Rural - Ater tem sido uma das principais ferramentas utilizadas pelo poder público para estruturar as atividades produtivas nos territórios rurais, promover o desenvolvimento rural e, consequentemente, melhorar as condições vida das famílias que ali residem.

A agroecologia tem ocupado um importante papel dentro da política de Ater pelo fato de contribuir para o fomento de técnicas de manejo agrícola que se adaptam às condições dos ecossistemas e consideram elementos socioculturais da localidade.

A agroecologia permitiria o surgimento de uma agricultura sustentável, pelo fato de suas práticas prezarem pela conservação da biodiversidade ecológica e cultural da localidade. Seria possível por meio da agroecologia implantar modelos de produção agrícola alternativos, onde a produção seria baseada em conceitos ecológicos, levaria em conta o conhecimento local e valorizaria a participação da população rural na construção dos métodos de manejo agrícolas (CAPORAL \& COSTABEBER, 2000, p.29).

A Emater-DF apresenta como missão institucional "promover o desenvolvimento rural sustentável e a segurança alimentar, por meio de Assistência Técnica e Extensão Rural de excelência, em benefício da sociedade do Distrito Federal e Entorno" ${ }^{4}$. Neste sentido, considera como um dos programas prioritários o Programa Agroecologia.

Este programa apresenta dois componentes: a transição agroecológica e o desenvolvimento de sistemas agroecológicos de produção. A transição agroecológica diz respeito às mudanças nas formas de manejo dos agroecossistemas em direção à adoção de métodos e técnicas de base ecológica. As mudanças podem ocorrer em vários níveis, tais como: "redução no uso de insumos convencionais, substituição de práticas e insumos convencionais por técnicas e insumos alternativos e redesenho dos agroecossistemas com elevado aproveitamento dos processos e interações ecológicas" (GLIESSMAN apud EMATER, 2010).

O desenvolvimento de sistemas agroecológicos, por sua vez, se configura em uma etapa mais avançada da transição agroecológica, onde as práticas agrícolas passam a

\footnotetext{
${ }^{4}$ Disponível em:

$<$ http://www.emater.df.gov.br/index.php?option=com_content $\&$ view=article $\&$ id $=47 \&$ Itemid=60>
} 
considerar variáveis ambientais e biofísicas e assim adotam uma "noção de sustentabilidade no sentido temporal em suas várias dimensões: social, econômica, ecológica, política, cultural, ética e também a prioridade para o uso racional de recursos locais admitindo sua combinação com insumos externos" (EMATER -DF, 2010).

A análise da política pública de incentivo à agroecologia conduzida pela Emater-DF em Brazlândia contribui para identificar como o poder público tem incorporado essa abordagem diferenciada de desenvolvimento para os territórios rurais no que tange, especificamente, o reconhecimento dos espaços rurais como sendo multifuncionais e capazes de abrigar uma agricultura alternativa, em consonância com os princípios da agroecologia.

Brazlândia é uma região administrativa do Distrito federal com fortes características rurais que são decorrentes de um processo histórico de ocupação do território. A região primeiramente foi ocupada por famílias que exerciam tradicionalmente atividades agrícolas. Após a transferência da capital para centro do país, Brazlândia se destacou no papel de fornecedora de água para o Distrito Federal e produtora de gêneros alimentícios, principalmente hortaliças e frutas (CHAVES, 2011). Atualmente o território rural é em grande parte ocupado por agricultores familiares. O estímulo a agroecologia neste território através das ações da Emater-DF torna-se relevante para que sejam criadas condições necessárias a um desenvolvimento rural que preze pela multifuncionalidade dos territórios rurais, no que diz respeito à valorização de uma agricultura sustentável.

Dado o contexto exposto, com a finalidade de orientar o desenvolvimento da pesquisa, as seguintes perguntas orientadoras foram elaboradas:

1. De que forma a política de agroecologia da Emater-DF contribui para o desenvolvimento territorial rural de Brazlândia?

2. Quais têm sido as implicações da agroecologia difundida pela Emater-DF sobre a territorialidade de Brazlândia no que se refere à relação dos agricultores com os recursos naturais?

3. A política de agroecologia em Brazlândia induz a valorização do aspecto ambiental do território rural?

É possível observar, então, que a pesquisa aborda duas perspectivas de análise: i) o desenvolvimento rural conduzido pelo poder público por meio de políticas públicas e ii) as implicações deste desenvolvimento sobre o território no que tange a valorização da adoção de práticas agrícolas sustentável em contribuição à multifuncionalidade dos territórios rurais com destaque para dimensão ambiental. Neste sentido, propõe-se como objetivo geral: analisar $o$ 
desenvolvimento territorial rural em Brazlândia através do Programa Agroecologia da Emater-DF. A operacionalização deste objetivo geral foi realizada ao se perseguir os seguintes objetivos específicos: i) verificar de que forma a adoção de práticas agroecológicas por parte dos agricultores familiares estimula o desenvolvimento territorial rural; ii) analisar a influência do Programa Agroecologia na territorialidade dos agricultores familiares de Brazlândia e iii) analisar de que forma o Programa Agroecologia contribui para valorização das práticas agrícolas sustentáveis por parte dos agricultores familiares de Brazlândia.

Como visto há um contexto diferenciado de abordagem de políticas públicas para o rural brasileiro, onde se reconhece que o espaço rural é capaz de abrigar outras atividades para além da econômica e o território ganha uma importância diferenciada no planejamento das intervenções públicas.

A dimensão ambiental do espaço rural passa ser valorizada neste contexto, impulsionando o surgimento de políticas como o Programa Agroecologia da Emater-DF que busca trazer ao território rural de Brazlândia práticas agrícolas alternativas que colaborem com a redução dos danos aos recursos naturais. Desse modo, partirmos da hipótese de que $a$ política pública de agroecologia da Emater - DF contribui para o desenvolvimento territorial rural de Brazlândia na medida em que induz o uso do território de forma mais sustentável.

Contudo, é preciso aprofundar o conhecimento empírico sobre tal abordagem de políticas públicas, ao ponto de identificar se não passa apenas de um discurso presente no plano das ideias ou é capaz de efetivamente provocar alterações na realidade concreta a fim de promover um desenvolvimento territorial adequado ao rural. Neste sentido, torna-se pertinente o estudo deste caso específico de política pública conduzida por uma instituição pública em um determinado território devido a dois principais fatores.

O primeiro se refere à natureza da instituição responsável pelo Programa Agroecologia. A Emater-DF apresenta um alinhamento com os princípios desta abordagem diferenciada de desenvolvimento rural que estão transparecidos na missão da empresa e também podem ser percebidos na forma como estrutura suas ações, as quais se direcionam ao pequeno produtor e não se concentram somente na atividade agrícola por si mesma. $\mathrm{O}$ segundo fator se relaciona com as características do território rural de Brazlândia. Esta Região Administrativa é tradicionalmente rural e possui grande presença de pequenos agricultores que se dedicam a produção de alimentos para o Distrito Federal e começam a adotar práticas de cultivo alternativas. 
Neste sentido, a escolha da política, da instituição e do território contribui para que se compreenda como a intervenção pública interfere sobre o território rural de forma a contribuir com a sua multifuncionalidade e assim exercer uma influência efetiva sobre o desenvolvimento territorial rural.

Para que as pretensões da pesquisa pudessem ser respondidas, houve a necessidade de se fazer um aporte interdisciplinar, já que a análise do objeto de estudo requereu o aporte de diferentes campos do saber. O estudo das políticas públicas de desenvolvimento territorial e as suas implicações sobre a territorialidade contou com as contribuições da geografia e do campo de conhecimento próprio das políticas públicas. Além disso, como a pesquisa se propôs a evidenciar a dimensão ambiental do desenvolvimento, a agroecologia ganhou uma atenção específica durante o desenvolvimento da pesquisa. Dessa forma, puderam ser trabalhadas as interfaces entre disciplinas de forma a proporcionar uma articulação entre saberes.

No que se refere às questões metodológicas da pesquisa, podemos definir que ela foi de caráter explicativo e teve uma abordagem qualitativa do fenômeno estudado que se refere à análise do desenvolvimento territorial rural em Brazlândia promovido pelo Programa de Agroecologia da Emater-DF. Neste sentido, pretendeu-se evidenciar os fatores presentes na intervenção pública que atuam sobre o território a fim de modificá-lo em um processo de desenvolvimento que considere a dimensão ambiental. Por isso, foi necessário o emprego de técnicas metodológicas que auxiliaram na compreensão das relações existentes entre os aspectos estudados a fim de explicitar o porquê da ocorrência da indução ou não do uso mais sustentável do território de Brazlândia.

Dadas às necessidades de limitação do escopo da pesquisa, optou-se por traçar um recorte temporal e espacial sobre o qual seriam feitas as análises do objeto estudado e sua contextualização. Neste sentido, a contextualização do objeto requereu a análise da atuação da Emater-DF sobre o território de Brazlândia que foi subsidiada por três etapas. O levantamento histórico-institucional do período de criação da empresa até os dias atuais; o levantamento das diretrizes das políticas de Ater vigentes atualmente, mas que tem os seus delineamentos no início dos anos 2000; e a caracterização do espaço rural de Brazlândia, considerando a influência das políticas de desenvolvimento rural a partir da década de 1960.

A dimensão espacial e temporal da manifestação empírica do objeto estudado compreendeu a verificação da indução do uso sustentável do território de Brazlândia, a partir da análise do Projeto Sustentabilidade, que promoveu atividades entre 2013 e 2016 aos 
agricultores de Brazlândia. Dadas às limitações de tempo e recursos da pesquisa e a necessidade de retratar a influência da empresa sobre um dado contexto territorial, optou-se por circunscrever a análise empírica à comunidade da Chapadinha, composta por agricultores que tradicionalmente exercem atividades agrícolas e possuem direito de uso da terra reconhecido pelos órgãos governamentais.

Os procedimentos metodológicos para realização da pesquisa foram compostos por três etapas. A primeira delas consistiu no levantamento bibliográfico, com o objetivo de proporcionar um maior entendimento da pesquisadora sobre a temática estudada. A revisão bibliográfica foi orientada por três dimensões conceituais: políticas públicas de desenvolvimento rural, agroecologia e território/territorialidade.

No que se refere à dimensão conceitual do desenvolvimento rural, foram selecionados um conjuntos de autores que convergem para o entendimento de que os territórios rurais são multifuncionais, capazes de abrigar modelos diversos de desenvolvimento e que a pobreza do meio rural deve de ser combatida por meio de ações estruturantes que fortaleçam as potencialidades de cada localidade e a agricultura familiar (ABRAMOVAY, 2009; FAVARETO, 2006; GRAZIANO DA SILVA E CAMPANHOLA, 2004; SABOURIN, 2008; SCHNEIDER, 2004; VEIGA, 2001).

A dimensão conceitual da agroecologia teve como ponto de partida o entendimento de que esse campo de conhecimento contribui para o reconhecimento da multifuncionalidade dos territórios rurais e possibilita que os processos de desenvolvimento sejam direcionados para uma dimensão sustentável. Desse modo, entendemos que as pretensões e contribuições da agroecologia "vão muito além dos aspectos meramente tecnológicos ou agronômicos da produção, incorporando dimensões mais abrangentes e complexas que incluem tanto variáveis econômicas, sociais e ambientais, como variáveis culturais, políticas e éticas da produção agrícola" (CAPORAL e COSTABEBER, 2000, p.27). Neste sentido foram feitas leituras dos seguintes autores que estudam a agroecologia: Caporal e Costabeber (2000), Guzmán (2005), Gomes (2005) e Gliessman (2001).

No que tange a dimensão conceitual referente ao território/territorialide, selecionamos as contribuições de relevantes teóricos da Geografia, Milton Santos, Claude Raffestin e Jöel Bonnemaison. Tais teóricos possuem visões diferentes sobre o território, contudo as diferentes óticas auxiliarão no entendimento mais aprofundado das questões levantadas por esta pesquisa. Neste sentido, os impactos dos processos de desenvolvimento para o rural e as influências dos diferentes atores sobre estes processos, são analisados pelas contribuições de 
Santos e Raffestin; já as contribuições de Bonnemaison serão aportadas para o entendimento da forma como os princípios da agroecologia são incorporados pelos agricultores em uma perspectiva simbólica.

Após o levantamento bibliográfico, foi realizada a segunda etapa dos procedimentos metodológicos que consistiu na caracterização do contexto espacial de Brazlândia e da atuação da Emater-DF, no que se refere o escopo do Programa Agroecologia. Esta etapa se fundamentou na análise documental e no levantamento de dados socioeconômicos secundários sobre Brazândia. Os documentos compreenderam: materiais de divulgação do Programa Agrecologia, relatórios de atividades do programa Agroecologia, documentos institucionais sobre o Programa Sustentabilidade, registros administrativos da Emater-DF referentes aos atendimento em Brazlândia. As fontes dos dados socioeconômicos foram os relatórios da Pesquisa Distrital por Amostra de Domicílios (PDAD) e da pesquisa Agricultura Familiar no Distrito Federal, ambas da Companhia de Planejamento do Distrito Federal Codeplan.

A última etapa dos procedimentos metodológicos foi de grande importância para a compreensão acerca da influência do programa sobre a territorialidade de Brazlândia. Essa etapa se constituiu na realização de entrevistas semiestruturadas com os técnicos da EmaterDF, nos dias 14/10/2015, 14/04/2016 e 01/07/2016, e com os agricultores que participaram do Projeto Sustentabilidade pertencentes a comunidade de Chapadinha. Foram entrevistados, por meio de roteiros de entrevista semiestruturados, três extensionistas da Emater-DF, estes extensionistas ocupavam as seguintes posições na estrutura organizacional da empresa: coordenador do Programa Agreocologia no escritório sede da empresa em Brasília, gerente do escritório de Alexandre Gusmão e técnico extensionista do escritório de Brazlândia.

Além das entrevistas com os extensionistas da Emater-DF, também foram realizadas entrevistas semiestruturadas com 8 agricultores da comunidade da Chapadinha em Brazlândia entre julho e agosto de 2016 que foram acompanhados através do Projeto Sustentabilidade durante aproximadamente dois anos (2013 a 2015). A comunidade foi selecionada para ser objeto da pesquisa de campo porque abriga agricultores com perfis semelhantes de estrutura produtiva e, além disso, já apresenta uma tradição na produção de hortaliça. Ainda quanto ao perfil dos agricultores entrevistados, são agricultores que desenvolvem atividades agrícolas em unidades produtivas capazes de garantir a renda familiar e todos se enquadram como agricultores familiares, sendo assim, possuem em média 5 hectares e a família é responsável pela gestão do empreendimento e também trabalha na propriedade. 
A amostra dos agricultores desta comunidade que participaram da entrevista foi selecionada conforme o método bola de neve. A composição da amostra, seguindo o método bola de neve, se formou a partir das indicações dos agricultores. Cada agricultor que participava da entrevista indicava outro agricultor, que também havia participado do Projeto Sustentabilidade, para ser convidado a participar da pesquisa. As entrevistas foram realizadas nas propriedades dos agricultores e não contaram com a presença dos técnicos da Emater-DF. Dessa forma, os agricultores puderam declarar, sem constrangimentos, as impressões que têm sobre a atuação da empresa.

As análises das entrevistas seguiram as dimensões temáticas das informações que a pesquisadora intencionava obter através da aplicação dos questionários. Tais dimensões temáticas compreenderam: i) a história de vida e estrutura produtiva das famílias, ii) a compreensão das famílias sobre o impacto das suas atividades sobre o meio ambiente, iii) relação das famílias com a Emater-DF e iv) percepção sobre as vantagens e desvantagens de produções agrícolas mais sustentáveis. As análises realizadas por meio das dimensões temáticas possibilitaram a compreensão do contexto territorial de Brazlândia, o entendimento da percepção dos agricultores quanto às práticas agrícolas sustentáveis e à atuação da EmaterDF.

Além dessa introdução, que se preocupou em abordar aspectos sobre o desenho da pesquisa e os objetivos perseguidos, a presente dissertação é composta por três capítulos. $\mathrm{O}$ primeiro capítulo discorre sobre o contexto atual de políticas públicas de desenvolvimento territorial rural, aborda o papel da Emater-DF neste contexto e apresenta os elementos estruturais do Programa Agroecologia e do Projeto Sustentabilidade. No segundo capítulo são trazidas as discussões existentes sobre os significados da agroecologia e do desenvolvimento sustentável, assim como também aborda a perspectiva teórica sobre território e territorialidade adotada pela pesquisa. O terceiro capítulo se preocupa com a análise da influência da EmaterDF sobre a incorporação de práticas agrícolas sustentáveis no território rural de Brazlândia, sendo assim, apresenta o contexto socioespacial de Brazlândia e analisa os resultados da pesquisa de campo realizada na comunidade da Chapadinha em Brazlândia. 


\section{As políticas públicas de desenvolvimento territorial rural e o Programa Agroecologia da Emater-DF}

O presente capítulo tem como objetivo demonstrar de que forma o Programa Agroecologia da Emater-DF se insere no contexto das atuais políticas públicas estruturadas para proporcionar uma melhor qualidade de vida às famílias que fazem parte dos territórios rurais, dando um especial destaque ao desenvolvimento deste programa em Brazlândia. Para tanto, o capítulo é estruturado em três seções. A primeira pretende discorrer sobre a abordagem corrente de políticas públicas de desenvolvimento territorial rural, a segunda seção se preocupa com a contextualização da instituição da Emater-DF no cenário das políticas públicas para o rural contemporâneo e, por fim, a última seção discorre sobre os componentes estruturais do Programa Agroecologia e do Projeto Sustentabilidade em Brazlândia.

\subsection{A abordagem corrente de políticas públicas de desenvolvimento territorial rural}

A partir do início da década de 1990, a literatura que tem como foco de análise o rural brasileiro e as políticas públicas nele fomentadas começou a expandir a sua visão sobre os significados do rural. Tornou-se cada vez mais evidente que a dimensão econômica, no que se refere à atividade agrícola por si só, não é suficiente para explicar a complexidade deste espaço em nossa contemporaneidade. Além disso, perceberam-se os custos ambientais, sociais e econômicos, gerados pelos modelos de desenvolvimento impostos aos territórios rurais, considerando estes como espaços vazios e passivos.

Neste sentido, determinadas noções, tais como: pluriatividade da agricultura familiar, multifuncionalidade e a abordagem territorial das políticas públicas, foram desenvolvidas ou readaptadas com intuito de proporcionar uma maior compreensão sobre o papel que o rural brasileiro tende a desempenhar no cenário atual.

Com intuito de transparecer o que vem a ser o rural brasileiro de nossos dias e em que consistem as políticas públicas formuladas para proporcionar melhor qualidade de vida às famílias que ali residem, a presente seção do primeiro capítulo desta dissertação apontará as consequências da modernização da segunda metade do século XX para o rural brasileiro, trará as contribuições de estudos que têm abordado a existência de um novo rural e relacionará este contexto a um perfil diferenciado de políticas públicas de desenvolvimento territorial rural. 
Os processos de modernização ${ }^{5}$ da sociedade brasileira iniciados na segunda metade do século XX podem ser considerados como um dos fatores que explicam as mudanças que são observadas atualmente no que se refere à ruralidade brasileira. Naquele momento havia um anseio por parte das elites que o Brasil se inserisse de forma célere na tendência de modernidade que se apresentava no cenário global, o que significava recorrer à industrialização atrelada à urbanização, para que desta forma se atingisse o discurso de progresso da época.

A modernização adotada pelo país era justificada pela necessidade de inserir a economia no capitalismo global, o que requereria o desenvolvimento da indústria e dos centros urbanos para que estes desempenhassem o papel de concentrar o consumo e a circulação da produção. O rural cada vez mais passou a ser visto como necessário apenas para fornecer matérias primas e mão de obra de baixo custo, resultante da desapropriação dos camponeses de seus modos de vida tradicionais.

Os grandes planos governamentais da segunda metade do século XX foram responsáveis por materializar as intenções de um planejamento que tinha o intuito de acelerar o processo de modernização. Como destaca Araujo (1993) estes grandes planos pretendiam projetar o Brasil como uma economia moderna, capaz de tomar parte ativa de um novo processo do capitalismo global que se iniciava a época.

$\mathrm{Na}$ perspectiva de Costa (2000) os planos conduzidos pelos governos militares tinham uma lógica própria que valorizava o interesse do capital em detrimento de um olhar mais acurado para os territórios, segundo o autor "não se tratava ali de um plano para o território (o que é óbvio), mas de um plano para a expansão capitalista do país em sua etapa industrial" (COSTA, 2000, p. 54).

Neste período é possível identificar quatro processos que conduziam as modificações em todo o território nacional, sendo eles: a ampliação da articulação comercial, a integração produtiva, a inserção na economia mundial e a integração físico-territorial (LEONARDO GUIMARÃES apud ARAUJO, 1993).

A estratégia governamental de intervenção econômica e territorial foi efetiva para que se alcançasse as taxas de crescimento almejadas, porém nem todos puderam tomar parte dos benefícios decorrentes de uma melhoria no cenário econômico do país. Para exemplificar analisemos indicadores de um período deste processo. Lago (1990) observa que entre 1968 e 1973 o PIB apresentou altas taxas de crescimento, tendo uma média de 11,2\% ao ano para o

\footnotetext{
${ }^{5}$ Pela perspectiva de Milton Santos, os processos de modernização acarretam profundas mudanças sobre um dado sistema socioespacial e "criam novas atividades ao responder a novas necessidades" (Santos, 1985, p.32).
} 
período, porém houve um agravo da concentração de renda, os 5\% mais ricos que em 1960 detinham 28,3\% da renda nacional, em 1972 passaram a ter 39,8\% (LAGO, 1990, p. 290).

Quando analisamos como o rural é percebido pelas inciativas governamentais daquele momento, notamos que ele era reconhecido como um espaço que abrigava modos de vida arcaicos e atrasados que não coincidiriam com a modernização que se mostrava indispensável para o desenvolvimento do país. Chegou-se a pensar na extinção natural daquele rural, já que como apontam Miranda e Silva:

\begin{abstract}
a modernização da agricultura e a urbanização do campo terminariam por transformar internamente o mundo rural, e mesmo destituí-lo de sua substância, pela integração aos processos gerais da acumulação capitalista, único motor do desenvolvimento nacional. A generalização da relação direta capital-trabalho se estenderia plenamente sobre atividade agrícola, de modo que, aos camponeses só restariam a alternativa da própria autodestruição e autonegação, pela migração e pela proletarização (MIRANDA e SILVA, 2013, p. 433).
\end{abstract}

A modernização da agricultura foi vista como necessária para que as técnicas agrícolas consideradas rudimentares pudessem ser substituídas por outras técnicas mais adequadas à sustentação de um modelo produtivo que requeria taxas de retorno crescentes. Dessa forma, a agricultura deveria se transformar para viabilizar o fornecimento de gêneros alimentícios a baixo custo aos centros urbanos crescentes, adotar um caráter industrial para se inserir de forma adequada na dinâmica econômica emergente e contribuir para geração de excedentes nas transações comerciais do mercado exterior.

Os impactos decorrentes do processo de modernização agrícola foram significativos para uma nova constituição do rural brasileiro. A agricultura exerce influência sobre os significados da relação do homem com a natureza e, assim sendo, é capaz de, em certa medida, interferir sobre a constituição dos espaços rurais.

A modernização da agricultura se intensificou através da implementação de políticas para o campo orientadas pelos princípios da Revolução Verde ${ }^{6}$ nos finais da década de 1960. A atuação do Estado através de um pacote específico de políticas foi fundamental para que as mudanças ocorressem de forma efetiva e em curto prazo. O Estado atuou basicamente em três frentes: financiamento de pesquisas para o aumento da produtividade, incentivo ao consumo de insumos agrícolas e fornecimento de crédito rural (EHLERS, 1999).

\footnotetext{
${ }^{6}$ A Revolução Verde visava o aumento dos índices de produtividade agrícola através da aplicação de um conjunto de práticas tecnológicas que consistiam na melhoria genética das espécies e no aumento do consumo de insumos agrícolas tais como: fertilizantes químicos, agrotóxicos, irrigação e motomecanização (Ehlers, 1999: 32).
} 
O aumento do uso de insumos e maquinários agrícolas, bem como os níveis de produtividade alcançados na época, retratam o grande impacto da intervenção estatal na agricultura. No período de 1967 a 1975, o aumento da produção agrícola acompanhou uma taxa de 4,7\% ao ano. Além disso, ocorreu um aumento no uso de fertilizantes (mais de seis vezes), de defensivos agrícolas (quase quatro vezes), e de tratores (quase três vezes). (GRAZIANO DA SILVA, 1981, p. 27).

Todavia as políticas de incentivo à modernização da agricultura eram voltadas somente para aquelas culturas consideradas altamente lucrativas e chamadas de modernas, pois consumiam quantidades maiores de insumos e áreas para a produção. Eram quase sempre voltadas para o mercado exportador e/ou para transformação industrial (GRAZIANO DA SILVA, 1981, p. 30).

Como aponta Ehlers (1999), “essa 'modernização' excluiu grande parte dos produtores familiares, que não eram contemplados pelos benefícios governamentais. As monoculturas de grãos, altamente moto-mecanizadas, exigem uma escala de produção mínima que os menores produtores não conseguiam atingir” (EHLERS, 1999, p. 39).

A modernização da agricultura brasileira, que ocorria sobre os princípios da Revolução Verde, acabou por beneficiar a agricultura patronal em detrimento da familiar, favorecendo a concentração de riquezas e o aumento das disparidades regionais. Frente ao contexto desfavorável, os agricultores familiares abandonaram as suas terras e migraram para as cidades ou se tornaram trabalhadores temporários, agravando o problema do desemprego (EHLERS, 1999, p. 44).

Os pequenos agricultores e trabalhadores agrícolas foram compelidos a migrarem para os grandes centros urbanos, porém não encontraram mecanismos para o seu acolhimento. Surgiu assim "um enorme problema social: os excedentes populacionais, a população sobrante, os excluídos, para os quais não existe lugar estável de trabalho e vida, sendo absorvidos pela economia marginal e precariamente" (MARTINS, 1997, p. 72).

A modernização da agricultura juntamente com outros processos de modernização que se iniciaram na década de 1950 alavancou o processo de migração da população rural. Através da tabela abaixo é possível verificar a considerável queda da proporção da população rural entre as décadas de 1950-1980. 
Tabela 1 - Evolução da população urbana e rural - 1950 a 2010

\begin{tabular}{r|r|r|r|r}
\hline Período & Urbana & $\begin{array}{r}\text { \%Pop. } \\
\text { Urbana }\end{array}$ & Rural & $\begin{array}{c}\text { \%Pop. } \\
\text { Rural }\end{array}$ \\
\hline 1950 & 18.782 .891 & 36,16 & 33.161 .506 & 63,84 \\
\hline 1960 & 32.004 .817 & 45,08 & 38.987 .526 & 54,92 \\
\hline 1970 & 52.904 .744 & 55,98 & 41.603 .839 & 44,02 \\
\hline 1980 & 82.013 .375 & 67,7 & 39.137 .198 & 32,3 \\
\hline 1991 & 110.875 .826 & 75,47 & 36.041 .633 & 24,53 \\
\hline 2000 & 137.755 .550 & 81,23 & 31.835 .143 & 18,77 \\
\hline 2010 & 160.925 .792 & 84,36 & 29.830 .007 & 15,64 \\
\hline & \multicolumn{4}{|c}{ Fonte: IBGE }
\end{tabular}

Nesse contexto de modernização agrícola, um determinado modelo de produção foi incentivado, o qual requeria para a produção agrícola grandes extensões de terra e um quantitativo maior de insumos agrícolas. Sob esta lógica parecia, então, que o rural brasileiro havia se esvaziado, tornando-se, prioritariamente, um lugar de produção de gêneros alimentícios e commodities.

Tal processo acarretou custos sociais e ambientais. Uma grande parcela dos agricultores teve que abandonar os seus modos de vida e migrar para centros urbanos incapazes de lhes oferecer condições adequadas para suprir suas carências. No que se refere aos custos ambientais, as novas técnicas produtivas relacionadas à agricultura moderna acabaram por contaminar os ecossistemas, ocasionando desequilíbrios ambientais.

Apesar de a modernização agrícola ter tido a intencionalidade reduzir rural a apenas uma dimensão, reconhecendo-o como lócus para a reprodução de um determinado tipo de agricultura, o rural brasileiro de nossa contemporaneidade emerge como novos significados. A modernização agrícola não foi capaz de eliminar os diferentes projetos para o campo brasileiro, defendidos por atores sociais que após a redemocratização começaram a ter maior participação no processo decisório de políticas públicas.

A partir do estudo da ruralidade em nossa contemporaneidade Miranda e Silva (2013) apontam a existência de seis tendências que têm influenciado os significados do rural brasileiro contemporâneo, sendo elas: i) a mudança no perfil demográfico brasileiro; ii) o ganho de importância competitiva da agricultura no cenário internacional e a sua perda de importância na ocupação de trabalho e formação de rendas; iii) a relevância socioambiental da "nova ruralidade" e as metamorfoses da questão agrária; iv) a convivência de duas formas 
sociais de produção agrícola; v) o uso do território como unidade de planejamento; e vi) o surgimento de uma economia da nova ruralidade.

A perda de população nas regiões e municípios com fortes características rurais tem se estagnado como aponta estudos (MIRANDA e SILVA, 2013 apud VEIGA, 2000) e, além disso, algumas localidades rurais têm sido capazes de atrair populações. Essa inversão na tendência de esvaziamento do campo, marcante na segunda metade do século $\mathrm{XX}$, tem sido justificada por variados fatores, a depender do contexto de cada localidade, tais como: desindustrialização de algumas metrópoles, desconcentração das atividades econômicas, incentivos econômicos para áreas interioranas e transferências de recursos oriundas de programas sociais. Dessa forma, têm sido gestadas condições para que as populações rurais tenham mais atrativos para permanecerem em suas regiões e não serem expulsas devido a uma conjuntura desfavorável.

Apesar de a agricultura ter ganhado uma grande importância na economia do país, representado algo em torno de $12 \%$ do PIB e contribuído com $30 \%$ das exportações, ela não pode ser apontada como elemento crítico para permanência das famílias no campo, já que o modelo produtivo agrícola preponderante tem gerado menos postos de trabalho e a renda gerada por ele tem se mantido concentrada (Miranda e Silva, 2013). As famílias residentes em áreas rurais têm buscado diversificar suas fontes de renda e passam a desenvolver atividades não agrícolas ${ }^{7}$, como aponta estudos (GRAZIANO DA SILVA e CAMPANHOLA, 2004).

Autores identificam a existência de um novo rural (FAVARETO, 2006; ABRAMOVAY, 2009; VEIGA, 2001), onde pode ser reconhecida a pluriatividade da agricultura familiar, a multifuncionalidade dos territórios rurais e a interdependência entre a cidade e o campo. E assim, já se abandona a dicotomia que aponta que o campo é essencialmente agrário e que a cidade é essencialmente urbana.

O avanço da tecnologia que interferiu na modernização das técnicas agrícolas possibilitou que as famílias residentes no campo dedicadas à atividade agrícola não precisassem mais direcionar seu tempo de trabalho exclusivamente ao cultivo da terra ou a qualquer outra atividade que tivesse ligação direta à agricultura. Dessa forma, as famílias contam com um tempo livre maior, tal situação possibilita que os membros tenham condições

\footnotetext{
${ }^{7}$ Graziano da Silva (1997) identifica três grupos principais de atividades não agrícolas que tem ganhado uma maior importância no meio rural. O primeiro grupo são as atividades ligadas às agroindústrias; o segundo grupo engloba as atividades relacionadas com a preservação do meio ambiente e serviços decorrentes da urbanização do campo, tais como moradia, turismo, lazer dentre outros; já o terceiro grupo corresponde a "proliferação de sítios de recreio", ou seja, áreas destinadas ao lazer das famílias de classe média e que possuem o acesso facilitado através de rodovias pavimentadas.
} 
de incentivo para se dedicarem a atividades não agrícolas. Por isso, núcleos familiares pluriativos surgem cada vez mais.

A multifuncionalidade dos territórios rurais aparece neste cenário quando se percebe que o rural não é somente agrícola e pode gerar outros benefícios sociais. Neste sentido, a multifuncionalidade é entendida a partir das externalidades positivas que a agricultura familiar pode produzir e da constatação de que o meio rural torna-se um bem público, ou seja, "não consiste mais, somente, no espaço físico em que se espalha a produção agropecuária, mas adquire funções sociais que obrigam sua partilha entre uma quantidade muito diversificada de atores" (ABRAMOVAY, 2009, p.127).

A multifuncionalidade é um termo que, embora tenha aparecido com especial destaque nos estudos que abordam a questão da nova ruralidade ${ }^{8}$, também é encontrado na geografia, especificamente, nas análises, que se preocupam com perspectiva da gestão territorial, no que diz respeito às implicações de múltiplos processos em um dado território. $\mathrm{O}$ denominar comum em ambas as abordagens é o reconhecimento de que o rural abriga várias funções que estão para além da atividade agrícola, as quais são determinadas pelos contextos que agem sobre a configuração do território.

A multifuncionalidade aparece como adequada para o entendimento do rural contemporâneo porque permite considerar a relevância das dinâmicas social, ambiental, política e econômica em uma realidade cujo teor de relação homem com a natureza permanece central. Além disso, não é ignorada a existência uma maior interconexão entre os diferentes territórios devido às mais diversas redes que são constituídas em nosso cenário atual, impossibilitando o isolamento espacial. Neste sentido, tornar-se impróprio compreender o rural apenas por sua função produtivista.

Segundo Wilson (apud, MACHADO, 2014), espaços onde há múltiplas interações e múltiplos atores, a multifuncionalidade permite desvendar o caráter dos diferentes usos que são imputados ao território. Entendemos que os processos de níveis escalares diversos e a interação cidade e campo, têm moldado os significados dos diferentes rurais.

Diferentes aspectos devem ser reconhecidos no rural, e conforme o contexto de rural analisado deve ser considerar o protagonismo de variados atores, bem como as peculiaridades

\footnotetext{
${ }^{8}$ Os estudos que apontam para existência de um novo rural, onde a agricultura familiar deve ser valorizada nos processos de desenvolvimento e o rural deixa de ser um espaço exclusivamente destinado à produção de produtos primários, adotaram o termo multifuncionalidade da agricultura familiar. Assim identificam entre as funções da agricultura familiar: permitir a reprodução socioeconômica das famílias rurais; garantir a segurança alimentar das famílias rurais e da sociedade como um todo; contribui para a manutenção do tecido social e das práticas culturais; e exerce um importante papel na preservação dos recursos naturais e da paisagem rural.
} 
das dinâmicas espaciais que vão para além da atividade econômica. Sendo assim, é possível evitar projetos desenvolvimentistas que possuem uma lógica linear de causa-efeito com o intuito de reduzir os territórios rurais a um determinado padrão que os esvazia de sua riqueza de significados.

A multifuncionalidade tem ganhado força nos estudos do rural, porque se entende que o contexto contemporâneo é marcado por um emaranhado de processos advindos de diferentes interesses que intencionam projetar sobre um mesmo espaço diferentes funções. Por isso, da necessidade de desenvolver uma visão abrangente nos estudos sobre o desenvolvimento rural, de modo a considerar a relevância das iniciativas de diferentes atores sobre o território.

Sendo assim, o último elemento a ser destacado desta nova ruralidade seria a maior interconexão entre a cidade e o campo. $O$ avanço da tecnologia e a emergência de uma sociedade da informação ${ }^{9}$ tem provocado um aumento na constituição de redes entre rural e o urbano de diversas ordens, tais como redes de circulação de pessoas, serviços públicos e atividades econômicas. Tais redes têm causado interferências sobre os modos de vida e proporcionam uma maior interdependência entre o urbano e o rural.

A economia deste novo rural, além de receber influências de uma maior conexão entre centros urbanos e as áreas rurais, também é influenciada pelas transferências governamentais que ocorrem através de programas sociais e programas de crédito às atividades agrícolas.

Os estudos feitos por Favareto e Abramovay (apud MIRANDA e SILVA, 2013) sobre a dinâmica econômica nas áreas rurais, apontam que a incidência de melhores indicadores quanto à redução da pobreza e da desigualdade dependeria de uma "conjunção entre a força da economia residencial (com transferência de recursos privados e públicos) com o fornecimento de serviços públicos básicos e políticas que estimulam a inserção mercantil de atividades econômicas de pequena escala" (MIRANDA e SILVA, 2013 p. 446). Nesta perspectiva a atividade agrícola perde a centralidade de ser a promotora de geração de renda, já que a confluência de diferentes fatores aparece como sendo crítica para o alcance um maior dinamismo econômico.

$\mathrm{Na}$ nova ruralidade a questão agrária tem ganhado outros elementos que vão para além da posse da terra e estão relacionados com a forma de utilização dos recursos naturais.

\footnotetext{
${ }^{9}$ Castells (1999) percebe que estaríamos vivendo em uma sociedade da informação, onde o informacionalismo adquire um papel central, regendo todas as relações do mundo, e o conhecimento passa a ser o próprio produto do processo produtivo, não mais se caracterizando como um insumo necessário à industrialização.
} 
Segundo Miranda e Silva (2013) há uma metamorfose da questão agrária entendida por meio de duas dimensões complementares:

\footnotetext{
Por um lado, o significado das formas de posse e uso da terra tem sido um obstáculo à adoção de um estilo de desenvolvimento que se faça acompanhar de maior coesão social e de formas menos agressivas de uso dos recursos naturais. A questão agrária torna-se indissociável da questão regional e da questão ambiental. Por outro lado, se é possível falar em metamorfose da questão agrária, esta se traduz pelas novas representações ideológicas hoje atribuídas ao agronegócio (MIRANDA e SILVA, 2013, p.444)
}

Quanto aos modelos de produção agrícola, haveria duas formas sociais de produção, a agricultura patronal e a agricultura família. Contudo, as diferenças entre elas não se dariam na competitividade de mercado ou na viabilidade econômica em gerar rendas, ambas podem gerar retornos econômicos equivalentes, mas sim nos impactos socioeconômicos e ambientais decorrentes dos modelos produtivos.

Outra tendência identificada por Miranda e Silva (2013) sobre o contexto do rural brasileiro se refere à emergência do território como unidade de análise e planejamento. As instituições governamentais cada vez mais estariam se apropriando de uma abordagem territorial das políticas públicas que consistiria em considerar as especificidades das localidades, abandonando assim pacotes de políticas pré-formatados sem aderência às reais necessidades da realidade foco da ação. Todavia, Miranda e Silva expõem que tais políticas possuem um viés setorial e acabam por perceber os territórios como repositórios de investimentos (MIRANDA e SILVA, 2013, p.445).

A adoção de uma abordagem territorial nas políticas públicas se justifica por quatro principais fatores identificados por Abramovay (2007). Segundo o autor, tal abordagem possibilita o abandono de uma visão setorial na medida em que é percebida a existência de atividades não agrícolas e a "ruralidade, por aí, torna-se uma categoria territorial, cujo atributo decisivo está na organização de seus ecossistemas, na densidade demográfica relativamente baixa, na sociabilidade de interconhecimento e na dependência com relação às cidades" (ABRAMOVAY, 2007, p.19). O segundo fator a ser destacado é que a noção do território possibilita limitar melhor as diferenças entre crescimento econômico e processos de desenvolvimento, este necessariamente ocorre dentro de um escopo espacial e aqueles são apenas resultados de iniciativas envolvendo as atividades econômicas. Além disso, ressalta-se a importância dos estudos empíricos envolvendo os atores e suas respectivas organizações socioespaciais e, por último, a perspectiva territorial confere uma maior ênfase em como a sociedade utiliza os recursos de que dispõe através de sistemas sociais e ecológicos. 
Apesar de haver críticas quanto à abordagem territorial das políticas públicas em voga, cada vez mais ela tem sido justificada como necessária aos territórios rurais, pelo fato de possibilitar uma maior efetividade das intervenções públicas, já que considera os diversos elementos - espaciais, sociais e econômicos - que compõem a realidade sobre qual se pretende causar alguma alteração.

A abordagem territorial das políticas públicas de desenvolvimento dos territórios rurais tem o desafio de entender a diversidade de rurais que encontramos no Brasil. Como exposto, a modernização da agricultura ocasionou impactos sobre a vida das famílias que viviam nos territórios rurais, alterando também a forma, a estrutura e as funções ${ }^{10}$ dos espaços. Todavia não devemos identificar a modernização agrícola como único processo responsável pelas transformações dos espaços rurais. Cada território rural está submetido a contextos e contradições próprias, por isso respondem de forma diferenciada aos processos de desenvolvimento.

As contradições presentes nos territórios rurais, no entanto, não são estanques no tempo e também se inserem dentro do escopo de uma totalidade maior. Por isso, as mudanças observadas são decorrentes de diversos processos que estão inter-relacionados.

Neste sentido, as generalizações quanto às características dos rurais brasileiros com o intuito de reduzi-los a um único entendimento não são satisfatórias, já que os territórios rurais, a depender dos processos que são submetidos, apresentam identidades específicas que estão em uma constante evolução.

Com intuito de criar uma tipologia que não fosse reducionista e possibilitasse um entendimento global sobre as principais especificidades dos territórios rurais no que tange as suas articulações, Miranda e Silva (2013) elaboraram a tipologia da tabela a seguir que leva em consideração as dinâmicas regionais no que diz respeito aos fatores econômicos da atividade agrícola e a capacidade de articulação entre os territórios a fim de potencializar as oportunidades.

\footnotetext{
${ }^{10}$ Segundo Milton Santos a forma diz respeito àquilo que se apresenta visível nos espaços e retratam um arranjo de objetos sob um determinado padrão. A função dá sentido ao estabelecimento da forma, já que é através da função que podemos perceber a que se propôs a constituição do espaço. A estrutura, por sua vez, se refere à "inter-relação de todas as partes de um todo" (SANTOS, 1985, p.50), sendo assim estará intimamente relacionada com o modo de organização social.
} 


\section{Quadro 1 - Tipologia das regiões rurais}

\begin{tabular}{|c|l|}
\hline Tipo 1 & $\begin{array}{l}\text { Situações regionais que tendem a articular um bom desempenho da agricultura familiar } \\
\text { com um diversificado e flexível entorno socioeconômico. Nesse caso, a gradual redução } \\
\text { de necessidades de trabalho na agricultura tende a ser compensada pela criação local de } \\
\text { oportunidades de trabalho não agrícolas (tanto rurais quanto urbanas). }\end{array}$ \\
\hline Tipo 2 & $\begin{array}{l}\text { Situações regionais que tendem a combinar a afirmação de uma agricultura patronal com } \\
\text { um entorno socioeconômico absorvedor de mão de obra, isto é, gerador de oportunidades } \\
\text { de trabalho não agrícola (rurais e urbanas). Neste caso, uma franja periférica da } \\
\text { agricultura sobrevive essencialmente mediante a venda de braços dentro e fora da } \\
\text { agricultura. }\end{array}$ \\
\hline Tipo 3 & $\begin{array}{l}\text { Situações regionais que tendem a combinar o marasmo da agricultura (familiar ou } \\
\text { patronal) a um entorno socioeconômico incapaz de absorver os excedentes populacionais } \\
\text { das áreas rurais. }\end{array}$ \\
\hline Tipo 4 & $\begin{array}{l}\text { Situações de esvaziamento populacional que tendem a combinar sistemas produtivos bem } \\
\text { extensivos (em geral pecuária) com um entorno socioeconômico rígido e poupador de } \\
\text { mão de obra. }\end{array}$ \\
\hline Tipo 5 & $\begin{array}{l}\text { Situações nas quais a ocupação territorial é tão recente e a precariedade ou insipiência do } \\
\text { entorno socioeconômico é tão grande que ainda não estão definidas as chances de } \\
\text { viabilização de um dos quatro padrões anteriores. }\end{array}$ \\
\hline Tipo 6 & $\begin{array}{l}\text { Situações de tanta fragilidade - dos ecossistemas e do entorno - que impedem a } \\
\text { intensificação das práticas agrícolas, bloqueando ao mesmo tempo a geração de } \\
\text { oportunidades de trabalho não agrícola. }\end{array}$ \\
\hline
\end{tabular}

Fonte: Miranda e Silva, 2013.

O panorama aqui exposto sobre os significados do rural brasileiro auxilia na compreensão sobre uma abordagem diferenciada de políticas públicas de desenvolvimento territorial rural. $\mathrm{O}$ entendimento das transformações do rural permite que seja feita uma análise mais crítica sobre as políticas públicas constituídas para provocar mudanças sobre a realidade desses espaços.

A literatura que aborda a temática das políticas públicas no meio rural tem adjetivado o desenvolvimento de diferentes formas com o intuito de enfatizar determinado aspecto das ações que são articulas com o propósito de orientar projetos de longo prazo para o rural. A presente pesquisa recorrerá às contribuições dos autores que buscam adotar o conceito de desenvolvimento rural em seus estudos e de autores que enfatizam a abordagem territorial do desenvolvimento rural (ABRAMOVAY, 2009; FAVARETO, 2006; NAVARRO, 2001; SABOURIN, 2008; SCHNEIDER, 2004; VEIGA, 2001).

Para Navarro (2001) o desenvolvimento rural é compreendido como "uma ação previamente articulada que induz (ou pretende induzir) mudanças em um determinado ambiente rural" (p.88). Segundo o autor o Estado teria a capacidade de conduzir este processo por possuir legitimidade política e ser dotado de estrutura e mecanismos capazes de viabilizar o desenvolvimento. Neste sentido, através dos programas e projetos que atuam sobre a mudança da realidade do mundo rural, poderíamos identificar os modelos e estratégias que visam elevar a qualidade de vida das populações rurais. 
Por sua vez, Veiga (2001) opta por enfatizar a importância das dimensões ambientais e territoriais e a relevância da interconexão rural/urbano nas questões de desenvolvimento. E por isso aponta a necessidade de elementos fundamentais que devem estar presentes nas ações de desenvolvimento dos territórios rurais, sendo eles: fortalecimento da agricultura familiar, diversificação das economias territoriais, estímulo ao empreendedorismo local e a formação de arranjos institucionais locais impulsionados pelo Estado.

Ao analisar os estudos teóricos que debatem a delimitação dos significados do desenvolvimento rural, Schneider (2004) identifica quatro elementos-chave, sendo eles: erradicação da pobreza rural, o protagonismo dos atores sociais e sua participação política, o território como unidade de referência e a preocupação central com a sustentabilidade ambiental. Segundo o autor, os estudos têm se focado na participação dos atores e nas implicações das redes para a criação de um ambiente favorável ao desenvolvimento. Além disso, o território ganha relevância central porque passa a ser considerado como uma unidade de análise ideal para compreender os processos gerais de reestruturação societários e seus impactos locais. O enfoque dado ao território ganhou força após o reconhecimento da existência de um novo rural que deve ser entendido pela sua complexidade.

$\mathrm{O}$ consenso quanto à necessidade de expandir a visão sobre os significados dos espaços rurais, pode ser explicado de certa maneira pela constatação da ineficácia das políticas públicas orientadas por uma perspectiva estritamente agrária - de um determinado agrário - e com um viés setorial que pouco contribui para a promoção de um desenvolvimento equilibrado e sustentável.

As intervenções públicas devem agregar em suas concepções o aspecto espacial da problemática que procuram modificar. Deve-se considerar que a materialização das inciativas do poder público ocorrerá em territórios que possuem uma constituição dada pelas interações de diferentes atores em um processo temporal que sofre influência de diferentes dinâmicas, sociais, econômicas e ambientais. Assim sendo, as estratégias de desenvolvimento para serem efetivas precisam abarcar variadas dimensões.

A abordagem territorial do desenvolvimento permitiria romper com a barreia da setorialidade ao adaptar as intervenções às características territoriais. Neste sentido, deve-se pontuar a importância das relações sociais para o entendimento dos diferentes contextos territoriais que encontramos em nosso país. Os laços firmados entre os atores pertencentes a um território interferem em grande medida sobre a constituição deste e, além disso, ditam sobre a forma como vão ser usados os fatores imateriais e materiais disponíveis, os quais são 
fundamentais para a condução do processo de desenvolvimento. Os atores a serem considerados dentro de um território abrangem tanto os indivíduos isolados quanto as associações comunitárias e os setores público e privado. Neste contexto, torna-se relevante o entendimento acerca do que consistem as relações constituídas entre esses atores para que seja possível compreender de forma mais profunda a dinâmica territorial.

Embora a análise do território a partir de uma perspectiva sociológica a fim de ressaltar as relações sociais seja de grande relevância, os estudos e iniciativas de políticas públicas têm se concentrado no aspecto normativo do que o território deveria ser e são carentes de uma teoria da interação social (ABRAMOVAY, 2007).

A ótica normativa tende fazer comparações entre os territórios a fim de identificar os elementos que são essenciais para determinar um suposto padrão de condições necessárias para garantir o bom andamento de políticas que tenham como foco a melhoria das condições de vida. O problema desta perspectiva esta em determinar o que deveria ou não existir, ignorando assim os contextos de cada território. Por julgar haver uma relação de causa e efeito nas dinâmicas de um sistema territorial, desconsideram diversos fatores que interferem sobre uma dada localidade, que são decorrentes de diversos processos, sociais, históricos, culturais, internos e externos (ABRAMOVAY, 2007).

Neste sentido, os estudos que tem como o foco os territórios rurais devem considerar as relações constituídas entre os atores através de uma perspectiva que valorize a singularidade da realidade territorial com que o pesquisador se depara.

Dessa forma, comparações para determinar níveis de desenvolvimento são temerárias porque podem reduzir a complexidade da realidade encontrada. Tentar encaixar os territórios em modelos que pouco pode contribuir para o entendimento dos diversos processos sobre o qual um dado território está submetido. Sendo assim, antes de se procurar identificar o que deveria existir num dado contexto territorial, usando como referência um padrão exterior, é preciso entender a realidade por ela mesma, isso também vale para os aspectos que vão além da interação dos atores do território.

Neste sentido, as políticas públicas que buscam melhorar a qualidade de vida das famílias que vivem nos espaços rurais necessitam ser estruturadas dentro de uma institucionalidade própria que proporcione a efetividade e operacionalização dos princípios difundidos pelo desenvolvimento rural corrente.

Todavia, Favareto (2006) ao estudar as políticas públicas de desenvolvimento rural na América Latina, aponta que não houve ainda uma mudança significativa no contexto 
institucional das políticas públicas e assim percebe que "a 'nova visão' do desenvolvimento rural se instituiu com força suficiente para reorientar o discurso e o desenho das políticas e programas formulados com este fim, mas isto não se fez acompanhado da criação de instituições capazes de sustentar este novo caminho" (FAVARETO, 2006, p. 132).

As debilidades das instituições criadas para dar suporte às políticas públicas que carregam os princípios de uma nova compreensão sobre o rural estão relacionadas com a ausência de mecanismos que permitam uma efetiva apropriação dos projetos por parte dos agentes do território.

É possível encontrar no discurso político que orienta a elaboração dessas políticas a compreensão de que o "desenvolvimento territorial seria o resultado da interação entre dinâmicas locais produtivas, sociais e dinâmicas institucionais" (SABOURIN, 2009, p. 154). Todavia o componente que envolve a participação das estruturas governamentais criadas ou já presentes nos territórios na materialização das políticas de desenvolvimento rural é sobremodo valorizado em detrimento do reconhecimento das potencialidades locais e da capacidade dos atores locais de conduzirem as ações que impactarão diretamente sobre o contexto socioespacial do qual fazem parte.

Dessa forma, é observado que os recortes territoriais definidos para orientar a implementação dos projetos governamentais não consideram de maneira adequada as dinâmicas produtivas locais e fatores socioculturais do território. Como consequência, em certas situações há uma redução na eficácia das políticas formatadas para o rural e uma concorrência entre os interesses dos agentes locais e das instâncias governamentais superiores.

Logo, um real desenvolvimento territorial rural depende de uma adequada compreensão sobre os significados dos rurais que existem no Brasil. Tal compreensão considera as características socioespaciais de cada território e a complexidade das relações constituídas entre diversos atores. Isto possibilita que as intervenções públicas atuem de forma a potencializar os atributos de cada contexto socioespacial, com vistas à promoção do desenvolvimento. 


\subsection{A Emater- DF no contexto de políticas públicas para o rural Brasileiro}

A compreensão acerca da estrutura da política de Assistência Técnica e Extensão Rural - Ater juntamente com um resgate do histórico da Emater-DF, auxiliam a análise da inserção desta instituição dentro do contexto de políticas públicas de desenvolvimento rural.

Os serviços de Ater se originaram no país nos finais da década de 1940, mas se consolidaram institucionalmente dentro da estrutura de governo no momento da modernização agrícola. Com objetivo de analisar a trajetória dos serviços de assistência técnica, Rodrigues (apud DIAS, 2007) identifica três fases em que encontramos propósitos e princípios distintos no que tange a promoção destes serviços aos agricultores. Na primeira fase, compreendendo o período de 1948 a 1962, a assistência técnica rural é reconhecida pelo Estado como um serviço essencial para o campo, devendo ser garantida ao sua promoção por ser um serviço público de educação informal.

A segunda fase abrange os anos de 1963 a 1983 e se sobrepõe aos processos de intensificação da modernização do campo. Neste período a Ater se consolida dentro da estrutura governamental e se alinha a estratégia de desenvolvimento nacional da época. A promoção dos serviços de Ater tornou-se importante para garantir a incorporação pelos agricultores do pacote tecnológico da Revolução Verde. A Ater deste período é chamada de “difusionismo produtivista", Dias (2007) entende que ela "passa a integrar um sistema público voltado a um fim claro (modernizar o campo) e torna coerente e institucional um perfil profissional que é adotado de norte a sul na formação de estudantes de ciências agrárias: um agente moldado para o controle e para a intervenção instrumental sobre a natureza e a sociedade" (DIAS, 2007, p. 13). Com o intuito de coordenar as empresas espalhadas em todo o território de maneira tal que garantisse uma coerência entre as ações e assim alcançar os resultados pretendidos à época, em 1970 foi instituído o Sistema Brasileiro de Assistência Técnica e Extensão Rural - Sibrater. O Sibrater era um sistema descentralizado que tinha como coordenação nacional a Empresa Brasileira de Assistência Técnica e Extensão Rural (Embrater) e a execução ocorria por meio das empresas de Ater localizadas nos estados.

Em meados da década de 1980, alguns fatores impulsionaram as discussões sobre os rumos que a Ater deveria tomar, dentre os quais estão: a constatação dos custos sociais e ambientais decorrentes da modernização agrícola e o processo de redemocratização do país. Dias (2007) identifica que a partir desta década inicia-se a terceira fase dos serviços de Ater, denominada de "humanismo crítico", compreendendo mais especificamente os anos entre 1985 e 1989. Naquele momento, uma parcela dos extensionistas passou a compreender que 
um novo modelo de Ater deveria ser adotado, no qual as antigas práticas e concepções atreladas à modernização agrícola seriam superadas de forma a abrir espaço para compreensão de que o rural está além de uma visão produtivista. Neste sentido, observa-se uma maior aproximação com os movimentos sociais do campo e com os pequenos produtores.

Todavia a crise financeira do Estado, que se agrava no início dos anos 1990, e a retração na prestação dos serviços públicos, característica do novo modelo de governo que se implantara, impactaram sobre a estrutura dos serviços de Ater de todo o país. E assim, devido ao contexto econômico e político, o governo Collor de Mello em 1990 decidiu pela extinção do Sibrater o que provocou uma desestruturação dos serviços de Ater de muitas empresas estaduais que dependiam grandemente das transferências de recursos da esfera nacional.

A partir de então, os serviços de Ater tiveram que recorrer ao apoio dos governos estaduais e municipais para poder dar continuidade as suas atividades. Contudo, muitas empresas prestadoras destes serviços tiveram que encerrar suas atividades porque não conseguiram obter o apoio necessário através de outras instâncias de governo. Somente no início dos anos 2000 é que os serviços de Ater conseguem entrar novamente na agenda de governo e ser fortalecido politicamente.

A retomada da Ater foi proporcionada através de um novo contexto de governo que era favorável à participação de diferentes setores da sociedade civil organizada na formulação da política. Sendo assim, a atual "Política Nacional de Ater foi construída de forma participativa, em articulação com diversas esferas do governo federal, ouvindo os governos das unidades federativas e suas instituições, assim como os segmentos da sociedade civil, lideranças das organizações de representação dos agricultores familiares e dos movimentos sociais comprometidos com esta questão" (BRASIL, 2007).

A política de Ater conseguiu ganhar maior importância dentro das políticas públicas de desenvolvimento rural do governo quando em 2003 o decreto $n^{\circ} 4.739$ atribuiu ao Ministério do Desenvolvimento Agrário a competência para conduzir tal política. A partir de então os serviços de Ater ganharam um sentido renovado e têm se consolidado no país como uma ferramenta necessária para melhorar as condições de vida das populações rurais. Agora os serviços de Ater são orientados pelo compartilhamento de técnicas com os agricultores, considerando fatores socioambientais e culturais da realidade local.

Embora a Constituição Federal de 1988 e a Lei Agrícola de 1991 tenham imputado à União a responsabilidade de promover serviços de Ater pública e gratuita aos pequenos produtores, somente com a transferência da competência relativa à assistência técnica e 
extensão rural para o MDA é que tal serviço de fato passou a existir como auxiliador das ações de desenvolvimento rural. Isto porque o ministério anteriormente responsável pelo setor, o Ministério da Agricultura Pecuária e Abastecimento, não havia desenvolvido ações estruturantes, decorrendo assim a ausência de políticas de promoção à Ater no período anterior.

A atual política de Ater também foi influenciada, assim como a abordagem corrente de políticas públicas para o rural, pela constatação dos impactos negativos do modelo de agricultura moderna estimulado pelas políticas da segunda metade do século XX. Dessa forma, preza pelo estímulo a um desenvolvimento sustentável no meio rural que fomente a transição agroecológica, considere as especificidades dos diferentes agroecossistemas e os diversos contextos socieconômicos e culturais do nosso país.

Em um primeiro momento os serviços de Ater foram organizados de forma descentralizada através do Sistema Nacional de Descentralizado de Ater Pública, onde o Departamento de Assistência Técnica e Extensão Rural - Dater da Secretaria de Agricultura Familiar do MDA era responsável pela coordenação. Contudo, recentemente, em maio de 2014 através do Decreto n ${ }^{\circ} 8.252$ foi instituída a Agência Nacional de Assistência Técnica e Extensão Rural - Anater que será responsável por coordenar a política de Ater, mantendo a gestão descentralizada da execução da política.

As agências públicas e privadas, desde que estejam de acordo com os princípios da política, podem se credenciar para executar os serviços de Ater nas diferentes localidades do país. Neste sentido, a política pressupõe a necessidade de formação de uma rede composta por diversos atores que atuarão em prol da construção de ações que atendam às necessidades das populações rurais de modo a promover um desenvolvimento rural sustentável.

Os agentes de Ater passam a desempenhar o papel de serem facilitadores do processo de apropriação de técnicas que possibilitem o desenvolvimento de sistemas agrícolas sustentáveis, "adotando metodologias participativas e uma pedagogia construtivista e humanista, tendo sempre como ponto de partida a realidade e o conhecimento local" (BRASIL, 2007), neste sentido “deverão ser privilegiadas atividades de pesquisa-ação participativas, investigação-ação participante e outras metodologias e técnicas que contemplem o protagonismo dos beneficiários e o papel de agricultores-experimentadores" (BRASIL, 2007). 
Os públicos atendidos pelos serviços de Ater são: agricultores familiares, silvicultores, aquicultores, extrativistas, pescadores, assentados da reforma agrária, povos indígenas, remanescentes de quilombos e demais povos e comunidades tradicionais.

Os serviços de Ater são orientados pelas seguintes princípios e objetivos dispostos na Lei $12.188 / 2010$ que instituiu a Pnater:

\section{Quadro 2 - Princípios e objetivos da Lei 12.188/2010}

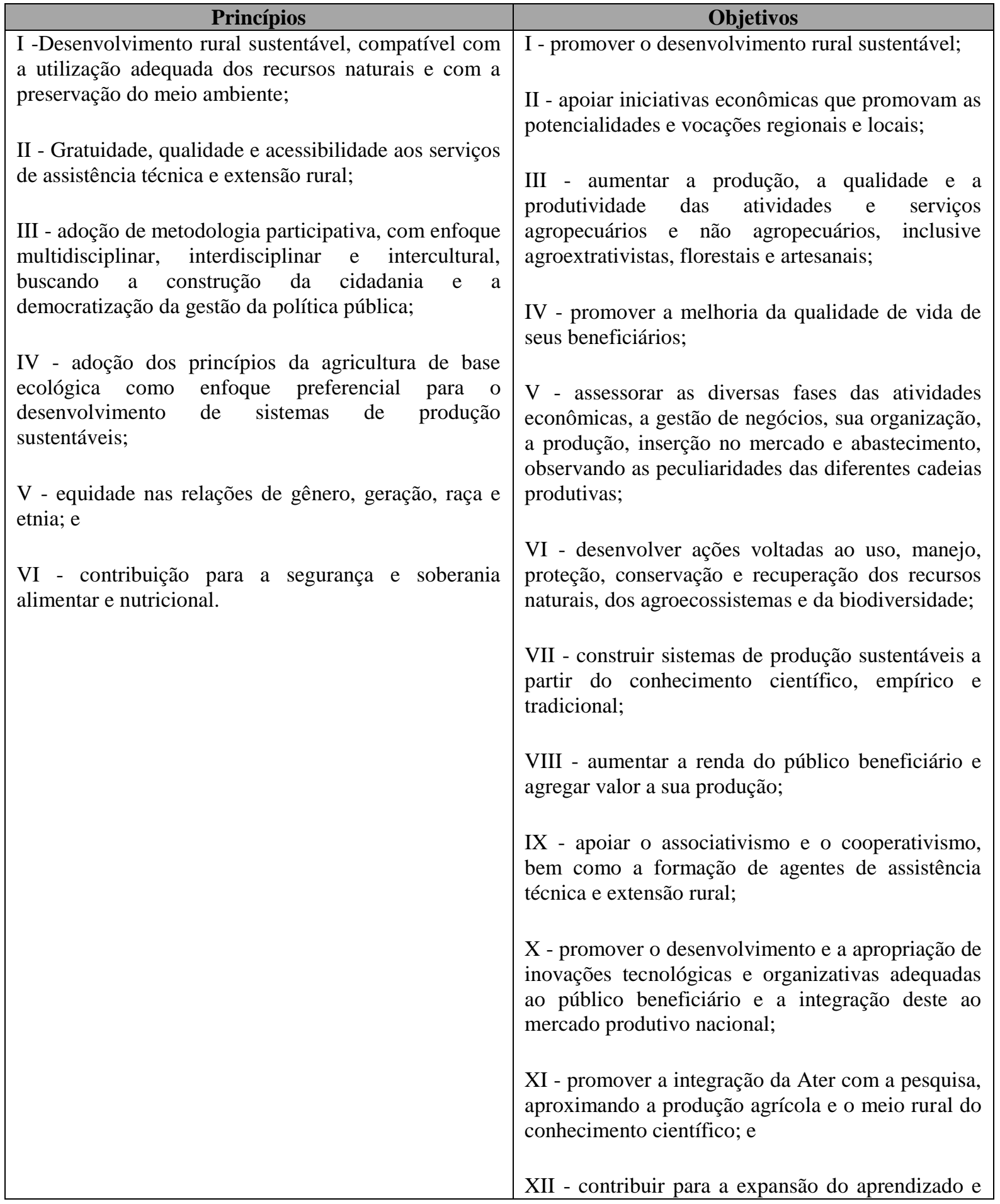




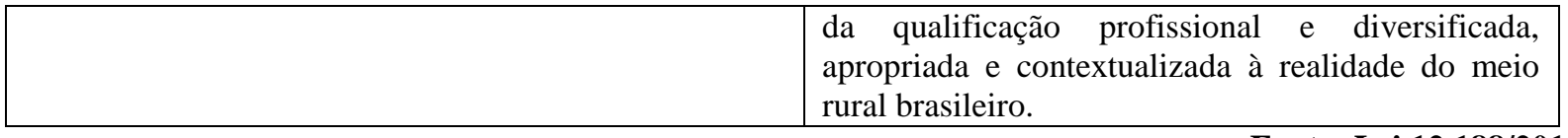

Fonte: Lei 12.188/2010

A história da Emater-DF se mescla com desenvolvimento da política de Ater a nível federal. Os momentos de evolução e inflexão da política estruturada para o país como um todo afetam as ações da Emater-DF em seu contexto local. Além disso, também foram fatores de influência sobre os serviços de Ater na capital federal os interesses políticos relacionados com a modernização agrícola do Cerrado e com a garantia de oferta de alimentos ao centro urbano da nova capital.

A Emater-DF se originou em um contexto onde diversas políticas estavam sendo propostas para desenvolver os núcleos rurais pertencentes a área de abrangência da nova capital com a finalidade de aumentar a produção agropecuária e superar os problemas de abastecimento que se apresentavam à época.

Uma das primeiras medidas a serem tomadas foi a modificação do padrão de arrendamento das terras rurais que passou a exigir o plano de utilização da área e a comprovação da capacidade econômica por parte do arrendatário. Em seguida, por meio da Fundação Zoobotânica do Distrito Federal (FZDF), órgão já extinto, foi estabelecida a vocação produtiva de núcleos rurais que passaram a se dedicar a produção de determinados gêneros, com especial destaque para as hortaliças, frutas, grãos e pecuária. Além disso, também houve uma maior disponibilização de linhas de crédito para os produtores rurais do DF através do Banco do Brasil. Outra política relevante a ser destaca no período foi a criação do Programa de Assentamento Dirigido do Distrito Federal (PAD-DF) que tinha o intuito de estimular a ocupação das terras pertencentes ao governo do Distrito Federal com uma atividade agropecuária de alto padrão tecnológico.

Em 1978 a Emater-DF foi instituída com "o objetivo de planejar, coordenar e executar programas de assistência técnica, econômica e social, para o aumento da produção e da produtividade agropecuária e a melhoria das condições de vida do homem no meio rural" (Emater, 2008, p.32). Naquele momento a empresa contava com o apoio da Embrater e da Embrapa para a execução de suas atividades que tinham o propósito de dar suporte ao desenvolvimento da agropecuária da região do Cerrado, fazendo do DF um multiplicador das técnicas agropecuárias até então empregadas.

Conforme a empresa foi se estruturando os focos de atuação foram aumentando para além da atividade agropecuária, e assim foram desenvolvidas ações iniciais de organização 
sócio-rural, incentivo à produção de alimentos básicos destinados ao consumo da região e ações de capacitação dos produtores rurais.

A promulgação da Constituição Federal de 1988 foi responsável por dar um impulso à apropriação de um novo significado em relação aos propósitos da assistência técnica e extensão rural. A partir deste marco legal a Ater no DF deixaria de ser reconhecida apenas como necessária para o aumento da produtividade por meio do estímulo à técnicas agrícolas mais sofisticadas, mas também seria compreendido o seu papel relevante nas questões sociais e de organização sócio-produtiva no campo. Assim sendo "a visão meramente difusionista cedeu espaço às necessidades dos produtores, trabalhadores rurais e suas famílias, adotandose o planejamento participativo e propondo-se um padrão de desenvolvimento como resultado do processo de decisão dos atores envolvidos" (EMATER, 2008, p. 36).

A crise econômica do final da década de 1980 que provocou a redução dos gastos com serviços públicos, atingido severamente os serviços de Ater, afetou, como as demais empresas do setor, a Emater-DF que teve que fechar 4 escritórios naquele período. Todavia, no início dos anos 1990, o apoio do Governo do Distrito Federal através de transferências de recursos financeiros e a realização de convênios com organismos internacionais foram determinantes para manutenção e expansão das atividades da Emater-DF.

A partir dos anos 2000 houve um novo contexto institucional para as políticas de desenvolvimento rural do Estado Brasileiro. Criaram-se órgãos e estruturas específicas na esfera federal com o propósito de fortalecer a agricultura familiar. Este novo contexto institucional acabou por influenciar também as ações da Emater-DF.

Um novo aporte de recursos e diretrizes quanto aos componentes fundamentais das políticas de apoio aos agricultores, concebidos pelo governo federal, têm estimulado nos últimos anos o desenvolvimento de um olhar diferenciado sobre a agricultura familiar. Neste sentido, a Emater-DF começou a desenvolver ações complementares que promovem a melhoria da qualidade de vida das populações rurais e, assim "fortaleceu ainda mais suas iniciativas com ações comunitárias, promovendo o acesso da população carente da área rural aos serviços sociais e assistenciais nas áreas de saúde, previdência, educação, saneamento, higiene, direito civil, extensão rural, meio ambiente e lazer, além de formação técnica e de cidadania" (EMATER, 2008, p.47).

Neste contexto, a Pnater induziu a valorização da promoção de técnicas agrícolas sustentáveis com reduzidos impactos ambientais e sociais e que consideram o protagonismo dos atores sociais. Neste sentido, atualmente a Emater-DF apresenta como missão "Promover 
o desenvolvimento rural sustentável e a segurança alimentar, por meio de Assistência Técnica e Extensão Rural de excelência, em benefício da sociedade do Distrito Federal e Entorno", e ainda tem como visão: "Ser reconhecida pela sociedade na promoção do desenvolvimento rural sustentável e da segurança alimentar" ${ }^{11}$.

Com a finalidade de ofertar um atendimento abrangente no DF e na região do entorno, a Emater-DF possui 15 gerências locais no DF: Alexandre de Gusmão, Brazlândia, Ceilândia, Gama, Jardim, PAD-DF, Paranoá, Pipiripau, Planaltina, Rio Preto, São Sebastião, Sobradinho, Tabatinga, Taquara e Vargem Bonita; e 8 gerências locais na região do retorno da capital em Goiás: Água Fria de Goiás, Cabeceiras, Cocalzinho de Goiás, Cristalina, Formosa, Padre Bernardo, Planaltina e Vila Boa. Também conta com Escritório Central e um Centro de Treinamento.

A empresa estrutura suas ações dentro de oito programas prioritários: Programa Gestão Ambiental, Programa Floricultura, Programa de Olericultura, Programa de Organização e Gestão Social, Programa do Leite, Agricultura Urbana, Programa de Piscicultura e Programa Agreoecologia, sendo o último objeto desta pesquisa e será melhor detalhado na subseção seguinte.

Atualmente a empresa atende mais de $90 \%$ dos agricultores familiares do Distrito Federal e presta atendimento a todos os Assentamentos de Reforma Agrária da região. No Distrito Federal 46\% dos estabelecimentos agrícolas são do segmento da agricultura familiar, contudo a estrutura fundiária ainda é concentrada, já que eles representam apenas 4,3\% da área total destinada à produção de gêneros agrícolas, como demonstra a tabela a seguir:

Tabela 2 - Número e área total dos estabelecimentos, compreendidos pela modalidade de agricultura familiar e não familiar - Distrito Federal

\begin{tabular}{|c|c|c|c|c|}
\hline & Estabelecimentos (no) & Percentual (\%) & Área (ha) & Percentual (\%) \\
\hline Familiar & 1.824 & 46,1 & 10.867 & 4,39 \\
\hline Não familiar & 2.131 & 53,9 & 240.453 & 95,61 \\
\hline Total & 3.955 & 100 & 251.478 & 100 \\
\hline
\end{tabular}

Como exposto, a Emater-DF teve um papel significativo no apoio às políticas que visavam estimular à produção agrícola com a intenção de possibilitar o abastecimento de alimentos à capital nascente. No momento, a empresa persegue o desafio maior de proporcionar um serviço de Ater que efetivamente promova um desenvolvimento rural

\footnotetext{
${ }^{11}$ Disponível em:

<http://www.emater.df.gov.br/index.php?option=com_content\&view=article\&id=47\&ltemid=60>
} 
sustentável e que para tanto incorpore os princípios correntes das políticas para este setor presentes em normativas das instituições públicas, nas pautas de reivindicações dos movimentos sociais e nos estudos de teóricos que analisam a temática no caso brasileiro.

O estímulo à agroecologia como um meio para a promoção do desenvolvimento sustentável é um dos objetivos da empresa. Contudo, devemos apontar que modificar os padrões produtivos no DF não é uma tarefa fácil. Um estudo recente da Companhia de Planejamento do Distrito Federal - Codeplan sobre a agricultura familiar no Distrito Federal constatou que houve um aumento constate no uso de agrotóxicos no período compreendido entre 2000 a 2011. O aumento neste período foi do montante de $119,15 \%$, ou seja, um consumo que era de 830 toneladas passou para 2.483 toneladas (CONDEPLAN, 2015a). Sendo assim, torna-se mais que oportuno, para redução dos custos ambientais e sociais, que a Ater no Distrito Federal consiga exercer interferência por meio agroecologia nos modelos produtivos adotados pelos agricultores da região da capital.

\section{Gráfico 1 - Quantidade em toneladas do consumo de agrotóxico no Distrito Federal}

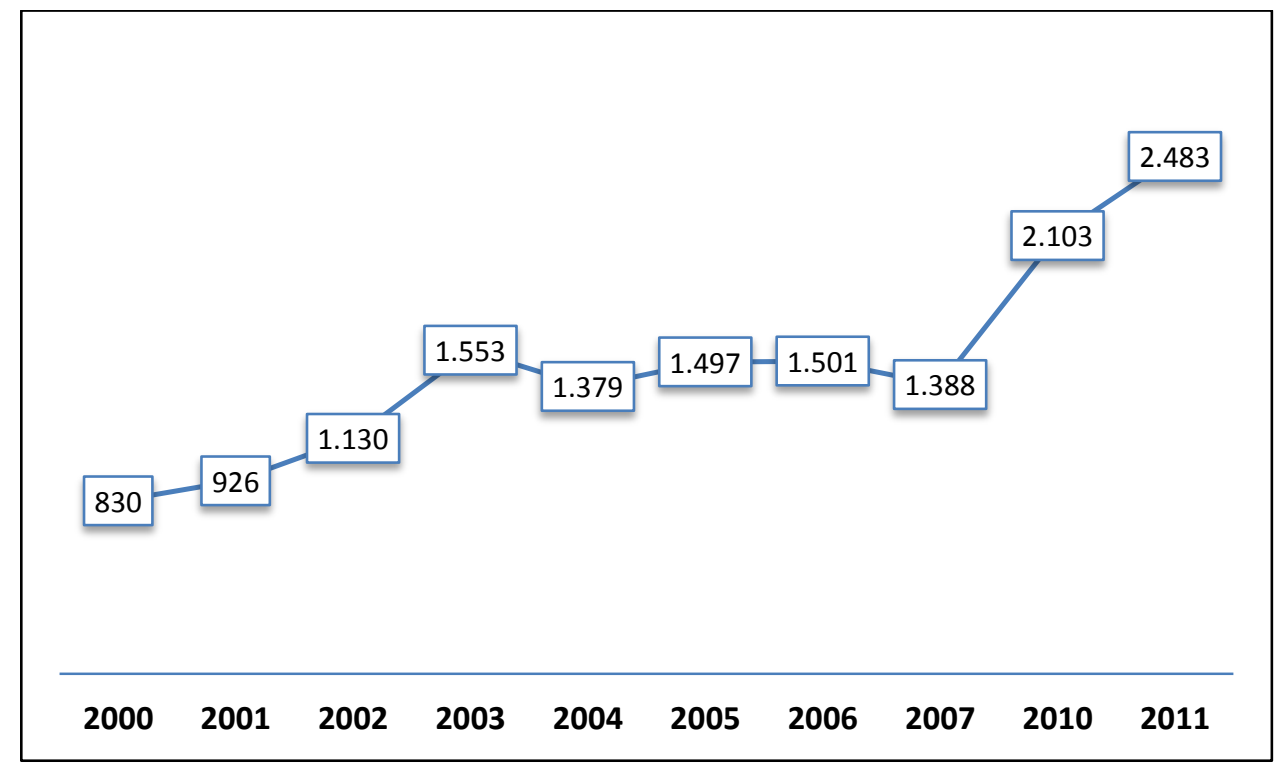

Fonte: Codeplan, 2015a

\subsection{O Programa de Agroecologia da Emater-DF e as suas especificidades em Brazlândia}

O programa de Agroecologia da Emater-DF é entendido como uma política pública que busca trazer um desenvolvimento territorial rural mais sustentável para as localidades foco de suas ações. Uma compreensão mais aprofundada sobre a estrutura do programa, os 
propósitos para o qual foi constituído e sua capacidade de interferência sobre o contexto territorial, pode ser viabilizada através de instrumentos próprios do campo de conhecimento das políticas públicas.

A presente pesquisa adota nesta seção os instrumentos e técnicas do campo de conhecimento das políticas públicas que, quando empregados, permitem transparecer as intencionalidades do poder público na constituição de planos, programas e projetos, bem como identificar os resultados e impactos que se pretende atingir com o intuito de modificar uma dada realidade.

As ações públicas se estruturam, sobretudo, com a finalidade de resolver problemas públicos. É possível identificar no campo das políticas públicas duas correntes que têm o propósito de entender como se dá a atuação das instituições públicas na resolução dos problemas públicos, sendo elas: a análise de políticas públicas e a avaliação de políticas públicas. A análise de políticas públicas consiste na compreensão da engenharia institucional que implica na determinação do desenho de um programa, já a avaliação de políticas públicas permite estabelecer uma relação de causalidade entre um programa e um resultado que afeta a realidade social (Arretche, 1998).

O contexto institucional sobre o qual o Programa Agreocologia, aspecto enfatizado nos estudos que têm como foco a análise de políticas públicas, foi parcialmente abordado na seção anterior. Como foi exposto, a Emater-DF sofre influências da corrente abordagem de políticas públicas para o rural. Além disso, as políticas para os serviços de Ater pública do país, gestadas no governo federal, têm difundido diretrizes que prezam pela valorização da agricultura familiar e pelo incentivo de práticas agrícolas sustentáveis.

No transcorrer desta seção nos focaremos na aplicação das técnicas utilizadas pela avaliação de políticas públicas para compreender os componentes constitutivos de um programa e as relações de causalidade entre as ações propostas, com o intuito de verificar as intencionalidades que os agentes públicos têm em relação a uma dada problemática social. É importante ressaltar que a pesquisa não pretendeu realizar uma avaliação do Programa Agroecologia, apenas adotar alguns aspectos conceituais do campo de conhecimento da avaliação de políticas públicas com a finalidade de entender a lógica de atuação do poder público através do programa em questão.

Dado o propósito de entender o funcionamento do programa a partir dos mecanismos, relações causais entre seus componentes e os processos estabelecidos, de forma 
a transparecer a realidade sobre qual o programa é operado, serão adotados termos próprios da tipologia da avaliação de implementação.

A Teoria do Programa ou o Modelo Lógico do Programa é um conceito desenvolvido dentro da área de avaliação de políticas públicas e permite evidenciar a relação existente entre as iniciativas desenvolvidas e os objetivos traçados para atingir a mudança desejada em um determinado contexto. Dessa forma, é possível identificar a relação causal entre os inputs e os objetivos pretendidos pela intervenção do poder público. O intuito principal é entender os princípios teóricos sobre o qual o programa baseia a constituição de suas ações.

Com intuito de transparecer a teoria do Programa Agroecologia da Emater DF, aplicaremos o modelo lógico desenvolvido pela W.K. Kellog Foundation (MERTENS \& WILSON, 2012), o qual possibilita perceber a complexidade do programa, explicar como os objetivos serão atingidos e entender o porquê de realizar determinadas ações. Segundo o modelo, é preciso que sejam identificados o problema, as necessidades e pontos fortes do público-alvo, os resultados desejados (outputs, outcomes e impactos), os fatores de influência, as estratégias e as suposições levantadas no momento de criação do programa.

O principal problema sobre o qual o programa agroecologia atua é o de promover o desenvolvimento rural sustentável na região do Distrito Federal. O problema só passou a ser considerado crítico ao ponto de entrar na agenda de ações da Emater-DF, devido aos estudos técnicos que apontam para os danos causados pela agricultura convencional ao meio ambiente e às pressões de movimento sociais. Estes fatores foram relevantes para o reconhecimento da necessidade de desenvolver ações que visem estimular práticas agrícolas mais sustentáveis.

O público-alvo do programa é composto por dois grupos de pequenos agricultores. O primeiro grupo de pequenos agricultores corresponde aos agricultores que já desenvolvem atividades produtivas por meio de sistemas de base agroecológica. Já o segundo grupo se refere aos agricultores que pretendem se inserir no processo de transição agroecológica e têm pouco conhecimento em relação às práticas agrícolas alternativas.

As necessidades identificadas nos agricultores que justificaram o desenvolvimento de um programa como este pela Emater-DF podem ser agrupadas em três dimensões: econômica, ambiental e prevenção contra intoxicações. As técnicas agrícolas convencionais exigem insumos de produção que provocam dependência produtiva e tornam os cultivos mais susceptíveis a pragas. Outro fator a ser mencionado dentro do escopo da dimensão econômica é a necessidade de entrar em nichos especiais de mercado, como o de produtos orgânicos, que possuem um valor de mercado mais atrativo. No Distrito Federal a produção orgânica tem um 
crescimento médio anual de $20 \%$ e estima-se que haja aproximadamente 40 mil consumidores destes produtos (CODEPLAN, 2015b).

Quanto aos pontos fortes, ou melhor, potencialidades do público atendido que contribuem para o bom desenvolvimento do programa, deve-se destacar o fato de parte deles possuir ligações com movimentos sociais de luta pela terra que em sua maior parte contribui para que a agroecologia seja difundida como um importante instrumento para garantia de um desenvolvimento sustentável. Além disso, na região de atuação da Emater-DF são identificados casos de agricultores convencionais que começaram a exercer uma agricultura alternativa, já tendo incorporando em suas práticas agrícolas os princípios da agroecologia.

Para definirmos os resultados desejados, entendidos pelo modelo lógico aqui adotado como sendo os outputs, outcomes e impactos, é preciso elencar os objetivos traçados para o programa, os quais auxiliam na compreensão destes elementos. Encontramos como objetivos do programa:

\section{Objetivo geral}

- Estimular e apoiar a transição de padrões convencionais de produção e desenvolvimento rural para modelos sustentáveis baseados em princípios agroecológicos.

\section{Objetivos específicos}

- Contribuir para a conservação do bioma cerrado.

- Promover o desenvolvimento da agroecologia no DF e entorno.

- Apoiar a ecologização e transição agroecológica de propriedades convencionais de economia familiar.

- Promover o desenvolvimento de sistemas de produção de base ecológica.

- Fomentar e apoiar a criação de canais de comercialização de produtos de base ecológica.

- Realizar atividades de capacitação de técnicos e agricultores.

- Estimular e apoiar iniciativas de melhoramento e adaptação genética de animais para sistemas de base ecológica.

- Estimular a meliponicultura.

- Estimular o trabalho de extensão rural agroecológica com os jovens e mulheres rurais.

- Estimular o associativismo e o cooperativismo entre produtores agroecológicos de economia familiar.

- Sistematizar e publicar experiências desenvolvidas a partir do enfoque agroecológico e disponibilizar material didático e promocional.

- Articular parcerias com instituições governamentais distritais, federais e organizações não governamentais.

- Colaborar na elaboração de políticas públicas de apoio à agricultura de base ecológica.

- Participar em órgãos colegiados distritais e federais ligados à agroecologia (Emater, 2010).

Ao analisarmos os objetivos específicos podemos enquadrá-los em cinco dimensões: conservação dos recursos naturais; disseminação da agroecologia entre os agricultores e 
técnicos extensionistas; fomento a sustentabilidade dos sistemas de produção de base agroecológica; apoio à comercialização de produtos agroecológicos e incentivo às formas colaborativas de produção; e estabelecimento de parcerias com diferentes instituições públicas e não governamentais. Além dessas dimensões, também percebemos que as ações devem ter uma especial atenção em relação ao público jovem e de mulheres.

Os outputs são os produtos ou serviços entregues, comumente derivados do processo operacional do programa, geralmente estão previstos em metas e são percebidos em uma dimensão temporal de curto prazo. Os outcomes, por sua vez, são a expressão do alcance dos objetivos e são identificados a partir das mudanças que se pretende fazer sobre a realidade foco da intervenção. Tanto os outputs como os outcomes têm sido mensurados pela instituição através de indicadores que estão indicados na tabela abaixo.

\section{Quadro 3 - Indicadores do Programa Agroecologia da Emater-DF}

\begin{tabular}{|c|c|}
\hline Indicador & $\begin{array}{c}\text { Tipologia do resultado } \\
\text { mensurado }\end{array}$ \\
\hline Público assistido $\left(\mathrm{n}^{\mathrm{o}}\right)$ & output \\
\hline Propriedades em transição agroecológica $\left(n^{\circ}\right)$ & output \\
\hline Propriedades agroecológicas (sistemas de base ecológica) $\left(\mathrm{n}^{\circ}\right)$ & output \\
\hline Área plantada de cultivos agroecológicos $-(\mathrm{Ha})$ & output \\
\hline Público capacitado $\left(\mathrm{n}^{\mathbf{o}}\right)$ & output \\
\hline Escolas rurais atendidas em educação ambiental e agroecologia $\left(n^{\circ}\right)$ & output \\
\hline Número de grupos de interesses criados ou fortalecidos $\left(\mathrm{n}^{\circ}\right)$ & output \\
\hline Atendimentos & output \\
\hline Extensionistas rurais da Emater-DF capacitados $\left(\mathrm{n}^{\circ}\right)$ & output \\
\hline Sistemas agroflorestais implantados $\left(\mathrm{n}^{\circ}\right)$ & output \\
\hline Quintais agroflorestais/multifuncionais manejados/implantados $\left(\mathrm{n}^{\mathbf{o}}\right)$ & output \\
\hline Plantio ou replantio de espécies do cerrado ( $\mathrm{n}^{\circ}$ mudas) & output \\
\hline Produção agroecológica (T) & outcome \\
\hline Renda bruta referente à produção orgânica no DF (R\$ milhões) & outcome \\
\hline Postos de venda de produtos de base ecológica ou orgânicos $\left(n^{\circ}\right)$ & outcome \\
\hline
\end{tabular}

Já os impactos são definidos como os efeitos que o programa proporciona não restritos ao escopo de atuação deste, porque podem atingir um nível mais macro, sendo percebidos em um longo espaço de tempo, podendo ser previstos ou não. Dentre os impactos esperados a Emater-DF pretende atingir os abaixo relacionados:

\section{Impactos esperados}

- Contribuição para a conservação do bioma Cerrado.

- Transição gradativa para um modelo sustentável de desenvolvimento rural.

- Contribuição para o aumento da área e da produção de sistemas de base ecológica.

- Aumento do número de agricultores orgânicos certificados. 
- Maior geração de ocupação, emprego e renda em comparação a sistemas convencionais.

- Ampliação dos canais de comercialização de produtos orgânicos e de base ecológica.

- Geração de tecnologias apropriadas e de base ecológica.

- Apropriação por produtores convencionais de práticas e técnicas agroecológicas.

- Maior número de técnicos e agricultores capacitados em agroecologia.

- Redução do uso de agroquímicos e dos impactos ambientais negativos.

- Maior número de propriedades rurais ambientalmente adequadas e com redução dos impactos ambientais negativos.

- Diminuição do assoreamento e contaminação dos cursos d'água.

- Melhoria da paisagem rural pelo incremento da biodiversidade produtiva e funcional.

- Redução da dependência dos agricultores em relação a insumos externos.

- Maior identificação dos jovens com sistemas agroecológicos e incentivo a sua permanência no meio rural.

- Contribuição para a formação de consumidores responsáveis sobre questões sócio-ambientais.

- Melhoria da qualidade de vida das famílias rurais.

- Maior segurança alimentar e nutricional da população rural e urbana (EmaterDF, 2010).

É preciso pontuar que alguns dos impactos esperados, definidos pela instituição, estão relacionados com os objetivos propostos, por isso seriam melhor classificados se estivessem dentro do escopo dos objetivos. Sendo assim, identificamos como impactos do Programa Agroecologia, ou seja, alterações em nível macro decorrentes da influência do programa, os seguintes: contribuição para a conservação do bioma Cerrado; transição gradativa para um modelo sustentável de desenvolvimento rural; maior geração de ocupação, emprego e renda em comparação a sistemas convencionais; diminuição do assoreamento e contaminação dos cursos d'água; melhoria da paisagem rural pelo incremento da biodiversidade produtiva e funcional; maior identificação dos jovens com sistemas agroecológicos e incentivo a sua permanência no meio rural; contribuição para a formação de consumidores responsáveis sobre questões sócio-ambientais; melhoria da qualidade de vida das famílias rurais; e maior segurança alimentar e nutricional da população rural e urbana.

No se refere aos fatores de influência do programa, ou seja, aquilo que não pode ser gerenciado pelo programa e contribui ou não para o alcance dos objetivos, podemos citar a Política Nacional de Agroecologia e Produção Orgânica - Pnapo, a crescente demanda por alimentos orgânicos e as transferências de recursos advindas de outras instâncias de governo e órgãos de apoio à agricultura familiar.

A Pnapo foi instituída em 2012 por meio do Decreto $n^{\circ} 7.794$ e tem como objetivo "integrar, articular e adequar políticas, programas e ações indutores da transição agroecológica, da produção orgânica e de base agroecológica, como contribuição para o desenvolvimento sustentável e a qualidade de vida da população, por meio do uso sustentável 
dos recursos naturais e da oferta e consumo de alimentos saudáveis". A partir da criação desta política tem sido criadas condições para o desenvolvimento de ações que possibilitem o fortalecimento da agricultura alternativa no país.

As estratégias ou atividades adotadas para proporcionar o alcance dos objetivos do programa têm sido: a promoção de cursos de difusão dos princípios da agroecologia direcionados aos agricultores; capacitação dos agentes de Ater; parceria com instituições governamentais e de ensino para realização de eventos e outras ações que fortaleçam o exercício das práticas agroecológicas, tais como produção de sementes agroecológicas para reduzir custos e aumentar a autonomia dos agricultores e oficinas técnicas de orientação para a preservação dos recursos naturais; e a realização a cada dois anos de Seminários de Agroecologia que têm proporcionado interações entre as instituições da área e os movimentos sociais.

Por fim, o modelo lógico aqui utilizado propõe que sejam levantadas as suposições que estão por de trás da concepção do programa. Ou seja, os princípios, crenças ou ideias que direcionam o programa e justificam o motivo de sua existência. Para tanto é necessário retomar alguns eventos e marcos legais que influenciaram a institucionalização desta política pela Emater-DF.

No início da década de 1990, as discussões gestadas na academia e nos movimentos sociais quanto aos danos da agricultura convencional ao meio ambiente e a sua insustentabilidade como atividade econômica de produção de alimentos começaram a ganhar espaço nas instituições públicas. Os governos passaram, então, a iniciar processos de formulação de políticas pública para o incentivo de práticas vinculadas à difusão de uma agricultura alternativa.

No Distrito Federal, o Seminário de Agricultura Alternativa realizado pelas Secretarias do Meio Ambiente e da Agricultura em 1995 marca o início da estruturação de ações coordenadas pelo poder público de incentivo a uma agricultura mais sustentável na região da Capital. Outro evento a ser destacado que corroborou para o surgimento de um ambiente favorável a implantação do Programa de Agroecologia, foi a criação em 2000 do Plano de Desenvolvimento Rural do Distrito Federal - PRÓ-RURAL/DF - RIDE que instituiu dentre os seus programas o Programa de Agricultura Orgânica.

Outros fatores externos ao governo do Distrito Federal, mas que tiveram influência sobre a criação do programa de Agroecologia, foi a Política Nacional de Assistência Técnica e Extensão Rural - Ater e a Lei $n^{\circ} 10.831 / 2003$ que dispõe sobre a agricultura orgânica. A 
Pnater tem entre os seus propósitos "estimular, animar e apoiar iniciativas de desenvolvimento rural sustentável, que envolvam atividades agrícolas e não agrícolas, pesqueiras, de extrativismo, e outras, tendo como centro o fortalecimento da agricultura familiar, visando à melhoria da qualidade de vida e adotando os princípios da Agroecologia como eixo orientador das ações" (MDA, 2007). A Lei de Agricultura Orgânica, por sua vez, iniciou um processo de construção de um aparato normativo sobre o exercício de práticas agrícolas sustentáveis.

Em 2014 foram atendidos 400 agricultores em ações de capacitação e acompanhamento individual na reestruturação da propriedade com vistas a incorporar um modelo de produção mais sustentável. Além disso, houve a participação de 858 inscritos no IV Seminário de Agroecologia do Distrito Federal e Entorno promovido pela Emater-DF.

O Programa Agroecologia procura induzir os princípios da agroecologia entre os técnicos extensionistas e os agricultores. Em relação ao desenvolvimento do programa, quando não existe projetos específicos direcionados aos agricultores, as ações de disseminação da agroecologia ficam mais restrita a capacitações, participação em eventos ou assistência técnica individual - nos casos em que o próprio agricultor demanda da instituição.

A execução do Programa depende em grande medida da articulação com outras instituições e da incorporação pelas gerências dos escritórios locais dos pressupostos do programa, de forma a promover adaptações aos contextos locais. A estrutura organizacional da Emater-DF confere aos escritório locais grande autonomia para que sejam desenhadas ações segundo as especificidades do público de agricultores de cada localidade. Sendo assim, a depender das características de atuação de cada escritório a política de Ater da Emater-DF terá um desenho específico que busca se adequar às características territoriais e necessidades produtivas dos agricultores.

Os resultados alcançados pelas diferentes ações são computados dentro do Programa Agroecologia, que se caracteriza mais como um programa guarda-chuva de diversas iniciativas, as quais nem sempre estão articuladas entre si. Uma coesão interna dentro do Programa Agroecologia através de ações devidamente articuladas de forma a causar uma impacto lógico sobre os diferentes territórios do contexto do Distrito Federal, depende que a Emater-DF aporte mais recursos a este programa, tanto financeiros quanto o aumento no número de extensionistas. A equipe do escritório central é bem reduzida, conta apenas com apenas três servidores e a execução dos projetos depende em grande medida do estabelecimento de parcerias entre instituições governamentais e instituições de ensino. 
Embora as ações diversas que buscam transmitir os princípios e conceitos da agroecologia possam em maior ou menor grau influenciar a relação dos agricultores com o cultivo da terra, a transitoriedade e a ausência de sinergia entre essas ações dificulta identificar a correlações entre as intervenções públicas e mudanças sobre os modelos produtivos dos agricultores. Neste sentido, analisar como a agroecologia tem sido difundida pela Emater-DF, de modo ao causar impactos sobre os territórios, depende da existência de uma ação com as seguintes características: duração em um recorte temporal, atendimento de um público bem definido e objetivos a serem perseguidos previamente definidos.

Tendo em vista a necessidade de estudar uma determinada ação que permita transparecer a influência da Emater-DF sobre o território de Brazlândia, atendendo as características mencionadas logo acima, vamos nos ater ao caso específico do Projeto Sustentabilidade, que no Distrito Federal se iniciou em 2013 e encerrou as suas atividades no início deste ano, 2016. Dessa forma, será possível captar a influência da instituição sobre o território logo após a realização de uma ação estruturada para ter resultados positivos quanto a incorporação de técnicas mais sustentáveis. Neste sentido, será possível captar as impressões imediatas sobre os resultados alcançados.

O Projeto Sustentabilidade é decorrente de uma parceria estabelecida entre a EmaterDF e o Ministério do Desenvolvimento Agrário (MDA). O MDA através de um edital de chamada pública selecionou entidades de Ater em todo país para apoiar o desenvolvimento de agroecossistemas sustentáveis e a Emater-DF foi uma das entidades selecionadas para desempenhar em sua área de atuação ações pertinentes a este projeto.

O Projeto Sustentabilidade teve como propósito viabilizar a "promoção de uma rota crescente de sustentabilidade dos agroecossistemas, combinando a otimização no uso dos recursos naturais (solo, água e revestimento vegetal) e de uso de insumos que gerem qualidade, produtividade e estabilidade da produção com crescimento econômico, geração de renda e conservação ambiental" (BRASIL, 2012, p.2).

A rota de modificação dos agroecossitemas em direção a modelos produtivos mais sustentáveis é percebida pelo projeto como sendo gradual, podendo ser composta por três processos. O primeiro envolve a racionalização do uso dos recursos naturais e dos insumos químicos contaminantes e a adequação produtiva ambiental das unidades produtivas familiares; o intuito deste processo é trazer uma maior eficiência para as práticas agrícolas de forma a reduzir as contaminações e os impactos negativos ao meio ambiente, proporcionando um maior equilíbrio energético dos agroecossistemas. No segundo processo, ocorre a 
substituição dos insumos agrícolas contaminantes e aprimoramento das práticas empregadas de modo a criar condições para a resiliência dos agroecossistemas. O terceiro processo compreende o redesenho do agroecossistema para que ele seja efetivo na conservação da agrobiodiversidade, além disso, também deve abranger o apoio à comercialização em mercados diferenciados e o fortalecimento da organização social das famílias atendidas (BRASIL, 2012).

Neste sentido, busca-se incorporar o processo de melhoria contínua nas estruturas produtivas, tendo como princípio orientador a busca constante pela sustentabilidade dos agroecossistemas, a qual necessariamente envolve o equilíbrio energético e a conservação da biodiversidade, elementos presentes no arcabouço teórico da agroecologia.

Para atingir os seus objetivos, o Projeto Sustentabilidade se estruturou por meio da promoção de atividades coletivas e individuais, que deveriam levar em consideração as características e potencialidades de cada contexto territorial.

No Distrito Federal, através do Projeto Sustentabilidade, a Emater-DF atendeu 400 famílias, sendo que deste montante, 100 famílias foram atendidas pelas coordenações locais da Emater-DF em Brazlândia. Na região de Brazlândia a Emater-DF tem dois escritórios locais, o escritório de Alexandre Gusmão, que ficou responsável pelo atendimento de 20 famílias, e o escritório de Brazlândia, que ficou responsável pelo atendimento de 80 família. É importante caracterizar as diferenças entre as áreas de abrangência dos escritórios.

O escritório de Brazlândia possui uma área de abrangência de atendimento maior, ele é responsável pelo atendimento de 1120 famílias ${ }^{12}$ dispersas nas áreas rurais Cascalheira, Rodeador, Morada dos Pássaros, Barrocão, Capão da Onça, Shama e Assentamento Betinho.

O escritório de Alexandre Gusmão possui uma área de abrangência menor. O escritório é responsável pelo atendimento de 482 famílias que residem nas áreas rurais de Chapadinha, Reserva D, Incra 6, Incra7 e Incra 8, estas três últimas áreas fazem parte do antigo núcleo rural Alexandre de Gusmão.

Seguindo as diretrizes de orientação do Projeto Sustentabilidade, formuladas pelo MDA, em Brazlândia, os agricultores foram divididos em grupos de 20 famílias, definidos a partir das comunidades de produtores rurais existente na localidade. É importante mencionar que o público de famílias atendidas correspondia a produtores familiares com unidades produtivas capazes de garantir a renda familiar, haja vista que a renda anual média era de 80 mil reais.

\footnotetext{
${ }^{12} \mathrm{O}$ número de famílias atendidas pela Emater-DF possui variabilidade. Estes valores têm como referência julho de 2016.
} 
Os agricultores foram atendidos em atividades individuais e coletivas. As atividades coletivas tinham intuito de desenhar as ações segundo as necessidades da comunidade. Para tanto foram realizadas as seguintes etapas: diagnóstico rural participativo comunitário, planejamento comunitário, cursos, oficinas e avaliação final do projeto. Dentre os temas a serem abordados nas atividades coletivas, o edital de orientação para execução do projeto previa: manejo e conservação do solo; sistemas agroflorestais; produção agrícola pecuária e floresta de base agroecológica e orgânica; boas práticas no uso e manejo da água; gestão e agregação de valor aos produtos; acesso ao mercado e organização produtiva da agricultura familiar; otimização no uso dos insumos; orientações quanto à preservação e regularização ambiental; instrumentalização e acesso às políticas públicas da agricultura familiar.

As atividades individuais compreenderam: o Diagnóstico da Unidade Produtiva Familiar, a elaboração e o acompanhamento do Plano Produtivo, Econômico e Ambiental, a avaliação do projeto. $\mathrm{O}$ diagnóstico da unidade produtiva familiar consistiu no levantamento de informações variadas para traçar o perfil socioeconômico das famílias, dentre as levantadas estavam: condições de posse da terra, características produtivas, composição da renda familiar, inserção no mercado, acesso a programas públicos e infraestrutura. O Plano Produtivo, Econômico e Ambiental consistia em uma composição de ações a serem desenvolvidas sob um cronograma de execução de forma a promover uma melhoria na qualidade da produção, comercialização, infraestrutura e gestão da propriedade, considerando os fatores de produção existentes e a necessidades de investimento, sempre tendo em vista a melhoria da renda atrelada a sustentabilidade ambiental. Neste sentido, foram incentivadas atividades de promoção de transição agroecológica, elaborados projetos produtivos de acesso a linhas de crédito e intermediação, pela empresa, da inserção dos agricultores no mercado de compras institucionais ${ }^{13}$.

Em todas as etapas das atividades individuais foi garantida a participação das famílias. O intuito era fazer com que as famílias tomassem parte ativa do processo que tinha como objetivo alterar os modelos produtivos em direção a agricultura sustentável.

As atividades coletivas do Projeto Sustentabilidade em Brazlândia foram realizadas através da promoção de cursos e oficinas que abordaram as seguintes temáticas: diminuição de agrotóxicos e métodos de aplicação; rotação de culturas; adubação verde; comercialização

\footnotetext{
${ }^{13}$ As compras institucionais são decorrentes de programas governamentais que possibilitam a compra pelo poder público de produtos da agricultura familiar. Dentre estes programas estão: o Programa de Aquisição de Alimentos - PAA e o Programa Nacional de Alimentação Escolar - PNAE.
} 
dos produtos agrícolas; análise de solo; sistemas de irrigação; sistema cooperativo de produção; gestão ambiental; e produção de morango.

Segundo os extensionistas responsáveis pela condução do projeto, boa parte dos agricultores conseguiu assimilar os conhecimentos abordados pelas atividades coletivas, que consistiam em cursos de curta duração e oficinas de um dia que abordavam uma determinada temática.

Quanto aos resultados observados, os extensionistas que participaram do projeto apontam para a melhoria na estrutura produtiva dos agricultores. Tais melhorias compreenderam: instalação de sistemas de irrigação, aquisição de equipamentos para produção e elevação da produtividade devido ao uso racional dos insumos para produção. Além disso, o projeto também possibilitou que alguns agricultores se inserissem no mercado de compras institucionais, o que promove uma maior garantia do escoamento da produção.

O fato de serem elaborados planos individualizados, segundo as necessidades de cada agricultor, possibilitou que o projeto fosse adaptado aos diferentes contextos e respondesse aos anseios dos agricultores. Neste sentido, a intervenção da Emater-DF sobre a realidade produtiva dos agricultores se distanciou da imposição top down de modelos de políticas públicas de desenvolvimento rural.

Ainda pela perspectiva dos extensionistas, uma das dificuldades encontradas para o desenvolvimento do projeto foi o excesso de documentação exigido para comprovar a execução das atividades, algo que acabava por ocupar um tempo considerado das visitas técnicas às propriedades. A Emater-DF dentro deste projeto devia preencher uma série de relatórios para o MDA que era o órgão financiador e, portanto, exercia o controle da execução do Projeto.

Outro fator que dificultou o desenvolvimento do projeto foi a manutenção da frequência dos agricultores nas atividades coletivas, existindo até casos de desistências ao decorrer do projeto. Os agricultores para participar das atividades propostas, por vezes tinham que comprometer um dia de trabalho, algo que poderia ser custoso para renda familiar, já que não havia compensação monetária para participar do projeto. Em certas situações, os agricultores teriam que fazer a escolha entre deixar de receber através de suas horas trabalhadas e participar das atividades coletivas, sem, contudo, visualizar um retorno financeiro imediato para tanto.

No caso da coordenação do Projeto no escritório de Alexandre Gusmão, o problema quanto à manutenção da frequência foi contornado com o envolvimento de todos os 
componentes da família nas atividades do projeto. Neste sentido, a família poderia se revezar para garantir a integralidade da frequência nas atividades do projeto.

Dentro do projeto o acompanhamento individualizado das famílias em um período temporal de médio prazo, 2 anos, contribuiu para que os extensionistas pudessem oferecer uma assistência técnica direcionada para o alcance de objetivos previamente concebidos. Comumente as visitas técnicas às unidades produtivas não seguem uma regularidade, sendo que na maioria dos casos os atendimentos são decorrentes de respostas às demandas dos próprios agricultores. Neste contexto, a instituição não consegue exercer uma influência coerente sobre os agricultores. O Projeto Sustentabilidade se diferenciou deste contexto porque permitiu que a instituição construísse um planejamento de atuação no acompanhamento das famílias atendidas.

Um dos pressupostos atuais da política de extensão rural no Brasil é o fomento de práticas agrícolas mais sustentáveis através da promoção de princípios da agroecologia. Notamos que o Projeto Sustentabilidade, desenvolvido pela Emater-DF, conseguiu incorporar em sua execução as diretrizes da política de Ater.

Como vimos no decorrer deste capítulo a Emater-DF é influenciada diretamente pelas políticas que orientam os serviços de Assistência Técnica e Extensão Rural- Ater. O fortalecimento da dimensão ambiental nos serviços de Ater é decorrente de uma abordagem diferenciada de desenvolvimento territorial rural, onde o espaço rural é reconhecido para além do aspecto produtivo.

A dimensão ambiental dentro da política de Ater tem sido operacionalizada por meio da inserção da agroecologia como um dos princípios que devem ser valorizados nas estratégias de atendimento aos agricultores. O capítulo a seguir tem o propósito de transparecer de que forma a agroecologia contribui para os processos de desenvolvimento no território. 


\section{As contribuições da agroecologia ao desenvolvimento territorial rural}

O presente capítulo aborda duas dimensões conceituais: a agroecologia e o território/territorialidade. O intuito é trazer as contribuições destas dimensões conceituais para o entendimento sobre o desenvolvimento rural. Neste sentido, o capítulo é composto por duas seções.

A primeira seção intitulada de Agroecologia e desenvolvimento territorial rural, objetiva trazer um pouco do conteúdo dos debates que têm sido frutíferos para a construção do campo de conhecimento da agroecologia. Além disso, se propõe a apontar de que madeira esta ciência emergente pode se inserir dentro dos processos de desenvolvimento territorial rural. Para tanto, optou-se por evidenciar os significados da agroecologia a partir de três relações conjunturais de sua constituição: o surgimento da agroecologia como contraposição ao modelo de agricultura convencional; os debates sobre o desenvolvimento sustentável e as suas implicações sobre a agroecologia; e a agroecologia dentro do contexto da agricultura familiar.

Já a segunda seção, que tem como título: Território e territorialidade: o uso desses conceitos na compreensão do desenvolvimento territorial rural, busca discutir as contribuições de importantes teóricos da Geografia para o estudo da temática do desenvolvimento nos territórios rurais.

\subsection{A agroecologia como contraposição ao modelo de agricultura convencional}

O exercício de buscar as origens da agroecologia como ciência e compreender a sua consolidação dentro das práticas agrícolas a partir de meados do século $\mathrm{XX}$, requer que nos atentemos brevemente aos processos de evolução da agricultura. Tais processos foram fundamentais para que se pensasse em uma forma alternativa de cultivo de alimentos em nosso contex to atual.

A evolução da agricultura não é independente das modificações que ocorrem sobre as estruturas sociais que condicionam e relação do homem com o espaço. Ao compreendermos que a agricultura consiste na incorporação de diferentes técnicas na relação do homem com a natureza, orientadas por uma dada racionalidade a fim de oferecer os alimentos necessários à vida humana, conseguimos estabelecer uma relação entre as alterações sobre o contexto social e as alterações das técnicas que dão um teor de significado a agricultura. 
O surgimento da agricultura reduziu a quantidade de trabalho despendida para obtenção de alimentos, em comparação com as atividades de caça e coleta e, assim, a força de trabalho empregada passou a proporcionar retornos maiores de alimentos. As novas técnicas empregadas permitiram o uso dos recursos naturais segundo as necessidades dos variados grupos populacionais. Com isso, foram criadas condições que favoreciam a fixação das pessoas em dadas localidades, facilitando o nascimento de cidades e, por consequência, do comércio de mercadorias.

Apesar das estimativas quanto ao início da adoção de práticas de cultivo para a obtenção de alimentos apontarem para a região da África e do oeste asiático em alguns milhares de anos atrás, até o desenvolvimento da agricultura moderna nos séculos XVIII e XIX, não encontrávamos um sistema agrícola capaz de suprimir as necessidades de alimentos de forma global. Neste contexto, surgem teorias como a Robert Malthus que difundiu o entendimento de que a agricultura possuía limitações quanto à produção em larga escala e, sendo assim, caso permanecesse o aumento exponencial da população, a fome seria inevitável.

A agricultura por ser uma atividade essencial à vida humana não ficou à parte dos processos que a partir do século XVIII iriam transformar as relações das diversas esferas da vida humana (comercial, política e social) a fim de submeter todo o globo a uma lógica única de produção que se orientava pela acumulação do capital.

As principais limitações observadas nas práticas agrícolas empregadas até aquele momento se relacionavam com a capacidade produtiva e com o baixo potencial de padronização, necessários à incorporação de um modelo industrial na produção de alimentos.

Então, à medida que o capitalismo começava a se expandir nos países da Europa, no século XVIII, a indústria era fortalecida, as cidades cresciam e a agricultura também passava por uma série de modificações a fim de se adequar ao novo modelo de produção que se consolidava. A agricultura desenvolvida nos países europeus, nesta primeira fase de expansão do capitalismo, seguiu duas direções, como identifica Oliveira (1987).

A primeira direção se refere à transformação da agricultura em um modelo tipicamente capitalista, onde trabalho era assalariado e a exploração da terra era baseada nos arrendamentos. A segunda direção correspondeu à manutenção de formas de produção não capitalistas, tais como a produção comunitária. Neste caso a agricultura camponesa não era totalmente extinta. Em um primeiro momento, as relações não capitalistas de produção, 
próprias da agricultura camponesa, eram contraditoriamente inseridas no processo de desenvolvimento do capitalismo. (OLIVEIRA, 1987, p.31).

Oliveira (1987) também identificou algumas modificações na agricultura decorrentes da necessidade de adaptação ao capitalismo. A utilização do solo passou a ser intensificada, sendo que o tradicional pousio foi abandonado e a rotação de culturas foi adotada nos sistemas agrícolas, de forma a permitir a exploração do solo o ano inteiro. Houve também a alteração da base alimentar da população, fator que estimulou o aumento da produção de carnes. Por último, o autor também observa que tanto o desenvolvimento da divisão do trabalho quanto avanço da indústria, influenciaram a agricultura, um através do incentivo à especialização e o outro pela introdução de máquinas na produção agrícola.

Conforme as economias de capitalismo avançado se projetavam para o comércio internacional, os agricultores das colônias inglesas e dos EUA se especializavam na produção de um único produto agrícola e intencionaram o aumento da produtividade através da mecanização das lavouras. Tais modificações impulsionaram a queda nos preços dos produtos agrícolas e a diminuição da renda aferida pela produção agrícola. Assim no final do século XIX, havia uma crise na agricultura em escala mundial, onde os camponeses ficam cada vez mais pobres. Tal processo implicou na consolidação da industrialização da agricultura, isto porque:

\footnotetext{
Foi dessa maneira que começou a passagem da sujeição da renda da terra produzida pelo camponês, do capital comercial para o capital industrial e, mais que isso, com a cartelização e nascimento do capital financeiro, a sua sujeição aos monopólios (OLIVEIRA, 1987, p. 49)
}

Quando nos atemos à análise das práticas agrícolas que foram desenvolvidas no escopo deste processo, percebemos que a agricultura moderna ou convencional, que hoje se adequa ao modelo de produção capitalista, passou por uma séria de modificações de suas técnicas. Ehlers (1999) conseguiu identificar três evoluções que foram fundamentais para constituição das práticas agrícolas modernas que encontramos em nosso contexto atual.

Na Primeira Revolução agrícola as principais inovações observadas envolviam o emprego da aproximação das atividades agrícolas com a pecuária. Dentre as práticas que são empregadas durante este período estão: a rotação de culturas com plantas forrageiras leguminosas; o aumento da lotação de cabeças de gado, o que resultava em uma maior fertilidade do solo.

A criação de animais nas propriedades tinha como finalidade atender as necessidades das famílias quanto aos produtos de origem animal e proporcionar a força de tração usada 
para o trabalho da propriedade e o esterco fundamental para fertilidade do solo. Contudo, somente o esterco era insuficiente para suprir as necessidades de fertilidade, e o trabalho e o tempo, dedicados à fertilização orgânica, eram sobremodo dispendiosos (EHLERS, 1999, p. 21).

Neste sentido, a segunda Revolução Agrícola que ocorreu em meados do século XIX, foi impulsionada pela descoberta científica que apresentava uma alternativa para a fertilização do solo diferente da orgânica.

Justus von Liebig, químico alemão, notou em 1840 que a nutrição das plantas ocorria por meio de elementos químicos presentes no solo, em sua concepção, a matéria orgânica teria pouca contribuição para fertilidade do solo. Para ele a "produção agrícola seria diretamente proporcional à quantidade de substâncias químicas incorporadas ao solo" (EHLERS, 1999, p. 22). Esta teoria foi chamada de Lei do Mínimo e "impulsionou a difusão da adubação mineral à base de compostos nitrogenados, fosfatados e potássios solúveis, além do uso do calcário e de gesso nos processos produtivos" (EHLERS, 1999, p. 22).

Contudo, outros cientistas se oponham a visão de fertilidade de Liebig, e acreditavam na capacidade de fertilização do húmus. Um dos principais opositores foi Pasteur que comprovou a importância das sustâncias orgânicas para a nutrição das plantas através identificação do processo de nitrificação, onde “os nutrientes utilizados pelas plantas [...] são constantemente reciclados pela ação de microorganismos do solo que, por sua vez, dependem da matéria orgânica como fonte de nutriente" (EHLERS, 1999, p. 24).

Todavia, o posicionamento de Pasteur e de outros cientistas sobre a fertilização do solo não impossibilitou a expansão da indústria de fertilizantes artificiais que havia se implantado. Os postulados de Liebig tiveram maiores impactos na agricultura, fazendo com que os sistemas rotacionais fossem abandonados e a produção animal se afastasse da vegetal.

A Segunda Revolução Agrícola impulsionou as seguintes modificações em torno das práticas agrícolas: abandono da fertilização orgânica; valorização dos sistemas monoculturais e preferência pelas culturas com maiores perspectivas de mercado; mecanização agrícola pela adoção de motores de combustão interna; melhoramento genético; e aplicação de pesticidas para o combate de pragas. O emprego dessas novas técnicas agrícolas traria maior dependência em relação à indústria.

Já no final da década de 1960 e início dos anos 1970, o avanço das pesquisas nas áreas química, mecânica e genética e no setor industrial agrícola, resultaram na terceira revolução agrícola: a Revolução Verde. 


\begin{abstract}
A Revolução Verde fundamenta-se na melhoria do desempenho dos índices de produtividade agrícola, por meio da substituição dos moldes de produção locais ou tradicionais, por um conjunto bem mais homogêneo de práticas tecnológicas, isto é, de variedades vegetais geneticamente melhoradas, muito exigentes em fertilizantes químicos de alta solubilidade, agrotóxicos com maior poder biocida, irrigação e motomecanização (EHLERS, 1999, p.32).
\end{abstract}

A Revolução Verde atrelou ainda mais a agricultura à indústria e se espalhou por vários países através de incentivos vindos de órgãos governamentais, instituições internacionais e das próprias empresas produtoras de insumos agrícolas.

A expansão da Revolução Verde corroborou para que agricultura se industrializasse completamente, implicando no surgimento dos grandes complexos agroindustriais. Oliveira (1987) observa de mais relevante nesta fase o fato de que a renda da terra, antes decorrente do trabalho próprio do camponês, ficou submetida ao capital, havendo uma sujeição do trabalho pelos monopólios capitalistas. Como consequência, houve um aumento na concentração de terra, já que:

Esse processo geral da sujeição da terra ao capital monopolista engendra, contraditoriamente, o processo de concentração/especialização desse produtor familiar subordinado, esse camponês que conheceu, em menos de cinquenta anos, um aumento da produtividade do trabalho. Aumento esse que certamente está na base da criação dessa nova realidade: a da concentração das terras entre os camponeses (OLIVEIRA, 1987, p.58).

No cenário econômico de nossos dias, observamos o fenômeno da mundialização das economias que provoca a integração de capitais em escala mundial e faz nascer as grandes empresas mundiais. No setor agrícola, as empresas de grãos têm atuado como players no mercado das bolsas de mercadorias do mundo, sendo que possuem um controle monopolista da produção dos agrotóxicos e dos fertilizantes. (OLIVEIRA, 2012, p.7).

Logo, a atual agricultura convencional também chamada de agricultura moderna ou agricultura industrial teve os seus primórdios no final do século XIX e foi impulsionada por dois principais fatores: a necessidade de produzir alimentos em quantidade suficiente a fim de suprir a demanda da população mundial crescente e a inserção da agricultura plenamente no processo de produção capitalista. Como visto pela trajetória da agricultura descrita acima, foram desenvolvidas técnicas que possibilitaram a elevação dos níveis de produtividade e aproximaram a agricultura do modelo industrial, de modo a lhe atribuir uma padronização adequada à acumulação capitalista. Neste contexto "a produção de alimentos é tratada como um processo industrial no qual as plantas assumem o papel de fábricas em miniatura: sua produção é maximizada pelo aporte de insumos apropriados, sua eficiência produtiva é 
aumentada pela manipulação de seus genes, e o solo é o meio no qual suas raízes ficam ancoradas" (GLIESSMAN, 2001, p. 34).

O cultivo intensivo do solo, a aplicação de fertilizantes sintéticos, a monocultura, a irrigação, o controle químico de pragas e ervas adventícias e a manipulação dos genomas das plantas, são as práticas preponderantes da agricultura convencional. Embora, de fato, tais práticas terem sido fundamentais para elevação da produção de alimentos mundial, as suas consequências, tanto ambientais quanto sociais, e o não cumprimento da promessa de extinguir a fome, nos leva a questionar a sustentabilidade deste modelo produtivo.

O cultivo intensivo do solo tem aumentado o número de áreas improdutivas e as taxas de erosão, porque não há preocupação com a reposição da matéria orgânica, com a rotação dos cultivos e com o tempo de descanso da terra, fatores necessários à fertilidade (GLIESSMAN, 2001). A monocultura possibilita economias de escala, porém, por ser em si uma abordagem industrial da agricultura, requer insumos externos que causam dependência e diminuição da biodiversidade. Os fertilizantes sintéticos e agrotóxicos provocam contaminações na água e no solo que serão de difícil reversão, tendo como consequência intoxicações de seres vivos (inclusive o ser humano) e fenômenos como a eutrofização ${ }^{14}$. Por último, a manipulação genética tende a diminuir a diversidade biológica das plantas, já que incentiva a produção de plantas alteradas geneticamente com a finalidade de atender a demanda do mercado de alimentos, orientando-se pela maximização produtiva que será acompanhada pela padronização ampla das práticas de manejo.

Outro elemento importante a ser levantado, quando elencamos as consequências da agricultura convencional, é a adversidade trazida à agricultura tradicional em contextos onde as práticas agrícolas modernas tenham sido difundidas. Muitos dos agricultores familiares não conseguem se adaptar ao modelo produtivo da agricultura convencional que demanda grandes quantidades de terra e o consumo de insumos externos a unidade produtiva e, assim, abandonam suas propriedades e migram para centros urbanos. Dessa forma, os conhecimentos tradicionais associados ao cultivo de alimentos acabam sendo perdidos por falta de condições que possibilitem a sua sustentação.

Por último, é preciso apontar que tal modelo agrícola tem provocado desigualdades e tem sido pouco efetivo para redução da fome mundial. A despeito do aumento produtivo, os

\footnotetext{
${ }^{14}$ A eutrofização é um fenômeno que ocorre em corpos de água com excesso de nutrientes advindos de compostos químicos ricos em fósforo e nitrogênio. A elevação da concentração destes nutrientes na água provoca o aumento excessivo de algas, implicando na diminuição dos níveis de oxigênio. Este desequilíbrio ecossistêmico, além de diminuir a qualidade da água, provoca a morte de muitos organismos.
} 
lucros gerados permanecem concentrados, já que nem todos conseguem tomar parte no processo de produção desta agricultura (GLIESSMAN, 2001).

Como pode ser visto a agricultura convencional degrada os próprios fatores essenciais para sua sustentação, isto porque "os recursos agrícolas, como solo, água e diversidade genética, são alterados; e as condições sociais que conduzem à conservação de recursos são enfraquecidas e desmanteladas" (GLIESSMAN, 2001, p. 37). Por isso, se a agricultura convencional continuar sendo adotada em larga escala da forma como vemos hoje, futuramente não será possível o fornecimento de alimentos, já que as condições necessárias para isso terão sido destruídas.

Os insumos da agricultura convencional são dependentes de recursos naturais não renováveis, já que a fabricação de produtos agroquímicos depende da indústria petroquímica. Neste sentido, o balanço energético deste modelo agrícola é negativo, porque a principal fonte energética se fundamenta em um combustível não renovável. (Gliessman, 2001).

A agroecologia aparece neste cenário como uma alternativa para que seja possível o resgate de uma agricultura sustentável que não degrade o meio ambiente e não acentue as desigualdades. Como aponta Gliessman “a sustentabilidade é alcançada através de práticas agrícolas alternativas, orientadas pelo conhecimento em profundidade dos processos ecológicos que ocorrem nas áreas produtivas e nos contextos mais amplos dos quais elas fazem parte. A partir desta base, podemos caminhar na direção de mudanças socioeconômicas que promovem sustentabilidade de todos os setores do sistema alimentar" (GLIESSMAN, 2001, p. 52).

Por meio da agroecologia é possível valorizar os conhecimentos e as condições ambientais locais, já que "proporciona o conhecimento e a metodologia necessários para desenvolver uma agricultura que é ambientalmente consistente, altamente produtiva e economicamente viável" (GLIESSMAN, 2001, p. 54).

A agroecologia aparece como uma alternativa aos custos ambientais e sociais provocados pela adoção da agricultura convencional em larga escala. Jesus (2005) aponta a "agroecologia como o paradigma emergente, substituto da agricultura industrial ou convencional, exatamente por incorporar elementos de síntese, unificadores, integradores. Esse novo paradigma se diferencia por ter uma abordagem holística, não apenas no que concerne às questões ambientais, mas, sobretudo, às questões humanas" (Jesus, 2005, p. 40).

Uma das principais críticas sobre o modelo convencional da agricultura está relacionada com a visão mecanicista sobre o meio natural que esta imbuída na lógica deste 
modelo. Os recursos naturais são entendidos como insumos que podem ser manipulados a fim de corresponder determinados anseios, ignorando os processos complexos que estão presentes na natureza e são responsáveis por proporcionar a sustentação da geração de energia dos ecossistemas.

A agroecologia se opõe a visão mecanicista sobre o meio natural e, por isso, busca em outras áreas do conhecimento as contribuições que possibilitariam uma compreensão mais aprofundada sobre a relação do homem com a natureza para obtenção de alimentos. Neste sentido, percebe que uma agricultura que tem o intuito de oferecer gêneros alimentícios saudáveis, de forma a causar menos danos sobre ao meio natural e social, não intensificando as desigualdades, deve se ater ao desenvolvimento de técnicas que harmonizem a interferências humana sobre os ecossistemas.

A agroecologia tem sido entendida por alguns autores (CAPORAL e COSTABEBER, 2004; GLIESSMAN, 2001;) como uma ciência que recebe contribuições da agronomia, ecologia, economia, antropologia e sociologia. Sendo que os principais objetivos da agroecologia estão ligados à aplicação de princípios e conceitos que promovam o manejo de agroecossistemas sustentáveis, envolvendo a compreensão de que agricultura deve possuir também dimensões sociais e culturais, respeitando a realidade das localidades e as necessidades das populações que ali vivem.

As contribuições da sociologia a Agroecologia são decorrentes de teorias que enfatizam as transformações sociais através das lutas de movimentos sociais. Caporal e Costabeber (2004) reconhecem que a perspectiva sociológica do conflito foi a abordagem teórica sobre a qual a agroecologia lançou a suas bases iniciais. Neste sentido a agroecologia teria recebido influências dos movimentos narodnista russo e do neo populismo russo. Tais movimentos enfatizavam a importância da autonomia produtiva das comunidades e percebiam que o capitalismo pode ser enfrentado pela solidariedade do campesinato. As concepções quanto à mudança da realidade social gestadas por estes movimentos contribuíram para formação da Escola da Organização da Produção e do Programa de Agronomia Social, que se desenvolveu em 1920 e teve como principal expoente Alexander Chayanov (Sevilha Guzmán apud Caporal e Costabeber, 2004).

Os estudos antropológicos contribuíram com a agroecologia através do enfoque culturalista, permitindo o resgate da valorização dos conhecimentos tradicionais e saberes locais. Neste sentido, busca-se entender através dos estudos dos sistemas social e biológico os 
elementos que fizeram com que os sistemas agrícolas tradicionais, diferentemente da agricultura moderna, evoluíssem sem comprometer a sustentabilidade em longo prazo.

A Economia Ecológica é outro campo do saber que tem sido importante para a constituição dos conceitos e princípios incorporados pela Agroecologia. A Economia Ecológica ao fazer uso das análises das leis da termodinâmica percebe que a produtividade dos sistemas agrícolas deve ser analisada também pela perspectiva do balanço energético. Assim sendo, dependendo dos insumos utilizados na propriedade e o ciclo de energia presente, poderá haver um constante saldo energético negativo, ou seja, os sistemas agrícolas ficariam sempre dependentes de insumos externos. Por isso, são estudadas formas para o fortalecimento a independência dos sistemas agrícolas.

A Ecologia Política transmitiu à Agroecologia a perspectiva de que o estilo de desenvolvimento empregado em nossa época tem gerados impactos negativos nas dimensões ambientais e sociais. Neste sentido, as estratégias de desenvolvimento deveriam possuir uma dimensão global alinhada ao contexto local.

O ecodesenvolvimento, tendo como expoente Ignacy Sachs, também aporta alguns princípios a agroecologia como: o respeito aos ciclos de vida, o abandono da visão mecanicista do homem sobre a natureza e a importância de que desenvolvimento também se compõe pelas dimensões social, cultural e ambiental.

O desenvolvimento endógeno também é valorizado pela agroecologia de forma que o conhecimento local deve adquirir uma centralidade nos processos de desenvolvimento. Neste sentido, a construção das ações que terão impacto sobre uma dada realidade social deve ocorrer de forma participativa e respeitando matriz cultural.

A agroecologia também recebeu contribuições do neomarxismo. Neste sentido, há a valorização da análise de situações reais que tenham como foco as relações de trabalho e produção que se baseia em formas de tecnologia, sendo assim: "a Agroecologia não pode ser reduzida a um conjunto de técnicas agronômicas aplicadas à agricultura, mas precisa ser entendida como enfoque científico capaz de oferecer, também, as ferramentas para a comparação entre diferentes formas de produção e as suas respectivas lógicas de reprodução social e de apropriação da natureza" (CAPORAL e COSTABEBER, 2004, p. 105).

O entrelace da agronomia com a ecologia, também foi fundamental para a constituição da agroecologia como uma ciência. A agronomia trouxe as ferramentas necessárias para permitir o manejo dos recursos naturais a fim de produzir os gêneros alimentícios segundo as necessidades humanas e, a ecologia, por sua vez, permitiu a 
compreensão mais aprofundada sobre o sistema natural e como seus elementos se interagem a fim de permitir a sustentação da vida. A aproximação entre essas duas áreas do conhecimento para a constituição da agroecologia pode ser vista de forma mais clara nos anos 1970, onde os ecologistas passaram a reconhecer os sistemas agrícolas como áreas de estudo e os agrônomos começaram a valorizar a ecologia (GLISSMAN, 2001, p.56).

A união entre essas disciplinas trouxe o conceito de agroecossistema para centralidade das questões que procuram entender as alterações humanas provocadas sobre o meio natural para obtenção de alimentos. Os agroecossistemas podem ser definidos como "sistemas ecológicos alterados, manejados de forma a aumentar a produtividade de um grupo seleto de produtores e de consumidores" (Feiden, 2005, p. 61), e ainda " são compostos pelas interações físicas e biológicas de seus componentes", sendo que "o ambiente vai determinar a presença de cada componente, no tempo e no espaço. Esse arranjo de componentes será capaz de processar inputs (insumos) e produzir outputs (produtos)" (FEIDEN, 2005, p. 61).

Os agroecossistemas da agricultura moderna se caracterizam por um alto grau de artificializarão e dependência de recursos externos que são obtidos através do mercado, causando a dependência das propriedades. A agroecologia procura criar condições para que os agroecossistemas se aproximem das condições iniciais de um ecossistema equilibrado, sendo assim, favorece a autonomia dos agricultores e reduz os impactos ambientais. Além do aspecto ambiental, as práticas tradicionais e a cultura local são integradas no processo de produção de alimentos, rompendo com a lógica de desapropriação do campesinato que permeia o sistema convencional de produção de alimentos para o consumo.

A aproximação dos agroecossistemas ao ecossistema natural da localidade é visto por Feiden (2005) como uma maneira de garantir a sustentabilidade da agricultura. As questões sociais e o respeito à cultura e ao conhecimento local devem ser considerados na configuração dos modelos alternativos de produção. A implantação de um sistema de produção agroecológico, segundo Gomes (2005), pode ser viabilizada pelo emprego dos seguintes passos: redução da dependência de insumos comerciais; utilização de recursos renováveis presentes na localidade; reciclagem de nutrientes; introdução de espécies que criem diversidade funcional no sistema; desenho de sistemas com fácil adaptabilidade às condições ambientais locais; manutenção da diversidade; otimização e elevação dos rendimentos sem comprometer a capacidade produtiva do ecossistema natural; resgate e conservação da diversidade genética local e; resgate e conservação dos conhecimentos e culturas locais. 
Gomes (2005) observou que as mudanças no paradigma científico em nossa contemporaneidade possibilitaram o reconhecimento da agroecologia como um campo de conhecimento transdisciplinar e que percebe o meio natural através de sua complexidade.

A partir do final da década de 1980 as questões ambientais começaram a ganhar centralidade nos debates dentro da academia e das instituições promotoras de políticas públicas, fazendo com se percebesse a existência de uma concepção diferenciada no que se refere à relação entre o homem e a natureza. Tal concepção desloca a posição do homem de agente contemplador e possuidor de um domínio superior para a de agente participativo e integrado de forma orgânica ao meio natural. Vale ressaltar que esta nova percepção da relação do homem com a natureza foi fortemente influenciada por dois elementos: o surgimento de teorias científicas que apontavam para as debilidades do modelo econômico hegemônico, e as questões ambientais que permearam os debates da comunidade internacional na década de 1980, culminando no Relatório Brundtland, Nosso futuro Comum.

Desde então, a ciência tem ganhado uma flexibilidade em relação aos seus pressupostos metodológicos e o conhecimento cotidiano e tradicional são vistos como legítimos para compreender a realidade (GOMES, 2005). Neste contexto, a agroecologia surge imersa em um pluralismo epistemológico e metodológico, onde o saber tradicional pode ser associado ao conhecimento científico no desenvolvimento de práticas sustentáveis (GOMES, 2005) e, neste sentido, o conhecimento é construído "mediante a orquestração das visões de diferentes disciplinas para, mediante a análise de todo tipo de processos da atividade agrária, em seu sentido mais amplo, compreender o funcionamento dos ciclos minerais, das transformações de energia, dos processos biológicos e das relações socioeconômicas, como um todo" (GUZMÁN, 2005).

A nova concepção sobre a postura do homem frente aos recursos naturais, além de influenciar a constituição da agroecologia, também estimulou o surgimento de várias práticas agrícolas que são classificadas dentro da agricultura alternativa, ou como alguns preferem denominar, agricultura sustentável, e se caracterizam principalmente pela contraposição à agricultura convencional.

Como visto, a agricultura convencional que temos hoje foi grandemente influenciada pelos processos de modernização agrícola. Contudo, apesar da agricultura convencional ser a que predomina como determinante das práticas de cultivo no setor agrícola, ela não foi capaz de criar um contexto que impossibilitasse a proposição de práticas agrícolas menos danosas aos solos, à biodiversidade e à sociedade como um todo. 
Dessa forma, concomitantemente ao desenvolvimento da agroecologia no século XX, surgiram diversas correntes filosóficas e técnicas envolvendo a produção de alimentos orientada por uma abordagem de agricultura sustentável. No quadro a seguir é possível identificar as principais diferenças entre essas filosofias e técnicas de agricultura, consideradas próximas a um ideal de modelo sustentável.

\section{Quadro 4 - Principais formas de Agricultura Alternativa: protagonistas e princípios básicos}

\begin{tabular}{|c|c|c|}
\hline Tipologia & $\begin{array}{l}\text { Principais protagonistas } \\
\text { e seguidores }\end{array}$ & Princípios básicos e alcance \\
\hline $\begin{array}{l}\text { Agricultura } \\
\text { Orgânica }\end{array}$ & $\begin{array}{l}\text { Albert Howard; L.E. } \\
\text { Balfour; J. I. Rodale; N. } \\
\text { Lampkin }\end{array}$ & $\begin{array}{l}\text { Uso de composto, plantas de raízes profundas, atuação de } \\
\text { micorrizas na saúde dos cultivos. Difundida em vários } \\
\text { continentes. O IFOAM - Internacional Federation of Organic } \\
\text { Agriculture Movements - atua na harmonização de normas } \\
\text { técnicas, certificações de produtos e intercâmbio de informações } \\
\text { e experiências. }\end{array}$ \\
\hline $\begin{array}{l}\text { Agricultura } \\
\text { Biodinâmica }\end{array}$ & $\begin{array}{l}\text { Rudolf Steiner; Pfeiffer; } \\
\text { Shaumann Koef; } \\
\text { Petterson }\end{array}$ & $\begin{array}{l}\text { Antroposofia (ciência spiritual), preparados biodinâmicos, } \\
\text { calendário astrológico, possui marcas registradas. Presente no } \\
\text { Brasil através do Instituto Biodinâmico de Desenvolvimento } \\
\text { Rural, Estância Demétria e Instituto Verde Vida. }\end{array}$ \\
\hline $\begin{array}{l}\text { Agricultura } \\
\text { Natural }\end{array}$ & $\begin{array}{l}\text { Mokiti Okada; M. } \\
\text { Fukuoka; B. Mollison }\end{array}$ & $\begin{array}{l}\text { Composto com vegetais (inoculados com "microorganismos } \\
\text { eficientes"), valores religiosos, filosóficos e éticos. Movimento } \\
\text { organizado pela MOA - Internacional e WSAA (EUA). Shiro } \\
\text { Miyasaka dirige a atuação da MOA no Brasil. }\end{array}$ \\
\hline $\begin{array}{l}\text { Agricultura } \\
\text { Biológica }\end{array}$ & $\begin{array}{l}\text { Lamaire Boucher; Claude } \\
\text { Aubert }\end{array}$ & $\begin{array}{l}\text { A saúde dos cultivos e alimentos depende da saúde dos solos; } \\
\text { ênfase no manejo de solos e na rotação de cultivos. }\end{array}$ \\
\hline $\begin{array}{l}\text { Agricultura } \\
\text { Ecológica }\end{array}$ & $\begin{array}{l}\text { Rachael Carson, W. A. } \\
\text { Albert, S. B. Hill, E. F. } \\
\text { Shumacher; H. Vogmann }\end{array}$ & $\begin{array}{l}\text { Conceito de agroecossistema, método ecológico de análise de } \\
\text { sistemas; tecnologias suaves, fontes alternativas de energia. }\end{array}$ \\
\hline
\end{tabular}

Fonte: Hespanhol, 2009.

No contexto brasileiro essas modalidades de agricultura são juridicamente reconhecidas como agricultura orgânica, sendo que se opta por adotar este termo em um sentido genérico. A lei da agricultura orgânica, Lei $\mathrm{n}^{\circ} 10.831$ de 2003, dispõe sobre as práticas que podem ser consideradas pertencentes a sistemas de produção diferenciados. Esta lei atua, sobretudo, para regulamentar o mercado de produtos orgânicos com o intuito de garantir que os consumidores estarão usufruindo de produtos oriundos sistemas agrícolas alternativos.

A agroecologia desempenharia o papel de auxiliar os processos de transição para adoção de uma agricultura alternativa por parte dos agricultores. Isto porque este campo de conhecimento é dotado de metodologia, conceitos e princípios próprios que permitem a 
implantação e desenvolvimento de sistemas produtivos mais sustentáveis (HESPANHOL, 2009, p.128).

Todavia, não devemos reduzir o entendimento da agroecologia a apenas práticas de cultivo que podem alterar sistemas agrícolas geradores de impactos degradantes à dimensão socioambiental da sustentação da vida, já que ela não se limita:

\begin{abstract}
a abordar os aspectos meramente ecológicos ou agronômicos da produção, uma vez que sua preocupação fundamental está orientada a compreender os processos produtivos de uma maneira mais ampla. Isto é, encara os agroecossitemas como unidade fundamental de estudo, onde os ciclos minerais, as transformações energéticas, os processos biológicos, e as relações socioeconômicas são investigadas e analisadas em seu conjunto. Dito de outro modo, a pesquisa agroecológica preocupa-se não com a maximização da produção de uma atividade em particular, mas sim com a otimização do agroecossitema como um todo, o que implica em uma maior ênfase no conhecimento, na análise e na interpretação das complexas interações existentes entre as pessoas, os cultivos, os solos e os animais (COSTABEBER e COPORAL 2001, p.20).
\end{abstract}

Logo, a agroecologia tem se consolidado com uma proposta alternativa de agricultura que, embora lance mão dos conhecimentos tradicionais, não deve ser sinônimo de agricultura tradicional. A finalidade da agroecologia é promover uma compreensão mais aprofundada dos sistemas ambientais e sociais de forma que seja possível o desenvolvimento de técnicas sustentáveis, as quais minimizem a degradação dos recursos naturais.

\title{
2.2 O desenvolvimento sustentável e a agroecologia
}

É recorrente encontramos a agroecologia associado ao desenvolvimento sustentável. $\mathrm{Na}$ realidade o desenvolvimento da agroecologia como área de conhecimento tem recebido contribuições importantes das discussões teóricas que objetivam delimitar os significados do desenvolvimento sustentável. Por isso, tentaremos trazer um pouco do contexto sobre o qual o desenvolvimento sustentável tem se constituído.

O termo desenvolvimento sustentável apareceu ao final do século XX e apresenta ainda hoje várias definições, que por vezes são distintas e contraditórias. Dada às imprecisões que este termo guarda em si, sua validade teórica e prática têm sido questionadas. Todavia, consideramos que as imprecisões presentes nos debates que tentam delimitar conceitualmente o termo, apontam que o desenvolvimento sustentável estaria em um processo de construção conceitual ainda não terminado. Se o desenvolvimento sustentável é um termo que está em um processo de construção, para a sua compreensão devemos buscar os princípios e visões de mundo que estavam presente em sua gênese, assim como também, os significados que são 
atribuídos a este termo em nosso contexto atual. Esse exercício nos possibilitará entender porque o desenvolvimento sustentável não pode ser considerado como um termo fantasia, como alguns entendem.

O primeiro passo, na busca da compreensão sobre o desenvolvimento sustentável, é o regaste sobre a evolução do entendimento a respeito do desenvolvimento, já que as diferentes perspectivas teóricas sobre o desenvolvimento contribuíram para os debates em torno do desenvolvimento sustentável.

Favareto (2006), por meio da composição de uma trajetória sobre as ideias de desenvolvimento, aponta que inicialmente a concepção de desenvolvimento esteve associada à evolução da configuração histórica de uma sociedade. Assim sendo, a ideia de desenvolvimento remetia a um movimento direcional para outro estado de coisas que poderia corresponder ou não a uma ordem social superior definida ideologicamente. Contudo, as mudanças do quadro maior sobre as visões do mundo real, decorrentes da solidificação de disciplinas do conhecimento científico e das profundas alterações sobre a esfera social, provocadas pela Revolução Industrial, acarretaram um abandono da relação intrínseca entre desenvolvimento e evolução.

As ciências econômicas - que se sobrepôs as demais para explicar os fenômenos do mundo real, durante o processo da Revolução Industrial - teria sido responsável por agregar ao desenvolvimento a percepção de progresso, o reduzindo, em um segundo momento, a sua associação direta com o crescimento econômico. E assim, a economia difundiu, nas análises que buscavam justificar as diferenças entre sociedades, a percepção de que desenvolvimento era o sinônimo de crescimento econômico.

Neste sentido, compreende-se que o desenvolvimento deixa de ser reconhecido por meio de uma dinâmica natural e de longo prazo, para poder ser intencionalmente orientado, acarretando benefícios das mais diversas ordens para sociedade. Uma gama de teorias surgiu para explicar o progresso econômico, dentre elas se destacam as contribuições de Shumpeter que atribui às inovações tecnológicas a capacidade de provocar saltos sobre o desenvolvimento econômico, Douglas North que percebe nas características das instituições econômicas os motivos para o alcance de uma melhor performance da economia e Keynes que compreende a intervenção estatal como necessária para a garantia do pleno emprego econômico.

Todavia, o movimento ambientalista que ganhou uma maior visibilidade a partir da década de 1970 impulsionou, na visão de Favareto (2006), questionamentos sobre o anterior 
quadro teórico que se apoiava no crescimento econômico. E assim, surgiram novas concepções que buscavam atribuir ao desenvolvimento uma perspectiva mais abrangente, que englobava o equilíbrio entre a utilização dos recursos naturais e a produção.

O reconhecimento da necessidade de valorizar um desenvolvimento que fosse sustentável abriu espaço para discussão dos rumos do desenvolvimento que agora não deveria apenas proporcionar o aumento de renda, já que a elevação da renda não significaria necessariamente melhorias na qualidade de vida, o desenvolvimento iria para além das questões de renda, envolvendo a redução das desigualdades e o combate à pobreza.

Dentre os teóricos que repensaram os significados do desenvolvimento diante do contexto atual, Favareto (2006) atribui um grande destaque a Amartya Sen (2001). Ao se deparar com as privações impostas aos indivíduos e as desigualdades em diversas esferas, Sen percebe que o desenvolvimento só é alcançado através da constante expansão das liberdades que são ao mesmo tempo o meio e o fim do desenvolvimento.

No âmbito da teoria do autor, haveria diversos tipos de liberdades e a associação entre as liberdades promoveria o alcance de outras liberdades. O alcance de liberdades estaria dentro de um processo contínuo de desenvolvimento humano, não restrito à esfera econômica.

José Eli da Veiga (2010), também se debruçando sobre os estudos que buscam analisar o desenvolvimento a fim delimitar os seus significados, identifica três tipos básicos de repostas à questão do que realmente seria o desenvolvimento. A primeira engloba a visão de que o desenvolvimento é sinônimo de crescimento; a segunda diz respeito às declarações que afirmam que o desenvolvimento é um mito, ilusão ou crença, permeado de questões ideológicas; a última definição se encontra no caminho do meio entre as duas definições anteriores e abrange as percepções que consideram que o desenvolvimento é composto por diversas dimensões, para além da econômica, e tem como resultado a melhoria das condições da vida humana em sua complexidade, envolvendo a oferta de condições para que o indivíduo possa escolher, dentre as diversas oportunidades existentes, os rumos da sua história.

A corrente que entende o desenvolvimento como crescimento econômico considera que a renda per capita é um bom indicador para medir a qualidade de vida, já que o aumento da renda estaria diretamente associado à melhoria de outras variáveis. Os aumentos da renda viriam necessariamente acompanhados por melhorias nos indicadores de saúde e educação, por exemplo. Neste sentido, o aumento da renda seria uma espécie de catalisador de outros elementos essenciais para o alcance de melhores condições de vida. Esta visão representa um pensamento estritamente econômico, que após a solidificação de outras formas de reconhecer 
o desenvolvimento, preferiu não abandonar uma perspectiva exclusivamente quantitativa, mas justificá-la a partir do fortalecimento da relevância da renda para a melhoria dos indicadores sociais como um todo.

Embora, esta visão estritamente quantitativa ainda esteja presente em manuais de economia e seja respeitada, como identifica Veiga (2010), a sua operacionalização tem se mostrado ineficaz. O aumento da renda não proporciona uma redução das desigualdades e, em certos contextos, quando apenas beneficia um grupo limitado de pessoas, ocasiona o aprofundamento da pobreza. Tal situação se agravaria na ocorrência do incentivo à adoção impositiva de pacotes econômicos de desenvolvimento pré-formatados.

Devido às limitações da perspectiva que entende o desenvolvimento como sinônimo de crescimento econômico e a recusa em compreendê-lo apenas como uma ideia mito, Veiga (2010) identifica algumas teorias que julga representarem o caminho do meio. Um primeiro aspecto a ser destacado no que seria este caminho do meio, é o reconhecimento de que o desenvolvimento dependeria do processo social, ou seja, as transformações sociais seriam responsáveis por influenciar o conteúdo do desenvolvimento. Neste sentido, Celso Furtado declara que "o mais importante é que a ideia de desenvolvimento está no cerne da visão do mundo que prevalece em nossa época. Nela se funda o processo de intervenção cultural que permite ver o homem como um agente transformador do mundo" (apud Veiga, 2010). Assim sendo, a cultura expressa nas instituições sociais (David Landres e Douglass North apud Veiga, 2010) e os fatores ambientais (DIAMOND apud VEIGA, 2010) seriam capazes de determinar o curso dos processos de desenvolvimento.

Seguindo nas contribuições para construção de uma noção de desenvolvimento mais complexa e que aborde as diversas dimensões da vida humana e a sua interação com o meio natural, Veiga (2010), semelhantemente a Favareto (2006), reconhece importância das ideias de Amartya Sen (2001) para o contexto atual. Veiga (2010) percebe que as contribuições de Sen (2001) são preponderantes na corrente em que ele denominou de caminho do meio.

Neste sentido, o entendimento acerca de um desenvolvimento que seja suficientemente adequado para promoção de ganhos consideráveis na qualidade de vida, envolve necessariamente a superação das privações, que adquirem diferenças a depender do contexto observado. Dentre essas privações, como exemplo, podemos citar: pobreza, dificuldades de acesso aos serviços públicos, falta de participação política, diferenças de gênero, etc. 
A partir do momento que as privações são superadas, há um contexto favorável a expansão de liberdades, sendo que as liberdades seriam o meio e o fim para se alcançar o desenvolvimento. No escopo desta teoria o aspecto processual do desenvolvimento é enfatizado, já que a expansão das liberdades pode ser constante. Além disso, não é estabelecido padrões entre as sociedades com o intuito de hierarquizá-las, tendo em vista que cada sociedade é dotada de um contexto específico que determinará as condições de vida ideais para seus indivíduos.

As ideias que se apresentam constituindo o caminho do meio, apontado por Veiga (2010), traçam o panorama de que o desenvolvimento deve ser mais compreensivo possível. Neste sentido, as questões ambientais, que foram relegadas a um segundo plano nas tradicionais teorias que enfatizaram o aspecto econômico, passam a ocupar um papel central e, assim, outras ciências, como a ecologia, adquirem um protagonismo.

O pensamento liberal foi o principal responsável por constituir a concepção de que o desenvolvimento significa um crescimento econômico que tem como referência os padrões de vida e consumo das sociedades ocidentais industrializadas. Todavia quando tal concepção foi transformada em um modelo de desenvolvimento a ser implantado de forma hegemônica, os resultados negativos apareceram. A tentativa de aproximar a diversidade de sociedades que temos a um padrão único, presente nos países de industrialização avançada, teve como consequências o agravo da desigualdade, aumento dos níveis de poluição e desestabilização de ecossistemas.

Em nossa contemporaneidade, o debate sobre o desenvolvimento, segundo Caporal e Costabeber (2000), incorporou definitivamente a problemática ambiental, fato que impulsionou o processo de conceituação do desenvolvimento sustentável. Contudo, a conceituação do que seria o desenvolvimento por uma perspectiva que engloba a questão ambiental não apresenta uma linha lógica central. Ideias divergentes estão imersas no debate daqueles que advogam pela inclusão da dimensão ambiental nas iniciativas que objetivam compor um processo de modificação das sociedades em busca de condições melhores de vida. Castro (2007) aponta que desde a institucionalização do desenvolvimento sustentável e a apropriação política a nível mundial, através do Relatório Brudland, encontramos duas correntes de posições sobre o termo, uma conservadora e outra radical e libertária. Relatório Brudland é o nome popular para o relatório "Nosso Futuro Comum" elaborado pela Comissão Mundial sobre o Meio Ambiente e Desenvolvimento e publicado em 1987. 
Neste relatório encontramos princípios sobre o entendimento do que seria o desenvolvimento sustentável para aquela época, na perspectiva conservadora. Havia o reconhecimento de que os recursos ambientais tinham um limite de exploração, mas o crescimento econômico deveria ser expandido de forma que a pobreza dos países menos desenvolvidos pudesse ser superada. Sendo assim, as sociedades não sofreriam grandes alterações quanto aos padrões de consumo, o que deveria ser superado seria as tecnologias disponíveis que eram incapazes de equacionar as necessidades de crescimento econômico e os limites do meio natural.

A posição conservadora advogava pelo alinhamento do atual padrão de desenvolvimento ao pressuposto de garantia dos recursos naturais para gerações futuras sem comprometer o anseio das presentes gerações. Pareceria ser possível equalizar as demandas atuais por mais crescimento econômico com os limites do meio natural. Neste sentido, tanto o mercado quanto as instituições públicas tem se apropriado do desenvolvimento sustentável com o intuito de dar legitimidade as suas ações. Por isso, o adjetivo sustentável tem sido incorporado em uma gama de situações. Castro alerta que "à medida que 'sustentável' ganhou independência e tornou-se um rótulo a ser aplicado a qualquer coisa, o conceito de desenvolvimento sofreu um desgaste que tem contribuído para o definhamento de seu conteúdo teórico e inovador" (CASTRO, 2007, p.2).

Todavia, as concepções do que seria o desenvolvimento sustentável, difundidas pelo relatório Brundtland, não foram aceitas em sua totalidade como a solução para os problemas ambientais e sociais que se apresentavam decorrentes do padrão produtivo dos seres humanos. Naquele momento havia uma corrente de ideias que evidenciava a importância de alterações profundas no modelo econômico, essa corrente de ideias ficou conhecida como ecodesenvolvimento.

O ecodesenvolvimento teve como expoentes Maurice F. Strong e Ignacy Sachs. O ecodesenvolvimento reconhecia que o homem fazia parte do meio ambiente e rejeitava o pressuposto de que o desenvolvimento significava meramente crescimento econômico, devendo estar disponível a todas as sociedades do mundo. Além disso, o ecodesenvolviemento colocava em questão a problemática de que os padrões de consumo impostos pelos países de industrialismo avançado não só geravam problemas ambientais, mas também contribuíam para exclusão dos países subdesenvolvidos. Castro (2007) aponta que, devido a questões políticas, naquele momento, houve uma rejeição ao conceito de ecodesenvolvimento, o qual necessariamente envolvia modificações nos padrões de consumo 
e na relação entre as nações desenvolvidas com as nações subdesenvolvidas. E assim, em contraposição ao conceito de ecodesenvolvimento, que causava certo desconforto, foi popularizado o conceito desenvolvimento sustentável.

O conceito de desenvolvimento sustentável nos debates da década de 1970 se mostrava menos radical, já que o seu significado instrumental se relacionava apenas com uma equalização entre os limites ambientais e os anseios de desenvolvimento das sociedades. Neste contexto é elaborado o Relatório Brundland, onde encontramos os princípios de solidariedade sincrônica e diacrônica entre as gerações, estes princípios deveriam ser alinhados com a necessidade de se articular, coerentemente, os objetivos de ordem econômica, social e ecológica.

O ecodesenvolvimento se diferenciava da noção de desenvolvimento sustentável dos debates deste momento da história, ao considerar que há limites ao desenvolvimento que não podem ser relativizados nem mesmo pelos avanços tecnológicos. Sendo assim, em certas situações não seria possível unir de forma coerente os anseios econômicos com as questões ecológicas. Contudo, o conceito de desenvolvimento sustentável se sobrepôs ao de econdesenvolvimento, pois aquele se mostrava mais fácil de ser operacionalizado em termos políticos, incitava menos posicionamentos contrários e possuía uma elasticidade maior quanto aos pressupostos teóricos que poderiam ser agregados a sua definição.

Todavia, a despeito de inúmeras críticas ao desenvolvimento sustentável, ele permanece sendo uma alternativa para os problemas de nossa época e é apropriado por aqueles que adotam uma posição radical e libertária como uma alternativa para transformações éticas da relação do homem com a natureza. Neste sentido, percebemos que o desenvolvimento sustentável carrega em si duas correntes de concepção sobre como deveriam ocorrer as modificações em nossas sociedades a fim de garantir a manutenção das melhorias nas condições de vida. Apesar das críticas que o desenvolvimento sustentável tem sofrido ele permanece como sendo uma ideia força apropriada por diversos setores. A importância deste termo decorre dos motivos que levaram ao seu aparecimento.

O desenvolvimento sustentável deriva primordialmente do desgaste quanto à concepção de desenvolvimento associada ao crescimento econômico. O desgaste quanto esta abordagem de desenvolvimento é decorrente de uma série de fatores que podem ser identificados a partir da segunda metade no século XX nos países de capitalismo avançado. A partir daquele momento estes países se depararam com a falência das políticas de desenvolvimento, com a desordem da economia mundial e com o agravamento dos problemas 
ambientais. Além disso, o trabalho passou a ser questionado como o valor central da integração e estruturação das sociedades, já que se constituía um cenário de maior escassez de empregos formais, redução dos níveis de remuneração, aumento da exigência de qualificação e elevação no número de desempregados.

Tudo parecia apontar para a descrença de que o desenvolvimento como até então concebido poderia ocasionar progresso social e melhoria nos padrões de vida e, assim, "o desenvolvimento tornou-se uma noção pobre e desgastada: um simples rótulo de contabilização na corrida pela acumulação material de riqueza, a qual tende a diluir sua relação com o bem-estar e a felicidade humana" (CASTRO, 2007, p.8).

Era cada vez mais evidente que o padrão de desenvolvimento até então em consenso e que vigorava plenamente nas mais importantes nações do mundo, tinha provocado resultados desagradáveis para todos. A transferência do modelo de desenvolvimento industrial dos países de capitalismo aos países ditos subdesenvolvidos provou aumento da concentração de riquezas e de pobreza. Os movimentos sociais que surgiram nos anos 1960 questionavam profundamente o padrão de vida veiculado pelo modelo de desenvolvimento, esses movimentos se opuseram "ao valor central do industrialismo moderno, ou seja, à ideia de que a produção, a acumulação de riqueza, a opulência e o consumo desenfreado podem constituir fins para coletividade e para os indivíduos que as integram" (CASTRO, 2007, p.15). Começava a ser posto em questão a possibilidade de existir padrões alternativos de vida que não fossem delimitados pela rigidez e recuperassem o contato com a natureza.

Um especial destaque deve ser dado ao movimento ecológico que se constitui pela preocupação com as consequências das atividades humana sobre o seu meio de vida, Castro aponta que

\footnotetext{
a consciência ecológica originou-se não apenas de um sentimento estético, admirativo e de compaixão protetora em relação à natureza, mas também e fundamentalmente, de sua metamorfose em 'pensamento ecologizado'. Ou seja, 'a introdução do olhar ecológico na descrição e na explicação de tudo aquilo que vive' e integra o meio ambiente numa percepção em que se evidencia a ligação congênita da humanidade com o entorno ambiental (CASTRO, 2007, p. 18).
}

O movimento ecológico pressupunha uma nova racionalidade nas relações do homem com o meio natural, já que o padrão de desenvolvimento pautado pela acumulação acabaria por destruir irreversivelmente a base de vida, sendo assim o ser humano deveria abandonar sua posição de domínio déspota em relação aos recursos naturais.

Todo o debate sobre os limites do desenvolvimento frente às necessidades de conservação dos recursos naturais culminou na Conferência da Organização das Nações Unidas sobre o Ambiente Humano, realizada em Estocolmo, em 1972. Os conceitos de 
ecodesenvolvimento e o desenvolvimento sustentável, presentes nos debates daquela conferência, foram fundamentais para constituição das duas correntes, chamadas por Castro (2007) de conservadora e radical e libertária. Ambas correntes foram incorporadas ao desenvolvimento sustentável debatido em nossos dias.

Atualmente o temo desenvolvimento sustentável está extremamente popularizado, tendo ampla presença nos discursos políticos e empresarias, na academia e na mídia. Contudo, ele carrega em si uma dualidade de significados que serão conformados conforme o entendimento do locutor que fará uso do termo. Por isso, encontramos o desenvolvimento sustentável sendo aplicado em diversos contextos com diferentes interpretações.

Caporal e Costabeber (2000) ao analisarem os conteúdos destes discursos e suas consequências quando colocados em prática, elaboraram a partir de estudos já realizados por Escobar (1995 apud CAPORAL e COSTABEBER, 2000), duas classificações: uma chamada corrente ecossocial e a outra corrente econtecnocrática.

A corrente ecotecnocrática entende que tecnologias mais avançadas têm um grande potencial para trazer um equilíbrio entre os anseios de crescimento econômico e os limites da natureza, neste sentido "tenta solucionar a problemática socioambiental e os limites ao crescimento, mediante mecanismos de mercado, como podem ser o estabelecimento de preços a produtos e serviços da natureza, a cobrança de taxas ou impostos pela deterioração ambiental ou artifício de internalização das externalidades" (COPARAL e COSTABEBER, 2000, p.20). Os que pertencem a esta corrente entendem que seria preciso incentivar a implantação de pacotes tecnológicos mais eficientes e que causam menos danos ambientais. Pelo fato de ainda desconsiderarem questões culturais, sociais e territoriais neste processo de difusão de tecnologias, a adoção de suas práticas tem sido denominada de Revolução Verde Verde.

Por sua vez, a corrente ecossocial sobre influências do ecodesenvolvimento. Neste sentido, pressupõe-se a necessidade de sustentação de uma nova racionalidade baseada em dois tipos de solidariedade: a solidariedade diacrônica - ética responsável pela conservação dos recursos naturais para gerações futuras, e a solidariedade sincrônica - que diz respeito à salvaguarda ambiental para as gerações presentes. Como características da corrente ecossocial, Coporal e Costabeber consideram "possuir reivindicações de mudança profundas na sociedade e de um novo pacto de solidariedade, permitindo a construção de um novo projeto histórico e a busca de novos rumos nas estratégias de desenvolvimento" (COPORAL e COSTABEBER, 2000, p.22). 
Além das correntes de posicionamento quanto aos significados do desenvolvimento sustentável, encontramos estudos que preferem entender o desenvolvimento sustentável a partir de um arranjo de dimensões. Neste sentido, o desenvolvimento sustentável seria um termo composto por diversas dimensões que envolvem a relação do homem com o meio natural.

Castro (2007) ao tomarmos como base os estudos de Sachs e Lipiez percebe que o desenvolvimento sustentável é um conceito multidimensional com seis dimensões articuladas: a sustentabilidade econômica, a sustentabilidade ecológica, a sustentabilidade espacial, a sustentabilidade social, a sustentabilidade cultural e a sustentabilidade política.

A sustentabilidade econômica se relaciona com os parâmetros que devem ser dados ao crescimento econômico. Neste sentido, o crescimento econômico não deve ter como máxima a acumulação desenfreada, sendo necessário considerar os limites do meio ambiente. Neste ponto, a ciência través da construção de novas propostas de modelos tecnológicos poderia desempenhar um papel no sentido de oferecer os meios para possibilitar a incorporação do respeito aos processos naturais nas relações econômicas. A economia ecológica tem se apontado como uma área de conhecimento que estabelece uma ponte entre os sistemas econômico e ecológico.

A sustentabilidade ecológica se relaciona com uma nova compreensão em relação ao meio natural que deixa de ser visto como uma fonte inesgotável de recursos. Como aponta Castro a sustentabilidade ecológica lança "a base de uma nova relação entre sociedade e natureza, entre economia e ambiente, implicado condutas pró-ativas de preservação e conservação, bem como uso racional, prudente e parcimonioso dos recursos naturais" (CASTRO, 2007, p.45). Neste sentido, passa a ser demanda uma nova postura ética da humanidade em relação aos recursos naturais.

A sustentabilidade espacial se relaciona com a espacialização da sociedade e do processo econômico, interferindo essencialmente nos processos de ordenamento territorial. Neste contexto, a dicotomia rural- urbano deve ser abandonada para que o rural possa ser valorizado como um lugar onde os valores de respeito aos ciclos naturais podem ser encontrados.

A sustentabilidade social se relaciona com a construção de estratégias de desenvolvimento que permitam suprir as necessidades dos grupos sociais. Neste sentido, a garantia de moradia, educação, saúde, proteção social deve ser expandida a todos de forma proporcionar melhores condições de vida. A pobreza, então, passa a ser considerado como um 
fenômeno inaceitável dentro de nossas sociedades. Nesta questão a desigualdade seria um problema ser enfrentado.

A sustentabilidade cultural, por sua vez, leva em consideração que a cultura é um aspecto essencial da vida humana e por isso deve ser respeitada em suas diversas formas. Sendo assim, os processos de desenvolvimento não devem resultar na supressão de certas culturas, mas sim na valorização das diversas formas existentes. Assim "a sustentabilidade cultural, além de estorvar projetos de crescimento exógenos e destrutivos da cultura e identidade cultural, tem o potencial de criar condições de viabilidade para as estratégias de desenvolvimento sustentável” (CASTRO, 2007, p. 52).

Já a sustentabilidade política pressupõe que todas as atividades humanas devam ser julgadas a partir de pressupostos que levem em consideração o meio no qual são desempenhadas. Sendo assim, as contribuições da sustentabilidade política às discussões sobre o desenvolvimento sustentável se relacionam com a construção de discursos que problematizem os atuais modelos e proponham alternativas.

A abrangência dos significados que o desenvolvimento sustentável pode ter é incontestavelmente grandiosa, quando consideramos suas variadas dimensões. Por isso, tornar o desenvolvimento sustentável real implica em mudanças significativas nos modos de vida, nos levando a questionar a sua possibilidade de existência de fato. Todavia, quando observamos os ciclos biológicos presentes na natureza, conseguimos constatar que é factível a existências de processo que são sustentáveis ao longo do tempo.

Embora possa haver posicionamentos diversos quanto ao desenvolvimento sustentável, percebemos que as discussões buscam um equilíbrio entre as potencialidades e limitações presentes em diversos aspectos da vida. Neste sentido, busca-se criar saídas para problemas variados decorrentes da relação do homem com a natureza de modo que seja possível garantia a sustentação da vida de maneira harmônica.

Caporal e Costabeber (2000) quando analisam a relevância do desenvolvimento sustentável para o caso das atividades de assistência técnica e extensão rural enfatizam a importância da construção de contextos de sustentabilidade que devem ser orientados por uma lógica ecossocial. A reprodução sustentada dos modos de vida tradicionais dos agricultores de forma tal que permita melhores condições de vida e conservação do equilíbrio sistêmico do meio natural requer a adoção de iniciativas que entendam as especificidades de cada localidade, valorizando também as potencialidades do conhecimento tradicional. 
Como podemos ver dentro do debate da adjetivação sustentável ao desenvolvimento, há várias posições que variam desde concepções mais quantitativistas que entendem o meio natural como uma fonte de recursos, ou melhor dizendo, parte dos inputs necessários ao processo de sustentação econômica, até as concepções que têm uma ideia mais compreensiva do desenvolvimento sustentável, advogando em favor de transformações profundas nos modos de vida.

Devido a este cenário, há autores que entendem o desenvolvimento sustentável como uma ideia vazia susceptível às intempéries das vontades políticas. Sendo assim, o conteúdo do conceito iria variar conforme os interesses ideológicos de determinados grupos.

Todavia, não devemos nos ater a busca de um significado homogêneo e consensual do desenvolvimento sustentável, isso dificilmente seria possível. A importância está no aspecto processual de construção deste termo que evidencia a forma que vemos a relação entre o homem e natureza e como gostaríamos que ela evoluísse ao longo do tempo. Como destaca Veiga:

a sustentabilidade não é, e nunca será, uma noção de natureza precisa, discreta, analítica ou aritmética, como qualquer positivista gostaria que fosse. Tanto quanto a ideia de democracia - entre muitas outras ideias tão fundamentais para evolução da humanidade -, ela sempre será contraditória, pois nunca poderá ser encontrada no seu estado puro (VEIGA, 2010, p. 165).

E ainda continua,

Acontece que estão justamente nas fraquezas, imprecisões e ambivalências da noção de sustentabilidade as razões de sua força e aceitação quase total (...). Sendo assim, sua força está em delimitar um campo bastante amplo em que se dá a luta política sobre o sentido do que deveria ser o meio ambiente no mundo contemporâneo. Além disso, esse conflito está ancorado, em última instância, nas diferentes visões sobre a institucionalização da problemática ambiental (VEIGA, 2010, p. 164).

Apesar das diferentes ideias que por vezes são contraditórias encontradas no debate acerca do desenvolvimento sustentável, Coporal e Costabeber advogam em favor da relevância deste termo em nossos dias, pelo fato dele poder provocar transformações contínuas na relação do homem com a natureza, ainda entendem que "a sustentabilidade não é algo estático ou fechado em si mesmo, mas faz parte de um processo de busca permanente de estratégias de desenvolvimento que qualificam a ação e a interação humana nos ecossistemas" (COPORAL e COSTABEBER, p. 23, 2000). 
Para que a sustentabilidade realmente gere os resultados positivos esperados, o processo de construção de contextos de sustentabilidade, através da assistência técnica e extensão rural, deve possuir algumas condições: ruptura das formas de dependência; utilização dos recursos do próprio agroecossistema; não alteração substantiva do meio ambiente; utilização dos impactos benéficos decorrentes dos ciclos do ecossistema; estabelecimento de mecanismos de regeneração; valorização dos conhecimentos locais; estabelecimento de circuitos curtos de consumo em benefício da população local; e potencialização da diversidade biológica e sociocultura (SEVILLA GUSMÁN apud COPORAL E COSTABEBER, 2000, p. 24).

A assistência técnica e extensão rural pode auxiliar na construção de contextos de sustentabilidade quando adota uma postura diferenciada em relação ao atendimento promovido aos agricultores. A assistência técnica que adota os princípios e conceitos da agroecologia possui características diferenciadas como: a) fomentar o desenvolvimento local, b) entender os agroecossistemas como sistemas complexos que devem minimizar os impactos ambientais no cultivo de alimentos, c) reconhecer que o processo de construção de conhecimentos ocorre de forma dialógica.

\section{Quadro 5 - Comparação entre tipos de extensão rural}

\begin{tabular}{|c|c|c|}
\hline Indicadores & Extensão Rural Convencional & Extensão rural agroecológica \\
\hline $\begin{array}{l}\text { Bases teóricas e } \\
\text { ideológicas }\end{array}$ & $\begin{array}{l}\text { Teoria da Difusão da Inovações. } \\
\text { Conhecimento científico em } \\
\text { primeiro lugar }\end{array}$ & $\begin{array}{l}\text { Desenvolvimento local. Agricultor em } \\
\text { primeiro lugar. Resistência dos camponeses }\end{array}$ \\
\hline $\begin{array}{l}\text { Principal } \\
\text { objetivo }\end{array}$ & $\begin{array}{l}\text { Econômico. Incremento de renda } \\
\text { e bem estar mediante a } \\
\text { transferência de tecnologia. } \\
\begin{array}{l}\text { Aumento da produção e e } \\
\text { produtividade }\end{array}\end{array}$ & $\begin{array}{l}\text { Ecossocial. Busca de estilos de } \\
\text { desenvolvimento } \\
\text { equilibrado e ambientalmente sustentável. } \\
\text { Melhorar as condições de vida com proteção } \\
\text { ao meio ambiente. }\end{array}$ \\
\hline $\begin{array}{l}\text { Compreensão } \\
\text { sobre o meio } \\
\text { ambiente }\end{array}$ & $\begin{array}{l}\text { Base de recursos a ser explorada } \\
\text { para alcançar objetivos de } \\
\text { produção e produtividade. } \\
\text { Aplicação de } \begin{array}{l}\text { técnicas de } \\
\text { conservação }\end{array} \\
\end{array}$ & $\begin{array}{l}\text { Base de recursos que deve ser utilizada } \\
\text { adequadamente de forma a alcançar } \\
\text { estabilidade nos sistemas agrícolas. Evitar ou } \\
\text { diminuir impactos ao ambiente e aos estilos de } \\
\text { vida. }\end{array}$ \\
\hline $\begin{array}{l}\text { Compreensão da } \\
\text { agricultura }\end{array}$ & $\begin{array}{l}\text { Aplicação de técnicas e práticas } \\
\text { agrícolas. Simplificação e e } \\
\text { especialização. }\end{array}$ & $\begin{array}{l}\text { Processo produtivo complexo e diversificado, } \\
\text { em que ocorre a co-evolução das culturas e dos } \\
\text { agroecossistemas. }\end{array}$ \\
\hline $\begin{array}{l}\text { Agricultura } \\
\text { sustentável }\end{array}$ & $\begin{array}{l}\text { Intensificação verde. Aplicação } \\
\text { de tecnologias mais brandas e } \\
\text { práticas conservacionistas em } \\
\text { sistemas convencionais. }\end{array}$ & $\begin{array}{l}\text { Orientação agroecológica. Tecnologias e } \\
\text { práticas adaptadas a agroecossistemas } \\
\text { complexos e diferentes culturas. }\end{array}$ \\
\hline Metodologia & $\begin{array}{l}\text { Para transferência de informação } \\
\text { e assessoramento técnico. } \\
\text { Participação funcional dos } \\
\text { beneficiários. }\end{array}$ & $\begin{array}{l}\text { Para recuperação e síntese do conhecimento } \\
\text { local, construção de novos conhecimentos. } \\
\text { Investigação-ação participativa. }\end{array}$ \\
\hline Comunicação & $\begin{array}{l}\text { De cima para baixo. De uma fonte } \\
\text { a um receptor. }\end{array}$ & $\begin{array}{l}\text { Diálogo horizontal entre iguais. } \\
\text { Estabelecimento de plataformas de negociação }\end{array}$ \\
\hline
\end{tabular}




\begin{tabular}{|l|l|l|}
\hline Educação & $\begin{array}{l}\text { Persuasiva. Educar para a adoção } \\
\text { de novas técnicas. Induzir ao } \\
\text { cambio social. }\end{array}$ & $\begin{array}{l}\text { Democrática e participativa. Incrementar o } \\
\text { poder dos agricultores para que decidam. }\end{array}$ \\
\hline Papel do agente & $\begin{array}{l}\text { Professor. Repassar tecnologias e } \\
\text { ensinar práticas. Assessor técnico. }\end{array}$ & $\begin{array}{l}\text { Facilitador. Apoio à busca e identificação de } \\
\text { melhores opções e soluções técnicas e não } \\
\text { técnicas. }\end{array}$ \\
\hline
\end{tabular}

Fonte: Caporal, 2004, p.76

Por isso, entendemos que a relevância do desenvolvimento sustentável está no processo de trazer para o plano concreto as iniciativas que são orientadas pela busca de uma relação homem e natureza mais harmônica.

Logo, as contribuições da agroecologia ao desenvolvimento sustentável, e vice e versa, consistem na consolidação de um novo paradigma sobre a relação do homem com a natureza, no qual a natureza deixa de ser vista como uma provedora de insumos e, o homem deixa de ocupar a posição de observador dos processos naturais. Neste sentido, há de se pensar nos diferentes contextos de sustentabilidade que estão sendo construídos e analisar as suas contribuições para o alcance de condições melhores de vida para os seres humanos e o meio natural.

\subsection{A agricultura familiar e a agroecologia}

Antes de discorremos sobre a relação entre a agricultura familiar e a agroecologia é importante esclarecer sobre o conceito de agricultura familiar que tem sido adotado por esta pesquisa. Campesinato, agricultura camponesa familiar e agricultura familiar têm sido termos usados para representar um determinado grupo social que possui uma centralidade no núcleo familiar e tem particulares nos padrões de relação com a terra e em seus modos de vida. Todavia, há preferências na utilização de um termo em detrimento de outro que se justificam pelo reconhecimento das transformações deste grupo social em nossa modernidade.

Para alguns, a agricultura familiar está associada à necessidade de criar um perfil específico de público que se beneficia das políticas públicas de uma abordagem diferenciada de desenvolvimento rural, dentre as quais estão o Programa Nacional de Fortalecimento da Agricultura Familiar- Pronaf acompanhado da Declaração de Aptidão de Programa Nacional de Fortalecimento da Agricultura Familiar - DAP, um documento que permiti o acesso a uma série de outras políticas. Neste sentido, o Estado desempenharia o papel de construir os limites da identidade da agricultura familiar. No entanto, há argumentos contundentes capazes de se contrapor a esta visão, os quais se encontram no fato dos movimentos sociais do campo tomam para si a categoria de agricultura familiar (WANDERLEY, 2004). Por isso, não é apenas um termo criado para viabilizar a operacionalização de políticas. Sendo assim, é 
necessário que nos adentremos nos motivos que levaram o florescimento da agricultura familiar dentro da corrente teórica que aborda a constituição deste grupo social. Para tanto, primeiramente, pontuaremos sobre os significados do campesinato.

O campesinato tem sido tratado por duas dimensões. Uma enfatiza o aspecto tradicional, por entendê-lo a partir da construção histórica de uma cultura e de uma civilização. E outra o entende como uma classe social que possui uma forma particular de organização da produção que garante a sua reprodução. Neste escopo, a agricultura camponesa passa a ser a expressão do tipo de agricultura desempenhada pelo campesinato (WANDERLEY, 2004).

Todavia sabemos que o campesinato não esteve isolado dos processos de modernização, os quais fizerem com que os núcleos familiares agregassem em seus meios de reprodução social outras técnicas. A transformação decorrente da adoção de novas técnicas fez emergir a categoria de agricultura familiar que se relaciona com a modernidade. Todavia, Wanderley (2004) aponta que não existe um processo evolutivo entre uma categoria e outra, ou seja, o campesinato estaria em um estado pretérito ao do agricultor familiar, porque "existe pontos de ruptura e elementos de continuidade" (WANDERLEY, 2004, p.47). Sendo assim, os agricultores se adaptaram a um novo contexto econômico e social, porém ainda permanecem com as características que lhes conferem singularidade, as quais se relacionam principalmente com “a lógica familiar, cuja origem está na tradição camponesa (...) permanece inspirando e orientando - em proporções e sob formas distintas, naturalmente - as novas decisões que o agricultor deve tomar nos novos contextos a que está submetido" (WANDERLEY, 2004, p.48). É por isso que a agricultura familiar aparece em nossa contemporaneidade ligada a fenômenos com a pluriatividade e a multifuncionalidade.

Nesta pesquisa temos optado por adotar o termo de agricultura familiar com o intuito de ressaltar seu aspecto de transformação e consolidação como um ator social no rural brasileiro, que se manteve mesmo após processos de modernização agressivos que causaram impactos negativos a sua sustentação, os quais já foram discutidos nas seções anteriores.

Sendo assim, não abordaremos diferenças entre os agricultores familiares e o campesinato, na realidade entendemos que os termos são utilizados para caracterizar um mesmo grupo que se define pela centralidade na família, pelos modos de vida e práticas que conferem um teor diferenciado na relação com a terra. Por isso, usaremos caracterizações convergentes em relação ao campesinato e agricultura familiar presentes na literatura que 
aborda a temática. Sendo assim, tais termos poderão aparecer como sinônimos no decorrer desta seção.

Percebemos que há uma forte relação entre a agricultura familiar e agroecologia. A agroecologia tem buscado nas práticas tradicionais do cultivo com a terra os princípios sobre os quais podem ser desenvolvidas outras técnicas e tecnologias que prezem por uma perspectiva complexa do meio natural que não o considere apenas como insumos de processos de produção. Por outro lado, os movimentos sociais representativos da agricultura familiar buscam na agroecologia os motivos sobre os quais pode ser fundamentada uma agricultura sustentável. Sendo assim, identificamos um princípio dialético entre uma ciência que se estrutura e um grupo social que se mantém sólido mesmo após sofrer uma série de processos de modernização carregados de intencionalidades para dissolvê-lo.

Os movimentos sociais que representam os interesses da agricultura camponesa familiar têm incorporado a questão da agroecologia em suas reivindicações de forma a constituírem um projeto para o campo que abranja as dimensões socioambientais do desenvolvimento. A luta não se concentra apenas no direito à terra e acesso às políticas de fomento à produção rural, também há a preocupação sobre as implicações da produção sobre o território e o meio natural (ALMEIDA, 2009).

Neste sentido, a agricultura familiar e a agroecologia têm cada vez mais estreitado os seus laços de interdependência. Contudo, devemos destacar que nem toda a produção da agricultura familiar pode ser considerada agroecológica, como bem ressalta Saquet (2014):

\footnotetext{
Nem todo agricultura camponesa é agroecológica, mas as práticas agroecológicas são camponesas, ou seja, não são empresariais, envolvendo conhecimentos, técnicas, tecnologias e princípios como a cooperação e a valorização do patrimônio ecológico e familiar bem como a organização política e luta num movimento de resistência à chamada Revolução Verde e a expansão do capital (SAQUET, 2014, p. 132).
}

A constituição dos territórios depende em grande medida dos agentes que o compõem, assim como também, dos aspectos subjetivos que irão orientar as atitudes, decisões e relações construídas por tais agentes. Sendo assim, podemos perceber que agricultura familiar pode possuir uma dada territorialidade que receberá influências da agroecologia, como aponta Saquet (2014) a agricultura camponesa vem "territorializando-se historicamente de distintas maneiras, como por meio das práticas (agro)ecológicas, adaptando-se às condições sociais e naturais produzindo alimentos sem insumos químicos, valorizando os conhecimentos repassados de geração em geração e a cooperação" (SAQUET, 2014, 129). 
Como exposto anteriormente, os valores e ideias de mundo compartilhadas por um grupo social interferirá grandemente sobre a forma que se dará relação do homem com a natureza. Dessa forma, identificamos na agricultura familiar e na agroecologia elementos que conjuntamente podem orientar a constituição de práticas agrícolas que respeitem os recursos naturais que dispomos.

Após estudar uma série de autores clássicos e contemporâneos que abordam a agricultura camponesa, Saquet (2014) sintetiza as principais características deste grupo social que possui uma singular relação com a terra. Tais características são destacadas abaixo:

- Possuir um vínculo com a terra e um sentido de pertencimento a um grupo que compartilha uma mesma cultura e práticas cotidianas centradas no sustenta da família.

- Apresentar como objetivo maior a sustentação e reprodução da família tanto na dimensão social quanto biológica.

- Desenvolver uma estreita relação entre a produção e consumo familiar orientado por uma cooperação mútua ente os membros da família.

- Ser submetidos há uma lógica de circulação de mercadorias própria, com uma autonomia relativa frente ao mercado capitalista.

- No estabelecimento agrícola há o predomínio da mão de obra familiar, que em momentos específicos conta com o auxílio dos mutirões e outras formas cooperativas de trabalho.

- A organização dos camponeses é orientada para socialização e reprodução da força de trabalho.

- Possuir os meios de produção, terra, insumos e maquinário.

- Ter a jornada de trabalho regulada pelos períodos de plantio e colheita.

Os valores de cooperação e solidariedade permeiam as relações constituídas entre os agricultores familiares que nem sempre estão orientados somente pela maximização dos lucros. Neste sentido, os recursos naturais tende a ser vistos como necessário a manutenção da vida e não como meros insumos de um processo produtivo que em última instância visa apenas a acumulação. Por isso, os ciclos naturais são respeitados e incorporados em práticas culturais expressas de diversas formas, uma delas as festas típicas. 
A solidariedade existente entre os camponeses não é significativa apenas para dar sentido às relações e vínculos constituídos, através dos laços de solidariedade também é possível identificar os limites territoriais estabelecidos. Em uma das obras clássicas da ruralidade paulista, de autoria de Antônio Candido (1964), Os Parceiros do Rio Bonito, o autor bem expõe como as relações de cooperação e solidariedade são fundamentais para o entendimento dos sistemas territorial do espaço rural. O autor percebe que os bairros rurais, entendidos a partir de uma perspectiva do território, seriam um espaço geográfico de certa forma autônomo, onde as pessoas que nele habitam adquirem uma consciência de pertencimento e unidade.

Os membros que compõe um bairro, conforme as necessidades dadas pelas atividades agrícolas de colheita, preparo da terra, beneficiamento primários de alimentos, etc., se organizam para trabalharem coletivamente nas propriedades através de eventos denominados mutirões. Neste contexto cada família que recebe o trabalho dos seus vizinhos fica moralmente obrigada a retribuir quando for chamada para compor a força de trabalho de um mutirão que será realizado em outra propriedade pertencente ao mesmo bairro.

Dessa forma, é possível compreender que os limites dos bairros dependem da colaboração dos moradores em trabalhos de ajuda mútua. Vale destacar que não há nenhuma espécie de contribuição financeira para quem oferece sua ajuda aos trabalhos, há apenas a garantia que o esforço despendido será retribuído. Antônio Candido (1964) ainda aponta que os limites dos bairros também podem ser compreendidos através das atividades religiosas compartilhadas pelos seus membros. As atividades religiosas acabariam por ser um elemento de integração social.

Os laços sociais constituídos entre os agricultores familiares, a relação estabelecida com o meio natural para a obtenção de alimentos, os movimentos sociais representativos da agricultura familiar que incorporam a dimensão ambiental em suas reivindicações, são elementos que contribuem para que a agroecologia seja desenvolvida dentro das unidades produtivas familiares. E neste sentido, a agroecologia não é incorporada apenas como um conjunto de práticas ou um modelo produtivo agrícola, mas sim como um meio para que os agroecossistemas sejam inseridos em processos de construção de contextos sustentáveis de base territorial.

É importante salientar que a agroecologia não pretende submeter os diferentes territórios a um determinado padrão, já que preza pelo respeito à pluralidade existente nos diferentes ecossistemas e agrupamentos sociais. É um desafio às políticas públicas de 
desenvolvimento rural adquirir uma perspectiva que não homogeneíze os contextos territoriais, porque os gestores públicos tendem a padronizar os processos, abrindo pouco espaço para a adaptação segundo as peculiaridades de cada contexto. Neste sentido, como aponta Almeida (2009), o campo agroecológico tem o esforço de fazer "confluir a diversidade

de suas inserções socioambientais para a produção de sínteses que traduzam os conhecimentos gerados a partir das experiências locais e que projetem propostas mais amplas de políticas públicas que, simultaneamente, demarquem um claro divisor de águas com os pressupostos reducionistas e excludentes do agronegócio e deem suporte à produção familiar de base agroecológica" (ALMEIDA, 2009, p. 80).

\subsection{Território e territorialidade: o uso desses conceitos na compreensão do desenvolvimento territorial rural}

Como discutido no capítulo um, o reconhecimento da existência de um novo rural brasileiro é decorrente das análises que verificaram os impactos dos modelos de desenvolvimento da segunda metade do século XX sobre o espaço rural brasileiro (EHLERS 1999, GRAZIANO DA SILVA, 1981). Naquele momento os territórios rurais brasileiros foram considerados apenas como um receptáculo de um determinado modelo de produção agrícola. Todavia, contrariamente a visão que se mostrava hegemônica e percebendo as transformações que o rural tem sofrido em nossa contemporaneidade, um conjunto de autores converge para o entendimento de que os territórios rurais são multifuncionais, capazes de abrigar não somente um único modelo de desenvolvimento e que a pobreza do meio rural deve de ser combatida por meio de ações estruturantes que fortaleçam as potencialidades de cada localidade e a agricultura familiar (ABRAMOVAY, 2009; FAVARETO, 2006; GRAZIANO DA SILVA e CAMPANHOLA, 2004; SABOURIN, 2008; SCHNEIDER, 2004; VEIGA, 2001).

Neste cenário, a abordagem territorial nas políticas públicas para o rural brasileiro, tem sido enfatizada devido à descentralização das políticas públicas e à nova postura de intervenção estatal que passa a se concentrar na promoção de condições para que os agentes do território possam alocar de forma eficiente os recursos (FAVARETO, 2006).

Sendo assim, noções como território e territorialidade têm sido trabalhadas para auxiliar na compreensão sobre os processos induzidos pelo poder público sobre o rural. Com o intuito de obter uma compreensão mais aprofundada sobre o território/ territorialidade e como estas noções podem auxiliar na compreensão das políticas públicas direcionadas ao 
desenvolvimento rural, a presente seção deste capítulo recorrerá às contribuições de teóricos do campo de conhecimento da geografia.

O campo do conhecimento da geografia tem muito a colaborar com os estudos semelhantes aos propósitos desta pesquisa, estudos como este que são direcionados pelo entendimento sobre o conteúdo do desenvolvimento conduzido pelo poder público em uma perspectiva socioespacial.

Com o intuito de obter uma análise expandida sobre o objeto foram selecionadas as contribuições de três teóricos da Geografia, Claude Raffestin, Milton Santos e Jöel Bonnemaison. Cada um destes teóricos possuem singularidades em suas visões sobre o espaço geográfico.

Claude Raffestin possui uma argumentação lógica matemática, por isso é comum em suas análises o uso do suporte de funções, gráficos de vetores em planos cartesianos e sistemas. Neste sentido, o autor tende a primeiramente identificar os elementos que compõem uma dada realidade para depois os correlacionar.

Neste sentido, Raffestin (1993) percebe que o território é decorrente do processo de interação entre a sociedade e o espaço, semelhantemente a uma relação de função, o território surgeria do espaço. O território seria uma projeção das relações do vivido individual e coletivo desenvolvidas dentro do espaço.

Os atores adquirem um protagonismo nas análises de Raffestin pelo fato de serem eles responsáveis por determinar o curso das relações socioespaciais que ao longo do tempo, inevitavelmente, influenciarão a constituição territorial.

Segundo o autor, os objetivos dos atores, suas intenções e projetos são necessariamente permeados por relações de poder, pois nem todos possuem convergências quanto as suas projeções sobre o território. Sendo assim, a análise das pretensões dos atores sobre o território é de grande relevância para a constituição territorial que dependente "de uma ação conduzida por um ator sintagmático (ator que realiza um programa) em qualquer nível. Ao se apropriar de um espaço, concreta ou abstratamente (por exemplo pela representação), o ator 'territorializa' o espaço. ” (RAFFESTIN, 1993, p.143).

Os atores exercerão influência sobre o território na medida em que possuem poder. Este poder se origina a partir do acesso a energia e informação, convertidos em trabalho. Contudo, devemos ressaltar que não há uma relação direta entre o poder de um ator e a influência que este exercerá sobre o território com o objetivo de ter suas projeções concretizadas. As realizações sobre um dado território são o resultado da interação entre os 
atores e os fatores relacionados com o meio. Neste sentido, o poder deriva, substancialmente, das relações estabelecidas em um dado sistema territorial.

A sustentação da prática espacial, ou seja, as condições necessárias à produção do território são dadas pelo sistema territorial. O sistema territorial é composto por tessitura, nó e rede, isto porque "toda prática espacial, mesmo embrionária, induzida por um sistema de ações ou de comportamentos se traduz por uma produção territorial que faz intervir tessitura, nó e rede" (RAFFESTIN, 1993, p.150).

A tessitura diz respeito à forma como a superfície espacial está dividida entre os atores, estabelecendo assim os limites das ações. Os nós são as posições dos indivíduos ou grupos na malha territorial e representam "todo ego, individual ou coletivo" (RAFFESTIN, 1993, p.157) das respectivas representações sobre o território. As redes, por sua vez, são originadas das múltiplas espécies de relações entre os atores, as quais consistem nas necessidades dos atores de exercer influência, controle, manter funções, possibilitar aproximação e distanciamento, assim "toda a rede é uma imagem de poder ou, mais exatamente, do poder do ou dos atores dominados" (RAFFESTIN, 1993, p.157).

No que se refere à territorialidade, o autor entende que ela transparece os princípios sobre os quais se darão as relações presentes em cada sistema territorial, assim sendo "cada sistema territorial segrega sua própria territorialidade, que os indivíduos e a sociedade vivem" (RAFFESTIN, 1993, p.161). O autor ainda critica as concepções de territorialidade que restringem o seu entendimento apenas à apropriação do território pelos indivíduos, já que a territorialidade "pode ser definida como um conjunto de relações que se originam num sistema tridimensional sociedade-espaço-tempo em vias de atingir a maior autonomia possível, compatível com os recursos do sistema" (RAFFESTIN, 1993, p.160). Sendo assim, a territorialidade "refletiria a multidimensionalidade do 'vivido' territorial pelos membros de uma coletividade" (RAFFESTIN, 1993, p. 158).

Neste sentido, a partir da territorialidade compreenderíamos a maneira pela qual as sociedades em um dado momento do tempo e local fazem uso do território a fim de suprir as suas necessidades através da construção de um sistema relacional.

Milton Santos, por sua fez, considera a existência de uma profunda relação entre espaço e sociedade, através da qual se percebe que a materialização das relações sociais ocorre no espaço e o espaço exerce uma relação dialética com a sociedade. Por isso, o espaço não é um agente passivo no processo social. 
O autor estabelece 4 categorias analíticas que permitem compreender a totalidade do espaço, sendo elas: forma, função, estrutura e processo, as quais, quando consideradas em seu conjunto relacional, permitem compreender os fenômenos espaciais em sua totalidade.

A forma diz respeito àquilo que se apresenta visível nos espaços e retrata um arranjo de objetos sob um determinado padrão. A função dá sentido ao estabelecimento da forma, já que é através da função que podemos perceber a que se propôs a constituição do espaço. A estrutura, por sua vez, se refere à "inter-relação de todas as partes de um todo" (SANTOS, 1985, p.50), sendo assim, estará intimamente relacionada com o modo de organização social. E por fim, o processo implicará no movimento em direção ao tempo dos espaços, o qual está diretamente associado com as mudanças e alterações nos sistemas espaciais.

As categorias analíticas devem ser tomadas em seu conjunto relacional para uma adequada compreensão do espaço geográfico, ou seja, elas não devem ser interpretadas de forma separada, se isto acontecer, não haverá um entendimento da totalidade sócio-espacial. Assim percebe o autor que "a totalidade do real, implicando em um movimento (processo) comum de estrutura, função e forma, é uma totalidade concreta e dialética" (SANTOS, 1985, p.58).

O espaço dialeticamente se relacionada com a sociedade. O espaço exerce um papel sobre a construção das relações sociais, assim como também é afetado pela sociedade, neste sentido, relações de produção são ao mesmo tempo sociais e espaciais. Assim sendo, "a sociedade só pode ser definida através do espaço, já que o espaço é o resultado da produção, uma decorrência de sua história - mais precisamente, da história dos processos produtivos impostos ao espaço pela sociedade" (SANTOS, 1985, p.49).

Quando destacamos a categoria analítica do processo, entendemos, que pela perspectiva de Milton Santos, ele está relacionado com as mudanças contínuas observadas ao longo do tempo, onde cada elemento espacial "passa por uma mudança de valor relativo a cada mutação" (SANTOS, 1985). O processo age e reage sobre o conteúdo do espaço, por isso esta categoria analítica deve ser entendida em uma perspectiva dialética na totalidade que compõe.

Outro conceito usado pelo autor em busca de um entendimento mais aprofundado do espaço é o das formas-conteúdo. Não haveria formas sem conteúdo, já que essas dependem dos significados constituídos pela ação humana.

As formas-conteúdo seriam expressas em bases territoriais. E, neste contexto, o território carregaria a propriedade de ser a base da totalidade da formação sócio-espacial de 
cada sociedade. Neste sentido, o território só adquire significado de existência a partir da análise dos processos necessários a sua constituição.

Dessa forma, Milton Santos procura transmitir o entendimento da noção de território através do reconhecimento de sua complexidade e relevância dentro da materialidade espacial da existência humana. Por isso, o autor alerta para a necessidade de não tomar como elemento de análise o território em si, mas sim o seu uso. O uso do território remete a complexidade da vida humana que se transcorre de forma dinâmica e em diversas dimensões, econômica, social e cultural.

É o uso do território, e não o território em si mesmo, que faz dele objeto da análise social. Trata-se de uma forma impura, um híbrido, uma noção que, por isso mesmo, carece de constante revisão histórica. O que ele tem de permanente é ser o quadro de vida. Seu entendimento é, pois, fundamental para afastar o risco de alienação, o risco da perda do sentido da existência individual e coletiva, o risco a renúncia ao futuro (SANTOS, 1998, p.17).

O território abrigaria os elementos necessários à vida humana, por isso são formas, "mas o território usado são objetos e ações, sinônimo de espaço humano, espaço habitado" (SANTOS, 1998, p.16). Neste sentido, os diversos processos que moldam as relações sociais teriam influência sobre o território que em nosso contexto de modernidade tem sido cada vez mais interconectado com outros territórios devido também à evolução tecnológica que confere a relação espaço tempo uma nova conotação.

A análise do território a partir do seu uso transparece também as funções que são esperadas para as formas - categoria analítica para compreender o espaço geográfico.

Entender o espaço geográfico a partir do território usado, evidência a participação dos diversos atores nos processos de constituição deste. Sendo possível atribuir aos atores a capacidade de alterarem a realidade material de que fazem parte.

Ao entendermos que o objeto de análise nas questões territoriais deve ser o território usado, devemos fazer o exercício de identificar os elementos que poderiam influenciar dialeticamente o curso dos processos espaciais que se manifestam no uso do território. A intencionalidade pode ser destacada como um elemento presente nas ações e nos objetos do espaço geográfico que nos permitir ver além daquilo que se mostra aparente.

Milton Santos (2014) destaca que a noção de intencionalidade também é eficaz "na contemplação do processo de produção e de produção de coisas, considerados como resultado da relação entre o homem e o mundo, entre o homem e o seu entorno" (SANTOS, 2014, p. 90). Neste sentido, as ações que ocorrem dentro de um terminado contexto territorial 
carregarão determinadas intencionalidades que são aportadas pelos sujeitos e também estão presentes nos objetos.

Os sujeitos se relacionam com o seu entorno de forma a construir dialeticamente as ações que serão projetadas espacialmente. Deste relacionamento se constituiria uma conduta de ação, a qual se orienta para atingir uma determinada meta. As condicionantes do meio interferem sobre a materialidade da ação e, assim, nem tudo que foi intencionalizado se realiza do jeito que foi projetado, já que "à intencionalidade da ação se conjuga a intencionalidade dos objetos e ambas são, hoje, dependentes da respectiva carga de ciência e de técnica presente no território" (SANTOS, 2014, p. 94). Ou seja, "uma razão pela qual não se pode rever completamente o resultado da ação vem, exatamente, do fato de que a ação sempre se dá sobre o meio, combinação complexa e dinâmica, que tem o poder de deformar o impacto da ação" (SANTOS, 2014, p.95).

Neste sentido, as intencionalidades têm a capacidade de interferir sobre a materialização do sistema de ações e do sistema de objetos dentro do contexto espacial, sempre em uma perspectiva dialética.

Apesar das intencionalidades serem inter-relacionadas e apresentarem um resultado complexo sobre o espaço, quando adotamos uma visão analítica, é possível reconhecer as diferentes posições dos sujeitos e assim identificar os significados da presença deles no uso do território, por meio do entendimento das respectivas intencionalidades manifestadas.

O movimento de totalização, assim como entende Milton Santos (2014), pode ser identificado como outro elemento que nos auxilia no entendimento dos processos de mudança que ocorrem no espaço geográfico.

Os retratos dos movimentos históricos de uma dada configuração representam uma totalidade que ao longo do tempo permanecerá em uma constante transformação, a qual reflete o processo de totalização. Como Milton Santos adota a perspectiva de que o espaço geográfico é decorrente do processo de produção, a divisão internacional do trabalho seria a energia do movimento de totalização e, os eventos geográficos seriam os elementos que ligam os lugares a história que permanecem em movimento.

Para Milton Santos os subespaços fazem parte uma totalidade, sendo assim os territórios poderiam ser interligados por meio do acontecer solidário. Há assim uma interconexão entre os territórios pautada pelo acontecer solidário, o qual envolve o compartilhamento de atividades comuns e simultâneas, podendo se manifestar na forma de um acontecer homólogo, acontecer complementar ou acontecer hierárquico. 
O acontecer homólogo se manifesta em áreas de produção agrícola ou urbana, onde a informação especializada, decorrente da modernização, gera as contiguidades funcionais. Já o acontecer complementar seria próprio das relações entre a cidade e campo ou entre cidades, sendo que a complementariedade de funções aproxima as relações entre estes territórios. $\mathrm{O}$ acontecer hierárquico, por sua vez, é orientado por forças que são externas aos territórios e se manifestam através de um comando concentrado por uma organização que detém privilégios de informação. A informação em nosso período técnico-científico informacional adquire uma grande relevância por ter grande capacidade de influência sobre as relações de produção.

Jöel Bonnemaison, por sua vez, possibilita um entendimento mais expandido sobre a noção de território, lançando mão das contribuições da geografia cultural para a construção da noção dos significados do território em diferentes contextos. Segundo o autor, o território é ao mesmo tempo um espaço social que é produzido e um espaço cultural que é vivenciado, possuindo uma função social e uma função simbólica. E, desse modo, compreende que o território é um sistema e um símbolo: "um sistema porque se organiza e se hierarquiza para responder às necessidades e funções assumidas pelo o grupo que o constituiu. Um símbolo porque se forma em torno de polos geográficos representantes de valores políticos e religiosos que comandam a sua visão de mundo" (BONNEMAISON, 2012, p.290).

A partir deste entendimento sobre o espaço que considera os fatores culturais, Bonnemaison identifica a existência de três níveis no espaço estudado pelos geógrafos: o espaço estrutural, o espaço vivido e o espaço cultural.

O espaço estrutural está relacionado com a produção espacial das sociedades, a qual é decorrente de uma estruturação do espaço própria com o intuito de atender a determinadas finalidades e funções que estão imersas em um dado nível tecnológico. Por esta concepção, o “espaço do geográfico é formado por um conjunto de geoestruturas aplicadas ou encaixadas sobre os meios naturais, dos quais as paisagens são reveladoras" (BONNEMAISON, 2012, p. 292). Neste escopo de estudo encontraríamos a geografia social e econômica, a escola da paisagem e os geógrafos quantitativos.

Já no espaço vivido há uma preocupação com as dimensões subjetivas e existenciais, sendo assim, o espaço-estrutura seria vivido de formas diferentes a depender da sociedade. $\mathrm{O}$ cotidiano adquire um papel central nas análises que dispensam uma atenção especial sobre este nível.

O espaço cultural transcenderia o aspecto do vivido, porque nesse ocorreria as significações que decorrem dos processos de relação entre o homem com o espaço. Dessa 
forma, há uma preocupação especial em relação aos valores e símbolos que são projetados no território e, assim, o espaço cultural é "percebido como uma trama de territórios vivos, carregados de cultura, símbolos e afetividade” (BONNEMAISON, 2012, p293). Sendo assim, "existe um espaço objetivo, os das estruturas geográficas; mais adiante, um espaço subjetivo ou vivido; e, além, um espaço cultural, lugar de uma escritura geossimbólica" (BONNEMAISON, 2012, p.296).

Após discorrermos sobre as contribuições desses autores, entendemos que os processos territoriais possuem dimensões materiais, subjetivas e simbólicas, as quais adquirem diferentes significados conforme o contexto socioespacial. Quando aplicamos tais contribuições ao contexto do rural, conseguimos identificar os principais elementos que devem ser considerados na compressão do significado do desenvolvimento territorial rural.

Um dos primeiros elementos que podemos destacar é a perspectiva de que o desenvolvimento se caracteriza como um processo que está inserido dentro de uma totalidade. Como discutido no capítulo anterior, a concepção de desenvolvimento de nossa contemporaneidade que se associa a noção de sustentabilidade, pressupõe o alcance de um estágio de coisas diferente do atual onde o meio natural deixa de ser considerado como um mero insumo dos processos produtivos.

O rural não está isolado dos processos que agem sobre a nossa contemporaneidade, e nem tão pouco se coloca como um agente passivo diante deste processo. Os discursos sobre o desenvolvimento sustentável e, mais recentemente, a consolidação da agroecologia como um campo de saber, têm modificado os conteúdos das relações que se transcorrem no espaço rural. Todavia, devemos considerar que o rural possui uma identidade própria determinada pelos fatores culturais e sociais de cada localidade. Sendo assim, a realidade dos diferentes espaços rurais interfere sobre como os processos externos de desenvolvimento serão incorporados.

O exercício de entender como cada localidade rural reage aos processos de desenvolvimento pode ser frutífero quando consideramos a existência de níveis no espaço, assim como percebe Jöel Bonnemaison. A identidade do espaço rural não se relaciona somente com o caráter das atividades produtivas; as relações sociais centradas na família, os valores compartilhados em uma cultura comunitária e a identificação com os ciclos da natureza, são elementos que permeiam a constituição da identidade rural própria a cada localidade. 
Neste sentido, o território rural possui uma função social e uma função simbólica. $\mathrm{O}$ território se constitui, de forma organizada, para responder às necessidades econômicas, sociais e funcionais de um determinado grupo. Mas o território rural também é a representação dos valores políticos, culturais e religiosos, os quais tenderão a influenciar a perspectiva existente entre seus membros sobre a relação do homem com a natureza.

Os diversos territórios rurais possuem também seus respectivos sistemas territoriais que em nossa contemporaneidade serão influenciados pelo contexto de modernidade. A identificação dos atores de um dado sistema territorial é de extrema importância para que seja entendido como as relações tem afetado a territorialidade. Conseguimos identificar uma pluralidade de atores nos espaços rurais contemporâneos, dentre os quais estão os tradicionais agricultores familiares, o poder público - representado por diversas instituições -, famílias que usufruem dos atrativos naturais do rural, agricultores patronais, donos de grandes empreendimentos agrícolas e empreendimentos ligados às atividades turísticas.

Neste sentido, não só agricultores têm se interessado pelo rural de nossa contemporaneidade. Discutimos nos capítulos anteriores que o rural não deve ser compreendido por uma perspectiva unidimensional, ele não é mais apenas um lugar para produção restrita de alimentos. Os diferentes atores que citamos representam interesses que nem sempre são convergentes sobre o rural. A pluralidade de interesses interfere sobre as intencionalidades que afetarão o uso do território.

As modificações sobre as formas-conteúdo dos territórios rurais são decorrentes do uso destes ao longo do tempo. Em nossa contemporaneidade não esperamos mais dos espaços rurais apenas funções produtivas. Os territórios rurais começam a abrigar diferentes atividades devido aos novos significados sobre o uso destes territórios.

É crescente o reconhecimento de que as questões ambientais devem permear os diferentes aspectos da vida humana para que assim haja um ambiente favorável à construção de uma relação do homem coma natureza mais harmônica. Neste sentido, os territórios rurais devem também abrigar atividades que contribuam para o contexto de desenvolvimento sustentável.

Os atores pertencentes a um dado território possuem capacidades para interferir sobre o curso dos processos que transformarão o território. Sendo assim, os atores dos territórios rurais podem construir contextos territoriais onde a dimensão ambiental seja valoriza. 
Há reconhecimento de que o rural vem sofrendo profundas transformações em nossa modernidade. A agricultura familiar tem sido identificada como um importante ator que imputa novos significados aos territórios rurais.

O discurso da abordagem de desenvolvimento rural, que valoriza a agricultura familiar e seus aspectos territoriais, reconhece que a agricultura familiar teria em si um aspecto multifuncional e, neste sentido, as contribuições deste grupo social estão para além da simples produção de alimentos.

A multifuncionalidade da agricultura familiar teve os seus limites conceituais construídos dentro de duas arenas de debates; uma se refere aos significados do desenvolvimento sustentável, e neste sentido, corrobora para a ampliação do olhar sobre o espaço rural para além de sua capacidade econômica, e outra que diz respeito às contribuições da agricultura familiar em produzir externalidades positivas ao meio, devido a um modo de produção diferenciado (ABRAMOVAY, 2009). Segundo Sabourin, "a partir da conferência Eco 92, a multifuncionalidade foi caracterizada como o reconhecimento pela sociedade do interesse público ou geral de funções sociais, ambientais, econômicas ou culturais, não diretamente produtivas ou não mercantis e associadas à atividade agropecuária" (SABOURIN, 2008).

As funções desempenhadas pela agricultura familiar seriam: permitir a reprodução socioeconômica das famílias rurais; garantir a segurança alimentar das famílias rurais e da sociedade como um todo; contribuir para a manutenção do tecido social e das práticas culturais; e exercer um importante papel na preservação dos recursos naturais e da paisagem rural.

Quando lançamos mão de uma visão geográfica sobre o território, reconhecemos que a agricultura familiar é um importante ator que pode interferir sobre o uso do território. Contudo, como discutido, o território não é passivo, está imerso em um determinado contexto e é modificado pela ação de diversos atores e processos que se transcorrem ao longo do tempo. Sendo assim, a multifuncionalidade do território rural ocorrerá não somente pela atuação isolada da agricultura familiar. Outros elementos devem ser considerados na análise das funções dos territórios rurais.

Nesse sentido, entendemos que o desenvolvimento rural deve ser reconhecido através de uma perspectiva processual, onde o território exerce um importante papel no curso do desenvolvimento. Além disso, identificamos que os processos de desenvolvimento podem 
carregar o conteúdo sustentável, conforme princípios da agroecologia, a depender dos interesses dos atores presentes no território, dentre os quais está a agricultura familiar.

Após discorremos sobre as contribuições da agroecologia e das noções de território e territorialidade da geografia para a compreensão dos processos de desenvolvimento rural, no capítulo a seguir analisaremos os conteúdos estudados a partir de um caso concreto. Dessa forma, o último capítulo desta dissertação se preocupa em verificar empiricamente como a agroecologia, difundida nas ações da Emater-DF, tem influenciado em uma perspectiva territorial os agricultores de Brazlândia. 


\section{As implicações das ações de práticas agrícolas sustentáveis da Emater-DF sobre o desenvolvimento territorial rural de Brazlândia}

O presente capítulo se propõe a analisar, a partir de dados secundários e dados primário obtidos por meio de entrevistas, a influência da Emater-DF sobre a incorporação de práticas agrícolas sustentáveis no território rural de Brazlândia. Neste sentido, o capítulo é composto por duas seções: a primeira aborda o contexto socioespacial de Brazlândia e a segunda é composta pelas análises dos dados coletados pelas entrevistas de campo. Ainda na segunda seção, também é discutido de que forma as práticas agrícolas tem sido e podem ser incorporadas pelos agricultores de Brazândia, apontado o papel que a Emater-DF tem neste processo.

\subsection{Contextualização Geográfica de Brazlândia}

O retrato atual do contexto socioespacial de Brazlândia é a expressão de diferentes processos que ocorreram em diferentes escalas. Com intuito de identificar e compreender os processos que influenciaram a constituição do território de Brazlândia ao longo do tempo, vamos recorrer a três escalas analíticas. A primeira se refere à modernização agrícola dirigida à região Centro-Oeste; na segunda são evidenciados os principais fatores que afetaram o ordenamento territorial do meio rural do Distrito Federal; e, por último, nos focamos na descrição da constituição de Brazlândia e suas características, no que se refere o rural abrangido por esta Região Administrativa do Distrito Federal.

\subsubsection{Modernização Agrícola Dirigida a Região do Centro-Oeste}

A região do Centro-Oeste não ficou à parte dos processos de modernização agrícola dirigidos para o campo do Brasil como um todo, contudo teve algumas especificidades próprias decorrentes das políticas empregadas para região. Silva (2008) analisa o processo de modernização agrícola no contexto da região do Centro -Oeste, considerando os fatores socioeconômicos, as ações de gestão do território e os seus resultados. A partir desta análise, o autor estabelece a existência de quatro fases que sintetizam as principais mudanças ocorridas na região no que tange o desenvolvimento agrícola.

A primeira fase corresponde ao Início do Processo de Modernização da Agricultura, compreendendo os anos de 1956 a 1969. Nesta fase é possível perceber um forte interesse do Estado para que a região se inserisse no cenário econômico nacional e internacional, adotando-se como estratégia principal a mecanização da agricultura. 
As políticas deste período buscavam a expansão da fronteira agrícola para o cerrado com o intuito de aumentar a oferta de gêneros alimentícios e de matérias primas e, assim, suprir a demanda do mercado consumidor e a indústria emergente da região sudeste.

Vale ressaltar que o evento da transferência da capital para Brasília trouxe um maior dinamismo econômico para região e favoreceu a integração do território nacional por meio da criação de grandes eixos viários. Ademais, também é observado nesta primeira fase, a intensão por parte do Estado de incentivar a migração populacional para região central do país.

Neste período, houve um aumento da produção agrícola, justificado mais pela oferta de terras do que pelo incremento tecnológico nas práticas de cultivo que ainda tinham baixa produtividade. As técnicas de cultivo deste momento ainda não eram adequadas ao solo ácido e pouco fértil do cerrado. Silva (2008) aponta que as políticas do período não eram devidamente articuladas e não se adequavam às especificidades da região, o que acarretou uma ocupação desorganizada e o início da intensificação da degradação ambiental.

A segunda fase é denominada, por Silva (2008), de Constituição dos Complexos Agroindustriais - CAIS e corresponde aos anos de 1970 a 1985. A decadência dos projetos econômicos de ocupação da região amazônica do país, daquele período, desloca a atenção política para o Centro - Oeste que adquire uma maior centralidade nas políticas de desenvolvimento. Assim são elaborados diversos planos ${ }^{15}$ que tinham o propósito de trazer um desenvolvimento econômico para região do Centro - Oeste. As políticas pertencentes a estes planos apresentaram dentre seus objetivos: incentivar a atividade agropecuária com vistas à exportação e promover a ocupação da populacional da região.

Nesta fase, a modernização da agricultura do Centro - Oeste ocorreu através de uma série de políticas concertadas, contribuindo para que a região se tornasse o celeiro de produção de grão do país. O aumento expressivo da produção agrícola durante o período foi decorrente de três principais fatores: o fomento a pesquisas para o desenvolvimento de técnicas agrícolas para fertilidade do solo da região; créditos subsidiados; e a política de preços mínimos.

Como resultados deste processo, encontramos: a expansão da soja, o aumento da produtividade agrícola; constituição dos complexos agroindustriais; aumento da concentração

\footnotetext{
${ }^{15}$ Programa de Desenvolvimento do Centro - Oeste - Prodoeste (1972), Plano de Desenvolvimento Econômico e Social do Centro - Oeste - Pladesco(1972); Programa de Desenvolvimento do Pantanal - Prodepan (1972); Programa de Desenvolvimento dos Cerrados - Polocentro (1975); Programa de Desenvolvimento Rural Integrado do Noroeste do Brasil - Polonoroeste (1981) e Programa de Cooperação Nipo- Brasileira para o Desenvolvimento dos Cerrados - Prodecer (1974).
} 
de terras; e intensificação da degradação ambiental com perda da cobertura vegetal do bioma cerrado.

Vale ressaltar que o modelo produtivo agrícola incentivado neste período acarretou o processo de perda de terras por parte dos pequenos agricultores, que não conseguiram se adaptar ao novo contexto de desenvolvimento agrícola.

A terceira fase foi reconhecida por Silva (2008) como sendo a Constituição dos Complexos Agroindustriais de Grãos e Carne. Tal fase abrange os anos de 1982 a 2002 e nela se observa uma transnacionalização e globalização dos CAIS que se expandem e são transformados em Complexos Agroinstrustriais de Grãos e Carne.

Não há apenas o interesse estatal na gestão do território, os interesses privados e internacionais ganham relevância na condução dos processos de desenvolvimento agrícola da região. Silva (2008) ressalta que as ações do Estado acabam por ser moldadas pelos interesses do mercado em sua abrangência global. Observa-se nesta fase a ampliação da rede viária e logística, a difusão de pacotes técnicos e tecnológicos e a crescente degradação ambiental do bioma do cerrado.

A última fase identificada por Silva (2008) corresponde à Constituição de uma Agricultura voltada para a Produção de Combustíveis e se refere aos anos de 2003 a 2007. Dentre as principais características desta fase podemos pontuar o incentivo por parte do Estado e de investimentos internacionais na produção de agrocombustíveis, decorrente de uma necessidade do mercado associada a uma vontade política do Estado. O fomento ao cultivo de soja destinada à produção de biodiesel e ao cultivo de cana-de-açúcar destinada à produção de álcool combustível, etanol.

$\mathrm{Na}$ região do Centro-Oeste, no momento atual, encontram-se grandes empreendimentos agrícolas de produção de grãos, carnes e agrocombustíveis voltados para o mercado internacional. Esta estrutura produtiva agrícola é decorrente do processo de mundialização da agricultura, estudado por Oliveira (2012), o qual impacta diretamente sobre o espaço rural, nos quais são manifestados a monopolização dos territórios e os territórios monopolizados.

No contexto atual, onde observamos a produção crescente de commodities, a comercialização em bolsa de mercadorias e futuros e o fortalecimento dos monopólios mundiais, a mundialização atua sobre a agricultura por meio dos processos de territorialização dos monopólios e monopolização dos territórios. O primeiro age sobre controle da propriedade privada da terra, do processo produtivo da terra e do processamento industrial da 
produção agropecuária. Já a monopolização dos territórios, se dá pelas grandes empresas de comercialização e processamento industrial que controlam fazendeiros capitalistas e camponeses, sem, contudo, produzirem no campo. Tais empresas também atuam na produção de agrotóxicos e fertilizantes (OLIVEIRA, 2012).

Como resultado da territorialização dos monopólios na agricultura, temos um entrelaçamento ainda maior do capital nacional com o estrangeiro. $\mathrm{Na}$ realidade do agronegócio brasileiro, as grandes empresas mundiais se associaram as empresas nacionais dos setores sucroenergético, celulose e madeira plantada.

\subsubsection{Ordenamento territorial do meio rural do Distrito Federal}

Tendo em vista o desenvolvimento agrícola para região do Centro-Oeste, partiremos agora para análise do ordenamento territorial do Distrito Federal. O ordenamento territorial do espaço rural do Distrito Federal foi impactado tanto pelas políticas desenvolvimentistas para a modernização da agricultura da região Centro-Oeste quanto pelas estratégias de consolidação da nova Capital no planalto central como um espaço capaz de integrar a região ao processo produtivo do país.

Até a transferência da capital, a região era ocupada por pequenos agricultores que desenvolviam atividades agrícolas de subsistência e de baixa produtividade. Vale ressaltar que naquele momento a modernização da agricultura não havia se estendido de modo a causar modificações sobre a região da nova capital. No final da década de 1950 e durante a década de 1960, o espaço da nova capital federal ainda estava diretamente submetido as suas próprias políticas de ordenamento territorial.

A organização fundiária do Distrito Federal foi iniciada pela promulgação da Lei $n^{\circ}$ 2.874 de 1956, que criou a Companhia Urbanizadora da Nova Capital (Novacap), desde então os instrumentos legais passariam a exercer influência sobre os espaços urbano e rural. No que se refere ao contexto rural, as terras desapropriadas passariam a ser exploradas por meio da concessão de contratos de arrendamentos, nos quais os agricultores desenvolveriam atividades agrícolas de acordo com os propósitos do Estado para o uso econômica das terras.

O processo de arredamento foi inicialmente realizado pelo Departamento de Terras e Agricultura instituído em 1957, ligado à Novacap, mas, posteriormente, este departamento ganhou autonomia institucional e se transformou na Superintendência de Agricultura e Produção - SAP. A Fundação Zoobotânica do Distrito Federal (FZDF), instituída em 1961, se 
constituiu no órgão executor da implantação e desenvolvimento da política agropecuária formulada pela SAP (OLIVEIRA, 2006).

Com intuito de fomentar a produção de gêneros alimentícios no volume adequado às necessidades do mercado consumidor da Capital Federal, foram criados os Núcleos Rurais e as Colônias Agrícolas, os quais comporiam uma espécie de cinturão verde para o abastecimento de alimentos.

O espaço rural do DF foi concebido, pelas políticas agrícolas dos anos iniciais da implantação da nova capital, como um espaço que deveria abrigar uma agricultura de abastecimento. Segundo Rebelo Junior, esta agricultura de abastecimento "deveria tanto prover a subsistência do agricultor, como a obtenção do lucro", e ainda "deveria abastecer o agricultor e o Distrito Federal” (REBELO JUNIOR, 1992, p.44)

A partir de 1970, devido ao processo da modernização agrícola, as áreas rurais da região do Distrito Federal adquirem um significado estratégico para o projeto desenvolvimentista do país como um todo daquela época. Dessa forma, foi deixado em segundo plano o projeto de estruturação de uma agricultura para o abastecimento, a qual envolvia o incentivo a estabelecimentos de pequeno porte arrendados e geridos pela lógica familiar de produção agrícola.

Neste sentido, na região da nova capital passaram a ser fomentadas políticas que favoreciam a implantação de grande lavouras, acompanhando assim a tendência das políticas destinadas a escala maior do Centro -Oeste. E assim, as diretrizes que circundavam o projeto de modernização do campo passaram a ser inseridas no contexto agrícola do Distrito Federal.

Em 1972, por meio da Lei 5.861/1972, foi permitida a alienação de terras rurais a pessoas físicas ou jurídicas de direito privado, abrindo-se espaço para implantação das grandes propriedade destinadas à produção de monoculturas e agropecuária. O Plano Agrário do Distrito Federal para os anos de 1971-1973 transparece as intenções de desenvolvimento agrário daquele período ao definir como objetivo: "aumentar a produção agropecuária, de modo a incrementar a participação da produção interna na oferta global de produtos agropecuários e acompanhar o aumento da demanda, através de investimentos programados, complementados por instrumentos de política econômica, social, agropecuária e institucional" (CODEPLAN, 2015a, p. 32). Neste contexto, a agricultura no Distrito Federal deveria se conformar em propriedades de grande porte, com elevados índices de produtividade e voltadas para o mercado global. 
Neste contexto foram criadas as Áreas Isoladas destinadas a implantação de grandes projetos agropecuários. Nestas áreas especiais também eram desenvolvidos pesquisas experimentais e estudos específicos para a exploração de culturas levando em consideração as características do solo do cerrado.

A implementação do Programa de Assentamento Dirigido do Distrito Federal (PADDF) foi uma das principais inciativas governamentais que tinha o intuito de fomentar práticas agrícolas mais rentáveis em grandes propriedades, estimulando a mecanização e o uso intensivo de insumos modernos. E assim:

O governo proveu de infraestrutura, crédito e tecnologia as grandes unidades rurais, visando o desenvolvimento de uma agropecuária inserida no mercado que utilizasse insumos industrializados e tecnologia. A escolha do modelo produtivo induziu à seleção de arrendatários originários da Região Sul, em especial os dotados de tradição e experiência em sistemas cooperativistas e tecnologias modernas (CODEPLAN, 2015a, p.33)

É possível observar que naquele momento havia a concorrência entre dois modelos agrícolas. Um compreendia a agricultura voltada ao mercado e pautada pelas grandes lavouras de monocultura que incorporava as técnicas difundidas pelas pesquisas direcionadas pela modernização da agricultura. O outro modelo correspondia à agricultura destinada à produção de alimentos para o núcleo urbano da nova capital. No momento da transferência da capital observa-se uma intenção por parte do poder público de fomentar a consolidação das pequenas propriedades produtoras de alimentos, mas esse projeto perdeu força com a intensificação do processo de modernização agrícola dos anos 1970. Algo que pode ser observado pela evolução da estrutura fundiária do Distrito Federal

O Gráfico 2 representa a evolução da área média das propriedades rurais do Distrito Federal. Observamos que há um aumento expressivo no tamanho das áreas médias dos estabelecimentos no período entre 1970 e 1980, onde houve a estruturação de ações que beneficiaram a consolidação do modelo produtivo agrícola destinado à grande propriedade. A partir de 1995 observamos uma queda considerável na área média dos estabelecimentos rurais do Distrito Federal, fator que pode ser explicado pela estruturação de ações de valorização aos pequenos produtores a partir deste período. As ações de valorização ao agricultor familiar compreenderam: i) inciativas de ordenamento fundiário, como os decretos $n^{\circ} 17.502$ de 10/07/1996 e no 19.248 de 19/05/1998, ii) adequação da legislação ao perfil dos pequenos produtores, iii) programas de incentivo a agroindustrialização, iv) apoio a comercialização e v) crédito agrícola. (CARVALHO, 1998). 
Vale ressaltar que em meados da década de 1990 o governo do Distrito Federal passou a ter uma atenção especial para com os agricultores familiares. As políticas agrícolas deste período passaram a ser pautadas "na perspectiva de alavancar e dinamizar o sistema produtivo agropecuário e agroindustrial do DF" através da inclusão "no processo de desenvolvimento os segmentos até então excluídos" (CARVALHO, p. 21, 1998)

Gráfico 2 - Evolução das áreas médias em ha dos estabelecimentos agropecuários, Brasil e Distrito Federal - 1970/2006

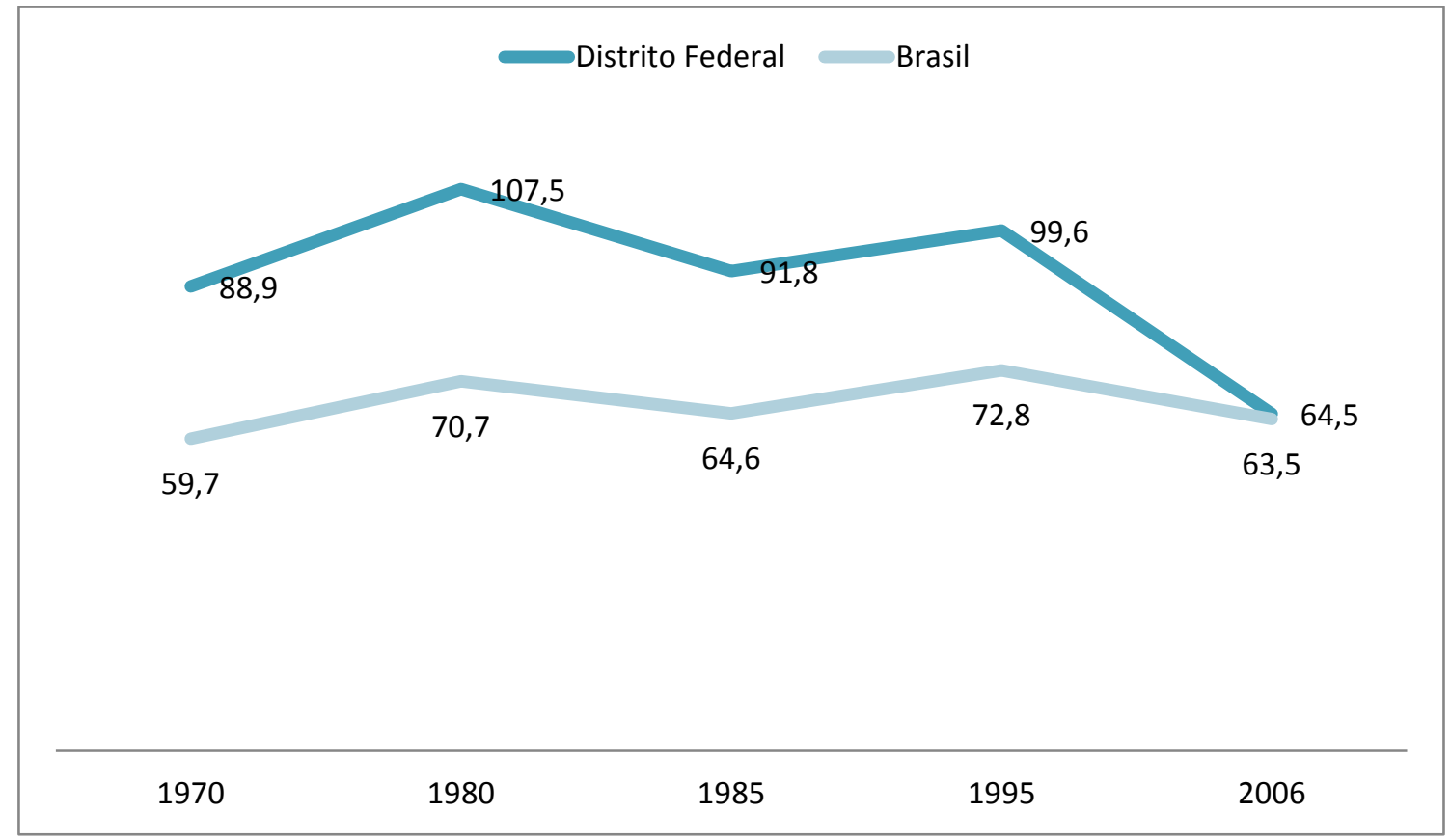

Fonte: Codeplan, 2015a

Os modelos agrícolas estimulados naquela época permanecem até hoje retratados no ordenamento territorial da região de Brasília. Por meio da tabela 3, conseguimos perceber que a estrutura fundiária do DF é bem concentrada. Apesar de agricultura familiar representar algo perto de metade dos estabelecimentos agropecuários, ela ocupa apenas 4,3\% do total de área, sendo que esta proporção é bem menor do que a do Brasil como um todo.

Tabela 3 - Número, área total e área média dos estabelecimentos agropecuários, compreendidos pelas modalidades de agricultura familiar e não familiar - Brasil e Distrito Federal - 2006

\begin{tabular}{l|c|c|c|c|c}
\hline \multirow{2}{*}{$\begin{array}{c}\text { Modalidade de } \\
\text { Agricultura - Lei } \\
\mathbf{1 1 . 3 2 6 / 2 0 0 6}\end{array}$} & \multicolumn{2}{|c|}{$\begin{array}{c}\text { Total de } \\
\text { estabelecimentos }\end{array}$} & \multicolumn{2}{c|}{ Área Total } & \multicolumn{2}{c}{$\begin{array}{c}\text { Área Média dos } \\
\text { estabelecimentos }\end{array}$} \\
\cline { 2 - 6 } & Número & $\%$ & Hectares & $\%$ & ha/Estab. \\
\hline Brasil & 5.175 .489 & 100 & $329.941 .393,30$ & 100 & 63,8 \\
\hline Familiar & 4.367 .902 & 84,4 & $80.250 .453,10$ & 24,3 & 18,4 \\
\hline
\end{tabular}




\begin{tabular}{l|c|c|c|c|c} 
Não Familiar & 807.587 & 15,6 & $249.690 .940,20$ & 75,7 & 309,2 \\
\hline Distrito Federal & 3.955 & 100 & $251.319,80$ & 100 & 63,5 \\
\hline Familiar & 1.824 & 46,1 & $10.867,20$ & 4,3 & 6 \\
\hline Não Familiar & 2.131 & 53,9 & $240.452,60$ & 95,7 & 112,8 \\
\hline
\end{tabular}

Fonte: Codeplan, 2015a

A produção de grandes culturas (soja, feijão, milho, café, trigo e outras) tem tido um destaque nos últimos anos no Distrito Federal. Entre os anos de 2003 e 2013 houve um aumento da área incorporada por essas lavouras, acompanhado do aumento de produtividade. Segundo a Codeplan (2015a), neste período a área ocupada por estas culturas aumentou $45,57 \%$ e a produção teve um aumento de 120,57\%, chegando em 2013 a 842,60 milhões de toneladas. Podemos observar que o uso do solo destinado a grandes culturas ocupa uma proporção relevante que corresponde a $34,1 \%$ (Tabela 4)

Tabela 4 - Uso Atual do Solo no Distrito Federal -2013

\begin{tabular}{l|c|c}
\hline Tipos de cultivo & Área (ha) $\mathbf{2 0 1 3}$ & $\boldsymbol{\%}$ \\
\hline Cultivos (Inverno/Verão) & $155.444,67$ & 36,89188 \\
\hline Grandes Culturas: & $143.694,43$ & 34,10318 \\
\hline . Grãos & $129.441,00$ & 30,7204 \\
\hline . Outras & $14.253,41$ & 3,38278 \\
\hline Hortaliças & $8.679,85$ & 2,06 \\
\hline Cultivos Permanentes & - & \\
\hline . Frutíferas (Form. + Prod.) & $1.364,63$ & 0,323869 \\
\hline . Café (Form. + Prod.) & - & \\
\hline Floricultura & 565,2 & 0,13414 \\
\hline Silvicultura & $2.505,19$ & 0,59456 \\
\hline Pastagens & $144.100,10$ & 34,19946 \\
\hline Reservas & $90.445,98$ & 21,46566 \\
\hline Preservação & $43.290,32$ & 10,27415 \\
\hline Outras & $56.036,10$ & 13,29912 \\
\hline Área Rural Total & $421.352,00$ & 100 \\
\hline
\end{tabular}

Fonte: Codeplan, 2015a

Dado este panorama, no contexto rural do Distrito Federal, encontramos o desenvolvimento de dois modelos de agricultura, cujas origens podem ser percebidas nas políticas do ordenamento do espaço rural que seria ocupado pela nova capital. Um dos modelos volta-se prioritariamente para o mercado externo e foi impulsionado pela modernização agrícola. O outro modelo se constitui, prioritariamente, para garantir o abastecimento de alimentos ao centro urbano da nova capital.

Atualmente, as regiões administrativas do DF que possuem uma maior presença de agricultores familiares e, sendo assim, abrigam o desenvolvimento do modelo de produção 
familiar, são as regiões de Brazlândia, Planaltina, Gama, São Sebastião e Ceilândia. Estas regiões abrigam $66 \%$ da população rural do DF, sendo que Brazlândia e Planaltina se destacam com mais 30\% desse montante (CODEPLAN, 2015a).

\subsubsection{Brazlândia e as características de seu território rural}

A presente pesquisa concentrou suas análises em Brazlândia, um dos motivos foram as fortes características rurais desta Região Administrativa do DF. Apesar da vocação rural de Brazlândia remontar as funções de seu território no momento em que chegaram as primeiras famílias para ocupar a região, a transferência da capital para o planalto central consolidou a importância de Brazlândia como fornecedora de alimentos.

A projeção do Estado nos anos iniciais da instituição da nova capital sobre o que deveria ser o espaço rural de Brazlândia pode ser percebida até os dias de hoje. A região abriga 787 estabelecimentos rurais, este número representa $20 \%$ do número total de estabelecimentos rurais do Distrito Federal, sendo que Brazlândia é a segunda RA com maior número de estabelecimentos, ficando atrás apenas de Planaltina que possui $34 \%$ do total de estabelecimentos. A maioria dos estabelecimentos rurais de Brazlândia $(56,3 \%)$ se enquadram como sendo de agricultores familiares, conforme os critérios da Lei 11.326/2006 ${ }^{16}$.

Atualmente Brazlândia se destaca pela produção agrícola, 2.485,37 hectares de sua área de abrangência são destinados à produção de hortaliças, 867,06 hectares à produção de grandes culturas e 395,48 hectares à produção de frutas. As hortaliças e as frutas representam $29,61 \%$ e 30,35\%, respectivamente, de toda a produção destes gêneros no DF. A partir das informações da tabela abaixo conseguimos observar os principais dados da produção agrícola de Brazlândia e a sua comparação com a produção agrícola do DF como um todo.

\section{Tabela 5 - Produção de Frutas - Brazlândia}

\begin{tabular}{l|r|r|r|r}
\hline \multicolumn{1}{c|}{ Gênero } & Área (ha) & Participação no DF (\%) & Produção (t) & Participação no DF (\%) \\
\hline Goiaba & 201,3 & 84,23 & $6.144,98$ & 86,9 \\
\hline Banana & 26,36 & 13,87 & 527,55 & 14,26 \\
\hline Tangerina & 22 & 16,18 & 375 & 12,09 \\
\hline Maracujá & 11,25 & 9,38 & 316,22 & 9,05 \\
\hline Limão & 43,36 & 18,14 & 512,65 & 7,57 \\
\hline Outras & 91,21 & 27,35 & $2.117,60$ & 29,61 \\
\hline Total & $\mathbf{3 9 5 , 4 8}$ & $\mathbf{2 3 , 1 5}$ & $\mathbf{9 9 9 4}$ & $\mathbf{2 6 , 9 3}$ \\
\hline
\end{tabular}

Fonte: Informações Agropecuárias do Distrito Federal, 2013, Emater-DF.

\footnotetext{
${ }^{16}$ A Lei 11.326/2006 dispõe sobre as características dos empreendimentos que podem ser considerados de agricultura familiar. Segundo a lei, os estabelecimentos devem possuir no máximo quatro módulos fiscais, utilizar predominantemente a mão de obra da própria família, as atividades desenvolvidas no estabelecimento devem contribuir para renda familiar e a família deve ser a responsável pela gestão do empreendimento.
} 
Tabela 6 - Produção de Hortaliças - Brazlândia

\begin{tabular}{l|r|r|r|r}
\hline \multicolumn{1}{c|}{ Gênero } & Área (ha) & Participação no DF $(\%)$ & \multicolumn{1}{c}{ Produção $(\mathrm{t})$} & Participação no DF (\%) \\
\hline Morango & 200,6 & 100 & $6.666,55$ & 100 \\
\hline Beterraba & 173,3 & 63,46 & $3.806,00$ & 63,27 \\
\hline Alface & 657,25 & 52,12 & $13.543,42$ & 51,62 \\
\hline Repolho & 115,03 & 46,33 & $6.001,20$ & 47,03 \\
\hline Cenoura & 100,7 & 32,63 & $2.531,40$ & 30,53 \\
\hline Milho-verde & 100,25 & 17,26 & $2.298,34$ & 19,85 \\
\hline Tomate & 105,3 & 13,64 & $7.100,50$ & 14,71 \\
\hline Pimentão & 53 & 23,79 & $2.570,00$ & 14,01 \\
\hline Batata & 8,7 & 12,3 & 291 & 10,57 \\
\hline Outras & 971,24 & 21,26 & $30.648,17$ & 28,46 \\
\hline Total & $\mathbf{2 4 8 5 , 3 7}$ & $\mathbf{2 9 , 2 2}$ & $\mathbf{7 5 4 5 6 , 5 8}$ & $\mathbf{3 0 , 3 5}$ \\
\hline
\end{tabular}

Fonte: Informações Agropecuárias do Distrito Federal, 2013, Emater-DF.

Tabela 7 - Produção de Grandes Culturas - Brazlândia

\begin{tabular}{l|r|r|r|r}
\multicolumn{1}{c|}{ Gênero } & Área (ha) & Participação no DF (\%) & Produção (t) & \multicolumn{1}{c}{ Participação no DF (\%) } \\
\hline Milho & 566,26 & 1,06 & $2.282,56$ & 0,54 \\
\hline Feijão & 67,8 & 0,41 & 102,5 & 0,41 \\
\hline Outras & 233 & 2,02 & $3.435,00$ & 1,7 \\
\hline Total & $\mathbf{8 6 7 , 0 6}$ & $\mathbf{0 , 6}$ & $\mathbf{5 8 2 0 , 0 6}$ & $\mathbf{0 , 6 9}$ \\
\hline
\end{tabular}

Fonte: Informações Agropecuárias do Distrito Federal, 2013, Emater-DF.

A Região de Brazlândia também é de grande interesse ambiental por abrigar relevante diversidade biológica e bacias hidrográficas essenciais para o abastecimento de água da região, fazendo com o uso do seu território seja diretamente impacto pelas políticas de conservação ambiental. Neste sentido, abriga uma diversidade de Unidades de Conservação de Uso Sustentável e de Proteção Integral, sendo elas: Floresta Nacional de Brasília, Parque Nacional de Brasília, Parque Ecológico Veredinha, Área de Proteção Ambiental de Cafuringa, Área de Proteção do Rio Descoberto e as Áreas de Proteção de Mananciais Barrocão, Chapão da Onça, Santa Maria, Ribeirão das Pedras e Barragem do Descoberto. As unidades de conservação de Brazlândia foram criadas, em sua maioria, a partir da década de 1980. Com a criação dessas unidades famílias que anteriormente ocupavam tais áreas tiveram as suas atividades restringidas, e em algumas situações tiveram que ser realocadas. Neste sentido, após a criação dessas unidades sugiram conflitos socioambientais decorrentes das alterações sobre os padrões utilização do solo regulados pelo poder público. Além disso, há dificuldades 
de se ter acesso a terra através dos mecanismos legais devido a pouca clareza quanto ao processo de regularização fundiária (COSTA, 2015).

O macrozoneamento da região, que indica as funcionalidades relacionadas ao uso do solo, aponta que uma parcela significativa da área total de Brazlândia se refere às zonas rural e de proteção ambiental integral. Dessa forma, as funcionalidades do território ligadas ao rural e a proteção ambiental possuem um destaque considerável no caso de Brazlândia. Por isso, além da importância da produção agrícola, as belezas naturais desta RA do Distrito Federal apresenta um grande potencial turístico.

\section{Tabela 8 - Áreas Territoriais - Brazlândia}

\begin{tabular}{c|c|c|c|c|c|c|c}
\hline $\begin{array}{c}\text { Zona Urbana } \\
\text { (ha) }\end{array}$ & $\%$ & $\begin{array}{c}\text { Zona Rural } \\
\text { (ha) }\end{array}$ & $\%$ & $\begin{array}{c}\text { Zona de Proteção } \\
\text { Integral (ha) }\end{array}$ & $\%$ & Total & $\%$ \\
\hline $\mathbf{6 9 5 , 7 5}$ & 1,45 & $36.099,91$ & 75,71 & \multicolumn{1}{c}{$10.889,18$} & 22,84 & $47.684,84$ & 100 \\
\hline
\end{tabular}

Figura 1 - Macrozoneamento de Brazlândia

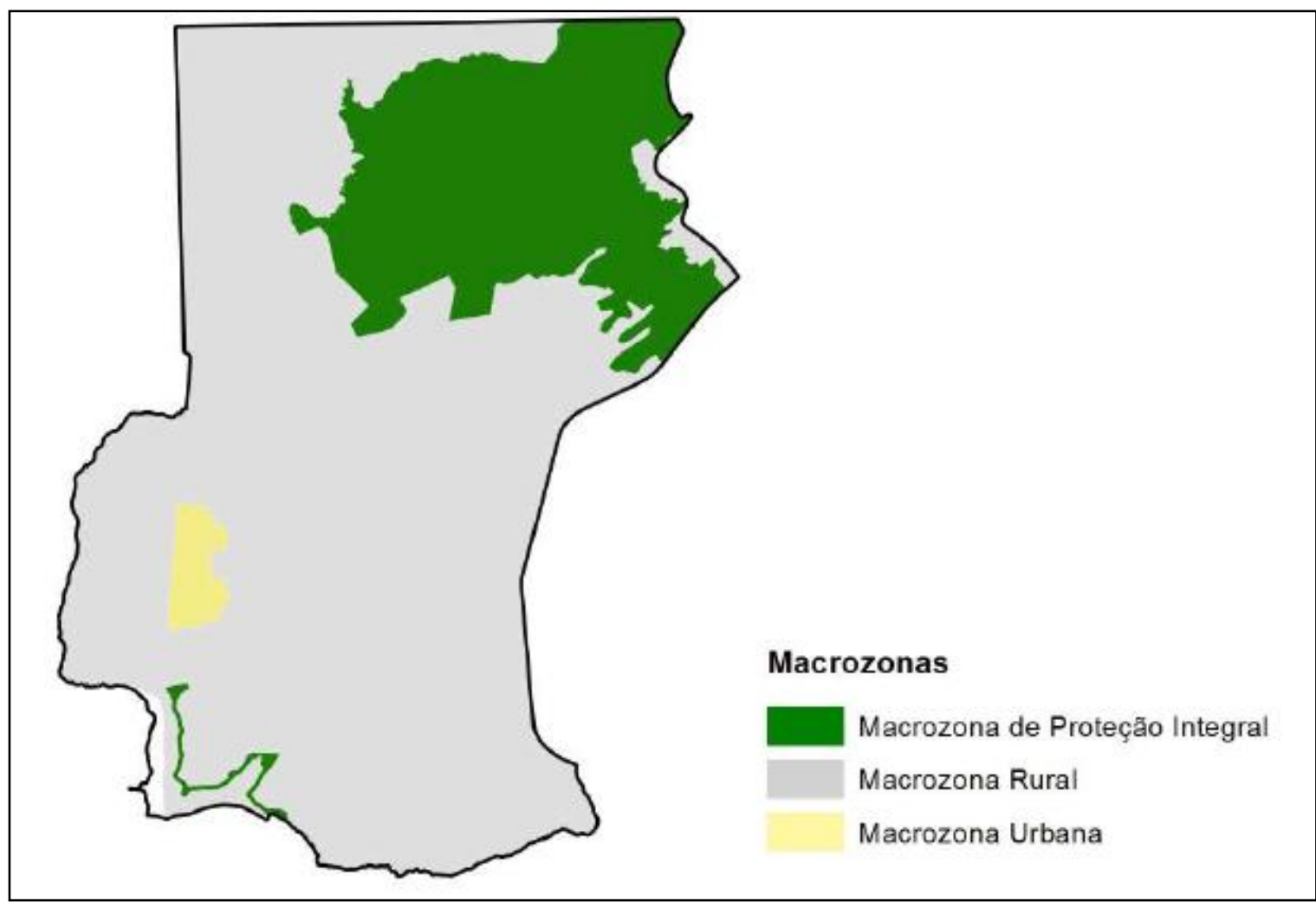

Fonte: Codeplan, 2015d, Zoneamento Territorial PDOT- LC n ${ }^{\circ} 854$ de 15 de outubro de 2012. 
Figura 2 - Localização de Brazlândia

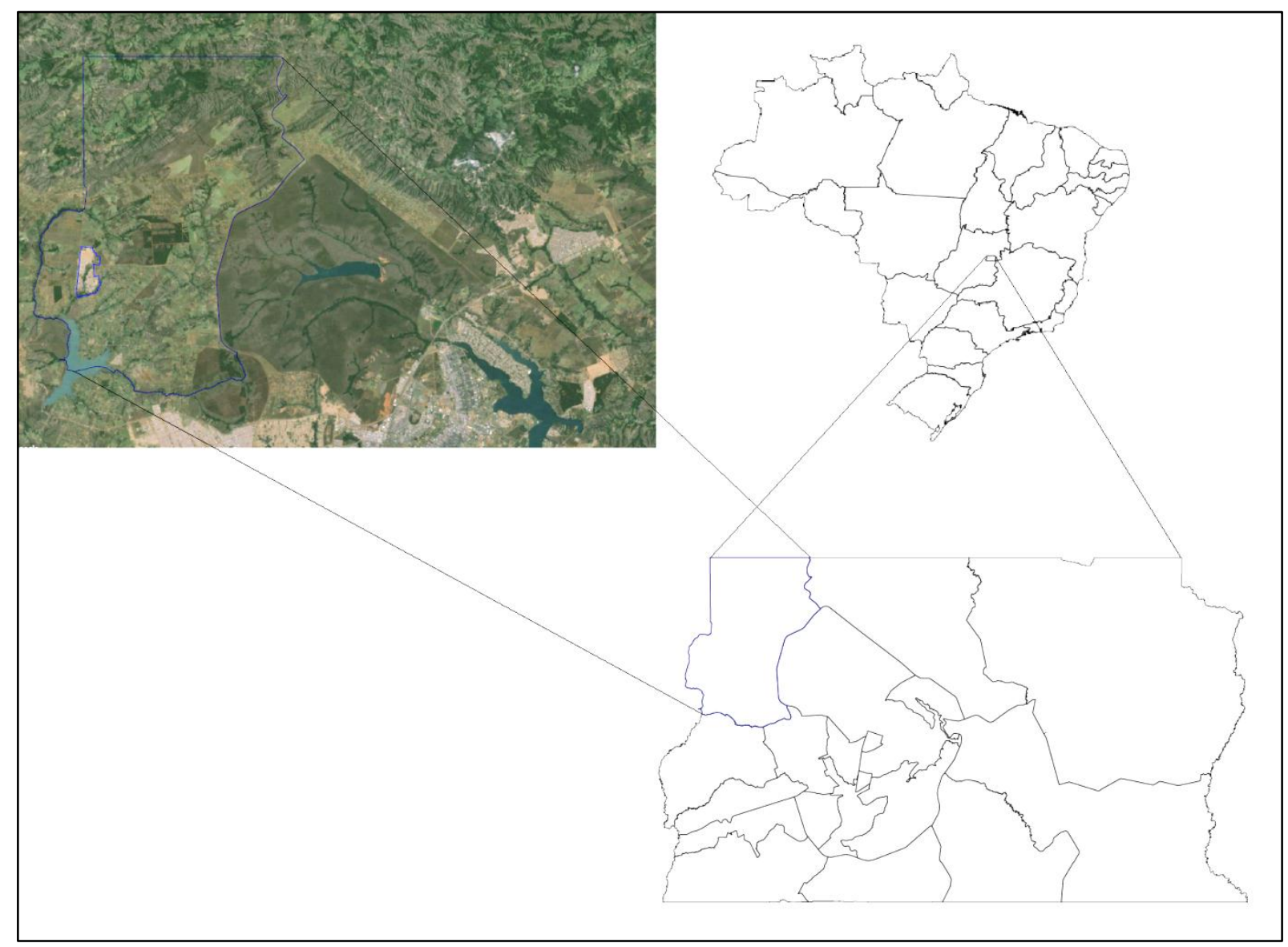

Imagem: Google Earth, 2016

Elaboração: Sophia da Costa Lacerda

A importância do rural em Brazlândia não se manifesta somente na abrangência de sua área, já que este espaço não é um vazio de pessoas, uma proporção considerável da população vive na zona rural. Dos 57.542 habitantes de Brazlândia, 26\% reside no perímetro rural e 74\% mora dentro dos limites do perímetro urbano. É importante ressaltar que está proporção de pessoas no rural é bem maior que a média nacional que é de cerca de $16 \%$ (IBGE, Censo 2010).

A relevância do rural em Brazlândia remonta as suas origens que se deu devido à migração de famílias que tinham o intuito de usar as terras da região para o desenvolvimento de uma agricultura extensiva. A vila que posteriormente daria origem a Brazlândia foi formada a partir da migração de quatro famílias à Chapada do Vão dos Angicos a partir do final do século XIX. As famílias Braz, Abreu de Lima e Rodrigues do Prado eram oriundas de Minas Gerias, já a última família a chegar, por volta de 1910, ao povoado que começava a se constituir, foi a Cardoso de Oliveira vinda da cidade de Posse em Goiás. As famílias se 
fixaram na região com o intuito de desenvolver atividades agropecuárias que possuíam fortes ligações com o município goiano de Santa Luzia, atual município de Luziânia.

Em 15 de abril de 1932 Brazlândia foi elevada à categoria de distrito de Santa Luzia e recebeu o nome como homenagem a família mais numerosa e influente, a família Braz. O decreto de criação do distrito previa a estruturação de um centro urbano no decorrer dos cinco anos seguintes, algo que não se concretizou, reforçando a característica de povoado (VASCONCELOS, 1988).

Neste sentido, até meados do século XX Brazlândia não era impactada diretamente pelos processos que eram externos ao seu contexto territorial, as famílias que ali residiam permaneciam desenvolvendo atividades que envolviam a agropecuária extensiva ou a agricultura de subsistência, sendo que as atividades econômicas eram pautadas pelas relações estabelecidas com os municípios vizinhos. Todavia, a transferência da Capital Federal para o planalto central acarretou mudanças significativas em Brazlândia que contava até então com menos de mil moradores. A partir de 1958 foram desapropriadas terras das fazendas da região, mais de mil alqueires, para criar diversos loteamentos que receberiam famílias transferidas de invasões e novos migrantes que residiriam tanto na zona rural quanto urbana. Um dos primeiros loteamentos criados em Brazlândia teve o propósito de abrigar famílias transferidas de áreas com conflitos de moradia. Este loteamento foi constituído através da expansão do setor tradicional de Brazlândia e era composto por cerca de 2.000 casas destinadas às famílias oriundas da invasão Vietcong, situada entre Taguatinga e o Montaria Country Club (VASCONCELOS, 1988).

Em 10 de dezembro de 1964, por meio da Lei $n^{\circ}$ 4.545, Brazlândia se tornou a Região Administrativa IV. Os limites da RA IV passaram a ser ao norte o município de Padre Bernardo, pertencente ao estado de Goiás, ao sul RA IX (Ceilândia) e RA III (Taguatinga), ao leste a RA I (Brasília) e a RA XXVI (Sobradinho I) e a oeste, novamente, o município de Padre Bernardo e Águas Lindas, ambos pertencentes ao estado de Goiás.

Após a institucionalização de Brazlândia como uma das regiões administrativas da capital, muitas famílias passaram a se estabelecer nesta região. A migração dessas famílias ocorria devido a três principais fatores.

O primeiro deles se relacionava com a intencionalidade política do ordenamento espacial rural no contexto de criação de Brasília. Como já discutimos, nos primeiros anos de criação da nova capital as políticas de ordenamento territorial tinham o propósito de estimular o estabelecimento de uma agricultura de abastecimento na zona rural. Neste contexto, foi 
estimulada a migração de famílias tradicionais de agricultores, vindas de outras regiões do país, com o propósito de ocupar as áreas rurais de Brazlânida e desenvolver atividades agrícolas.

Sobre este momento Rebelo Junior (1992) destaca que o processo inicial de consolidação dos núcleos rurais no Distrito Federal teve como responsável o Estado que coordenaria o sistema de produção, sendo assim "toda a concepção de criação do espaço rural do Distrito Federal foi dirigida pelo Estado" (REBELO JUNIOR, 1992, p.50). Em um primeiro momento, foi priorizada a agricultura de abastecimento, que deveria ter a lógica de produção familiar, mas com o seguinte diferencial: “o agricultor faria uso da terra pública, para fins públicos, sob a forma privada (...) o agricultor produziria visando o valor de troca, mas o valor de uso estaria explicitado pela política estatal de alimentação" (REBELO JUNIOR, 1992, p.51).

Dadas as necessidades das polícias agrícolas daquela época, o Núcleo Rural de Alexandre Gusmão foi um dos primeiros a ser instituído em Brazlândia, sendo criado em 1962, através do Decreto $\mathrm{n}^{\circ} 51.517$, porém a colonização deste núcleo rural se iniciou em 1967 com a chegada das famílias Uchida e Sugimoto, de origem japonesa, Sandeiro, de origem espanhola, Vaz da Silva e Cerqueira famílias oriundas de Minas Gerais e Pernambuco, respectivamente. As principais atividades produtivas desenvolvidas por estas famílias eram cultivo de hortaliças, a criação de peixes, o cultivo de frutas e a criação de gado, suínos e aves. Tais atividades agrícolas supriam as necessidades de consumo das próprias famílias e abasteciam os mercados de Brasília (EMATER, 2011).

A escassez de áreas habitacionais no plano piloto foi outro fator que impulsionou o deslocamento de famílias para Brazlândia. O ordenamento territorial urbano de Brasília não respondeu adequadamente ao contingente populacional que passou a ocupar a nova capital. Por isso, famílias que residiam em alguns assentamentos irregulares nas regiões do Guará, Núcleo Bandeirante e Taguatinga foram deslocadas para Brazlândia.

É possível identificar terceiro fator que também colaborou para migração de famílias para Brazlândia, também relacionado com a necessidade de garantir o abastecimento de alimentos para região. À medida que os aglomerados urbanos do Distrito Federal se expandiam foi aumentando a pressão sobre as áreas inicialmente destinadas para compor o cinturão verde. As famílias de agricultores foram paulatinamente perdendo a suas áreas produtivas para implantação de lotes residenciais e comerciais. Uma parte dessas famílias, principalmente aquelas que moravam nos núcleos rurais localizados em Vicente Pires e 
Taguatinga, passaram a residir em Brazlândia mantendo suas atividades produtivas ligadas à agricultura.

Um fluxo migratório mais recente em Brazlândia, no que se refere à ocupação do espaço rural, é decorrente das conquistas da luta pela terra de movimentos do campo a partir dos anos 1990. Devido a pressão política dos movimentos sociais de luta pela terra, atualmente Brazlândia possui seis assentamentos de Reforma Agrária, sendo eles: Gabriela Monteiro, Graziela Alves, Doroty Stein, Betinho, Canaã e Maranata. Estes assentamentos abrigam famílias provenientes de diversas regiões do país. Estas famílias, que passaram ser beneficiadas pelas políticas de reforma agrária, são famílias de agricultores que por meio do direito adquirido da terra puderam retomar suas atividades produtivas.

A ocupação de Brazlândia foi influenciada em grande medida pela transferência da capital para o planalto central. O grande número de pessoas que chegava a região da nova capital e as políticas de ordenamento territorial da área de abrangência do Distrito Federal impactaram diretamente a configuração territorial de Brazlândia, que até então era penas um distrito do atual município de Luziânia. Dessa forma, cerca de $44 \%$ da população total desta Região Administrativa é composta por imigrantes que chegaram após 1960 (CODEPLAN, 2015c)

Quando olhamos especificamente para o contexto rural desta região administrativa, percebemos que o rural é composto por dois grupos de famílias de agricultores. O primeiro compreende as famílias que tradicionalmente exerciam atividades agrícolas em seus locais de origem e por um incentivo de Estado passaram a produzir nos núcleos rurais de Brazlândia, aplicando assim as suas técnicas de cultivo. O segundo grupo se constitui por famílias que devido a processos diversos perderam o direito de ter acesso a terra e retomaram o desenvolvimento de sua agricultura em um novo cenário.

Sendo assim, a identidade do rural de Brazlândia é pautada pela diversidade não só no que se refere à existência de famílias vindas de diversas regiões ou até mesmo de outros países, como é o caso da comunidade japonesa, mas também no que se refere ao arcabouço técnico que orienta o cultivo da terra.

A estrutura produtiva, de uma forma geral, se mantem como incialmente concebida pelo poder público, é composta por pequenas propriedades que se dedicam a produção de hortaliças, frutas e pequenos animais. Todavia, as famílias desenvolvem a agricultura em propriedades com diferentes realidades. Há casos em que a atividade produtiva tem baixa inserção no mercado e a propriedade possui deficiência de infraestrutura, mas também existe 
empreendimentos familiares com elevada produtividade e com pequenas agroindústrias, de forma que a renda familiar em sua totalidade provém da agricultura.

O cultivo do morango tem um especial destaque dentro da produção agrícola de Brazlândia. A produção de morango é tão relevante que motivou a criação da Festa do Morango de Brazlândia, que ocorre anualmente desde 1996 e já é bem conhecida na região do Distrito Federal. O núcleo rural de Alexandre Gusmão é responsável por sediar a Festa do Morango, sendo que a festa é organizada pela ARCAG - Associação Recreativa e Cultural de Alexandre de Gusmão. Nos últimos anos a produção de goiaba também tem ganhado relevância dentro da produção agrícola de Brazlândia, o que motivou organização da $1^{\circ}$ Festa da Goiaba em março deste ano, aos moldes da Festa do Morango, tendo como principal objetivo fortalecer os canais de comercialização da goiaba.

É muito comum encontramos a figura de meeiros nas propriedades rurais de Brazlândia. Estes meeiros apesar de não terem o direito de propriedade da terra desenvolvem suas atividades produtivas em parceria com os titulares da terra. É importante ressaltar, que no caso de Brazlândia, não se nota uma relação entre o meeiro e o titular da terra pautada pela exploração. Em muitos casos são famílias amigas que estabelecem laços de compadrio. Contudo, os meeiros por não serem proprietários da terra não conseguem obter uma renda através do cultivo proporcional a dos donos da terra, assim aqueles ficam em uma situação econômica inferior a estes.

A regularização fundiária das terras apresenta diversos problemas que têm suas origens na forma como foi organizada a destinação das áreas para o ordenamento territorial do que viria a ser a Região Administrativa de Brazlândia, nos anos iniciais da consolidação do Distrito Federal. O processo de concessão de terras às famílias que iriam ocupar os primeiros núcleos rurais de Brazlândia foi feito por meio de contratos de arredamento que deveriam ter um tempo determinado.

Na década de 1970 as terras que correspondiam aos núcleos rurais foram devolvidas à União, sendo que no contexto de Brazlândia, o Incra seria responsável por dar sequência ao processo de regularização, conferindo o direito de propriedade definitivo para as famílias que já ocupavam aquelas terras. Contudo, este processo até os dias de hoje não foi finalizado e carece de uma clareza das instituições governamentais sobre a regularização e utilização das terras. Algumas áreas que antes foram destinadas ao cultivo de alimentos com o passar dos anos foram consideradas de proteção ambiental, e o caso inverso também ocorreu. Um exemplo é a Área de Proteção Ambiental da Bacia do Rio Descoberto, com a sua criação em 
1983 passou a ser restrito, em sua área de abrangência, o desenvolvimento de certas atividades econômicas, como criação comercial de aves, suínos e abatedouros. Outro exemplo são as áreas conhecidas como Reserva D e A, tais áreas nos anos iniciais do ordenamento territorial de Brazlândia foram pensadas para serem áreas de conservação ambiental. Contudo, com o passar dos anos o próprio poder público promoveu o loteamento dessas áreas com o propósito de abrigar empreendimentos agrícolas, e hoje também encontramos loteamentos residenciais.

A lentidão do Estado em regularizar diversas áreas em Brazlândia tem provocado uma falta de clareza institucional sobre o direito de uso da terra. Além disso, tem havido um aumento sobre a especulação imobiliária o que pode ameaçar a existência de áreas destinadas à produção em médio e longo prazo.

A política de proteção ambiental que se fortaleceu nos finais dos anos 1980 também tem um impacto sobre a utilização das áreas rurais de Brazlândia, gerando conflitos com as famílias que anteriormente já desenvolviam atividades produtivas nas localidades que passaram a ser de proteção ambiental.

Através da análise da constituição do território rural de Brazlândia conseguimos perceber que a região sofreu grande influência de processos impulsionados pelo evento da transferência da Capital para o Planalto Central. A relevância da produção de alimentos que hoje encontramos em Brazlândia e a existência de uma estrutura produtiva de base familiar encontram seus motivos nas intencionalidades do Estado sobre o espaço rural de Brazlândia. Todavia, os incentivos concebidos pelas instituições governamentais para a vinda de famílias para região em certas situações não foram coerentes, implicando em confusões quando a titularidade das terras.

É preciso ressaltar que embora o Estado tenha criados mecanismos para consolidar a agricultura de base familiar em Brazlândia, interesses externos tem ameaçado a sustentabilidade deste modelo. A agricultura em larga escala concorre com agricultura de base familiar que não consegue produzir a um preço de mercado tão reduzido, por isso os agricultores abandonam o cultivo de determinados gêneros e ficam vulneráveis às oscilações de mercado.

\subsection{A incorporação de práticas agrícolas sustentável em Brazlândia e a influência da Emater-DF}

As práticas agrícolas sustentáveis têm cada vez mais ganhado relevância dentro do cenário agrícola do Brasil. Já discutimos nos capítulos anteriores que as consequências da 
agricultura convencional sobre os recursos naturais e também sobre as formas de vida do homem, contribuíram para que a agroecologia emergisse como uma alternativa para propiciar os processos de desenvolvimento sustentáveis.

Ainda no âmbito da importância das modificações do modelo de produção agrícola ainda hegemônico em nossos dias, encontramos a agricultura familiar como um importante instrumento capaz de resgatar a função ambiental dos territórios rurais.

Tendo em vista o contexto do território rural de Brazlândia procuramos entender como a Emater-DF tem influenciado sobre a modificação das técnicas de cultivo empregas pelos agricultores da região. Considerando os objetivos desta pesquisa e a metodologia utilizada, descritos na introdução desta dissertação, optamos por realizar entrevistas (anexo IV) com os agricultores que participaram do Projeto Sustentabilidade. Esta seção deste capítulo analisa as entrevistas realizadas de modo a evidenciar os elementos que permitem ter uma maior clareza sobre o contexto territorial vivenciado pelos agricultores e a influência da Emater-DF sobre seus modos de cultivo.

Ao todo foram entrevistados 8 agricultores que desenvolvem suas atividades na comunidade Chapadinha de Brazlândia (Figura 3) e recebem assessoria do escritório Alexandre Gusmão da Emater-DF. O principal critério para a seleção dos agricultores foi ter participado do Projeto Sustentabilidade. Neste sentido, o perfil dos agricultores entrevistados se assemelha ao perfil dos agricultores atendidos pelo Projeto Sustentabilidade em Brazlândia. Sendo assim, possuem uma renda média anual de 80 mil reais e a estrutura produtiva não é precária o que permite a garantia da renda familiar por meio das atividades agrícolas.

A composição da amostra seguiu o método bola de neve, onde os próprios entrevistados indicam os novos indivíduos que serão submetidos às entrevistas. A primeira família seleciona foi decorrente de uma indicação do próprio escritório de Alexandre Gusmão, porém as demais famílias entrevistadas sempre foram contactadas a partir da indicação de uma família anteriormente entrevista. Neste sentido a amostra foi intencional, não sendo inadequada ao caráter da pesquisa que é qualitativo e tem o propósito de explicar uma realidade específica, sem, contudo, pretender fazer extrapolações para outros contextos semelhantes. 


\section{Figura 3 - Localização da Chapadinha - Brazlândia}

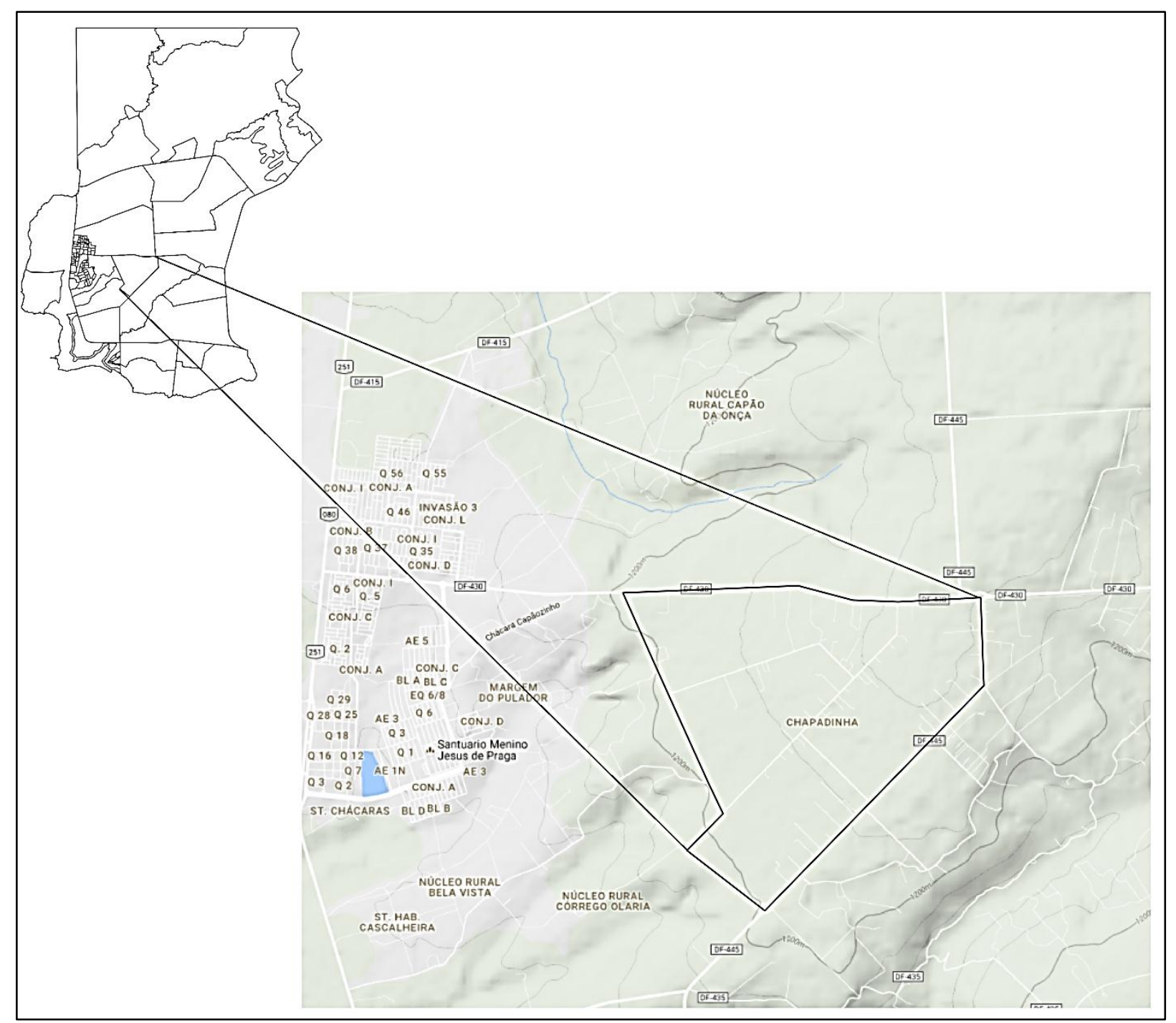

Imagem: Google Physical, 2016

Elaboração: Sophia da Costa Lacerda

As entrevistas seguiram um roteiro semiestruturado (anexo III), além disso, algumas questões, conforme o decorrer das entrevistas, puderam ser adaptadas com o propósito de proporcionar um melhor diálogo entre o entrevistador e o entrevistado. Neste sentido, foi possível captar as impressões dos entrevistados sobre a Emater-DF e práticas agrícolas sustentáveis, além de captar outros elementos relevantes para questão que não foram 
anteriormente previstos no processo de elaboração dos roteiros. Com o intuito de facilitar as análises posteriores, foi elaborada uma ficha para cada uma das entrevistas que continha os dados gerais de identificação das famílias e as transcrições dos áudios correspondentes à aplicação dos questionários.

A elaboração das questões seguiu quatro dimensões temáticas que tiveram o intuito de promover um maior conhecimento sobre a realidade dos agricultores no que se refere o escopo desta pesquisa. Neste sentido, foram definidas as seguintes dimensões temáticas: história de vida e estrutura produtiva das famílias, compreensão das famílias sobre o impacto das suas atividades sobre o meio ambiente, relação das famílias com a Emater-DF e percepção sobre as vantagens e desvantagens de produções agrícolas mais sustentáveis.

As entrevistas foram realizadas entre julho e agosto de 2016 e ocorreram em sua maioria, com a exceção de um caso, nas propriedades agrícolas das famílias. Em nenhuma das entrevistas houve a presença de técnicos da Emater-DF, isto possibilitou que os agricultores declarassem as suas impressões em relação a empresa sem constrangimentos. Na seção seguinte analisaremos as entrevistas a partir de 4 dimensões temáticas presentes nos roteiros de entrevista. Logo abaixo se encontra uma tabela de correspondência entre as questões as dimensões analisadas.

\section{Quadro 6 - Correspondência entre as Dimensões Analisadas e as Questões do Roteiro de Entrevista aplicado aos agricultores da Chapadinha - Brazlândia}

\begin{tabular}{|l|l|}
\hline \multicolumn{1}{|c|}{ Dimensão de Análise } & \multicolumn{1}{|c|}{ Questão do roteiro de entrevista } \\
\hline $\begin{array}{l}\text { História de vida e estrutura } \\
\text { produtiva das famílias }\end{array}$ & $\begin{array}{l}\text { Porque você se tornou agricultor? } \\
\text { O que levou você e a sua família a escolher Brazlândia } \\
\text { para morar e desenvolver as suas atividades produtivas? } \\
3 . \quad \text { Você se imagina exercendo outra profissão? } \\
4 . \quad \text { A renda da sua família depende da produção da sua } \\
\text { propriedade? Há outras atividades não agrícolas ou benefícios } \\
\text { sociais que auxiliam na complementação da renda? Se sim, } \\
\text { quais seriam? }\end{array}$ \\
$\begin{array}{l}\text { Compreensão das famílias } \\
\text { sobre o impacto das suas } \\
\text { atividades sobre o meio } \\
\text { ambiente }\end{array}$ & $\begin{array}{l}\text { 5. Você acredita que as suas atividades agrícolas } \\
\text { interferem na conservação dos recursos naturais aqui de } \\
\text { Brazlândia? Se sim, de que forma? } \\
9 . \\
\text { Participar do projeto sustentabilidade lhe fez pensar } \\
\text { um pouco mais sobre os cuidados com o meio ambiente? }\end{array}$ \\
\hline Relação das famílias com a & 6. \\
\hline
\end{tabular}




\begin{tabular}{|l|l|}
\hline Emater-DF & $\begin{array}{l}\text { DF? De que maneira a empresa tem lhe apoiado? Quais } \\
\text { atividades promovidas pela empresa você e sua família já } \\
\text { participaram? } \\
7 . \quad \text { As atividades desenvolvidas pela empresa sobre } \\
\text { práticas agrícolas sustentáveis têm influenciado a sua visão } \\
\text { sobre o cultivo de alimentos aqui em sua propriedade? } \\
8 . \quad \text { Quais técnicas você passou a utilizar em sua } \\
\text { propriedade após participar do Projeto Sustentabilidade? } \\
9 . \quad \text { Participar do projeto sustentabilidade lhe fez pensar } \\
\text { umpouco mais sobre os cuidados com o meio ambiente? }\end{array}$ \\
\hline $\begin{array}{l}\text { Vantagens e desvantagens de } \\
\text { produções agrícolas mais } \\
\text { sustentáveis }\end{array}$ & $\begin{array}{l}10 . \quad \text { Você acredita que práticas agrícolas mais sustentáveis } \\
\text { podem trazer um retorno financeiro equivalente aos das } \\
\text { práticas agrícolas convencionais? } \\
11 . \quad \text { Qual a sua compreensão sobre a agroecologia? } \\
12 . \quad \text { Você desejaria ter um modelo produtivo mais } \\
\text { sustentável, no qual não necessitaria de insumos externos a sua } \\
\text { propriedade? Se sim, quais seriam as dificuldades e facilidades } \\
\text { enfrentadas na mudança de seu modelo produtivo? Você } \\
\text { acredita que a Emater-DF poderia ajudar neste processo? }\end{array}$ \\
\hline
\end{tabular}

\subsubsection{História de vida e estrutura produtiva das famílias}

As famílias que moram na comunidade da Chapadinha desenvolvem as atividades produtivas em pequenas propriedades que possuem uma área média de 5 hectares. Os agricultores se dedicam a produção de hortaliças, com especial destaque para o morango.

Em uma mesma propriedade comumente vive mais de uma família. Nesta situação de ocupação do imóvel rural, as famílias podem compartilhar laços de parentesco, relações de parceria de produção ou relações de subordinação de trabalho (patrão e empregado). As propriedades possuem uma estrutura produtiva capaz de garantir a renda das famílias sem que haja necessidades de complementações com atividades não agrícolas. São os próprios membros das famílias que empregam a força de trabalho na produção, podendo contar com o auxílio de alguns colaboradores. Nesse sentido, encontramos um contexto típico de agricultura familiar.

As propriedades rurais da Chapadinha ainda não estão totalmente regularizadas. A maioria das famílias possuía título de posse da terra e estão aguardando a finalização da regularização que deve ser feita pelo Incra. Apenas uma família entrevistada desenvolve suas atividades em uma propriedade arrendada. É importante ressaltar que mesmo que estas famílias não possuam título de escritura da terra, a posse já lhes garante o direito sobre a terra e com isso possuem garantias para desenvolver a produção e, além disso, podem acessar as 
políticas de apoio à agricultura familiar, tais como: programas de crédito, programas de compras governamentais e serviços de Assistência Técnica e Extensão Rural.

As famílias entrevistas não possuem problemas de inserção em mercados de venda. Elas comercializam os produtos no Ceasa do Distrito Federal, em feiras do produtor em Ceilândia e Taguatinga e em mercados da região. As famílias também participam de programas de compras governamentais.

Todas as famílias entrevistadas eram tradicionalmente de agricultores, por gerações se dedicaram e ganharam experiência com o cultivo da terra. Os agricultores estão satisfeitos com a vida que levam, apesar de alguns considerarem difícil em certos momentos, principalmente quando há oscilações nos preços de mercado, porém não se imaginam exercendo outras atividades. Os filhos de alguns agricultores, após se formarem no ensino médio e em cursos de graduação, têm decidido permanecer na produção, porque consideram vantajosa a renda auferida. Além disso, os agricultores consideram que no meio rural há a possibilidade de se ter uma melhor qualidade de vida, já que o contato com a natureza confere benefícios à saúde e descanso, algo que não é possível de ser encontrado nos centros urbanos. Contudo, os assaltos com casos de violência aumentaram nos últimos anos na região, fazendo com que alguns agricultores se sintam inseguros em suas propriedades.

Outro importante fator que devemos ressaltar quanto ao contexto rural da Chapadinha, é o acesso a serviços públicos que tem sido favorecido pela proximidade da comunidade em relação ao centro urbano de Brazlânida (cerca de $8 \mathrm{~km}$ ). A comunidade conta com uma escola pública de nível fundamental (Escola Classe Chapadinha), há serviços de coleta de lixo e iluminação pública nas vias de acesso, que apesar de não serem todas asfaltadas, possuem boas condições de tráfego. Todavia a água das propriedades é retirada de poços.

Sendo assim, nas conversas com as famílias, encontramos agricultores que estão satisfeitos com a vida que levam e se identificam profundamente com atividade da agricultura familiar. Como podemos perceber através dos seguintes relatos extraídos das entrevistas:

"Não saio daqui mais nunca (...) Eu gosto muito de mexer com terra. Eu gosto de mexer com a natureza” (entrevista $\left.\mathrm{n}^{\circ} 2\right)$

"A agricultura não é uma profissão, você tem que gostar. Você faz porque você gosta. Lavrar a terra não é fácil, então você faz porque gosta. (...) o difícil da agricultura hoje é quando você trabalha de meeiro e porcenteiro. Mas quando você tem uma propriedade, ai não, facilita você mesmo pode fazer o seu salário com isso a gente vai acomodando". "Por mais que é dificil, a zona rural hoje está muito moderna. Nós aqui... nós temos todo o benefício que tem nas grandes cidades, a gente tem aqui na roça. Tem telefone, tem carro, tem internet, tem wi-fi, tem tudo, água, sanitário, coleta 
de lixo, iluminação pública. Tendo isso a agente até acomoda um pouco e vai ficando..." (entrevista $\left.n^{\circ} 6\right)$

As famílias entrevistadas são originárias de diversos estados do Brasil (São Paulo, Goiás, Pernambuco e Pará) e a mudança para Brazlândia representou para elas melhorias na qualidade de vida. A migração dessas famílias esteve atrelada ao padrão de desenvolvimento projetado sobre o território rural desta região nos anos seguintes a transferência da capital para o planalto central.

Como discorrermos anteriormente, o espaço rural de Brazlândia foi concebido pelas políticas de desenvolvimento rural da década de 1970 como um espaço que deveria abrigar pequenos produtores dedicados ao cultivo de alimentos que abasteceriam Brasília. Neste sentido, encontramos famílias de agricultores que chegaram à região nas décadas de 1970, 1980 e 1990 todas com os mesmos objetivos de explorar a produção de hortaliças, já que perceberam que a região havia se constituía como um polo produtivo que beneficiava os agricultores que se dedicavam a este tipo de produção. Na maioria dos casos, as famílias mudaram para Brazlândia devido à indicação de parentes ou conhecidos que já haviam se estabelecido na região e obtido sucesso com o desenvolvimento de suas atividades produtivas.

É importante ressaltar que se estabelecer em Brazlândia para muitas famílias representou uma mudança sobre a atividade produtiva que se dedicavam. Anteriormente, em seus locais de origem, elas se dedicavam a diferentes atividades agrícolas, tais como exploração de gado, produção de grãos, cultivo de algodão e exploração de madeira. Todavia se dedicar a outro tipo de atividade não representou grandes barreiras aos agricultores. Alguns consideraram que além das vantagens econômicas de trabalhar com hortaliças, eles também se beneficiaram com o trabalho que passou a demandar um menor esforço físico.

A maioria das famílias entrevistadas, com exceção de dois casos, quando chegaram em Brazlândia desenvolviam as suas atividades como meeiros e só depois de alguns anos conseguiram juntar economias para adquirir a própria terra. Após possuírem a própria terra perceberam melhoras nas condições de renda.

Logo, notamos que as famílias da comunidade Chapadinha chegaram a Brazlândia para fortalecer o modelo de ocupação espacial pensado pelos governos daquela época para a região. Sendo assim, não é de se admirar que apesar das famílias terem origens diversas e experiências em diferentes ramos da agricultura elas se adaptaram sem grandes dificuldades ao contexto produtivo agrícola de Brazlândia. 


\subsubsection{Compreensão das famílias sobre o impacto das suas atividades sobre o meio ambiente}

Os agricultores da comunidade de Chapadinha, com a exceção de um produtor orgânico, também entrevistado, empregam em sua produção, de forma preponderante, técnicas da agricultura convencional, ou seja, dependem de insumos químicos para o cultivo de alimentos. Todavia estes agricultores não se mostraram satisfeitos com esta situação, em muitos casos demostraram o desejo de modificarem os seus sistemas produtivos, porque consideram que estão impactando negativamente os recursos naturais. Porém apresentaram diversas dificuldades relacionadas com uma possível modificação em seus sistemas produtivas, as quais serão comentadas a seguir. É importante ressaltar que em boa parte das propriedades os agricultores têm adotado insumos orgânicos em seus respectivos agroecossistemas.

Dentre os 8 agricultores entrevistados, apenas três agricultores consideraram que não prejudicam o meio ambiente com o desenvolvimento de suas atividades produtivas; um deles porque é um produtor orgânico, já bem conhecido na região, e os outros dois porque apesar de usarem agrotóxicos na propriedade, seguem as orientações devidas sobre aplicações e descarte de embalagens. Neste sentido declarou o entrevistado 8: "tem que cuidar direito (da natureza) não deixar nada que dá poluição. Essas coisas tem que evitar, mas a gente recolhe tudo que é embalagem de veneno, qualquer coisa que pode prejudicar a natureza”. Este mesmo entrevistado acredita que não prejudica tanto o meio ambiente pelo fato de sua propriedade não estar próxima de cursos de água.

O restante dos agricultores entrevistados percebe que impactam negativamente o meio ambiente porque fazem uso de agrotóxicos e de técnicas do modelo de agricultura convencional. Dentre os impactos que citados pelos agricultores durante as entrevistas estão: degradação do solo, perda da biodiversidade, contaminação do solo e da água e consumo não consciente dos recursos naturais, como a água. Vale ressaltar que o elemento mais presente nas falas dos agricultores no que se refere aos prejuízos gerados pelo uso dos agrotóxicos, esteve o risco de intoxicação e desenvolvimento de doenças.

Os agricultores acreditam que o modelo de produção convencional que têm adotado tem feito com que a terra se torne "cansada", remetendo a perda da capacidade produtiva devido à perda dos nutrientes do solo.

"Como aqui tem muitos anos que a gente planta, o solo está precisando descansar" (entrevista $n^{\circ}$ ) 
"Agora a gente tá mudando, a gente vai plantar mais agora é fruta, porque a nossa terra está muito cansada já para hortaliça. Estamos começando a mudar, vamos plantar goiaba. Até o pessoal da Emater falou: essa terra ficando cansada, o melhor e plantar fruta" (entrevista $\left.n^{\circ} 1\right)$

"A gente vai plantando nessa terra, essa terra vai ficando velha. Ai ela vai criando mais coisa na terra que prejudica a planta. Não produz igual produzia aqui há muitos anos atrás" (entrevista $\left.n^{\circ} 8\right)$

Os agricultores entrevistados percebem que o agrotóxico tem sido o principal fator que faz com que os suas técnicas de cultivo prejudiquem os recursos naturais e gerem riscos a saúde deles e a dos consumidores. É interessante destacar que tais agricultores se sentem incomodados com esta situação e prefeririam não ter que fazer uso desses insumos. A seguir são destacados os principais trechos das falas que nos auxiliam a entender a percepção que estes agricultores possuem em relação ao uso de agrotóxicos.

"Em termos de produtos e defensivos acho (que minhas atividades agrícolas) prejudica" (entrevista $n^{\circ} 2$ )

"Quem mexe com agrotóxico não deixa de não ter impacto no meio ambiente. A gente se preocupa muito com a questão do meio ambiente, mas é complicado porque a gente acaba fazendo coisas que não devia com o meio ambiente" (entrevista $n^{\circ} 5$ )

"Um dos maiores problemas que temos aí na agricultura hoje, não só de Brasília, mas da nossa região também, do Brasil, é o uso inadequado deles (agrotóxicos)" (entrevista $\left.n^{\circ} 4\right)$

"O agrotóxico é um dos inimigos da gente. A gente aprende muito que o agrotóxico é um dos inimigos da gente e até para o consumidor. Você sabe, o câncer ele é provocado muito através do agrotóxico. Eu vejo muito agricultor as vezes que ele não tem a consciência dele, tão entendeu? (...) Ele está colhendo um morango hoje, termina de colher aqui e ele já vem com aquele veneno forte e com três dias depois ele sabe que vai ser obrigado a colher, e ele tá aplicando aquele mesmo produto" (entrevista $n^{\circ} 7$ ).

"Eu mesmo que sou produtor, eu não como o tomate da minha roça. Eu sou consciente, trabalho com ele? Trabalho, porque é o meu meio de sobrevivência. (...) Não é justo, a minha consciência fica pesada com aquilo ali, eu não vou mentir para você (entrevista $n^{\circ} 7$ ).

"Eu já joguei muito veneno. Tem um veneno ai que se eu jogar eu passo mal, mesmo com todo o equipamento. Ele não é bom usar porque destrói o solo, mas às vezes a gente usa ele porque não tem outra solução, não tem outro meio não tem quem faça. Mas nossa! Eu me sinto péssima!" (entrevista nº $\left.{ }^{\circ}\right)$ 
Devido ao reconhecimento dos malefícios causados pelo uso do agrotóxico, os agricultores entrevistados enfatizaram a importância de seguir as recomendações técnicas sobre a aplicação dos agrotóxicos. Além disso, em muitos casos eles têm empregado produtos orgânicos no cultivo dos alimentos e são favoráveis a redução do uso de agrotóxicos em suas propriedades.

"Aqui já se usou muito mais produtos químicos prejudicando a natureza do que a gente uso hoje. A gente usa muito misturado, o produto químico com o produto orgânico. Eu por exemplo, só uso o produto químico quando o orgânico já não dá mais jeito, quando a praga já se manifestou demais " (entrevista $n^{\circ} 2$ )

"Meu pai acaba usando produtos químicos... porque tem que mudar a ideia, ele é uma pessoa que já teve uma ideia muito anterior e ai não tem como... ele tem que ver o resultado e só aceitou usar o que eu estou usando porque ele viu o resultado no que eu fiz (...) Mas para você plantar isso na cabeça de uma pessoa é difícil (...) e ai a gente tenta, mas sai muito mais caro. Mas a gente tenta também mais por causa da gente, porque você jogar um produto químico ele te prejudica, mas se você jogar um orgânico ele não te faz mal. Não faz mal para você, não faz mal para planta e não faz mal para quem vai comer a planta. Mas é uma coisa que tem que ser tralhada a longo prazo e buscar fazer as pessoas entenderem isso. Porque igual o meu pai, ele ainda fica com pé atrás" (entrevista $n^{\circ} 2$ )

Em uma das entrevistas, em especial, foi enfatizada a importância de o Estado atuar para que possa haver uma mudança sobre os modelos de cultivo dos agricultores familiares. Neste sentido, o entrevistado em questão reconheceu o Estado como um importante ator para garantir que os agricultores familiares possam produzir com práticas agrícolas mais sustentáveis.

"A gente é conhecedor de que o meio ambiente é prejudicado. Até por que falta o Estado, o Estado não é presente. Você pensa em um setor que não tem o Estado, é a agricultura familiar. Não é porque o governo coloca lá uma renda lá, um tipo de financiamento lá no banco, que ele tá presente, não é isso. O agricultor, principalmente o pequeno produtor, ele não tem a presença do Estado. Então, é mais ou menos assim tipo: você vai ou fica, ou faz ou deixa de fazer. Então, quem vive disso, mesmo sabendo que tem alguma coisa que prejudica o meio ambiente e até mesmo a saúde da gente, mas a gente não tendo o Estado presente, você acaba ficando vulnerável a essas coisas... A gente usa o recurso que tem, as fontes que seja" (entrevista $\left.n^{\circ} 6\right)$

\subsubsection{A relação das famílias com a Emater-DF}

Os agricultores entrevistados consideram que a atuação da Emater-DF tem correspondido às necessidades deles em relação aos serviços de Ater. Eles reconhecem que a Empresa-DF está disposta a auxiliar naquilo que for preciso, prestando atendimento de 
diversas formas com o intuito de atingir a integralidade das dimensões que envolvem o fortalecimento da agricultura familiar. Por isso, a empresa promove atividades que envolvem apoio ao acesso a programas governamentais, técnicas de gestão da propriedade, fomento ao associativismo, orientações para melhoria da estrutura produtiva e inserção em mercados.

"A gente está sempre tendo assistência deles. Qualquer coisa que a gente precise a gente vai e eles estão sempre prontos para atender para ajudar a gente. A gente tem uma assistência muito boa da Emater, boa mesmo (...) A gente não tem o que reclamar. Eles dão apoio para tudo" (entrevista $n^{\circ} 1$ )

“A empresa está muito presente para dar todo o auxílio possível” (entrevista $\left.n^{\circ} 4\right)$

"Sempre que a gente precisa, eles estão muito disposto a servir a gente. Em questão de projetos, algum receituário. Sempre que a gente necessita deles, eles estão disposto a servir" (entrevista $n^{\circ}$ )

"A Emater sempre tá me acompanhando quando eu sempre preciso" "Pra mim mesmo o pessoal da Emater é muito importante” (entrevista $n^{\circ} 7$ )

"Eles ensina muita coisa. Faz reunião, ai você participa da reunião, dá palestras, você aprende o que é preciso" (entrevista $n^{\circ} 8$ )

Durante as entrevistas foi possível perceber que os agricultores possuem um bom relacionamento com a Emater-DF. Eles já participaram de diversas atividades promovidas pela empresa pública, tais como: cursos, palestras, oficinas, visitas de campo, excursões para feiras agrícolas, etc. Todos os entrevistado não conseguiram enumerar a quantidade de atividades que participaram, sempre respondiam que já haviam participado de várias, ou seja, estar envolvido com ações da Emater-DF não é um evento esporádico em seus cotidianos.

Os agricultores pontuaram que as atividades abrangem um número grande de temáticas, o que demostra que o serviço de Ater prestado busca orientar o agricultor em diferentes aspectos. Dentre as temáticas estão: gestão financeira da propriedade, rotação de culturas, adubação orgânica, técnicas de quebra-vento, preservação de nascentes, recuperação de vegetação nativa, uso racional da água, elaboração de projetos produtivos, orientações para o acesso a programas governamentais, inserção no mercado, aplicação de agrotóxico e uso de equipamentos de proteção. Além disso, as excursões para outras propriedades, a fim de conhecer outros sistemas produtivos, foram consideradas pelos agricultores entrevistados como relevantes para conhecer práticas agrícolas mais sustentáveis e que são possíveis de serem aplicadas em seus contextos agrícolas. 
Atribui-se a atuação da empresa as melhorias na estrutura produtiva, aumento da produtividade e uma melhor inserção dos produtos no mercado. Neste sentido, a empresa tem sido de grande importância para o desenvolvimento das atividades produtivas desses agricultores.

É importante ressaltar que em todas as entrevistas a questão das orientações sobre o uso de agrotóxicos apareceu como sendo uma ênfase dada pela empresa. Ou seja, foi possível perceber que há uma grande preocupação por parte da instituição de conscientizar os agricultores sobre o uso adequado dos agrotóxicos e, quando possível, o uso de produtos orgânicos para substituí-los.

"A gente tem diminuído muito porque a Emater tem orientado muito a gente a usar menos agrotóxico. Ensinando também como usar produtos que traz menos danos. Ajudando a cuidar da produção de forma que ela seja mais sustentável." (entrevista $\left.n^{o} 6\right)$

Em relação à participação no Projeto Sustentabilidade, todos os entrevistados consideraram que foi de grande importância, tanto no aspecto de adquirir conhecimentos sobre novas técnicas agrícolas, quanto no desenvolvimento de uma visão diferenciada sobre o meio ambiente. Além disso, foi possível observar que há um entendimento sistêmico por parte dos agricultores no que se refere aos ciclos naturais.

"Abre a visão da gente. Toda vez a gente visa só lucro, mas vê que tem todo um processo que influencia da vida de muitas pessoas." (O nosso cultivo) "não interfere no cotidiano só na gente, mas também dos nossos vizinhos, nos que adquire os produtos que a gente produz" (entrevista $n^{\circ} 4$ )

"A gente começa a melhorar aquilo que a gente já sabe fazer, né? A gente se esforça mais um pouquinho para fazer melhor ainda, porque a gente viu que dá para melhorar" (entrevista $n^{\circ} 5$ )

"A gente passa ter outro pensamento, outro foco para trabalhar (...) Fez pensar mais no impacto. As vezes você não cuida bem do meio ambiente, o impacto que causa, o efeito para as nossas vidas mesmo. Mudou muita coisa, esse projeto foi muito bom" (entrevista $\left.n^{\circ} 1\right)$

"Eles tem incentivado mesmo os agricultores para mudar para o orgânico, justamente para preservação da nossa vida, do solo, de tudo" (entrevista $n^{\circ} 1$ )

"O cuidado com o meio ambiente é o cuidado com o ser humano também" (entrevista $\left.n^{o} 6\right)$ 
Apesar dos diversos aspectos pontuados, que nos levam a perceber que a empresa tem direcionado seus serviços de Ater para o fomento de práticas agrícolas mais sustentáveis, os agricultores que já estão há mais tempo na Chapadinha pontuaram sobre a mudança no perfil de atuação da Emater-DF em Brazlândia. Na última década a Emater-DF passou a ser mais presente e a disseminar conhecimentos sobre as práticas agrícolas sustentáveis. É importante ressaltar que a mudança no perfil de atuação da Emater-DF é decorrente do fortalecimento desta política a partir dos anos 2000, década na qual é implementada a Política Nacional de Ater que passa a dar uma especial ênfase à agroecologia.

"A Emater foi se estabelecer, foi dar uma assistência realmente legal aqui, foi nos últimos dez anos para cá. Aí, a Emater, ela é realmente presente. Mas antes era uma coisa muito distante, sabe?. Nos últimos dez anos tem sido bem legal" (entrevista $n^{o}$ 6)

Embora haja muitos aspectos positivos pontuados pelos agricultores, houve críticas em relação à organização dos atendimentos. Há poucos exensionistas para uma grande quantidade de agricultores, uma proporção aproximada de três extensionistas pra 400 agricultores. Além disso, fora do Projeto Sustentabilidade, o atendimento que é organizado somente a partir da demanda dos agricultores, prejudica o acompanhamento mais detido do desenvolvimento dos cultivos. Por isso, ocorre situações onde o técnico comparece a propriedade quando já há um grande desequilíbrio do agroecossistema e a produção está seriamente comprometida.

\subsubsection{Perspectiva dos agricultores entrevistados sobre a transição para modelos produtivos sustentáveis}

Ao iniciar as entrevistas foi possível perceber que os agricultores tinham muito pouco ou nenhum conhecimento sobre agroecologia. A maioria deles associam práticas mais sustentáveis à produção de alimentos orgânicos. Ou seja, a transição para modelos produtivos mais sustentáveis, no caso de Chapadinha em Brazlândia, passaria pela produção de alimentos orgânicos. A produção orgânica utiliza alguns princípios da agroecologia, tais como: redução da dependência de insumos comerciais, utilização de recursos renováveis, controle biológico de pragas e otimização no uso dos recursos naturais.

Os agricultores entrevistados percebem que a produção orgânica traz um melhor equilíbrio ecológico para os agroecossistemas. Dentre os benefícios apontados estiveram: melhoria na qualidade dos produtos, maior valor de mercado dos produtos, preservação dos 
recursos naturais, ausência de riscos para a saúde dos produtores e dos consumidores e sustentação da produção ao longo do tempo.

"Se a gente bagunçar o meio ambiente, a própria natureza pode se revoltar contra você. Bom é mesmo você preservar (...) A natureza agradece. Se você zela por ela, a natureza lhe dá em dobro. E se você vai só explorando ela, ela chega uma hora que ela vai dizer assim: 'não, eu não vou te dar'. Eu não vejo não para mim, mas para os meus filhos, para os meus netos, por isso se você não for preservando a natureza daqui a trinta, quarenta anos, que será de nós sem a natureza? (...)A natureza ela dá e ela toma, se você não souber preservar ela" (entrevista $n^{\circ} 7$ )

Em todos os casos foi possível perceber uma preferência pelas práticas agrícolas sustentáveis em relação às práticas convencionais. Em muitos casos houve um desejo real para mudança em seus sistemas produtivos. Como já apontamos, apesar destes agricultores utilizarem predominantemente técnicas convencionais, eles também têm usado insumos orgânicos na produção e feito tentativas para substituição dos produtos agroquímicos utilizados. Apesar de haver o desejo de mudança, há algumas dificuldades que são apontadas pelos agricultores para que de fato haja uma transição dos modelos produtivos.

A primeira dessas dificuldades, que teve uma grande ênfase nas falas, é o fato dos produtores da localidade terem, em sua maioria, um modelo produtivo convencional. As atividades produtivas de uma propriedade necessariamente afetarão as atividades produtivas das outras propriedades devido à pequena distância que as separam.

"Para ser sincero. Nesse lugar aqui que eu moro não tem como não. Porque meus vizinhos, né?.. tem muitos que mexem com químico e contamina” (entrevista $n^{\circ} 5$ )

"Não adianta eu começar aqui porque os produtores em volta são todos convencionais" (entrevista $n^{\circ}$ 2)

“As nossas propriedades são pequenas. Então nós depende muito dos nossos confrontantes para poder produzir orgânico. Aqui na nossa região é quase impossível produzir orgânico, porque as propriedades são muito perto, muito junto. Então não deixa de estar contaminando, passando de uma propriedade para outra, até porque os maquinários são os mesmos" (entrevista $\left.n^{\circ} 6\right)$

O cultivo desenvolvido durante muitos anos por meio do modelo produtivo convencional, também foi apontado como um dos motivos que dificultariam a transição. Pelo ponto de vista dos agricultores, o solo já teria sido desgastado e contaminado por produtos químicos. Por isso o processo de recomposição e descontaminação levaria muito tempo e implicaria em deixar de produzir algo que comprometeria a renda familiar. Para esta 
dificuldade, alguns agricultores entrevistado apontaram como solução a aquisição de novas propriedades que não tenham sofrido com o modelo produtivo convencional.

"Se eu começar uma propriedade nova com produtos orgânicos eu já tenho a própria natureza me ajudando. Quando você tem a natureza você não gasta tanto (...) Eé lógico em termos de valores, o produto orgânico é muito mais caro" (entrevista $n^{o} 2$ )

"Mudar para orgânico enquanto eu estiver aqui, eu acho que não consigo não. A não ser que a gente adquira outra propriedade bem mais longe, afastado. Assim a gente pensa, porque é bom para todos, é bom para todo mundo, para quem trabalha, para quem produz e para quem consome" (entrevista $n^{\circ} 6$ )

"Eu mudaria hoje o meu sistema de trabalho, eu ia para o orgânico, mas não tenho. Porque a propriedade para ser orgânica ela tem que vir do alicerce. Não é hoje que eи vou mudar o meu sistema de trabalho (...) Se eu fosse para fazer hoje, eu teria que pegar um terra nova, uma terra que nunca foi plantada" (entrevista $n^{\circ} 7$ )

Outra dificuldade apontada para uma possível transição seria o mercado de vendas de produtos orgânicos. Para alguns haveria dificuldades em relação a conquista de mercado. Alguns entrevistados acreditam que não há uma grande demanda por produtos orgânicos e por isso poderiam enfrentar dificuldades no que diz respeito ao escoamento da produção.

É importante ressaltar que em muitas falas os agricultores projetaram como cenário ideal para a agricultura brasileira aquele onde todos os agricultores passassem a ter sistemas produtivos mais sustentáveis. Neste sentido, eles percebem que poderia haver uma conjuntura favorável para manutenção em longo prazo de um modelo produtivo que trouxesse menos impactos negativos ao meio ambiente.

"Se pudesse, de modo geral, todos os agricultor, produtor rural, cada qual colocasse em seu lugar, se todo mundo passasse a produzir orgânico, seria uma grande maravilha em nosso país, nosso país inteiro. Isso ai que é importante: a gente sair fora desse tal de agrotóxico, ele acaba com a gente" (entrevista $n^{\circ} 7$ )

"Acho que todo o agricultor aqui do Brasil deveria pensar nisso" "Acho se todo mundo passasse ser orgânico, melhorava todo mundo, o custo de investimento poderia ser alto, mas o retorno seria melhor para todo mundo " (entrevista $\left.n^{\circ} 1\right)$

Após a descrição dos principais aspectos observados nas entrevistas sobre os modelos produtivos dos agricultores, a perspectiva deles em relação às práticas agrícolas mais sustentáveis e a relação existente com a Emate-DF, a seguir vamos analisar como o fomento às práticas agrícolas mais sustentáveis se relacionam com a transformação do território, no caso de Brazlândia. 


\subsection{A difusão da Agroecologia pela Emater-DF em Brazlândia e sua relação com a territorialidade}

A agroecologia ainda não foi incorporada de forma concreta em Brazlândia. Contudo, os princípios deste campo de conhecimento começam a ser observados em casos pontuais na Comunidade de Chapadinha, apontando para mudança em direção a um uso mais sustentável do território. $\mathrm{O}$ consenso entre os agricultores que os agrotóxicos não são insumos ideias para o cultivo de alimentos e a incorporação paulatina de técnicas de produção orgânica, denotam uma preocupação em relação aos recursos naturais e a saúde do ser humano.

O uso sustentável do território, de forma que a função ambiental seja valorizada, é um processo que não é simples. Como discutimos em capítulos anteriores, a própria noção de sustentabilidade depende muito dos atores que fazem uso dela. No contexto rural, identificamos que a agricultura familiar é um agente relevante para transformação dos modelos que temos hoje. É a agricultura familiar que reconhece a terra como seu meio de sobrevivência, e, sendo assim, os recursos naturais devem ser preservados, porque se assim não for seu modo de reprodução estará comprometido.

A agroecologia aparece nesse cenário como uma ciência que pode dar a tonalidade do desenvolvimento sustentável nos territórios rurais. É através da agroecologia que o sentido de equilíbrio ecológico e autonomia dos agroecossistemas são valorizados. Além disso, a agroecologia possibilita que os contextos territoriais não se submetam a projetos externos de imposição de modelos produtivos.

A agroecologia só se torna factível, se, no território, os atores incorporam, em suas relações sociais e com o meio natural, os princípios da agroecologia. Vimos com Raffestin, que o território depende da forma como os atores se relacionam com o intuito de ter os seus projetos concretizados. Por isso, no caso do desenvolvimento de práticas sustentáveis em um dado território, é essencial que haja uma confluência entre os projetos dos atores envolvidos. No caso da comunidade Chapadinha de Brazlândia, devemos destacar o papel de dois atores nesta questão, a agricultura familiar e a Emater-DF

A Emater-DF, como podemos identificar pelas entrevistas com os agricultores, possui um grande poder de influência sobre o território rural de Brazlândia. A Emater-DF é uma instituição que, além de possuir legitimidade política, possui um conhecimento técnico de grande interesse dos agricultores. Este conhecimento técnico é capaz de interferir sobre a forma de uso dos recursos naturais. Vale destacar que os limites de atuação desta instituição estão relacionados com a sua capacidade operacional, ou seja, os recursos humanos e 
financeiros aportados para execução de seus projetos. A disponibilidade de tais recursos depende da agenda política do Distrito Federal, no que tange a temática de políticas públicas para o rural.

O Programa Agroecologia possui pouca ênfase dentro das ações da instituição, dada a ausência de uma articulação concertada entre as ações propostas a fim de que seja possível o alcance das metas traçadas pela instituição. O Projeto Sustentabilidade trouxe importantes avanços na questão do desenvolvimento sustentável do território, todavia foi um projeto concebido pelo governo federal através do até então Ministério do Desenvolvimento Agrário. Para que a Emater-DF continue evoluindo, no sentido de fortalecer o uso sustentável do território, é necessário que projetos como o Sustentabilidade tenham uma atuação de longo prazo e sejam incorporados definitivamente pela instituição.

A agricultura familiar da comunidade de Chapadinha tem seu perfil de atuação moldado pelos padrões de desenvolvimento rural que foram preponderantes nas últimas décadas. A migração desses agricultores ocorreu em resposta aos incentivos governamentais para desenvolver no espaço rural de Brazlândia uma agricultura de abastecimento. Além disso, as técnicas empregadas na produção de alimentos acabaram por seguir o padrão da agricultura convencional. Neste sentido, a agricultura desenvolvida nas pequenas propriedades desta região depende em grande medida de insumos externos. Todavia, conseguimos observar que a agricultura familiar da comunidade de Chapadinha apresenta um potencial para modificar a forma como são utilizados os recursos naturais. Este potencial se encontra na própria insatisfação dos agricultores em relação ao modelo produtivo que utilizam. Como vimos, durante as entrevistas, as justificativas para a não modificação imediata dos modelos produtivos estavam atreladas a fatores conjunturais, sendo que na esfera pessoal os agricultores manifestaram desejos de mudança.

Os motivos para manifestação do desejo de mudança sem, contudo, apresentar uma materialidade para tanto, pode ser analisado a partir do território abrangido pela comunidade da Chapadinha. Bonnemaison (2012) aponta que o território é ao mesmo tempo um espaço social (produzido) e um espaço cultural (vivenciando), possuindo uma função social e uma função simbólica. Na dimensão de como o território tem sido organizado para responder as necessidades dos agricultores, percebemos que a agricultura convencional foi a que se sobrepôs como modelo produtivo capaz de responder aos anseios de garantia de renda dos agricultores. Neste aspecto, o território acaba por ser reduzido a sua função de produção de alimentos. 
Todavia, as consequências desta agricultura convencional têm sido percebidas na vivência dos agricultores. Durante a pesquisa de campo, foi possível perceber que os agricultores consideram que as suas atividades produtivas impactam negativamente o meio ambiente e uma das maiores preocupações que carregam está relacionada com risco de intoxicações pela aplicação de agrotóxicos. É no cotidiano do cultivo em suas lavouras que percebem os desequilíbrios ecológicos e compartilham suas experiências quanto às técnicas utilizadas. Também é através da convivência que tomam conhecimento das histórias de outros agricultores que adquiriam doenças devido aos anos de aplicação de agroquímicos. É através destas situações de vivência que os agricultores familiares têm conformado a visão sobre o impacto das suas atividades produtivas.

As transformações sobre o uso do território em Brazândia, na direção de fazer emergir uma agricultura de base agroecológica, requer uma ação concertada entre a Emater-DF e os agricultores familiares. Os agricultores familiares são os atores que materializam as práticas agrícolas e a Emater-DF é a instituição governamental responsável por compartilhar conhecimentos sobre técnicas agrícolas. A relação entre a Emater-DF e os agricultores não é no sentido de transferências de pacotes tecnológicos. No caso específico da Emater-DF de Brazlândia, não encontramos uma postura de transferência de pacotes tecnológicos, já que a instituição está disposta a responder aos anseios dos agricultores e a atuação dos técnicos se orienta pelo atendimento das necessidades demostradas pelos próprios agricultores.

Como podemos notar, há um desejo por parte dos agricultores em mudar seus modelos produtivos, porém, entendem que esta mudança depende também de uma ação coletiva. Neste aspecto a impressões captadas confirmam o que a literatura aponta sobre a questão, os agroecossistemas não são sistemas isolados, por isso sofrem influência do meio em que se inserem. A sustentabilidade de todo agroecossistema é dependente também de fatores externos, sendo assim, a transição agroecológica de agroecossistemas em um contexto territorial é motivada por alterações das técnicas agrícolas do coletivo de agricultores.

Por meio de Milton Santos, entendemos que as transformações sobre o território também ocorrem devido à materialização de ações que carregam em si intencionalidades. Estas ações são construídas a partir de um relacionamento dialético entre os sujeitos e o entorno. As condicionantes do meio interferem também sobre a materialidade da ação e, assim, "a intencionalidade da ação se conjuga a intencionalidade dos objetos e ambas são, hoje, dependentes da respectiva carga de ciência e de técnica presente no território" (SANTOS, 2014, p. 94). Por isso não vemos completamente o resultado da ação como 
intencionalizada pelo "fato de que a ação sempre se dá sobre o meio, combinação complexa e dinâmica, que tem o poder de deformar o impacto da ação" (SANTOS, 2014, p.95).

Neste sentido, devemos retomar à análise do contexto em que se insere o espaço rural de Brazlândia para entender quais são os elementos que interferem sobre a construção de um processo de indução ao uso sustentável do território.

Em Brazlândia o modelo de agricultura predominante é o convencional. Este modelo não afeta somente as técnicas de cultivo empregadas, ele também traz consigo um padrão de desenvolvimento para o rural como um todo. Neste sentido, os pequenos agricultores são dependentes de um receituário de técnicas que tem como objetivo aumentar a produtividade e a produção de alimentos. As propriedades são vistas como plantas industriais e os recursos naturais como insumos do processo produtivo. O preço dos alimentos é vulnerável às oscilações de mercado e os grandes e pequenos agricultores disputam de forma igual o espaço no mercado.

$\mathrm{O}$ agricultor que se insere no modelo produtivo da agricultura convencional não encontra incentivos econômicos para alterar o seu modelo produtivo. Os agricultores familiares da comunidade de Chapadinha têm a renda dependente da produção de alimentos e, apesar de sofrerem perdas em seus cultivos quando o preço de determinadas culturas caem, sentem-se receosos em modificar os seus sistemas produtivos, porque entendem que retornos financeiros poderiam aparecer apenas no longo prazo. E, realmente, a transição de modelo produtivos requer uma reserva financeira que pode não estar disponível a todos.

À medida que os centros urbanos do Distrito Federal crescem as áreas rurais adjacentes, destinadas à produção de alimentos, sofrem pressão para abrigar áreas de lazer ou condomínios. Durante as entrevistas, os agricultores relataram que em Chapadinha algumas chácaras deixaram de se dedicar a produção agrícola para se tornar espaço de eventos.

Por isso, entendemos que o processo de desenvolvimento do território em Brazlândia necessariamente se insere em uma totalidade que gera movimentos contraditórios quanto à valorização da função ambiental do território e por vezes tem induzido a dimensão do território a apenas um espaço de produção de alimentos. Neste contexto, o território de Brazlândia acaba por se submeter a uma agricultura de abastecimento para os centros urbanos da Capital Federal.

Em contraposição a este cenário composto por dificuldades para o desenvolvimento de uma agricultura sustentável, as instituição públicas passaram nas duas últimas décadas a configurar políticas de desenvolvimento territorial rural que consideram a dimensão 
ambiental. A modificação do arcabouço legal da Política de Ater e o surgimento de projetos como o Sustentabilidade são exemplos de políticas que fazem parte de uma estratégia política de valorização da agricultura familiar e do seu potencial transformados para resgatar um padrão produtivo agrícola mais sustentável.

O poder público é um ator de grande influência na condução dos processos de desenvolvimento. É o poder público que possui legitimidade política e o aparato burocrático que viabiliza a promoção de políticas públicas que irão impactar em longo prazo os contextos territoriais

A atuação do poder público em Brazlândia é fundamental para que o território siga um processo de desenvolvimento rural onde a dimensão ambiental seja valoriza pela incorporação da agroecologia. Identificamos a Emater-DF como um ator governamental de grande relevância para os agricultores e que muito pode contribuir para materialização das políticas públicas de fomento à agroecologia. O Projeto Sustentabilidade se configurou em uma iniciativa que trouxe avanços para temática. Contudo, a efetividade dessas ações de forma a trazer modificações sobre o padrão produtivo requer que elas sejam desenhadas segundo os contextos dos agricultores.

Durante as entrevistas foi possível perceber que o risco de não garantir a renda em processos de transição agroecológica é um dos fatores observados como impeditivos para incorporação de técnicas agrícolas sustentáveis. Neste sentido, é necessário a formatação de projetos onde o poder público financie o processo de transição agroecológica, e incorpore para si os ricos decorrentes da não manutenção da renda ao longo do processo. Contudo, projetos deste tipo extrapolam o escopo de atuação da Emater-DF, por isso, entendemos que é preciso o envolvimento dos diferentes órgãos responsáveis por construir ações de desenvolvimento rural.

Dessa forma, percebemos que as entidades governamentais, incluindo a Emater-DF, precisam estabelecer ações articuladas que considerem as realidades socioterritorias das comunidades de agricultores de Brazlândia. É preciso entender as dificuldades reais enfrentadas pelos agricultores em uma possível transição agroecológica para que a partir delas sejam configuradas as políticas públicas. 


\section{Considerações Finais}

O desenvolvimento da presente pesquisa foi direcionado pelo seguinte objetivo: analisar o desenvolvimento territorial rural em Brazlândia através do Programa Agroecologia da Emater-DF. Este objetivo implicou na constituição de duas dimensões de análise: o desenvolvimento rural conduzido pelo poder público por meio de políticas públicas e as implicações deste desenvolvimento sobre o território, no que tange a valorização da adoção de práticas agrícolas sustentáveis. Neste sentido, nos preocupamos em contextualizar o caso da política pública da Emater-DF dentro de uma abordagem diferenciada de políticas públicas de desenvolvimento rural que preza pelo fortalecimento da agricultura familiar.

Através dos aportes teóricos da geografia, procuramos nos desviar do reconhecimento dos territórios como unidades espaciais passivas dentro do processo de implementação de políticas para o rural. Por isso, no capítulo três da dissertação, tivemos uma atenção especial ao evidenciar os elementos presentes no contexto territorial de Brazlândia que são críticos para constituição de processos de desenvolvimento, onde a dimensão ambiental tenha um papel relevante.

A análise de como o Programa Agroecologia da Emater-DF contribui com o desenvolvimento territorial rural em Brazlândia, exigiu que a pesquisadora, além de definir o aporte teórico sobre o qual construiria o seu entendimento acerca do desenvolvimento rural, também estudasse o contexto socioespacial de Brazlândia, resgatando eventos importantes para a constituição do espaço rural desta Região Administrativa do Distrito Federal.

Dessa forma, identificamos os fatores relacionados à constituição do território rural de Brazlândia, que fizeram com que ela se destacasse entre as Regiões Administrativas do Distrito Federal pelo quantitativo de agricultores familiares; discutimos a relevância da produção rural para suprir as necessidades de alimentos da região da Capital Federal; identificamos as dificuldades existentes para a transição agroecológica; pontuamos que a modelo de agricultura convencional é antagonista a conformação de contextos favoráveis a processos de desenvolvimento territorial sustentável; e apontamos as perspectivas dos agricultores sobre práticas agrícolas alternativas ou sustentáveis.

A hipótese inicial levantada pela pesquisa foi a de que a política pública de agroecologia da Emater - DF contribui para o desenvolvimento territorial rural de Brazlândia na medida em que induz o uso do território de forma mais sustentável. Não podemos afirmar que a hipótese tenha sido confirmada integralmente. A pesquisa de campo 
revelou que embora os agricultores reconheçam que a Emater-DF, através do Projeto Sustentabilidade, tenha contribuído para uma maior compreensão sobre o impacto das atividades agrícolas no meio ambiente, a empresa efetivamente não induziu uma mudança das técnicas produtiva adotadas, pois entendemos que a transformação dos agroecossistemas não depende apenas da ação de um ator no território.

Os processos de desenvolvimento em um dado território são em boa parte moldados pelas ações de diversos atores, além de serem influenciados pelo meio. Em Brazlândia encontramos uma agricultura de abastecimento já consolidada e que segue os padrões produtivos da agricultura convencional. Assim, identificamos que este contexto é desfavorável para a modificação das técnicas produtivas em direção a uma agricultura de base agroecológica.

Todavia, o Projeto Sustentabilidade foi uma importante ação de conscientização sobre as consequências das técnicas produtivas da agricultura convencional sobre o meio ambiente e a saúde do homem. Durante as entrevistas, foi possível constatar que o uso de agrotóxicos é reconhecido por boa parte dos agricultores como uma técnica prejudicial para sustentabilidade dos agroecossistemas.

Embora a ação da Emater-DF não tenha provocado uma mudança concreta sobre o uso do território, ela foi importante para corroborar com outros processos que impulsionam a adoção de práticas sustentáveis no cultivo de alimentos. Nesta questão, torna-se relevante a existência de outros estudos com o foco de identificar outras ações, não só aquelas promovidas pelo poder público, que carreguem intencionalidades afetas a indução de processos de desenvolvimento sustentável.

Como discutimos no capítulo 2, o desenvolvimento sustentável é uma noção relevante para construção de contextos que promovam uma relação harmônica entre o homem e o meio natural. Todavia esta noção apresenta múltiplos significados, os quais dependerão dos atores que farão uso dela. Quando analisamos a política de Ater, percebemos que o seu discurso de desenvolvimento sustentável, em boa parte, está atrelado ao estímulo à agroecologia. As análises futuras das ações no território rural de Brazândia deverão identificar o entendimento acerca do desenvolvimento sustentável transmitido por cada ator.

Durante desenvolvimento da pesquisa, por meio da aplicação das entrevistas juntos aos agricultores e os técnicos da Emater-DF, conseguimos identificar alguns elementos constitutivos do entendimento sobre o desenvolvimento sustentável desses atores. A EmaterDF, embora receba diretrizes quanto ao fomento da agroecologia, apresentou uma atuação 
muito focada no aspecto da melhoria das práticas agrícolas. É possível justificar este enfoque devido à realidade do perfil dos agricultores desta região, os quais nem sempre fazem o uso racional dos insumos da agricultura convencional. Nesta questão, entendemos que a EmaterDF, no caso de Brazlândia, veiculou a percepção de que os agrossistemas são otimizados pelo uso racional dos insumos e pela adoção de práticas que agridem menos os recursos naturais. Dessa forma, o desenvolvimento sustentável acaba por ser entendido pelo seu aspecto de melhoramento das técnicas existentes, seguindo uma abordagem ecotecnocrática, como discorre Coporal e Costabeber (2000). Neste sentido, a atuação da empresa acabou por se forcar no aspecto produtivo do território rural, diminuindo a importância da dimensão ambiental no desenvolvimento das atividades de assistência técnica junto aos agricultores.

Os agricultores, por sua vez, apresentam uma preocupação em relação ao desgaste dos recursos naturais e aos riscos à saúde, apontam o orgânico como modelo ideal de produção agrícola. Ao se depararem com as consequências da agricultura convencional, reconhecem que ela não é o melhor modelo, todavia, ainda não sabem como a agroecologia poderia contribuir.

A preferência maior em relação ao orgânico é decorrente da possibilidade de sanar os riscos de contaminação, tanto do meio natural quanto do ser humano, provenientes dos agrotóxicos. Neste sentido, por meio do entendimento apresentado pelos agricultores, a sustentabilidade em sistemas agrícolas está associada ao não desgaste dos recursos naturais, a proteção da saúde do homem e a biodiversidade dos ecossistemas. É importante ressaltar que fazemos esta afirmação com base nas conversas tidas nas entrevistas, já que o termo "sustentabilidade" não é de conhecimento de todos. Todavia a agroecologia ainda não é reconhecida por parte dos agricultores como uma ciência capaz de auxiliar processos de transição para modelos de produção agrícola mais sustentáveis, dentre os quais estão a agricultura orgânica. É importante ressaltar que durante pesquisa de campo, devido ao baixo conhecimento dos agricultores em relação à agroecologia, ou mesmo, ao termo sustentabilidade, tivemos que durante a aplicação dos questionários associar a questão das práticas agrícolas sustentáveis ao modelo de produção orgânica. Isso também ocorreu porque os agricultores se mostraram mais familiarizados com a agricultura orgânica do que com outros modelos de produção sustentável.

Ainda no que diz respeito à pesquisa de campo, seu caráter foi qualitativo, sendo assim, buscou retratar apenas um caso específico sem ter pretensões de sugerir que as conclusões apresentadas neste trabalho fossem expandidas para outros contextos. Ainda é 
importantes salientar, que análise da atuação da Emater-DF se concentrou no Programa Agroecologia desenvolvido pela instituição em um corte de tempo e espaço definidos, por isso não nos preocupamos em trazer sugestões para a melhoria da atuação da empresa como um todo.

Um dos objetivos específicos definidos no início da pesquisa foi: analisar a influência do Programa Agroecologia na territorialidade dos agricultores de Brazlândia. A operacionalização deste objetivo foi comprometida pelas características da intervenção pública estudada. O Programa Agroecologia da Emater-DF não apresenta um conjunto de ações coordenadas no território rural de Brazlândia, a experiência do Projeto Sustentabilidade teve um caráter transitório e, até a finalização desta pesquisa, não identificamos outras ações semelhantes a essa em curso. Tal situação dificultou para que identificássemos de que forma a Emater-DF influenciou o uso e a apropriação do território por parte dos agricultores.

Outro aspecto importante da pesquisa, que devemos destacar para a construção de projetos de pesquisa posteriores, se refere à necessidade de estudar as ações dos agricultores também em sua dimensão coletiva. A pesquisa de campo concentrou os seus esforços na análise individual da percepção dos agricultores no que se refere à atuação da Emater-DF e às práticas agrícolas sustentáveis. Torna-se oportuno entender a agricultura familiar de Brazlândia em sua dimensão coletiva, para assim formatar uma análise do ator coletivo do território. Neste sentido, entende-se que os atores coletivos estão expressos nas organizações de representação dos agricultores, como a Associação de Produtores Rurais da Reserva A (APA) na Chapadinha. Tais organizações são constituídas com o propósito de alcançar fins comuns, que podem incluir projetos simples como a compra de maquinários para uso coletivo ou até projetos mais complexos que envolveram o compartilhamento de estruturas produtivas em modelos cooperativos. Os princípios de reciprocidade e bem comum tendem a ser presentes na atuação dessas organizações. Além disso, por meio do estudo dos atores coletivos conseguirmos entender em que sentido são estabelecidas as relações entre os agricultores de forma a fazer uso do território.

Por fim, precisamos pontuar que o cenário político do momento atual pode interferir sobre o curso dos processos de desenvolvimento rural impulsionados pela valorização da agricultura familiar. As políticas públicas dependem em grande medida dos interesses políticos que irão formatar a agenda política da ação governamental. Nos últimos anos observamos a constituição de um contexto institucional para implementação de políticas públicas, onde se criaram mecanismo de fortalecimento da agricultura familiar, dentro de uma 
abordagem diferenciada de políticas públicas de desenvolvimento rural, discutidas no capítulo 1 desta dissertação. Estruturas de governo, aparatos legais, programas especificamente desenhados para agricultura familiar, fortalecimento da política de Ater e valorização da agroecologia, são exemplos dos elementos que constituem a abordagem diferenciada de políticas públicas de desenvolvimento rural que emergiu na década de 1990. Todavia a crise política que enfrentamos neste momento, culminando na reformatação da atuação governamental, começa a apontar que a valorização da agricultura familiar pode perder importância dentro da agenda governamental e os territórios rurais correm o risco de serem vistos apenas pelo seu aspecto agrícola de produção. Não podemos afirmar ao certo como serão as políticas para o rural dos próximos anos, porém é preciso ressaltar que a abordagem territorial das políticas para agricultura familiar, estruturada nas últimas décadas, permitiu a existência de Programas como o Agroecologia da Emater-DF, que apesar de ainda ter desafios a serem enfrentados, contribuiu para trazer a importância das práticas agrícolas sustentáveis para questão do desenvolvimento rural. 


\section{Referências Bibliográficas}

ABRAMOVAY, Ricardo. Para uma teoria dos estudos territoriais. In: ORTEGA, Antonio César \& ALMEIDA Filho, Niemeyer (org.). Desenvolvimento territorial: segurança alimentar e economia solidária. São Paulo, Alínea, 2007. . O futuro das regiões rurais. Porto Alegre: Editora da UFRGS, 2009.

ALMEIDA, Sílvio Gomes de. Construções e desafios do campo agroecológico brasileiro. In: PETERSEN, Paulo (org.). Agricultura camponesa na construção do futuro. Rio de Janeiro: AS-PTA, 2009.
ANUÁRIO
DO
DISTRITO
FEDERAL.
Disponível
em: http://www.anuariododf.com.br/regioes-administrativas/ra-iv-brazlandia/>.

ARAUJO, Tania Bacelar de. A experiência de planejamento regional no Brasil. In: Lavinas, Lena et alli. Reestruturação do espaço urbano e regional no Brasil. São Paulo, Hucitec, 1993.

ARRETCHE, Marta. Tendências no Estudo sobre Avaliação. In: RICO, Elizabeth Melo (org.). Avaliação de Políticas Sociais: Uma Questão em Debate. São Paulo, Cortez, 1998.

BONNEMAISON, Jöel. Viagem em torno do território. In: CORRÊA, Roberto Lobato \& ROSENDAHL, Zeny (org). Geografia Cultural. Uma Antropologia. Volume I. Ed Uerg. Rio de Janeiro. 2012.

BRASIL. Política Nacional de Assistência Técnica e Extensão Rural. Ministério do Desenvolvimento Agrário. 2007. Disponível em: <http://www.mda.gov.br/sitemda/sites/sitemda/files/user_arquivos_64/Pnater-4.doc>. Acessando em: 12 de fev. 2015.

BRASIL. Edital Chamada Pública para Seleção de Entidades Executoras de Assistência Técnica e Extensão Rural para Promoção da Agricultura Familiar Sustentável. Ministério do Desenvolvimento Agrário, 2012.

BRESSER PEREIRA, Luiz Carlos. Estratégia e estrutura para um novo Estado. REVISTA DE ECONOMIA POLÍTICA, v. 17, n.3 (67), jul./set., 1997. Disponível em: <http://www.rep.org.br/pdf/67-3.pdf>. Acessado em: 20 jan. 2015.

CAMPOS, Neio \& KRAHL, Mara Flora Lottici. Territorialidade: elo entre o espaço rural e urbano. In: STEINBERGER, Marília. (org.). Território, Ambiente e Políticas Públicas Espaciais. $1^{\mathrm{a}}$ ed. Brasília/DF: LGE Editora, 2006. 
CANDIDO, Antônio. As formas de solidariedade. In: Os parceiros do Rio Bonito: estudo sobre o caipira paulista e a transformação dos seus meios de vida. Rio de Janeiro: José Olympio, 1964.

CAPORAL, Francisco Roberto \& COSTABEBER, José Antônio. Agroecologia $e$ desenvolvimento rural sustentável: perspectivas para uma Nova Extensão Rural. Agroecologia e desenvolvimento rural sustentável, Porto Alegre, v.1, n1, jan./mar. 2000.

Agroecologia e extensão rural: contribuições para a promoção do desenvolvimento rural sustentável. Brasília: MDA/SAF/DATER-IICA,2004.

CARVALHO, João Luiz Homem de (org). A agricultura no Distrito Federal (1995/1998): Novas formas de intervenção do Estado para um novo modelo de desenvolvimento rural. Brasília: Secretaria de Agricultura, 1998.

CASTELLS, Manuel. A sociedade em rede - A era da informação: economia, sociedade e cultura. v.1. São Paulo: Paz e Terra, 1999.

CASTRO, Manoel Cabral de. Desenvolvimento Sustentável. O debate teórico e importância nas políticas públicas da Amazônia”. Capítulo 2. Tese de Livre-Docência. ESALQUSP. 2007

CHAVES, Weber José Neiva. Brazlândia, agricultura e identidade: fragarias da festa do morango e da reificação triunfante da mercadoria ao simulacro e a venda sem charme dos ambulantes. Universidade de Brasília, 2011. Dissertação de mestrado.

CODEPLAN. Companhia de Planejamento do Distrito Federal. Coletânea de Informações Socioeconômicas - Região Administrativa de Brazlândia. 2007.

CODEPLAN. Companhia de Planejamento do Distrito Federal. Agricultura familiar no Distrito Federal: dimensões e desafios. 2015(a). Disponível em: http://www.codeplan.df.gov.br/images/CODEPLAN/PDF/pesquisa_socioeconomica/pol iticas_sociais/2015/Agricultura_Familiar_no_DF.pdf. Acessado em: 02 de fev. 2016.

CODEPLAN. Companhia de Planejamento do Distrito Federal. O mercado de produtos orgânicos: mecanismos de controle. 2015(b). Disponível em: http://www.codeplan.df.gov.br/images/CODEPLAN/PDF/pesquisa_socioeconomica/pol iticas_sociais/2015/Mercado_Produtos_Organicos_2015.pdf. Acessado em: 05 de abr. 2016.

CODEPLAN. Companhia de Planejamento do Distrito Federal. Pesquisa Distrital por Amostra de Domicílios - PDAD 2015 - Brazlândia (c). Disponível em: 
<http://www.codeplan.df.gov.br/component/content/article/261-pesquisassocioeconomicas/319-pdad-2015.html>. Acessando em: 07 de jul. 2015.

CODEPLAN. Companhia de Planejamento do Distrito Federal. Estudo urbano ambiental Brazlândia. 2015(d)

COSTA, Gilney de Araújo. Conflitos socioambientais na dinâmica do uso do território na sub-bacia do córrego Chapadinha/Brazlândia/DF. Universidade de Brasília, 2015. Dissertação de Mestrado.

COSTA, Wanderley Messias. O Estado e as políticas territoriais no Brasil. São Paulo, Edusp/ Contexto, 2000.

DELGADO, Nelson; Leite, Sérgio Pereira. Atualização das Políticas de Desenvolvimento Territorial no meio rural brasileiro. In: MIRANDA, Carlos; Tiburcio, Breno (org.). Políticas de desenvolvimento territorial e enfrentamento da pobreza rural no Brasil. Brasília: IICA, 2013, Série Desenvolvimento Rural Sustentável, v.19, pp 125-148.

DIAS, Marcelo Miná. As mudanças de direcionamento da Política Nacional de Assistência Técnica e Extensão Rural (PNATER) face ao difusionismo. REVISTA OIKOS, Viçosa, v. 18, n.2, p.11-21. 2007.

EHLERS, Eduardo. Agricultura Sustentável, Origens e perspectivas de um novo paradigma. $2^{\circ}$ Ed. revisada e atualiza. São Paulo: Livraria e Editora Agropecuária, 1999.

EMATER -DF. Emater-DF 30 anos. Ensinando e aprendendo. Brasília, 2008.

EMATER -DF. Programa de Agroecologia. Brasília, 2010. Disponível em:

$<$ http://www.emater.df.gov.br/index.php?option=com_content\&view=article\&id=65\&It emid=79 > . Acessado em: 14 de set. 2015.

EMATER-DF. Índice de desenvolvimento rural comunitário: comunidade orla do Descoberto. 2011. Disponível em:

$<$ http://www.emater.df.gov.br/index.php?option=com_content \&view=article\&id=71\&It emid=85>. Acessado em: 14 de set. 2015.

EMATER-DF. Índice de desenvolvimento rural comunitário: comunidade Chapadinha. 2011. Disponível em: $<$ http://www.emater.df.gov.br/index.php?option=com_content\&view=article\&id=71\&It emid=85>. Acessado em: 14 de set. 2015.

FAVARETO, Arilson da Silva. Paradigmas do Desenvolvimento Rural em Questão - do Agrário ao Territorial. 2006. Tese de doutorado. Programa de Pós Graduação em Ciência Ambiental. Universidade de São Paulo. Disponível em: 
<http://www.teses.usp.br/teses/disponiveis/90/90131/tde-24042008-113514/pt-br.php>. Acessado em: 20 de jan. de 2015.

FEIDEN, Alberto. Agroecologia: introdução e conceitos. In: AQUINO, Adriana Maria de \& ASSIS, Renato Linhares de. Agroecologia: princípios e técnicas para uma agricultura orgânica sustentável. Brasília -DF, Embrapa Informação Tecnológica, 2005.

FILIPPI, Eduardo Ernesto. O desenvolvimento rural no Brasil: das politicas de estado às politicas territoriais. In: BONNAL, Philippe \& LEITE, Sérgio (org.) Análise Comparada de Políticas Públicas. Uma agenda em transformação. Rio de Janeiro: Mauad X, 2011.

GLIESSMAN, Stephen. Agroecologia. Processos ecológicos em Agricultura Sustentável. Porto Alegre: Ed. Universidade/UFRGS, 2001.

GOLDSMITH, Stephen \& EGGERS, William D. Governar em rede: o novo formato do setor público. São Paulo: Editora da UNESP, 2006.

GOMES, João Carlos Costa. Bases epistemológicas da agroecologia. In: AQUINO, Adriana Maria de \& ASSIS, Renato Linhares de. Agroecologia: princípios e técnicas para uma agricultura orgânica sustentável. Brasília -DF, Embrapa Informação Tecnológica, 2005.

GRAZIANO DA SILVA, José. A modernização dolorosa - Estrutura agrária, fronteira agrícola e trabalhadores rurais no Brasil. Rio de Janeiro : Zahar, 1981. . O novo rural brasileiro. REVISTA NOVA ECONOMIA, Belo horizonte. 7(1):43-81 (maio de 1997). Disponível em: http://www.geografia.fflch.usp.br/graduacao/apoio/Apoio/Apoio_Valeria/Pdf/O_novo_r ural_brasileiro.pdf.

GRAZIANO DA SILVA, José \& CAMPANHOLA, Clayton (editores técnicos). O Novo Rural Brasileiro - Novas Ruralidades e Urbanização. Brasília, DF: Embrapa Informação Tecnológica, 2004

GUZMÁN, Eduardo Sevilla. Agroecologia e desenvolvimento rural sustentável. In: AQUINO, Adriana Maria de \& ASSIS, Renato Linhares de. Agroecologia: princípios e técnicas para uma agricultura orgânica sustentável. Brasília -DF, Embrapa Informação Tecnológica, 2005.

HESPANHOL, Rosângela de Medeiros. Agroecologia: limites e perspectivas. In: ALVES, Adilson Francelino; CARRIJO, Beatriz Rodrigues \& CANDIOTTO, Luciano Zanetti Pessôa (org). Desenvolvimento territorial e agroecologia. São Paulo, Expressão Popular, 2009. 
INOJOSA, Rose Marie. Sinergia em políticas e serviços públicos: desenvolvimento social com intersetorialidade. CADERNOS FUNDAP, n. 22, 2001, p. 102-110.

KLIJN, E. H. Redes de políticas públicas: uma visión general. 1998. Disponível em: http://revista-redes.rediris.es/webredes/textos/Complex.pdf.

JESUS, Eli Lino de. Diferentes abordagens de agricultura não-convencional: história e filosofia. In: AQUINO, Adriana Maria de \& ASSIS, Renato Linhares de. Agroecologia: princípios e técnicas para uma agricultura orgânica sustentável. Brasília -DF, Embrapa Informação Tecnológica, 2005.

LAGO, Luiz Aranha Corrêa do. A retomada do crescimento e as distorções do "milagre": 1967-1973. In: Abreu, Marcelo de Paiva et all., A ordem do progresso: cem anos de política econômica republicana 1889-1989. Rio de Janeiro: Campus, 1990.

MACHADO, Felipe da Silva. O rural na gestão das políticas territoriais: questões teóricometodológicas. ANAIS DO I CONGRESSO BRASILEIRO DE GEOGRAFIA POLÍTICA, GEOPOLÍTICA E GESTÃO DO TERRITÓRIO, 2014. Rio de Janeiro. Porto Alegre: Editora Letra1; Rio de Janeiro: REBRAGEO, 2014, p. 1164-1171.

MALUF, Renato. Elementos para uma agenda pública de enfrentamento da pobreza e inclusão socioprodutiva no meio rural na ótica do desenvolvimento territorial sustentável. In: MIRANDA, Carlos \& TIBURCIO, Breno (org.). Políticas de desenvolvimento territorial e enfrentamento da pobreza rural no Brasil. Brasília: IICA, 2013, Série Desenvolvimento Rural Sustentável, v.19, pp. 57-124.

MERTENS, D. M. \& Wilson, A. T. Program evaluation theory and practice: A comprehensive guide. New York, NY: Guilford, 2012.

MARINE, Caio \& MARTINS, Humberto. Um governo matricial: estruturas em rede para geração de resultados de desenvolvimento. Disponível em: <http://conscienciafiscal.mt.gov.br/arquivos/A_8bbc987afebbbba069e69ed8fcedb290go vmatricial.pdf >. Acessado em: 05 de ago. 2014.

MERTENS, Donna \& WILSON, Amy. Program, Evaluation, Theory and Practice. New York, The Guilford Press, 2012.

MIRANDA, Carlos e Silva, Heithel. Concepções da ruralidade contemporânea: as singularidades brasileiras. SÉRIE DESENVOLVIMENTO RURAL SUSTENTÁVEL; v.21. Brasília: IICA, 2013.

NAVARRO, Zander. Desenvolvimento rural no Brasil: os limites do passado e os caminhos do futuro. ESTUDOS AVANÇADOS. v.15, n. 43, 2001. Disponível 
em:<http://www.scielo.br/scielo.php?pid=S0103-

40142001000300009\&script=sci_arttext $>$. Acessado em: 20 de jul. de 2015.

OLIVEIRA, Ariovaldo Umbelino de. Modo capitalista de produção e agricultura. São Paulo: Ática, 1987.

A mundialização da agricultura brasileira. XII Coloquio Internacional de Geocrítica. Bogotá, maio de 2012. Disponível em: <http://www.ub.edu/geocrit/coloquio2012/actas/14-A-Oliveira.pdf>. Acessado em: 16 de jun. 2016.

OLIVEIRA, Maria Neuza da Silva. Agricultura e sustentabilidade nos núcleos rurais da bacia hidrográfica do Ribeirão Pipiripau. Centro de Desenvolvimento Sustentável - CDS, Universidade de Brasília - UnB, 2006. Dissertação de mestrado.

PUTNAM, Robert. Capital social e democracia. BRAUDEL PAPERS, $\mathrm{n}^{\circ}$ 10, 1995. Disponível em: http://pt.braudel.org.br/publicacoes/braudel-papers/10.php. Acessado em: 24 de julho de 2015.

REBELO JUNIOR, Manoel. Os núcleos rurais do Distrito Federal. Campina Grande, 1992. Dissertação de Mestrado. Universidade da Paraíba.

REFFESTIN, Claude. Por uma geografia do poder. São Paulo, Editora Ática, 1993.

SABOURIN, Eric. Multifuncionalidade da agricultura e manejo dos recursos naturais: alternativas a partir do caso do semi-árido brasileiro. Revista Tempo da Ciência, n.29, vol.15. Toledo: Unioeste, 2008. p.9-27. Camponeses do Brasil: entre a troca mercantil e a reciprocidade. Rio de Janeiro: Garamond, 2009.

SANTOS, Milton. Espaço e Método. São Paulo: Nobel, 1985. . O retorno do território. In: SANTOS, Milton; SOUZA, Maria Adélia de \& SILVEIRA, Maria Laura (org). Território: globalização e fragmentação. São Paulo: Hucitec, 1998.

A Natureza do Espaço. São Paulo, Editora da Universidade de São Paulo, 2014.

SAQUET, Marcos Aurelio. Agricultura camponesa e práticas (agro)ecológicas. Abordagem territorial histórico-crítica, relacional e pluridimensional. Mercator, Fortaleza, v. 13, n. 2, p. 125-143, mai./ago. 2014. 
SCHMITT, Cláudia Job \& TYGEL, Daniel. Agroecologia e Economia Solidária: trajetórias, confluências e desafios. In: PETERSON, Paulo (org). Agricultura camponesa na construção do futuro. Rio de Janeiro: AS-PTA, 2009.

SCHNEIDER, Sérgio. A abordagem territorial do desenvolvimento rural e suas articulações externas. SOCIOLOGIAS, Porto Alegre, ano 6, nº 11, p. 88-125, jan/jun 2004.

SEN, Amartya. Desenvolvimento como liberdade. São Paulo: Companhia das Letras, 2001.

SILVA, Heliton Leal. Desenvolvimento agrícola, gestão do território e efeitos sobre a sustentabilidade na região Centro-Oeste, Brasil. Tese de Doutorado em Desenvolvimento Sustentável. Universidade de Brasília, Brasília, 2008.

STEINBERGER, Marília. Território, Ambiente e políticas públicas espaciais. In: STEINBERGER, Marília (org.). Território, Ambiente e Políticas Públicas Espaciais. $1^{\mathrm{a}}$ ed. Brasília/DF: LGE Editora, 2006.

VASCONCELOS, Adirson. As cidades satélites de Brasília. Brasília, Centro Gráfico do Senado Federal, 1988.

VEIGA, José Eli da. Desenvolvimento sustentável: o desafio do século XXI. Rio de Janeiro, Garamond, 2010.

. "Pobreza Rural, Distribuição da Riqueza e Crescimento: a experiência brasileira”. In: TEÓFILO, Edson (org.) et alli. Distribuição de Riqueza e Crescimento Econômico. Brasília: Núcleo de Estudos Agrários e Desenvolvimento Rural/Conselho Nacional de Desenvolvimento Rural Sustentável / Ministério do Desenvolvimento Agrário, 2000, pp. 173 -200.

- O Brasil rural ainda não encontrou seu eixo de desenvolvimento. ESTUDOS AVANÇADOS, São Paulo, v.15 n.43, Set./Dez. 2001. Disponível em: <http://www.scielo.br/scielo.php?pid=S0103-40142001000300010\&script=sci_arttext >. Acessado em: 07 de out. de 2012.

WANDERLEY, Maria Nazaré. Agricultura familiar e campesinato: rupturas e continuidade. Texto preparado para a Aula Inaugural do primeiro semestre de 2004 a ser ministrada no CPDA/UFRRJ. Disponível em: http://r1.ufrrj.br/esa/V2/ojs/index.php/esa/article/view/238. Acessado em: 22 de abr. 2016. 
Anexos 


\section{ANEXO I - Roteiro de entrevista semiestruturado ao coordenador do Programa Agroecologia da Emater-DF}

1. Quais os motivos levaram a criação deste programa?

2. Por que o Programa de Agroecologia está entre os prioritários da Emater-DF?

3. Quais as estratégias e suposições levantadas no momento de criação do programa?

4. Quais foram as necessidades percebidas nos agricultores que justificaram o desenvolvimento de um programa como este?

5. Quais são as potencialidades/características dos agricultores que têm contribuído para um bom desenvolvimento do programa?

6. Quais são os objetivos do programa?

7. De que maneira são considerados os fatores locais, tais como: o associativismo/organização comunitária, as características do ecossistemas, as práticas tradicionais de cultivo, no desenvolvimento dos planos de ação?

8. Quais princípios da agroecologia poderiam ser identificados no programa?

9. Quais são os resultados desejados (outputs, outcomes e impactos)?

10. Como tem sido o relacionamento com o MDA para execução do programa? De que maneira o MDA interfere na gestão do programa - estabelecimento de diretrizes, monitoramento, etc? Há repasse de recursos?

11. Quais são os fatores de influência sobre o programa?

12. Que ações compõem os dois eixos do programa - transição agroecológica e desenvolvimento de sistemas agroecológicos de produção?

13. Como tem sido o desenvolvimento do Programa em Brazlândia? 


\section{ANEXO II - Roteiro de entrevista semiestruturado aplicado aos escritórios locais da Emater-DF em Brazlândia}

1. Como o programa Agroecologia tem se relacionado com as atividades corriqueiras? De que forma ele tem sido incorporado por este escritório local?

2. Quais são os objetivos do Programa aqui em Brazlândia?

3. Em que consistiu o Projeto Sustentabilidade aqui em Brazlândia? Quais foram as atividades desenvolvidas?

4. Quais dificuldades enfrentadas para o desenvolvimento do Projeto Sustentabilidade?

5. Como o Programa Agroecologia e o Projeto Sustentabilidade têm contribuído para mudança de percepção dos agricultores quanto às práticas agrícolas até então desenvolvidas?

6. De que maneira a agroecologia influência a assistência aos agricultores?

7. Em seu ponto de vista, quais seriam os principais fatores que impendem a adoção de um modelo produtivo agroecológico por parte dos agricultores?

8. Aqui em Brazlândia você entende que a agroecologia tem potencial de incorporação pelos agricultores?

9. Qual o seu entendimento sobre a tendência das práticas agrícolas sustentáveis aqui em Brazlândia? 


\section{ANEXO III - Roteiro de entrevista semiestruturado aplicado aos agricultores que participaram do Projeto Sustentabilidade na Chapadinha, Brazlândia}

$\mathrm{N}^{\mathrm{o}}$ da entrevista:

Informações de identificação da entrevista

Data:

Família:

Localidade:

Nome do entrevistado(a):

Sexo:

Idade:

1. Porque você se tornou agricultor?

2. O que levou você e a sua família a escolher Brazlândia para morar e desenvolver as suas atividades produtivas?

3. Você se imagina exercendo outra profissão?

4. A renda da sua família depende da produção da sua propriedade? Há outras atividades não agrícolas ou benefícios sociais que auxiliam na complementação da renda? Se sim, quais seriam?

5. Você acredita que as suas atividades agrícolas interferem na conservação dos recursos naturais aqui de Brazlândia? Se sim, de que forma?

6. Desde quando você tem sido atendido pela Emater-DF? De que maneira a empresa tem lhe apoiado? Quais atividades promovidas pela empresa você e sua família já participaram?

7. As atividades desenvolvidas pela empresa sobre práticas agrícolas sustentáveis têm influenciado a sua visão sobre o cultivo de alimentos aqui em sua propriedade?

8. Quais técnicas você passou a utilizar em sua propriedade após participar do Projeto Sustentabilidade?

9. Participar do projeto sustentabilidade lhe fez pensar um pouco mais sobre os cuidados com o meio ambiente?

10. Você acredita que práticas agrícolas mais sustentáveis podem trazer um retorno financeiro equivalente aos das práticas agrícolas convencionais?

11. Qual a sua compreensão sobre a agroecologia?

12. Você desejaria ter um modelo produtivo mais sustentável, no qual não necessitaria de insumos externos a sua propriedade? Se sim, quais seriam as dificuldades e facilidades enfrentadas na mudança de seu modelo produtivo? Você acredita que a Emater-DF poderia ajudar neste processo? 


\section{ANEXO IV - Transcrição das entrevistas com os agricultores}

\section{Entrevista $n^{0} 1$}

\section{Data de realização da entrevista:}

Duração: 23'53',

Por que que você e seu esposo se tornaram agricultores? Por que vocês decidiram ter essa profissão?

No caso ele já nasceu na roça, foi criado na roça, né. Toda vida ele sempre foi agricultor. Agora quando eu conheci ele, eu morava na cidade. Quando eu conheci casei, já fui pra roça e já virei uma plantadeira, como diz os meninos. Virei agricultura depois que casei, aí peguei o gosto também. Apesar de que eu venho de família que o pessoal tudo morava na roça, nas fazendas né, só meu pai foi morar na cidade para poder colocar os filhos para estudar. Aí a gente saiu da roça por isso. Mas depois que eu casei, tenho 34 anos de casada. Depois de casada, toda vida mexendo na roça. Mudamos para o estado do Pará, mas continuamos na fazenda. Lá a gente mexia com pecuária porque para lá já é outro perfil.

O que levou vocês virem para cá? Passar a morar aqui? Vocês chegaram em Brazlândia já para produzir?

Foi já para produzir. A gente veio pra cá com essa intenção de produzir. Nós compramos a chácara aqui, vendemos a fazenda de lá e compramos essa aqui já para plantar mesmo.

Vocês venderam a fazenda do Pará para vir para cá? O que levou vocês a fazerem essa decisão?

Porque os filhos cresceram, e cada um foi tomar conta da sua vida. $\mathrm{O}$ filho mais velho casou, aí ficou o outro mais novo, já tava já terminando, concluindo os estudos dele, e a gente decidiu vir para cá, porque a gente já era daqui, no Incra 9. Quando a gente morava aqui a gente já plantava de meeiro. Aqui gente não tinha terra na época, era meeiro, tanto a minha sogra, todo mundo, a gente plantava de meeiro. A gente não tinha terra. Quando a gente mudou para o Pará, lá gente conseguiu. Foi mais fácil através de lá a gente conseguiu comprar. Agente vendeu tudo que tinha lá e comprou aqui.

\section{Então a sua família já era aqui de Brasilândia desde a década de 1960?}

A família dele. A minha era lá do Goiás. A família dele já morava toda aqui nos anos 70 . Uns vieram na década de 60 e outros já vieram em 75, por aí. Mas a família dele todinha tá aqui, todo mundo tem chácara todo mundo é agricultor.

\section{Então vocês estavam no Incra 9 e...}

Quando eu sair de casa a gente morava no Incra 9. Aí moramos 10 anos lá plantando de meeiro. Nós éramos meeiro, a gente não tinha terra, era ralando mesmo assim. Aí a gente resolveu morar no Pará, com intenção de plantar horta lá nosso nós fomos para a fazenda do meu irmão. mas lá o clima não deu certo para horta, muito quente e úmido e faltou água também. aí lá não deu certo para a gente plantar. A gente tentou demais aí a gente foi mexer com gado, vaca leiteira, pecuária.

Aí lá no Pará com a pecuária, vocês conseguiram fazer economias e vir para cá? 
Aham. Aí a gente veio para cá e comprou. Depois de um ano a gente comprou e a gente mudou e veio para cá.

\section{Hoje em dia, você se imagina exercendo outra profissão?}

Não, não. A gente mesmo essa semana, tava falando. A gente não consegue pensar em outra vida. É essa aqui mesmo, muito bom. Aqui se não fosse o medo que a gente tem de bandido, de assalto essas coisas, era tudo $100 \%$. É só isso que ainda causa muito medo assim na gente, ainda é só isso.

\section{Aqui... Tem assalto nessa região?}

Aqui é demais, eles entram arromba, arrebenta as portas e entra dentro para amarrar todo mundo e rouba tudo que tem. Já matou gente aqui. É direto. Agora dois anos para cá, aquietou um pouco. Mas teve dois meses, em dois meses com 22 ocorrências. Causa terror, até queimar gente com ferro para poder pegar dinheiro eles queimavam. Botava ferro para esquentar e queimava as pessoas. É só isso, essa parte ruim, é só isso. Mas o resto.

\section{Então você pensa assim que futuramente você sempre será agricultora?}

Isto é, sempre agricultora mesmo. Agora a gente tá mudando, a gente vai plantar mais agora é fruta, porque a nossa terra está muito cansada já para hortaliça. Estamos começando a mudar, vamos plantar goiaba. A gente vai mexer com fruta agora porque nessas terra velha né? Até o pessoal da Emater falou: essa terra ficando cansada, o melhor e plantar fruta..

\section{A renda da sua família depende da produção da sua propriedade? Depende inteiramente?}

Aqui para nós é, depende inteiramente dela. Porque meu filho tem a vida dele. Mas eu, o outro que é solteiro, a gente mantém ele também, os estudos dele lá para lá. Então depende da renda daqui da propriedade.

\section{Existe outras atividades que complementam a renda?}

Não. É só agricultura.

\section{Você planta aqui hortaliças. Você tem outro tipo de plantação aqui?}

Não, não, só hortaliça. Agora a gente tá tentando mudar para goiaba, mexer mais só com fruta, adaptando, porque passar da hortaliça para fruta já demora mais porque a fruta é 2, 3 anos para poder começar a produzir. Então a gente já tem que tá plantando hortaliças e já cuidando de cultivar as frutas que vai começar a chegar agora as mudas.

\section{Então você já planta morango aqui?}

Planto.

Você acredita que as atividades aqui desenvolvidas na sua propriedade interferem na conservação dos recursos naturais aqui de Brasilândia?

Se não, não interfere. Você fala assim se agride alguma coisa?

\section{Isso, isso}

Eu acho que não. Agente faz tudo assim como indicado. Como a Emater tem instruído a gente né? Então eu acho que não. A gente não deixa resíduo assim. Toda a embalagem que usa a gente já retorna para o lugar aonde que entrega embalagens. Essas coisas produto, veneno, essas coisas... Por exemplo, agrotóxico mesmo a gente leva tudo. A gente tem um lugarzinho 
para guardar a embalagens, aqui que fica juntando e guarda as embalagens né? Para levar no lugar aqui pertinho de Brasilândia. Então a gente é cadastrado para já não causar impacto mesmo E também o meu marido tá usando muito orgânico. Ele tá passando muito para o orgânico, ele quase não usa, ele não gosta de veneno.

Ele tá passando por uma transição para o orgânico?

É isso. Ele usa muita coisa orgânica. A gente só não é orgânico, porque você sabe... para você ser orgânico, eh... você tem muitos trâmites para você passar ser orgânico. A certificação é muito difícil para obter.

Vocês falaram que vocês acatam muito das orientações que a Emater passa, você tem incorporado muitas orientações aqui na propriedade?

Tem

Também no descarte das embalagens?

Isso

Na forma de cultivo?

Isso, tudo. Eles dão muito curso para gente.

Desde quando você tem sido atendida pela Emater?

Desde quando a gente se mudou para cá. Já tem 7 anos, fazendo 8 anos agora. Então a gente sempre tá tendo assistência deles. Qualquer coisa que a gente precisa a gente vai e eles estão sempre prontos a atender para ajudar a gente. A gente tem uma assistência muito boa da Emater, muito boa mesmo.

E de que maneira a Emater tem apoiado você? De que forma eles apoiam?

Eles dão cursos. agente precisa a gente pede eles E eles dão curso também. para parte também de financiamento. tudo eles tem apoiado a gente. assim é total. Agente não tem o que reclamar. Eles dão o apoio para tudo. Aqui é muito grande, o que a gente depender deles, eles estão pronto.

vocês demandando...

Eles estão sempre atendendo.

E de quais atividades da empresa você já participou?

Já participei de muitos cursos, financeiros mesmo. Eu tenho até o nome: recursos financeiros da parte agrícola, essas coisas... como a gente fazer um bom negócio, como vender os nossos produtos, você entrar cada vez mais no mercado aqui na nossa área.

As atividades desenvolvidas pela Emater sobre práticas agrícolas sustentáveis têm influenciado a sua visão sobre o cultivo de alimentos aqui na sua propriedade?

Tem bastante e muito. A gente passa a ter outro pensamento, outro foco para trabalhar, outro ânimo, com certeza outro ânimo.

O seu esposo tá decidindo fazer uma transição para uma produção orgânica né? você acha que a Emater influenciou nessa decisão?

Influenciou bastante e muito, só a gente vendo as práticas deles que já levou a gente em tantas chácaras, em tantos lugares dos orgânicos. Eles incentiva muito, eles estão incentivando os 
produtores mesmo a mudar para o orgânico, justamente para a preservação da nossa própria vida e do solo né? E de tudo, né?

Quais práticas você passou a utilizar na sua propriedade após participar de um projeto sustentabilidade?

A gente passou a usar várias. Agora tem o irrigas também que a gente passou a usar que a gente não conhecia, não sabia.

\section{Você lembra de mais outras?}

Eu não estou lembrada... Tem tanto curso, tanta coisa que eles vem aqui na chácara da gente. Sempre meu marido que vai para o meio da roça com eles, por isso que eu falei que seria bom com ele, porque ele teria mais informação para passar.

Participar do projeto sustentabilidade fez pensar um pouco mais sobre os cuidados com o meio ambiente?

Fez. Outra coisa que também eu lembrei, foi fazer barreiras, eles ensinam muitas barreiras, fazer os plantios.

E no aspecto de participar do projeto sustentabilidade, de pensar um pouco mais sobre os cuidados com o meio ambiente? Você acha que participar fez você pensar mais sobre o meio ambiente?

Fez a gente aprender mais e pensar melhor no impacto que às vezes você não cuidar bem disso aí do meio ambiente, o impacto que causa né? O efeito para nossas vidas mesmo. Ah mudou muita coisa viu! Esse projeto foi muito bom.

Você acredita que as práticas agrícolas mais sustentáveis podem trazer um retorno financeiro equivalente as práticas agrícolas convencionais?

Você pode fazer a pergunta de novo?

As práticas agrícolas mais sustentáveis podem ter um retorno financeiro equivalente as práticas e com as convencionais? Tipo ter uma agricultura orgânica que tenha técnicas que preservem mais o meio ambiente, você acredita que o retorno financeiro pode ser equivalente ao daquelas propriedades que não usam essas técnicas? Porque tem muita gente que fala que é investimento para o orgânico é muito grande e às vezes...

É o investimento é muito grande e o retorno é muito lento, eles falam isso mesmo. O retorno é muito lento, mas depois que você tá dentro dele, já é bem melhor. Porque o $\mathrm{M}^{*}$ tem um tio que era convencional e passou a ser orgânico e hoje ele disse que jamais ele volta a ser convencional. Ele não consegue nunca mais, mas foi difícil para ele foi muito difícil no início até ele conseguir tudo. Mas ele planta muito pouquinho. Porque orgânico você não pode plantar muito tipo convencional. Um pouquinho só, porque a mercadoria dele também é mais cara do que a convencional. Eu acho sim que retorno não é tão bom quanto convencional, mas é melhor e é o ideal.

\section{Pode não ser tão bom, mas é o ideal?}

É o ideal, com certeza. Eu acho que todo o agricultor aqui no Brasil deveria pensar nisso. Eu acho que se todo mundo passasse a ser orgânico ia melhorar para todo mundo. $\mathrm{O}$ custo podia ser alto, mas também o retorno ia ser melhor para todo mundo.

Sobre a agroecologia, o que você entende? Porque agroecologia não é só o orgânico. O que você entende sobre agroecologia? 
Você quer dizer agricultura? Como que é?

A agroecologia é quando na propriedade você consegue aproveitar tudo sem precisar de ter insumos externos. Na propriedade você consegue ter as matérias orgânicas que vai usar na fertilização, tal...

Assim o meu marido ainda não usou. Ele ainda não tá. Eu sei como que é. Aí aproveitando assim, por exemplo, lugar para colocar os lixos orgânicos né? Para poder aproveitar né? A gente não tá fazendo. Mas eles a Emater já tem orientado isso, mas só tá faltando a gente fazer isso. Mas a gente ainda tá lerdo nesse sentido.

$\mathrm{Eu}$ tenho uma cunhada que ela cantava antes dela separar. Ela fazia isso ela tinha um cantinho dela, ela falou isso que é bom para botar em planta, assim, goiaba, manga abacate, tudo... Ela disse que é bom demais, joga na terra e mistura tudo para poder plantar. Ela direto orienta a gente para fazer isso, então a gente tá perdendo tempo.

Quais as vantagens e as desvantagens de ter uma propriedade inteiramente orgânica? O que você acha de uma produção inteiramente orgânica?

Eu creio que a vantagem é muito grande, é $100 \%$ em todos os aspectos. A gente é convencional, mas tem muito sonho de ser orgânico. Nosso vizinho de baixo é orgânico, o outro é orgânico, a gente não entende muito de orgânico por ser convencional, mas pelo que a gente vê aí. A gente conversa e o ideal seria ser orgânico, com certeza.

Então você desejaria ter um modelo produtivo mais orgânico e que você não dependeria de agrotóxicos. Você e seu esposo querem iniciar esse processo de serem mais orgânicos. Quais as dificuldades vocês acham que poderiam enfrentar?

No caso aqui, a primeira dificuldade é a nossa terra. Porque a gente já usou aqui muita coisa muito. Até você consegui tirar, como é que eles falam, desintoxicar leva assim uns três anos. O primeiro ponto de dificuldades que a gente vê para nós é esse. Como a nossa terra é muito pequena, você tem que deixar uma parte sem plantar muito tempo, sem usar produto nenhum.... vamos dizer veneno, não pode usar nada de veneno e a gente não pode parar de plantar. A dificuldade nossa é essa no momento. A gente acha de passar seria totalmente radical, você tá no convencional e para orgânico. Para a gente poder conseguir o certificado é que é que é o mais difícil. A gente viu que a dificuldade maior é essa aí

Então vocês estão tentando deixa aos poucos, paulatinamente, para depois deixar um período mais longo sem usar para a terra se reestabelecer?

Isso que a gente pensa. Porque a gente já está até passando para fruta, porque a gente acha no nosso pensamento que já é mais fácil com as frutas. Também não sei se dá para passar pro orgânico depois de usar o veneno daquelas fruteiras e vai passar para o orgânico, não sei se pode ser assim também. Ai tem muita coisa para a gente buscar ainda e correr atrás.

\section{E nesse processo de modificar a produção, você acha que a Emater vai poder te ajudar?}

Pode, com certeza depende só de nós querer e procurar eles. Eles estão pronto para orientar a gente, né? A gente só não sabe mais coisa porque a gente ainda não foi buscar isso. Porque eu sei que eles estão prontos para explicar para a gente tudo. Mas toda a viagem que a gente fez esses dois anos e meio. Eles já levou a gente em propriedade orgânica. Levou a gente nessa coisa, como é que chama, agrovila? Tipo uma exposição você ia ver tudo. Então eles promovem excursões para conhecer outras propriedades. Eles levou a gente muito nos orgânicos então eles estão sempre orientando a gente. 
Entrevista n 2

Data de realização da entrevista: 29/07/2016

Duração: 43' 13"'

Aqui na propriedade mora você e o seu pai também?

Aqui nessa casa mora eu, meu filho que mora aqui nessa outra parte, meus pais moram ali, que é um casal, meu sobrinho mora entre a minha casa e meu pai, tem uma que tão mexendo ali, meu sobrinho mora ali, ali mora minha cunhada meu irmão mais dois filhos. É muita gente, ali mora os trabalhador, são três trabalhador, e do lado de cima e lá em cima mora mais um. É bastante gente.

\section{Mas nem todo mundo trabalho aqui com o cultivo?}

Não. Meu irmão trabalha e tem duas chácaras do tamanho dessa lá na Radiobrás. Ele tá plantando esse ano moranguinho ali, mas é pouquinho, ele planta mesmo e na outra chácara. Aqui quem não planta, só minha mãe que não tá plantando, porque até a minha mãe há poucos anos ela plantava, ela era a manda chuva, aí o funcionário dela teve uma insuficiência cardíaca digestiva e morreu e ela perdeu o gosto.

\section{Aqui vocês cultivam o que?}

Aqui é assim. Eu de primeira mexia com o morango. Mas eu cansei, nossa dá trabalho demais! E é muito gasto e as mudas muito miúda. Eu planto mesmo tomatinho, que e tomate sweet grape, eu planto ervilha torta, como eles chamam, eu planto vagem rasteira, pimenta, que eu sou apaixonada, não como mais planto, e brócolis americano, o que eu mais gosto de plantar é tomatinho e ervilha, eu acho lindo...

\section{Você já mora aqui há muito tempo?}

6 anos, os meus pais tem 26 quase 27

\section{Eles mudaram mais ou menos na década de 80?}

Não foi de 90, porque meu filho nasceu em 1990 e logo assim que ele nasceu eles compraram aqui. Aí quando começou sem saber o que fazer direito. Aí meu pai teve um problema de pulmão grave e o e o médico mandou ele vir morar no lugar mais tranquilo, foi aí que começou aqui a plantar.

\section{Vocês já eram agricultores antes ou não?}

O meu pai já mexeu com muitas fazendas há muitos anos atrás. Aí e agora é diferente, aqui não é uma fazenda, é uma mini chácara pequena, mas plantar acaba... não a técnica que é diferente, porque meu pai mexer com banana, coisas assim mais de grande porte. Aqui nós somos produtores familiares a gente não planta muito. É a família que cuida tem os trabalhador, mas é os meu pai que trabalha. Mas no meu caso é eu e a funcionária e um rapaz. Eu acho até que ela vai sair, mas é eu e a menina.

\section{E você decidiu ser agricultura por quê?}

Ave Maria! Eu trabalhava na cidade, fui vendedora por 19 anos e as vendas ruim. Eu não sei se você sabe, mas vendedor, chefe ele bota a gente para cobrar cheque de cliente que não paga. E eu fui me estressando com aquilo. E eu com a tendinite aí, porque mexer com 
computador. Ai foi passando o tempo e o meu filho chateado e, tava aqui no meu pai, larga disso e vem mexer com chácara. Ele que deu a ideia. E eu falei: você sabe que você tem razão. Aí eu larguei mesmo. E eu criei saúde, eu tinha problema na minha perna do nervo ciático, tinha um esporão que faltava me matar e fora a tendinite e a bursite - a bursite eu acho peguei foi aqui carregando caixa, tem essa desvantagem também. E aí com essa história vim mexer e comecei a plantando morango, e plantei morango até o ano passado. Agora esse ano eu só plantei um pouquinho para o consumo da minha filha, da minha nora, do pessoal que gosta. Mas foi assim que eu comecei. Aí apaixonei não quero sair daqui mais nunca. Eu prefiro trabalhar aqui do que trabalhar na cidade. Aqui o barulho que tenha, é do cara que tá trabalhando e não é aquela coisa que falta explodir a cabeça da gente na cidade.

\section{O que levou a sua família escolher aqui Brasilândia para morar?}

Acho que na época o meu irmão que procurou, porque na verdade ele comprou isso antes de acontecer esse fato com meu pai e aí quando foi na época de ele procurar um lugar era muito longe e aí surgiu essa oportunidade aqui e ele gostou, né.

\section{E a sua família vem de onde?}

Minha família meus pais são mineiros, eles moraram muitos anos no Goiás. A última cidade que a minha mãe morou mais o meu pai foi no Pará. E lá ruim demais! isso é há 36 anos foi em 79 que nós mudamos para Brasília, oitenta, início de 80, em Janeiro. Aí quando a mãe viu que não tinha lá, não tinha nada, não tinha estudo para a gente. Meus irmãos já tinham vindo, três morar em Brasília. As minhas tias já morava em Brasília há muitos anos. A família da minha mãe e aí com as dificuldades lá, minha mãe lógico veio morar perto da família dela. Aí foi morar em Taguatinga, minha tia mora em Taguatinga, as irmãs, a mãe dela, moravam lá agora, já faleceu. E aí com isso a gente veio com o meu pai mexer com madeireira. Na época meu pai extraía madeira no Pará e vendia por lá e quando a gente veio morar em Brasília, ele acabou montando uma madeireira no setor de indústria e junto com os meus dois irmãos. Aí foi mexer com madeira, o pó, ele descobriu que tinha problema no pulmão. Porque ele fumou 45 anos da vida dele, ele só quis parar aos 60. Ele fez 80 agora. Tem muitos anos que ele parou de fumar, mas sarar não sarou. Ele é trabalhador pra caramba e não quer morrer de jeito nenhum. Ele disse que enquanto ele consegui enrolar Deus, ele está enrolando... Mas aí com isso foi mexer com essa madeireira, acabou a gente... meus irmãos nós... somos seis irmãos, três é ralador na roça e três é na cidade. São três funcionários públicos e três que trabalham no mato, na roça. Porque como os três que vieram antes, os três conseguiram uma condição melhor para estudar e, também porque tinha outras cabeças. Porque eu não, eu tentei fazer curso de enfermagem, fiz estágio lá no HUB, mas apaixonada por essa área. Mas eu não me identifiquei tanto. Aí eu não continuei. Fiz concurso, mas teve uma tal de CPI e larguei para lá e nunca mais fiz. Aí quando eu fui trabalhar aqui gostei e não pretendo sair, a não ser que mude muito a minha vida para mim deixar de fazer. Eu gosto de muito de mexer com a natureza. Eu ando descalça, pé rachado, porque essa época da muito bicho de pé e eu acabo. Nos cachorros nem se fala... a cachorra tava ali comendo dedos dela. Mas é eu gosto é de terra, eu fui criada assim meu pai mexia com fazenda desde que eu me entendo. Então eu gosto de mexer com a natureza. Aqui a gente tem uma arara, a gente fala nós porque todos os moradores aqui aproveita a beleza dela. Ela é criada solta. E você tem de tudo. Eu acho que eu tenho de tudo. Não preciso mais do que isso aqui não. Acho que não precisa mais do que isso aqui não. Tendo a terra para plantar e a água. Nós também temos muita água, graças a Deus! Aqui tem um lençol d'água muito grande aqui nesse setor. Aqui a nossa volta não tem água para desperdiçar, mas tem água para a gente usar para as coisas que a gente necessita. E aí isso aí, é tão bom morar aqui eu gosto não pretendo mudar não. 


\section{Você sempre se imagina aqui?}

Tô vendendo uma casa que eu tenho em Taguatinga. Uma parte para pagar as minhas dívidas que são muitas, que já vem rolando alguns anos e, outra, quero comprar um pedaço de terra. Só que aqui é caríssimo, é muito dinheiro aqui nesse setor. Mas se eu não comprar aqui, eu vou comprar em outro lugar. Eu quero continuar plantando, como é que tem muitos anos que a gente planta. A terra tá cansada, o solo está precisando de descansar. Aqui são 5 hectares, você imagina... a área de plantio deve dar dois, porque a minha mãe quando ela comprou aqui, eles fizeram no juízo deles. Fizeram uma divisão da Chácara. Engraçado. Entra moradia, terminou moradia, que é uma área muito extensa. Fez o pomar mais que é grande, nossa tem uma 60 espécies de fruta do lado de lá, e no lado que passou a estrada no meio, você desperdiçou muito nosso espaço. Aí quer dizer, quando chega lá em cima tem uma área que faz um canteiro que tem $35 \mathrm{~m}$. O que é 35 metros? é nada! Aí do lado de cá acabou que ficou maior, 50 metros a mais. O lado de cá ficou menor porque descontou muito da estrada. Aí eu planto numa área pequena, a minha área é pequena. E aí agora que eu tô mudando os canteiros porque tá a estrada que eu fazia os canteiros assim, ficava muito curto. Aí que eu tô fazendo... eu tô tentando fazer eles de assimm porque a extensão assim é grande, porque é 500 metros. É 100 por 500 , da 50 mil metros quadrados, só que como tem a tal da estrada... depois se você quiser conhecer... aí eu tô mudando os canteiros, eu tô tentando, mas é tudo muito trabalhoso. Não é assim do dia para o outro, você tem que abrir uma colheita. Eu tenho uma roça de pimenta, infelizmente eu vou ter que arrancar ela, já tá fazendo uma nova para mim arrancar a velha para mim fazer os canteiros. Assim eu morro de pena, mas eu tenho que arrancar e também. para lógico, que não consigo plantar nessa minha área toda, mas a questão da terra é que você tem meios de plantar coisas que recuperam o solo. O milho recupera, o repolho recupera, é fantástico.

\section{Vocês têm feito rotação de culturas?}

Meu pai tem tentado fazer. Sim, ele tá plantando repolho. Já plantou couve, cortou ele todinho, triturou com a máquina. Eu fiz isso com couve flor que também é bom, foi bom mesmo muito. Depois deu tomate para caramba 3 meses de tomate.

\section{A renda da sua família depende inteiramente da sua produção?}

A minha depende, de todos três. Na verdade a família que é eu, meu irmão, meu pai

\section{Vocês tem algumas atividades para complementar?}

Eu, eu não tenho, eu vivo disso. Meu irmão também, meu pai aqui tem dois aluguéis, o galpão no setor de indústria e uma casa em Taguatinga Norte, mas eu não tenho. Meu pai é aposentado, então ele tem a renda dele. Ele tem aluguel também, minha mãe é aposentada, mas a renda é daqui. Assim agora mesmo, foi uma coisa essa semana passada. Eu tô correndo muito e veja o meu brócolis. Meu brócolis acabou, tá cheio de flor lá na roça. Mandei 100 cabeça, voltou tudo, não vendeu. A gente planta e depende muito do mercado. Aí chega lá e o caro fala: mais tá caro! não sabe o tanto que a gente gastou e às vezes jogou fora. Eu fico morrendo de dó. Às vezes até dou para quem quer, mas às vezes você não tem lucro. Eu viajei graças a Deus, as coisas vendeu. Agora cheguei não vende nada. A única coisa que tá vendendo bem é o tal do tomatinho, porque ninguém tá tendo, deu uma tal de praga e matou tudo. Aí a mercadoria volta. Ontem o meu irmão levou para o CEASA três caixas de ervilha. Dona $\mathrm{V}^{*}$ vendi a $\mathrm{R} \$ 25,00$ uma caixa de ervilha para não voltar. Meu irmão ainda bem que você vendeu, porque o pior que eu acho para o produtor é você cuidar plantar levar para vender e quando voltar você jogar fora. Ah gente, me dói na alma. Então assim, às vezes você tem um bom retorno. Morango não perde. Morango é a única coisa que você só plantar que 
ele tá lindo, vejo do pezinho dele, mas as outras coisas para você congelar... Uma vagem, uma ervilha, um brócolis para congelar não existe. Esse meio nós não fazemos isso. Então, assim tem muita perda, mas a gente vai vivendo né? Aí tem que ter sorte também, do que você plantou. Eu pretendo esse ano plantar ervilha o ano inteiro, eu espero esse ano vender ervilha a $\mathrm{R} \$ 100,00$. Esse ano tá acabando, mas o resto que sobra dele, porque a mercadoria, ela chega a um preço bom. Um preço ótimo, mas tem época que você tem que jogar no lixo.

\section{Você acredita que as suas atividades aqui de produção elas interferem na conservação dos recursos naturais?}

Se elas interferem? Se elas prejudicam?

\section{Se elas beneficiam ou prejudicam...}

Não, assim, em termos de produtos, de defensivos, acho que elas prejudicam. A gente... nós aqui... já eu tenho pouco tempo que tô nisso, mas já se usou muito mais produto químico prejudicando a natureza do que a gente usa hoje. A gente usa muito misturado, a gente usa muito orgânico e o químico. Eu, por exemplo, só uso químico quando o orgânico não tem mais solução quando a praga já se manifestou demais.

Quem planta orgânico já tem a própria natureza ajudando e o meio não tem... não é, não deixa a praga se manifestar. É um equilíbrio do ambiente com os insetos, porque na verdade no orgânico os próprios insetos, a própria natureza que faz a defesa. Eles planta uma coisa que ajuda o outro, que ajuda o outro, e que os insetos se alimentam um dos outros e não deixa aquilo que que vai trazer prejuízo, o pelo que eu já vi assim... A gente teve uma proposta da Embrapa para a gente trabalhar com orgânico. Mas o negócio de ir logo... Eu já venho há uns quatro anos usando produtos orgânicos, eu tô comprando de fora, porque aqui é muito caro. Mas esses dias mesmo eu estava com esse último tomate que eu arranquei. Eu vim cuidando dele desde o solo até em cima, orgânico, já tava muito alto que eu nem alcançava. Mas entrou uma lagarta, tive que tacar químico. Comprei um produto orgânico de $\mathrm{R} \$ 400$, um tal de captor, um produto fedido pra caramba, porque produto orgânico é um produto em decomposição né? Aí jogava, nada... nada... Aí tive que jogar inseticida. Aí joguei, mas eu acho assim que em termos do que prejudica hoje, no meu caso, não meu pai, porque meu pai também usa. Eu falo, ele tem que mudar a ideia, porque ele é uma pessoa que já vem com uma ideia muito anterior. E aí não tem como ele tem que ver o resultado, ele só aceitou aceitar usar o produto orgânico, porque ele viu o resultado no que eu fiz. - Não então eu quero. Aí ele viu o resultado, mas para você plantar isso na cabeça de uma pessoa é difícil. E aí a gente tenta, mas é sai mais caro, mas a gente tenta também, mas por causa da gente. Porque você jogar um produto químico, mas se você jogar um produto orgânico ele não te faz mal ele não faz mal para você, não faz mal para quem planta e não faz mal para quem vai comer a planta. Mas é uma coisa muito assim, que vai ter que trabalhar a longo prazo e buscar muito isso com as pessoas para entender isso, porque igual ao meu pai, ele ainda fica com pé atrás.

\section{Sobre a relação que você tem com a Emater, desde quando você tem sido apoiado?}

O F* que era o chefe da Emater. Eles dividiram, porque esse setor é muito grande. Não tem como eles atenderem, ensinando como planta, ensinando como cuida, né? Assim vir várias vezes atenderem a gente. Como é muita gente às vezes fica um pouco falho. Eu até hoje não conheço o novo técnico, porque já tem uns 4 meses que ele saiu e esse outro assumiu. Eu já fui lá várias vezes, mas não consegui ver, porque ele para vir aqui, eu tenho que falar e solicitar presença dele aqui. Porque não tem como ele todo dia sair visitando todos os chacareiros ou todo dia passando. Ele vai atendendo de acordo com a demanda de pedido. Então, assim, eu tô até pensando já fazer isso, porque eu tô com uns tomatinho nascendo e... 
eu tô pensando em pedir para já me dar um atendimento agora que já tá passando, na verdade, da hora. Porque eu tinha que chamar ele desde quando tava pequenininho. Porque eu não planto estufa, eu planto em campo e quando você planta na estufa você tem mais proteção por causa da estufa, como eu planto no campo acaba que você tem muita coisa para prejudicar a planta. Mas eles se você for lá pedir eles vem, eles te ensina aí te dão suporte, eles te dão tipo uma receita do que tem que ser feito o procedimento do que você vai usar, como vai usar como você vai fazer. Nessa questão eles atendem mesmo, eles são muito prestativo, eles têm essa atenção e é muito bom, porque nem todo mundo... Meu irmão paga uma grana para cuidar da roça dele. Eles fizeram aí junto com um cara, um agrônomo que trabalhava. E ele resolveu dar atendimento. Aí ele cobra de cada um, um valor, ele acaba que no final do mês tem um bom salário. E o pessoal tem uma pessoa mais ali. Porque vamos supor que eu tenho uma emergência aqui hoje na minha roça, ou nossa entrou uma praga na minha rotação, não sei como resolvo. Aí vou chamar o técnico, mas ele tem uma agenda lá. Como é que ele vai pular a agenda dele? Se ele vai ter que pular, alguém que já esperou... não fica muito fica muito falho para gente? Mas a gente tem que esperar ou a gente mantém um pedido constante, para ele está sempre vindo visitando ou eu corro risco ou eu cuido de cuidar das minhas coisas. Mas eu acho que tem pouco técnico, porque essa área é muito extensa para um técnico atender. Porque se você fizer uma pesquisa lá na Emater, perguntando... Porque olha na associação, nos tempos uma associação que tem uns 500 produtores escritos, fora os que não estão. Então você imagina um cara atender, dividir 500 pelo ano letivo, pelo ano que trabalha 5 dias, Dá 25 por mês. Como é que ele vai conseguir atender esse tanto de gente? E outra coisa ele não vai lá só uma vez, porque tem que ensinar, depois ele vai ver se funcionou e depois ele vai ter que acompanhar para ver se deu certo o que ele fez.

\section{De quais atividades promovidas pela Emater você já participou?}

Vários cursos, nossa vários cursos... Eu já fiz vários cursos na Emater central lá lá em Planaltina. Eu tenho vários cursos de agroindústria, tenho vários. Eu só não tenho na área de picles, porque tem que ter um número certo, uma quantidade de pessoas né? para fechar a turma, acho que 10. Mas eles ensinam usar o produto veneno. Veio até um cara do trabalho na questão de defensivo químico, que tem que ter um lugar de guardar, lavar embalagem, devolver para o órgão que recebe. Acho que aqui em Brasília só tem dois, esse Brasilândia. As embalagens de veneno que a gente usa, a gente tem que lavar, furar e devolver. Esse cara veio de uma boa aula. Nossa gostei demais da aula! Achei boa demais. Então a gente tem. Eles procuram muito, a $\mathrm{V}^{*}$ que é responsável, a nossa bonequinha. nossa todos os produtores dão 10 para ela. Ela é muito dedicada no que ela faz. Agora ela tá no lugar do $\mathrm{F}^{*}$ quero o chefe. Ela substitui ele. Ela é muito preocupada com a gente. Mas é muita coisa para fazer, coitada... E agora aumentou mais ainda, porque além dela fazer o que ela fazia, ela ainda faz a parte burocrática, porque ela é chefe de escritório.

Você acha que as atividades desenvolvidas pela Emater sobre práticas agrícolas sustentáveis têm influenciado a sua visão sobre cultivo de alimentos aqui na sua propriedade?

Tem

\section{De que maneira você acha que tem influenciado?}

Porque eu entendi isso ai. Não sei se é sustentabilidade você se sustentar. Entendo assim... Porque depois que eu tive atendimento deles eu plantei mais. Eu plantava sete mil pés de morango e mais nada. Eu só plantava morango igual eu falei no início, depois que eles vieram dar o suporte e ensinar a gente a plantar, né? Aí eu planto 2.500 pés de brócolis, eu planto um, quando um tá acabando eu já tenho que ter outro pequenininho. Eu não tô plantando 
brócolis agora é porque como eu viajei, eu atrasei algumas coisas e também eu perdi algumas roças. Mas com eles ensinando a gente, a gente passou a produzir mais e o lucro é maior.

\section{E quanto à conscientização ambiental? Preservar o meio ambiente... usar mais orgânicos?}

Eles não te induz muito ao orgânico ainda não. Mas a questão de embalagem de armazenamento da embalagem, devolver, como usar o defensivo químico, se proteger através de equipamentos de proteção EPI, eles dá muita ênfase pede muito e fala muito para a gente fazer. E não é só porque pode ser multado, a gente pode chegar de surpresa... É porque o benefício da gente. Claro, principalmente, o equipamento de segurança. E os funcionários detestam usar aquilo. Um dia eu vi os trabalhadores do meu pai usando um produto fedido pra caramba, químico, sem usar máscara. Aí eu falei: gente tem que usar máscara... Assim gente tem que usar máscara, mais a noção: tem o equipamento. Tem gente que não usa porque não quer, porque acha que não faz mal e faz tanto mal... Nós fizemos um curso que foi fantástico com esse cara que veio, sabe o que ele explicou? Por exemplo, as pessoas pensa que você só intoxica respirando. Você se intoxica muito mais fácil em contato com a pele do que respirando e vai para sua corrente sanguínea, instantânea. E as pessoas lá... Tem um caso de um rapaz que ele foi contaminado por produtos químicos alguns anos atrás, e hoje em dia se o vizinho passar lá na outra chácara ele está sentindo aqui e tá passando mal. É sério problema é sério e as pessoas ainda não têm consciência

\section{E depois que você participou do projeto sustentabilidade, teve algumas técnicas que foram ensinadas lá nos cursos que você passou aplicar aqui?}

Técnica de...

\section{Orientações sobre o cultivo...}

Eu tô usando muito. É... eu tô usando como eu te falei, tô usando os dois, os produtos químicos e orgânicos. A questão das embalagens, o descarte, ter que devolver lá. Eu cuido disso aí, eu devolvo direto. Eu já tô com uma casinha lá desse tamanho e já tô doida para devolver, porque me incomoda ver aquilo, porque eu sei que aquilo ali faz mal e não pode ir para o solo porque prejudica o solo. A questão do equipamento que eu acho fundamental, mas é muito difícil ainda não tá funcionando. É igual eu falei um dia para $\mathrm{V}^{*}$ : eu acho o seguinte esse curso que vocês dão de jogar produto, a gente tinha que que pegar os funcionários para trazer eles tudinho para assistir, para conscientizar. Porque às vezes quem vai é o produtor, mas o produtor já sabe, e nem sempre o produtor bota a mão na massa. Eu já joguei muito veneno. Tem veneno aí que se eu usar, se eu jogar, eu passo mal, com toda equipamento. É o que usa para matar mato que ele não é bom para você usar porque ele destrói o solo, mas a gente tem que usar porque não tem outra solução não tem outro meio, não tem que faça, mas eu me sinto péssima! Mesmo usando equipamento, botando pano, eu passo mal. Muito fedido.

\section{Participar do Projeto Sustentabilidade te ajudou a pensar um pouco mais sobre os cuidados com o meio ambiente?}

Fez muito né. Nossa como ajudou! É porque quando eu vinha não tinha noção nenhuma e também via meu pai todo doidão, aí bagunçado. Melhorou muito, porque as embalagem dele é tudo jogado. E com isso eu e ele, só que como eu tenho a mente mais aberta e ele foi vendo as coisas e aí ele começou a ter cuidado, porque antes não tinha cuidado não, era espalhado mesmo. Você olhava na roça era as embalagem para todo lado 


\section{E pensando em fazer um uso mais orgânico, mais sustentável da propriedade, pode ter um retorno financeiro... uma propriedade orgânica pode ter um retorno financeiro equivalente a uma propriedade que não é?}

Não de jeito nenhum, muito maior. Mas também o gasto é muito maior e o tempo é muito maior para você conseguir esse retorno. É por isso que antigamente eles tinham 3 anos a 4 anos para o produtor ganhar o selo de orgânico e agora eles estão querendo mudar para 2 anos. Só que para mudar para dois anos ele vai ter que ter uma estrutura, um ambiente muito natural, muito sem... eu falo assim, uma pessoa que tá começando e tem uma terra nova, aí sim! Eu conheço uma que ela é orgânica. Aqui tem um que é $100 \%$ orgânico. Acho que é o maior produtor, se não me engano, de orgânico aqui. Porque é uma coisa que demora, que não é de um dia para o outro. Se ele não tiver um ambiente, ainda começar uma terra virgem, ambiente virgem e começar orgânico. Porque se ele já tiver igual o nosso, aí vai demorar demais, porque não adianta eu cuidar aqui e os meus vizinhos é tudo tradicional. Como é que eu vou ter? Por isso que os produtores orgânicos têm barreira ao redor da terra, tem que ter barreira né? Mas geralmente esse povo novo, esse povo onde a $\mathbf{M}^{*}$ trabalha, aonde eu tô falando, ela também vende na feira, não sei se é da Asa Sul ou da Asa Norte. Tem uma feira de orgânico, eles são a maioria, são orgânico. Aí você consegue, mas como é que eu produtora... Eu gastei ano passado uma grana danada tentando comprar predadores naturais para as minhas plantas né. Só que meu pai não era, porque o predador ele... o inseto que predador, o inseto em geral ele multiplica. Só que se você não tá acompanhando o desenvolvimento da planta dele e se você vacilar uma vez e jogar o inseticida, você mata a tudo e aconteceu isso umas três vezes ano passado. E eu me chateie, porque eu vi que o meio tem que estar compatível com o que eu quero para eu conseguir. Ah... é difícil demais e às vezes você se chateia, igual aconteceu: eu sai e o funcionário tacou veneno nos meus bichinhos tudo que era os insetos para comer o ovo da lagarta. Eu comprei porque a gente compra essas coisas, hoje em dia você compra. Tem um pessoal lá em São Paulo que produz desses predadores. Mas eu fiquei chateada demais. Poxa depois de tudo que eu já fiz, foi destruído né. Aí agora eu tô usando assim... Não tô usando predadores, porque o meio ambiente aqui não tem esses insetos para me oferecer. Para mim comprar fica caro e para me manter tem essa questão aí que a pessoa que tá aí direto na planta às vezes não tem a noção do que eu tenho e faz as coisas erradas e aí...

\section{Você já ouviu falar sobre agroecologia?}

Já, já vi no Globo Rural, no programa que tem que eles passam.

\section{O que você acha desse modelo da agroecologia?}

Aqui nessa chácara não tem como. É que a terra é sofrida. É como você pegar uma pessoa velha, doente, com câncer, com um monte de coisa e querer ela revigorar e voltar a ser criança. Só se for daqui a 50 anos. Não sei 50 anos, porque eu não conheço histórico do solo assim para ele regenerar, mas se eu acredito que aqui gasta pra caramba, porque imagina eu planto aqui já há muitos anos. Eu já tenho a seis, meu pai já plantavam antes, deve ter uns 15 anos plantando no solo sem devolver para ele o que ele precisa. Porque a coisa seguinte, você vai lá e no solo. Eu fiz análise do meu solo para plantar morango, porque eu tenho Pronaf aí é uma das exigências. Aí você faz análise aí tá lá tem: isso, isso, isso. Agora o meu deu a alto teor de vários nutrientes que nem precisava voltar, mas se não tem os solos fica seco que nem um pau. Você passa a máquina que deixa ela. Tem os canteiros que eu não plantei. Ele chega e tá duro porque falta o orgânico, porque o orgânico que vai dar o fofo e a umidade, porque o orgânico trabalha muito com umidade. 
E no seu ponto de vista, para você ter uma propriedade e inteiramente orgânica quais seriam as vantagens e as desvantagens também?

Eu acho que tem mais vantagem do que desvantagens. Eu acho que se eu começar numa propriedade nova com produtos orgânicos, eu já tenho a própria natureza me ajudando. Quando você tem a natureza, você não gasta tanto, porque eu conheço pessoas que não gasta, que não compra o produto o orgânico para jogar na planta dela. Não é só a própria natureza, ela fala assim. Eu fico impressionada, mas eu aprendi que funciona e é lógico, produto orgânico é muito mais, em termos de valor, ele é mais caro. Eu acho que a transição é que é muito demorada, para mim fazer uma transição aqui que eu já venho tentando a fazer há alguns anos. Aí eu acho que de uma escala de 1 a 10, eu tenho 0,001 de avanço eu não tenho quase avanço. Chegar no 0,002 é muito longe, é muito longe para chegar a esse patamar.

Para mudar para o modelo produtivo, orgânico você enfrentaria dificuldades. Você comentou o fato do pessoal aqui em volta não pensar como você, não ser orgânico, o meio não tem favorecido. Você vê outras dificuldades além dessa?

Eu acho que os valores. Se eu precisar como é. Eu já tenho um solo muito sofrido para mim começar a dar retorno para ele, para ele manter orgânico. Para mim também as dificuldades são financeiras, porque se for comprar um produto orgânico e começar... A não ser que faz o seguinte: planta igual meu pai tá fazendo, ele planta repolho colhe um pouco, o resto ele deixa lá e passa máquina. Mas ele tem solo para fazer isso, porque a parte dele é muito maior do que a minha. Eu não tenho, se eu for fazer isso... a não ser que eu planto milho que também me dá um retorno. Mas mesmo assim é muito pouco, porque meu irmão plantou 2 hectares de milho lá e disse que não valeu muito apena. Então para mim plantar, para mim recuperar o solo e ao mesmo tempo usar aquilo lá que eu tô fazendo de recuperação, de retorno de benefício do que eu plantei, vai ser demorado. De todo jeito é demorado, mas tem que ter um começo.

\section{E nessa transição você acha que a Emater pode te ajudar?}

Assim em questão do orgânico? Assim eu não sei nem se ele.... Eu acho que eles têm esse atendimento orgânico e eu não sei quem faz isso, É porque eu nunca usei deles o que eu faço é pela minha cabeça, pelo que eu vejo, pelo que eu leio pelo que eu busco. porque na verdade há 4 anos atrás veio um cara chamado $\mathrm{D}^{*}$ que ele só vende produtos orgânicos, produtos orgânicos industrializados, porque existe produto orgânico caseiro né? Aí ele chegou com um produto chamado Bocage é um produto feito com adubo de galinha, mamona, um monte de coisa lá. Ele tem um cheiro gostoso. O adubo eu acho que ele tem um cheiro perfumado e ele é super nutritivo e ele recupera o solo. É porque como se ele fosse o sangue novo no solo, só que ele é muito caro ele é $\mathrm{R} \$ 80$ a $\mathrm{R} \$ 90$ o pacotinho. Mas se você for jogar na terra, se você for jogar em grande proporção, você vai gastar uma fortuna. Mas você vai ter um solo igual ao que era. Que nem a história: o velho volta a ser novo, mas quem vai dar conta de fazer isso, porque sai caro. Aí um dia ele ligou aqui e falou assim: $\mathrm{M}^{*}$ eu tenho produto aqui muito bom e vou te vender um pouco você vai plantar o brócolis nele, você vai ver é diferente. Com uma semana o brócolis tava uma coisa mais fantástica. Falei: nossa esse trem é bom mesmo sô! Falei igual os mineiros, porque meus pais são mineiros. Aí eu não tô te falando... Então tem que usar esse. Foi assim que eu comecei a abrir a cabeça para o orgânico. Que produto é esse orgânico? Aí eu falei. Aí meu pai viu, vendo o outro viu que eu fiquei falando que meu negócio funciona e até hoje tem os que não conhecem. Aí planta tudo ele volta e aí eu comecei. Só que o bicho começou a subir demais e eu parei de usar. Mas aí meus brócolis que davam 1500 gramas passou a dar 400 gramas 500 gramas, porque ele faz o brócolis ficar robusto. 
Porque assim dá para fazer. Tem um cara lá fora que vende uma tonelada que era $\mathrm{R} \$ 400$, mas não é a mesma coisa daquele que o cara fez. Ele é diferente você pegar o mesmo adubo, a mesma quantidade a mesma mudinha. Plantar uma mudinha aqui, uma bundinha de cá, e pegar o adubo e você vai ver a diferença dele. É muito melhor eu falo sim olha ele é caro, mas o que você dissolve em $50 \mathrm{~kg}$ de adubo de galinha ou em outro adubo, é um para $50 \mathrm{a}$ proporção boa né. Mas mesmo assim, mesmo a gente plantando, para quem planta o que eu planto hoje é muito mais do que eu plantava antes e sai muito mais caro. Mas de benefício é maior. Mas aí vem a história. Se eu tiver a sorte de ter uma vida boa na época eu tenho retorno. Eu já vendi meu brócolis de R \$3,00 aqui na roça, mas eu já joguei brócolis no lixo muitas vezes. Muito mais do que vendi entendeu? Então, assim, é muito risco o plantio. É muito risco, não é igual o cara que planta não sei quantos mil hectares de soja, de milho e vende porque ele já tem uma venda feita. A gente não tem, eu mando para o CEASA ou eu mando para Feira do Produtor que eu vendo em Vicente Pires ou então até as entregas do governo que são boas.

\section{Você participa do PAA?}

Participo, participo de tudo "p", tudo quanto ai que tem. Lá eu vendo. Só que o governo atrasou muito, agora que ele tá começando a pegar entrega. Aí como muita gente vem plantando, plantando, plantando para entregar. Eu viajei, quando eu cheguei a minha roça de brócolis eu podia entregar toda para o governo. Só que quando eu cheguei que foi aberta agenda 5 dias antes. Quando cheguei agenda já tava cheia até o dia 10, já estava toda marcada de brócolis. Aí eu vou entregar brócolis para quem? Se assim, no Ceasa tá sobrando e o PAA já tinha agendado. Aí eu perdi, aí agora tá lá numa roça de flor e geralmente dá isso. Às vezes dá pouco às vezes dá muito. Às vezes você consegue vender muito, as vezes você consegue vender pouco. Mas sempre tem perca não tem como você plantar uma planta e não ter perca, não tem. Mas aí, aí vem aquela história do lucro. Quando é assim você tem lucro, você não tira nem o que você gasta. Mas aí não pode desistir, se você vai desistir como é que vai comer o quê? Se os produtores desistir de tudo? Deus me livre!

\section{Entrevista n 3}

Data de realização da entrevista: 04/08/2016

Duração: 13' 21',

\section{Por que você se tornou agricultor? Por que razão você se tornou agricultor?}

Orgânico ou convencional?

\section{Convencional. Porque primeiramente você foi convencional, né?}

Isso vem de família, do meu pai dos avós dele. Dê muitos anos atrás.

\section{Vocês já eram daqui de Brasília?}

Eu Sou natural de São Paulo.

E vocês vieram aqui para Brasília mais ou menos...

$90 \ldots$ em 92 . 
Vocês vieram de São Paulo para Brazlândia já com a intenção de plantar?

Isso, já com essa intenção.

\section{Aí vocês compraram uma chácara lá no Incra?}

Lá no documento é INCRA 5. Mas ninguém conhece como INCRA 5, como Chapadinha.

Por que vocês escolheram Brazlândia? O que levou vocês escolherem Brasilândia para plantar?

Foi mais mesmo a oportunidade da época, da terra que a gente achou mais em conta e por não ser tão distante do centro.

Vocês acharam vantajoso comprar por lá?

Muito próximo daqui era muito caro. E aí Brasilândia foi o meio termo. Assim não era muito caro e não era tão longe do centro.

E você gosta de ser agricultor? Vocês se imagina exercendo outra profissão?

Não. No momento não.

A renda da sua família depende inteiramente das atividades de agricultura?

Depende inteiramente.

Você acredita que as suas atividades agrícolas podem interferir na conservação dos recursos naturais lá de Brasilândia?

Acredito.

Em que sentido?

Você fala..

Porque você é um produtor orgânico, então você acha que a forma como você produz contribui para a conservação lá em Brazlândia?

Exato.

Você tem essa consciência porque você tem uma técnica diferenciada na produção? É nesse sentido que você acha que contribui?

Contribui positivamente você fala... Isso

Desde quando você tem sido apoiado pela Emater DF?

Desde o início que a gente se mudou para lá. Desde o início até o momento, eles sempre têm dado apoio. Até o momento eles sempre deram com visitas técnicas. A gente vai no escritório deles e eles tão sempre auxiliando.

Você já participou de cursos?

Já sim, vários cursos ao longo desse tempo.

Quando você decidiu ser um agricultor orgânico mais ou menos?

Tem mais ou menos uns 12 para 14 anos. Exatamente eu não tô lembrado agora. Mas de 12 a 14 anos.

O que levou você a tomar essa decisão de mudar a sua propriedade para o orgânico? 
Tem a questão lógica ambiental. Tudo que a gente viu fazendo experiência... Nós lá em casa. Principalmente. Viu meu pai, viu que dava para produzir sem exagerar muito em químico, em veneno, essas coisas. Aí com o passar do tempo, foi vendo que dava para ficar isento de tudo. E também em busca de preços melhores para mercadoria, porque o orgânico tem um valorzinho melhor.

\section{E nesse processo de transição, a Emater auxiliou vocês?}

Já nessa transição em si, não. Porque na época eles não tinham muito conhecimento assim. Na época não era tão o orgânico Não era como era hoje. Tinha a pouco técnico preparado. Dentro do possível eles ajudaram, mas já foi menos um pouco.

\section{Você acredita que hoje a Emater já conseguiria ajudar mais?}

Hoje já ajudaria mais.

\section{Agora quando eles te prestam assistência já é mais voltada para o orgânico?}

Já tem uma ideia melhor. Já estão mais esclarecidos nesse assunto. Na época ainda era meio novidade, porque pouca gente sabia, conhecia para onde que ia ou o que usava, o que podia, o que não podia.

Uma coisa que eu estou percebendo é que muitos agricultores ficam receosos de fazer essa transição, porque por muito tempo a terra foi usada por um modelo tradicional. Aí depois para mudar é difícil. Na sua terra você encontrou essa dificuldade no solo para poder descontaminar?

Pela lei, eles pedem um ano. No caso se você era convencional, se você vai mudar, eles pedem um ano para essa transição. No nosso caso lá, como eu te falei. A gente foi passando pouco a pouco, foi deixando de usar, foi diminuindo a quantidade, fazendo experiência tudo... Aí foi meio assim... meio natural para sugerir a ideia, e naturalmente a gente foi adaptando.

E atualmente as atividades da Emater sobre práticas agrícolas sustentáveis, elas têm influenciado a sua visão sobre o cultivo de alimentos?

Influencia.

\section{Ela tem orientado com novas formas, novas técnicas?}

Novas ideias, novas experiências. Volta e meia eles fazem excursão para os outros estados, para as outras propriedades. Ajuda a gente a conhecer.

Essas excursões, eles fazem dentro de algum curso? Aí eles convidam os agricultores para ir?

Igual desse projeto sustentabilidade. Teve várias, 3 ou 4, não estou me recordando bem... dentro disso aí, como é que chama? Plano....

\section{Dentro do projeto?}

Projeto, isso

Que local vocês visitaram?

Teve Tacaquara, que fica aqui no PAD-DF, teve duas visitas na Água Brasília; Mais o que eu me recordo, porque eu não participei de todas.... Que eu participei foram esses dois aí. Eles fizeram outros, mas eu não participei. Foi em dias que não deu para eu ir. 
E depois que você participou do projeto sustentabilidade você modificou alguma coisa na sua propriedade?

Pouca coisa, mas teve mudança.

\section{Alguns exemplos....}

Na questão do manejo de cultura, de diversificação. Porque no orgânico, a gente tem que diversificar, não pode plantar uma coisa assim lá. Naquele espaço repetidamente. Eles esclareceram bastante, teve curso também sobre biofertilizante, de compostagem. Essas coisas ajudou bastante...

\section{Rotação de culturas?}

E isso também.

Você passou até uma atenção maior em relação a diversificação depois que você participou? Sobre o biofertilizante, você já chega fazer lá propriedade?

A gente sempre fez, só que deu umas ideias novas, mas a gente sempre fez.

E sobre o uso da água, teve alguma ideia que eles passarão? Algo assim?

Teve até na visitação da Água Brasília. Teve sim, um momento lá que falou só sobre isso. Mas tudo que eles falaram lá, já era mais ou menos o que a gente praticava.

Participar do projeto sustentabilidade lhe fez pensar um pouco mais sobre os cuidados com o meio ambiente?

Fez, sem dúvida.

Você já tinha uma consciência agora com projeto você acha que....

Clareou mais. Outras ideias novas

E você já ouviu falar sobre agroecologia?

Já.

\section{E nesse projeto chegou a ser abordado?}

Não estou bem recordado. Mas acho que não chegou a ser bem.... Se falou foi bem superficial, foi mais por cima.

Eu queria fazer duas perguntas: quais as vantagens e as desvantagens de você ter uma propriedade orgânica?

A vantagem é questão mesmo do solo. Como a gente tem uma propriedade pequena, o manejo orgânico ele te dá opção de não desgastar, degradar o solo muito rápido igual outras propriedades que a gente vê que com passar do ano vai produzir... vai diminuindo a produção, o solo vai se acabando. A vantagem é essa. A gente consegue melhor aproveitamento. E desvantagens... não tô vendo assim. Só se for questão de produção de volume que a gente perde muito para praga, para doença. Agora esse ano mesmo a gente perdeu muitos produtivos de morango, deu problema.

E o fato dos seus vizinhos não serem orgânicos, você acha que isso influencia a questão das pragas? 
Até que não. Porque nós não somos cercados por plantios muitos grandes. Só um dos quatro lados, só um lado tem plantio. Nos outros nem tem plantio.

Então você acha que as atividades dos seus vizinhos não têm impactado tanto?

Não, não. Nesse sentido, não.

Por mais que você tenha perda em relação às pragas, ainda é vantajoso porque o produto é mais caro?

Ainda tem sido mais vantajoso. Esse ano mesmo tem sido bem difícil, os outros anos não foi tão difícil como tá sendo esse. Mas ainda tá compensando, ainda está sendo melhor produzir orgânico mesmo para a gente.

Às vezes as pessoas elas ficam mais receosas de investir no orgânico por conta do tempo de retorno, porque no começo você tem que investir mais para esperar, para depois ter o retorno. Vocês tiveram essa situação?

Tivemos cinco anos desses 14 anos, mais ou menos, 5 anos a 6 anos foi difícil. Foi muito difícil. Para ter esse retorno conquistar o espaço no mercado e ter as vendas, foi difícil. Como se diz, foi difícil pagar as contas.

O que te motivou em manter a decisão de ficar o no orgânico?

Acreditar, acreditando que um dia ia dar certo, ia melhorar, esperança mesmo.

E em relação a agroecologia, você teria interesse?

Não no momento, não.

Você acha que teria mais vantagens em comparação?

Você diz agroecologia?

Sim, ter uma propriedade agroecologia.

Não, assim a nossa propriedade é pequena para esse sistema. O sistema agroecológico funciona melhor em áreas maiores, onde você tem diversidade, matas maiores, ter um ambiente propício. Tem que ter a floresta. O nosso lá é pequeno.

Lá são cinco hectares?

Mais ou menos sim, de plantio 5 hectares.

Vocês já têm o título da terra?

Lá não ainda é posse.

Concessão?

Chama posse, posse do INCRA.

O INCRA ainda precisa regular lá?

É isso é uma briga nossa de muitos anos e até hoje ainda não liberara o documento final.

Por que lá é responsabilidade do INCRA fazer a regulação?

É, há uns anos atrás ai, até fizeram reunião com a gente. Disseram que ia liberar, mas tá na conversa até hoje. 
Entrevista n 4

Data de realização da entrevista: 04/08/2016

Duração: 14' 26"'

Por que você se tornou agricultor?

Mas pela influência familiar. Meu pai já era desse ramo desde do Goiás, em 86 no se não me engano. Já nasci nesse ramo e dei continuidade aqui na parte da família.

Então vocês são de Goiás?

Seres de Goiás

Você já nasceu aqui em Brasilândia?

Não, minha mãe foi me ter no Goiás, mas toda a minha vida eu morei aqui.

Mas já eram agricultores?

Desde os primórdios, eles sempre foram agricultores, mexendo com gado também.

E aqueles vieram para mexer com hortaliças?

Foi trabalhando lá no Incra 9, perto do Setor O. Trabalhava de porcentagem, até que conseguiu ganhar o dinheiro e comprar uma propriedade aqui.

Porque que vocês escolheram Brasilândia? Teve algum motivo para vocês se mudarem para cá?

Não. Mais por indicação. Como é meu pai veio, conhecia o rapaz que ele ia trabalhar. Ele já tinha uma chácara nessa região e convidou ele para trabalhar com ele. Por isso aí quando, meu pai conseguiu comprar esse terreno que ele comprou do meu primo. Meu meu primo tem uma propriedade aqui do lado. Ele comprou uma parte da dele

A propriedade de vocês é de 5 hectares?

E isso fez 5 hecatares

E você se imagina exercendo outra profissão?

No momento não. Estou bem satisfeito com a minha profissão.

A renda da sua família depende da produção?

Depende completamente da produção.

Depende inteiramente do cultivo?

Isso

Você acredita que as atividades que você desempenha, na sua propriedade, de cultivo elas podem interferir na natureza?

Com certeza. Principalmente em relação a contaminação e recursos naturais, como a água. Cada dia tá tudo mais escasso, como se diz... necessidade de cavar mais poços artesianos para achar mais água. 


\section{Aqui a água da propriedade vem de um poço?}

É isso.

Aqui vocês são agricultores mais convencionais, né?

Isso, nada em grande escala, familiar mesmo.

\section{Vocês acabam usando alguns produtos químicos?}

Usa, defensivos também. Mas tudo com receita agrária dos lugares onde vende que é obrigatório de fiscalização e tem a orientação do uso da Emater também.

\section{Desde quando vocês têm sido atendidos pela Emater?}

Creio que a vida toda. Foi a vida toda. A Emater tem sido um órgão bem presente, ainda mais quando a gente passou a ser desse escritório do Incra 8. Eles foram bem mais presente do que era a equipe de Brazlândia.

\section{Porque o de Brazlândia tem que atender um número maior?}

Muita região, entendeu? Aí como escritório do Incra 8, Alexandre Gusmão, ficou mais com uma área menor para atender. Aí eles conseguem atender com mais facilidade.

\section{Sempre que vocês precisam eles estão aqui para ajudar?}

Sempre, em todos os aspectos. Essa semana mesmo, eu precisei deles para fazer o cadastro do Ceasa, foi no mesmo dia, eles estavam prontos para me atender.

\section{São sempre prestativos?}

Muito

\section{E de quais atividades deles você já participou?}

Praticamente tudo em relação a cursos palestras teve esse do sustentabilidade que foi quase três anos de trabalho. Excursões... Esses dias atrás a gente foi na Agro Brasília. Eles sempre entram em contato, e a gente faz questão de participar.

Nas excursões eles mesmos alugam uma van?

Isso. Normalmente, não sei qual é o método que eles usam, se há convênio com governo. Mas sempre é um ônibus ou uma van, depende do número de pessoas.

\section{Aí vocês se escrevem com eles?}

Isso. Eles ligam perguntando se a gente tem interesse de participar da excursão, aí com o número de pessoas eles vêm o veículo que é melhor.

A última ue você participou foi...?

Agro Brasília lá no PAD-DF

\section{E os objetivos da excursão?}

Era cursos, palestras aí. Estandes das empresas que elas expunham os seus maquinários, os bancos também oferecem financiamento, essas coisas...

\section{A Emater auxiliam vocês também na elaboração de projetos?}

Tanto para custeio né, para lavoura, quanto para investimento. 
E em relação as atividade que a Emater tem provido sobre práticas agrícolas mais sustentáveis, você acha que ela tem influenciado a sua visão sobre o cultivo de alimentos?

Creio que sim. E por mais, por ser uma exigência agora que a propriedade tenha que ter a sua reserva, ter uma área determinada para ser de preservação ambiental. Isso tudo influencia.

Os cursos que eles têm promovido tem ajudado vocês a pensar em um pouco mais sobre a questão ambiental?

E melhores práticas para produção.

Aqui na sua propriedade algumas técnicas que foram apresentadas no projeto sustentabilidade você já passou a usar?

Passei sim. Com tantos cursos como manejo de agrotóxicos, de IPI, essas coisas... técnicas de produção, como quebra-vento, fazer uma barreira. Tudo isso... projeto de estufa que está adequando no nosso plantio... Tudo isso... foi através de técnicas que eles apresentaram para a gente.

\section{E eles auxiliam em todo o processo desde a instalação?}

Tudo qualquer dúvida que a gente tiver, a gente liga, eles vem. Eles estão sempre presente para dar todo auxílio possível.

E você acredita que participar do projeto sustentabilidade te fez pensar um pouco mais sobre os cuidados com o meio ambiente?

Com certeza. Abre a visão da gente, porque toda vez a gente viva só o lucro, mas vê que tem todo o processo todo, como se diz... influencia no modo de ver de muitas coisas de muitas pessoas então interfere é muito importante

Você passou a entender que a sua propriedade não interfere somente no cultivo de vocês?

Não interfere no cotidiano só da gente. Interfere nos nossos vizinhos, nas pessoas que adquire os produtos da gente. Foi muito importante. Em relação à saúde aos riscos de contaminação, porque é um dos perigos de não usar de uma forma consciente é o perigo das contaminações que podem ocasionar. Foi muito importante o curso do uso do IPI, dos agrotóxicos que tivermos. Um dos maiores problemas que temos aí na agricultura hoje não só de Brasília. Não só na nossa região, mas no Brasil todo é o uso inadequado deles, porque são produtos não cadastrados para certos agricultores que é muito usado a carência dos produtos não legalizados para sete esportivos que são usados

Ter uma agricultura com práticas mais sustentáveis, uma agricultura mais orgânica, pode ter um retorno financeiro equivalente ao de uma propriedade que é convencional?

O maior problema hoje da agricultura orgânica é a comercialização. Hoje eu não consigo produzir em alta escala do orgânico, posso até produzir, mas não tem o comércio para esse produto. Por exemplo, hoje se eu estiver uma quantidade, por exemplo, de 100 caixas de morango orgânico, dificilmente eu vou conseguir vender ela no preço que seria o justo por ela, entendeu? eu vou ter que usar o parâmetro do convencional para eu poder comercializar minha mercadoria, aí se torna inviável.

$O$ custo para plantar é muito maior? 
Muito. É muitas técnicas outros produtos né? E daí que eu vejo assim, como um benefício, agora quem já trabalha com isso há muitos anos e consegue um lugar de comercialização, aí eu creio, que dizer, é o lucro bem satisfatório

\section{E aqui na propriedade de vocês, já pensaram em alguma vez a serem orgânicos ou não?}

Pensar não. A gente usa algumas técnicas orgânicas, principalmente, por causa da orientação do $\mathrm{V}^{*}$ mesmo que é bem amigo. a gente troca algumas ideias, a gente usa alguns insumos que ele indica para a gente, para melhorar a nossa produtividade. E tem sido bem satisfatório, e assim com essas técnicas, tem acabado diminuindo o uso de produtos químicos produto, agrotóxicos.

\section{Vocês usam mais em relação adubação?}

Adubação e pulverizações também. São produtos que não são químicos.

Qual seria a vantagem e a desvantagem de ter uma propriedade orgânica?

Eu creio que a vantagem, a maior vantagem seja a qualidade do produto, porque se você vai ter um produto de qualidade, tanto para sua alimentação quanto dos seus clientes. A qualidade não tem comparação. Desvantagem eu creio que seria isso, a comercialização e você produzir em grande escala, não teria tanto o comércio. Seria uma base bem menor da sociedade que consome esses tipos de produtos. Na feira do... no varejo, no Ceasa aos sábados, é um grande exemplo disso, enquanto tem 10 bancas de orgânico tem 1000 de convencional. E as pessoas que tem orgânico vende bem, muito bem,. Isso é fato, mas não se compara com o convencional. Por que muitas vezes... ainda mais nessa fase que nós estamos em nosso país, na crise entendeu? As pessoas usam muito o parâmetro do preço e não o da qualidade. Por exemplo, você tem um tomate orgânico lá, tá dez reais o quilo, entendeu? E o convencional tá $\mathrm{R} \$ 1,99$, três reais, ai a pessoa vai mais para o convencional. Só que tem um poder mais aquisitivo que consegue manter o seu parâmetro alto.

\section{E nesse momento vocês desejariam fazer uma transição?}

Não no momento não.

\section{Entrevista $\mathbf{n}^{0} 5$}

Data de realização da entrevista: 17/08/2016

Duração: 14' 38',

\section{Por que você se tornou agricultor?}

Vem de família. A gente também deu seguimento mesmo.

\section{Por que você escolheu Brazlândia para morar?}

Mudei de plantio. Plantava em cereais e passei a produzir hortifruti. Porque já tinha família que já conheci e achei melhor opção aqui. Cereais a gente só tem uma vez ao ano, hortifruti você produz o ano todo. É melhor para viver, para poder ter renda.

Primeiro você foi para o INCRA 9 juntou as economias e comprou aqui? 
Isso, morei 4 anos lá, e conseguir recurso, e comprei aqui já tem 23 anos que eu estou aqui nesse lugarzinho.

\section{E por enquanto você sempre se imagina exercendo essa profissão?}

Já não dá mais para mudar não. Já te já tenho 49 anos

\section{A renda aqui depende inteiramente da produção?}

Não tem outra renda. É só dos plantio mesmo

\section{Aí você planta morango nessa época?}

Nessa é. Porque é mais apropriado, mas a gente planta de, basicamente, quase tudo, dependendo da época do ano. Por motivo de recurso mesmo de água que é pouca. Então, quando vai chover a gente tem mais recurso, a gente pode plantar mais, a gente planta quase tudo de hortaliça. Inclusive a gente tem uma técnica bem apurada, porque muitos anos de experiência né? A gente sabe cultivar todo tipo de hortaliças.

Em relação à interferência das suas atividades no meio ambiente? Você comentou que tem uma preocupação por conta do seu filho?

Sim, a gente tem. Porque você perguntou em relação se tinha algum impacto?

Isso.

Não deixa de não ter. Porque quem mexe com agrotóxico, você acaba tendo algum impacto sim. Mas a gente tem o privilégio de ter o meu filho que se formou como biólogo. E a gente tem... A gente se preocupa muito com esta questão do meio ambiente. Mas é complicado, a gente acaba fazendo coisas que não devia né? Com meio ambiente, acaba tendo que usar produtos muito agressivo ao meio ambiente.

\section{A água aqui é de poço?}

É de poço

\section{Desde quando você tem sido atendido pela Emater?}

Muitos anos não me lembro bem... mas 90. .

\section{Mais ou menos mais ou menos quando você chegou?}

Não, passou uns tempos. Mais ou menos de 95 para cá.

\section{E de que maneira ela tem lhe apoiado?}

Sempre que a gente precisa eles estão muito disposto a servir a gente, viu? Em questão de projetos, né? Alguma receituário, sempre que a gente necessita deles, eles estão disposto a servir.

\section{Você já participou de cursos?}

Participei. Fiz administração rural, e esse, ultimamente agora, a gente terminou aquele projeto sustentação... Foi muito bom, muito bom mesmo.

\section{Por que nesse projeto Sustentabilidade tinha várias oficinas que compunha?}

Tinha manejo para agrotóxico, irrigação. Assim, no momento, não tô muito lembrado... Adubação, melhoramento na irrigação. Foi bom foi muito bom mesmo. 


\section{Participou, você e sua família também?}

Foi só eu. Porque quando um sai, o outro não pode, tem que ficar cuidando.

$\mathrm{E}$ as atividades desenvolvidas pela Emater, as atividades que ela desenvolveu sobre práticas agrícolas sustentáveis, ela influenciou a sua visão sobre o cultivo de alimentos aqui na sua propriedade?

Ah... com certeza. Influenciou e muito. A gente começa a melhorar aquilo que a gente já sabe fazer. A gente esforça mais um pouquinho para fazer melhor, porque a gente viu que dá para melhorar. Inclusive a gente foi na AgroBrasília duas vezes. Duas vezes a gente esteve lá com a Emater. Viu muita novidade no mercado. Foi muito bom.

\section{Muitas técnicas diferentes...}

Exatamente, muitas técnicas diferentes

\section{E isso te ajudou a ter uma visão diferente sobre os cuidados com o meio ambiente?}

A Emater sempre tá orientado os agricultor, ter cuidado, inclusive até coma gente mesmo. Tem muita pessoa descuidada. Você vê gente ai pulverizar uma planta e vc fala: nossa o cara é leigo em tudo, ele não sabe de nada, o perigo que ele tá correndo ali. Risco de contaminação mesmo, ficar ali até mais um problema sério de saúde.

Depois que você participou do projeto sustentabilidade você aplicou aqui na sua propriedade algumas técnicas de lá?

Não ainda não

\section{Mas você pretende?}

Com certeza, umas coisa que tem que espelhar, a gente viu né. Foi bem recente, agora a gente foi na AgroBrasília e viu umas coisa muito interessante lá. Vai tentar melhorar aqui.

Algo que te chamou mais atenção, alguma coisa que você acha que pode ser que adapte aqui na sua propriedade, você tem um exemplo?

Sobre o plantio tomate. O tomate é uma cultura muito complicada aqui para nós, sabe? Às vezes você tá usando um remédio tão agressivo e tá achando que vai ser bom e não é. Não tem essa necessidade eu vi lá, que estava expondo lá um pessoal lá, que uma empresa mexe com produto tá vendendo. Mas a gente não tinha conhecimento, a gente achava que a gente que tava certo, a gente tava com as vista tampada. Agora a gente viu. Ah vou fazer daquele jeito ali vai dar certo.

\section{Você conseguiu ver alguma alternativa que não usa os produtos agrotóxicos?}

Vi também, eu já uso já na terra. Eu já uso, inclusive acabei de usar um ali.

Qual que você usou?

Cordenil. Inclusive peguei o telefone da empresa de São Paulo, a menina me deu todo suporte, passou todos os números e fala: você vai ligar lá. Porque a gente tá tendo problema com o solo aqui. Aí conversei tal e eles vão me passar todas as técnicas para mim. Foi um lado muito bom, eu ter conhecido através da Emater.

Foi através da Emater que você conseguiu conhecer essas alternativas?

Exatamente. Foi uma empresa lá de São Paulo. 


\section{E eles entregam aqui?}

Manda um pelo Sedex, o correio deixa aqui para a gente.

Usando esses produtos que são mais químicos, causa o desequilíbrio no ecossistema e também o solo fica mais cansado às vezes, né?

O solo, principalmente. O solo cansa, ele fica muito sobrecarregado. Você fica repetindo muita cultura, aí começa a usar os produtos agressivos sem necessidade, falta de conhecimento. Agora sim tenho conhecimento. Eu fui lá na AgroBrasília e perguntei, a menina me deu um suporte muito bom, me informou, me deu o telefone para falar com a empresa lá em São Paulo. Foi muito bom, gostei. A gente já tinha uma noção, mas não sabia, tinha visto só falar mesmo, mas não sabia.

Aí você conseguiu ver outras práticas que podem ser aplicadas aqui na sua propriedade?

É...

Você acredita que práticas agrícolas mais sustentáveis, ela podem contribuir com a rentabilidade da propriedade de forma igual as práticas mais convencionais ?

Acredito que sim. Mas vai depender de como for, com o tempo. Não vai ser imediato. Essa transição leva um tempo. Leva um tempo para você conseguir.

E você tomou conhecimento sobre práticas mais orgânicas através desse projeto sustentabilidade?

Não muito, eu já tinha conhecimento que eu já tinha visto falar. Inclusive eu tenho um vizinho que é produtor orgânico.

E você chegou ouvir falar sobre agroecologia nesses cursos que você participou?

Não.

Quais as vantagens e as desvantagens deter uma propriedade orgânica?

Uaí, a vantagem é tanta que não do conta nem de falar. Você imagina, você comer o produto e saber que ele está limpo, sem problema, não vai te dar problema para saúde. É uma grande vantagem. Agora é aqui..É um pouco complicado produzir e se você não tiver produção, como é que faz? Como é que mantém a renda né? Mas dá para produzir, só que hoje também, para você conseguir o mercado orgânico, não é fácil não, porque tem grandes demandas por aí, tem os produtores convencionais, tem muita oferta.

\section{E o preço do convencional é mais barato no mercado?}

Com certeza é mais barato. É muito oferta e você com o mesmo produto aí, você pedir preço diferenciado, não é todos que vai entender.

Às vezes o consumidor não tem essa consciência...

É com certeza.

\section{E já passou na sua cabeça em ter uma propriedade mais orgânica?}

Já. Mas para ser sincero aqui nesse lugar que eu moro não tem como não, porque os meus vizinhos tem muitos que mexe com químico e não tem como contamina. E leva muito tempo para você conseguir o registro orgânico é muitos anos para você é... Esterilizar a sua terra, ela ficar no ponto de não ter mais resíduos químicos. É complicado, mas dá para você produzir 
também um produto que mesmo não sendo orgânico, mas com qualidade, né? Produzir, por exemplo, que nem o meu morango mesmo, eu passeio dentro da roça, eu tenho um menino de 9 anos. Nóis entra dentro da roça de tardizinha e é só passar o pó na roupa e come, né? Quer dizer você sabe que pode comer, porque se não pudesse, você não ia fazer isso ia? De jeito nenhum.

\section{Você tem confiança?}

Tenho confiança do meu próprio produto.

\section{Entrevista n ${ }^{0} 6$}

Data de realização da entrevista: 02/09/2016

Duração: 19' 37'

\section{Por que você se tornou agricultor?}

Na verdade são raízes. Meu pai, meus avós veio do meu pai. Meu pai veio da agricultura. A gente até teve oportunidades de escolher outra coisa, mas a gente continuou. Até os meus filhos também. Eles terminaram os estudos deles, escolheram uma faculdade, pararam no meio do caminho, porque viu os outros primos que estavam se formando e ficando na agricultura. Então o difícil da agricultura hoje é quando você trabalha de meeiro e porcenteiro. Mas quando você tem uma propriedade. Aí não. Facilita, você mesmo pode fazer o seu salário. Com isso vai... A gente vai acomodando.

\section{Tem a garantia da renda?}

Tem a garantia da renda, mas que é difícil. Por mais que é difícil, a zona rural hoje está muito moderna. Nós aqui... nós temos todo o benefício que tem nas grandes cidades, a gente tem aqui na roça. Tem telefone, tem carro, tem internet, tem wi-fi, tem tudo, água, sanitário, coleta de lixo, iluminação pública. Tendo isso a agente até acomoda um pouco e vai ficando....

\section{Aqui na chapadinha tem bastante estrutura?}

Tem, tem. Então, com isso a gente até acomoda um pouco e vai ficando

\section{Então você imagina exercendo essa profissão para sempre?}

É porque, até porque a gente gosta. Agricultura não é uma profissão, você tem que gostar, você faz porque você gosta. Lavrar a terra não é fácil. Então, você faz porque você gosta, tem que gostar.

Então, o que levou você e a sua família escolher aqui Brasilândia para morar e começar a plantar?

Eu tô em Brasília desde 79. Então, desde 79 em Brasilândia porque aqui é um polo muito produtivo e onde se concentra maioria dos produtores rurai.s $\mathrm{E}$ aí foi quando a gente conseguiu adquirir um terreno e com isso se estabeleceu. Estamos aí.

A renda da sua família, ela depende inteiramente aqui da produção, ou vocês têm outras atividades? 
Não a gente não tem outra renda, a gente vive $100 \%$ da chácara.

E aqui são cinco ou seis hectares?

Seis hectares.

Você acredita que as suas atividades, elas podem interferir na conservação dos recursos naturais?

Acredito que sim. É porque é difícil você arrancar isso de quem lavra a terra, mas a gente é conhecedor que o meio ambiente é prejudicado. Até porque falta o Estado. O Estado não é presente. Você pensa numa área, no setor que não tem o estado, é agricultura familiar. Não é porque o governo coloca lá, coloca uma renda lá, o tipo de financiamento lá no banco, e que ele tá presente não é isso. $\mathrm{O}$ agricultor, principalmente, pequeno produtor, ele não tem a presença do Estado. Então, é mais ou menos é assim tipo, tipo assim: você vai ou fica, ou faz ou deixa de fazer. Então quem tem, quem vive disso, mesmo sabendo que tem alguma coisa que prejudica o meio ambiente e até mesmo a saúde da gente, mas a gente não tendo o Estado presente. Você acaba ficando vulnerável a essas coisas.

Você acaba tendo que usar às vezes....

$\mathrm{O}$ recurso que tem as fontes que seja

\section{Desde quando você tem sido atendido pela Emater?}

Olha, a Emater existe no nosso campo desde que eu cheguei em Brazlândia, em 79, mais ou menos. Mas aí a Emater foi se estabelecer, foi mesmo dá uma assistência legal aqui, foi nos últimos 10 anos para cá. Aí a Emater, realmente é presente. Mas antes era uma coisa muito assim distante. Nos últimos 10 anos tem sido bem legal.

Nos últimos dias, nos últimos 10 anos, a Emater tem conseguido prestar mais assistência para vocês?

Mais assistência na realização de projetos, de análises de produção, análise de solo. A Emater nos últimos 10 anos tem sido muito presente, tem ajudado muito.

E quais atividades você já participou da Emater, que ela ofereceu, quais você participou?

Alguns cursos com respeito é defensivo, remanejamento de terra e curso de aplicação também de produtos químicos e defensivos.

De que maneira ela tem apoiado?

Com assistência técnica, com respeito também aos programas de governo, elaboração de projetos. Tudo. Como participar dos programas... E é isso que a Emater tem ajudado, como os produtores alcançar os benefícios vindos da parte do governo, do Estado.

Você acha que as atividades desenvolvidas pela empresa sobre práticas agrícolas sustentáveis, ela tem influenciado a sua visão sobre cultivo de alimentos aqui na sua propriedade?

Tem. Tem ajudado muito

Em que sentido ela tem ajudado a mudar a sua visão? 
Com a diminuição de uso químico, a gente tem diminuído muito, porque a Emater tem orientado a gente a usar menos agrotóxico e ensinado também como usar o produto menos efeitos, que traz menos danos. É nessa área sim

\section{Também orientando sobre adubação orgânica?}

Sim. Essas coisas, ajudando a cuidar dá produção de forma que ela vem a ser mais sustentável.

E quais as técnicas? Porque durante o projeto sustentabilidade vocês tiveram alguns cursos também tiveram a oportunidade...

De fazer exames também

\section{Exames?}

Exames toxicológicos. A gente fez. O que mais que nos aprendeu... Com respeito a compras coletiva. Também aprendemos muito isso.

E você conseguiu aplicar alguma coisa que você aprendeu lá aqui na sua propriedade?

Com certeza

Uns dos exemplos que você passou a aplicar...

Compras coletivas

Compras coletivas através da associação?

Através da associação

Qual é o nome da associação?

APA, Associação dos Produtores Rurais da Reserva A.

\section{Mais alguma técnica que você lembra?}

Aplicação de defensivos, do modo adequado. Como preservar as nascentes, manter a área de preservação. Manter uma área de preservação no caso seria, $0,5 \%$ por hectare

Aqui vocês já tinham?

Não, a gente aprendeu isso. Agora eu tenho uma área ai que não entre maquinário

Você está começando a tentar reflorestar ela?

Tô tentando fazer uma coisa que beneficia também o meio ambiente.

Procurar manter a vegetação...

É.

Participar do projeto sustentabilidade, ele fez pensar um pouco mais sobre os cuidados com o meio ambiente?

Foi. Aprendemos muito o que é cuidado com o meio ambiente. É o cuidado com o ser humano também. A gente vivia de qualquer forma, de qualquer jeito. Não sabia como pulverizar, como ter os cuidados com veneno. Aí fizemos o curso aí e veio um pessoal, aí que fizeram os exames toxicológicos. Ensinou como até, como o veneno atinge direto ou indiretamente, até a pessoa que lava as roupas tem que ter o cuidado, porque também pode sofrer danos. Aprendemos tudo isso nesse projeto aí. 


\section{Você aprendeu também sobre o uso da água?}

Aprendemos racionalizar.

Nesse projeto eles chegaram a falar um pouco sobre as vantagens de uma produção orgânica?

Falou

\section{Falou sobre agroecologia?}

Falou sobre agroecologia. É porque a produção orgânica, ela é meia complicada. É bom, mas é complicado. Então a gente aprendeu muito como ter uma produção, produzir com sustentabilidade, por exemplo, não usando tanto agrotóxico só com receita da Emater e tal. Você tem uma necessidade uma situação extrema, aí traz a Emater. A Emater observa, vê qual é o produto certo para pulverizar. Então a gente trabalhou nesse sentido. Até porque a gente, a gente é alimento daquilo que a gente produz. Então tem ajudado muito.

E quais as vantagens e as desvantagens que você acredita, no caso de uma propriedade ser inteiramente orgânica?

Olha, o custo da produção orgânica, ela triplica com a convencional. Então, assim, às vezes você tem uma economia maior produzindo convencional que a produção orgânica. Ela é... exige muito técnica e são muito caro ainda os produtos, caríssimos... Então assim, as desvantagens... é só isso mesmo é questão dos produtos que usa. Ainda tá muito caro não é todo mundo que consegue produzir orgânico, por causa disso, porque a produção convencional ela é, ela tem uma receita e... Melhor exemplo, o tomate. Você produzir orgânico ele está em média uns $\mathrm{R} \$ 40,00$ a caixa, a produção convencional em média de $\mathrm{R} \$$ 15,00 , então a diferença é muito grande. Então não é para qualquer um

E você acha que seria difícil o mercado para vender?

Não. O mercado do orgânico ele é bom para vender tá muito bom crescendo a cada ano. Cada ano cresce muito. A dificuldade é justamente isso. Porque também as nossas propriedades são pequenas. Então, nós depende muito dos nossos confrontantes para poder produzir orgânico. Eu até falo que aqui na nossa região é quase impossível produzir orgânico, porque as propriedades são muito perto muito junto então não deixa de tá contaminando, passando de uma propriedade para outra. Até porque os maquinários são os mesmos. As mesmas máquinas que faz o meu serviço faz o do vizinho que planta orgânico e não tem o cuidado de pegar a máquina e lavar, e de pegar equipamento lavar. Não existe isso do jeito que sai daqui entra lá.

Então não adianta você ter uma mudança aqui se também o seu vizinho não...

Não coopera.

E nesse momento, por enquanto você não pensa em usar mais produtos orgânicos na propriedade, algo nesse sentido?

Não eu penso, assim. Em plantar num sistema de rastreamento, só pulverizar com a receita da Emater. Com a presença de um técnico, mas mudar para orgânico, enquanto eu estiver aqui, não consigo não. A não ser que a gente adquire outra propriedade mais longe, né? Mais afastado, aí a gente pensa, porque é bom para todos, é bom para todo mundo para quem trabalha, para quem produz, para quem consome. 


\section{Entrevista $\mathbf{n}^{0} 7$}

Data de realização da entrevista: 02/09/2016

Duração: 45' 41',

\section{Por que vocês se tornaram agricultores?}

É porque a gente já nasceu já dentro dessa tradição, dentro da produção. Como a gente somo nordestino. Você sabe? O nordestão toda vida foi de uma área, onde se você não teve bom estudo, mas pelo menos os pais da gente incentivou a gente a trabalhar. Em que? Em roça, produzindo algodão, milho feijão.. Entendeu? Então a gente vem das raízes.

\section{Vocês são da onde do nordeste?}

Paraíba.

\section{Porque vocês vieram para Brasília?}

Aqui a gente.... O nordeste como acabei de falar. A gente tinha uma produção muito boa que se chamava o algodão. Então acabou a produção de algodão. Então a gente ficou sem recursos lá e a gente decidiu em que? Procurar uma vida melhor para gente. Então a gente escolheu Brasília, por que? O nordestino, a apesar de não tem estudo, a gente tem mais vantagem na área produtiva, de arrumar alguma coisa na vida. Então a gente se adaptou a isso aqui. Faz 26 anos que eu tô aqui dentro.

Vocês chegaram aqui em...

Em 89. Em julho de 89, 18 de julho de 1989.

Vocês vieram para Brazlândia?

Ficamos sempre nessa região. Do INCRA 9 para cá. Tudo é Brazlândia. INCRA 9 é Brazlândia também.

\section{E depois vocês compraram a propriedade?}

Aqui não é meu. A propriedade não é minha. Eu trabalho de aluguel há 9 anos para o rapaz dessa propriedade. Há 9 anos.

\section{Vocês arrendaram?}

É

\section{Vocês se imaginam exercendo outra profissão?}

Não a gente não tem ideia de sair da produção. Não porque aí que a gente ganha, graças a Deus, eu sigo ganhando e mantendo o padrão de vida que a gente tem, sofrida assim mesmo, mas a gente vive da agricultura.

\section{A renda de vocês toda vem da agricultura?}

Tudo da agricultura. A gente não tem outra alternativa. Porque eu tenho uma filha que tá fazendo faculdade, mas ela tem um empregozinho, estágio dela. Mas isso a gente nem fala porque é muito depende de mim do meu trabalho. Até ela se formar ter o emprego fixo.

\section{O que vocês produzem aqui?}


Aqui a gente produz morango, beterraba, batata-doce, pimentão, hortaliça em geral, folhagem, alface, brócolis, cheiro verde. E agora nesse período de chuva eu já entro com essas cultura. Agora no período seco é morango, pimentão, às vezes tomate também. Todos os anos eu ponho umas mudinha de tomate. Pouca coisa, 2 mil, 3 mil pé. Porque nós pequeno produtor não tem muito como avançar muito, porque as condições não dá. Porque está muito difícil, principalmente na área da agricultura. As sementes... $\mathrm{Na}$ agricultura tudo ficou caro, como a semente de tomate que a gente plantava há 2 anos atrás dez anos atrás. Três anos atrás eu cheguei a comprar semente de tomate a $\mathrm{R} \$ 86$ o envelope com 1000 sementes, envelopes que vem mil sementes eu pagava 8086 no máximo $\mathrm{R} \$ 88$. Hoje nós estamos pagando $\mathrm{R} \$ 545$ em mil sementes, quer dizer em 3 anos veja só o tanto que subiu. No caminhão de adubo nessa época nós tava pagando $\mathrm{R} \$ 300$ hojé mil e $\mathrm{R} \$ 1300$. Não tem, não tem como expandir mais área, por causa do custo, fica caro demais.

\section{Você têm quantos hectares aqui?}

5 hectares.

\section{Para onde vocês vendem?}

Eu tenho meu comércio no Ceasa

\section{Vocês participam do PAA?}

Participa

\section{PNAE também?}

Já participei. O ano passado eu participei. Esse ano não. Esse não, foi o pessoal ontem da Emater até me ligou para fazer essa entrega, mas eu não entreguei porque a gente não foi a secretaria ainda. Porque tem um, um bloco que é de preenchimento. Quando você entrega mercadoria você preenche o valor, o total de quilo, só que o meu como eu entreguei em 2013 eu fiz o bloco, e o bloco daqueles grandes. Então não teve como preencher, então eu usei só metade. Então eu fui lá para eles autorizarem para usar o resto do bloco para não precisar fazer outro, porque fazer um outro bloco vai gastar. Então tem que ir lá na secretaria, para secretaria autorizar eu usar o resto do bloco. Porque o cartão já está pronto e aí o dinheiro já vai caindo automaticamente na minha conta. na minha não, é na da mulher.

\section{Desde quando vocês têm sido atendidos pela Emater?}

De vez em quando, graças a Deus, eu sou um cara orgulhoso dessa parte. Porque a Emater sempre estar acompanhando quando eu sempre preciso. Eles sempre estão aqui dentro apoiando o meu trabalho, então... muita gente reclama da Emater, eu não. Tudo meu amigo, o pessoal que trabalha lá é tudo meu amigo. Eu não posso reclamar.

\section{De que maneira eles tem apoiado?}

Ás vezes eu tenho precisado de uma orientação na planta. Eles têm um técnico, um agrônomo lá formado nessa técnica. Então eu procuro muito eles para me dar orientação aqui o que tá precisando na planta, o tipo de adubação. às vezes eu participo muito, eu me considero assim porque eles me ligam para dia de campo, reuniões. Então a gente tá sempre presente com eles nessa forma. Aí é muito bom a gente trabalhar. Então para mim mesmo a Emater, o pessoal da Emater é muito importante na nossa área.

\section{Também participar nos projetos do governo?}


Nos projetos eu não participo. Porque o meu contrato aqui de arrendamento ele é anual. Então ele não dá chance para eu chegar lá e dizer, sim eu vou participar de um plano de governo, justamente como o custeio, um Pronaf para fazer. o contrato que eles me dá aqui é anual, então não dá porque se fosse 3 anos o contrato eu tinha possibilidade de participar. só que o dono da chácara ele de ano em ano renova. Olha eu precisava de um, eu não tirei um trator porque justamente o meu contrato não.. não permite, a não ser que ele seja o meu avalista e ele não gosta de ser avalista nem para família dele: 'olha eu não sou avalista nem das minhas filhas, nem se elas precisarem hoje eu não sou'. o cara já falou tudo. Ele lê muito a Bíblia demais da conta. E às vezes ele me ajuda muito quando eu preciso de um cheque. Ele me arrumou um cheque dele e inclusive a gente não trabalha muito com banco porque a gente não é muito estruturado. E se a gente puder desviar um pouco dos débitos do banco, melhor ainda, mas já teve cartas para oferecendo. Mas a gente não pega. Nessa parte aí ele me ajuda muito, porque quando eu preciso ele sempre me arrumou um cheque. aí nisso aí ele me ajuda, mas não é avalista. às vezes eu tenho que pagar frete, se eu tivesse meu próprio caminhão eu já desviava por ano no mínimo 12 mil conto 14 mil, quanto eu já desviava esse em cima do frete. isso sim já era uma renda que eu não ia ter que pagar para os outros. Então é nesse termo aí mas, nem por isso a gente vai parar de trabalhar, porque é o que eu sei fazer, graças a Deus! E tenho coragem de enfrentar.

\section{Vocês já participaram de várias atividades da Emater?}

De cursos, de tudo, tudo. Manejamento, aplicação de agrotóxico, tudo, tudo. Eu já fiz graças a Deus de plantação. Eu já tô bem informado. também 26 anos se não tivesse, até a prática já ajuda você né? tanto que o proprietário dessa chácara, ele é agrônomo. muitas vezes ele chega e ele quer discutir comigo. é porque às vezes eu tô usando... - o R* essa planta nós vamos fazer assim. aí ele disse: - não, não é assim. E às vezes a gente chega discutir, porque eu falo para ele: - eu não tenho estudo, eu tenho a prática. O senhor vem aqui de mês em mês ver essa planta, aí você vê aquele defeitinho e eu vejo não, eu vejo todos os dias e todos os dias eu tô vendo lá. Então eu tenho a prática e você tem o estudo e eu vou dizer que o senhor está errado ,você se formou para isso. Porque às vezes eu tô aplicando um produto na planta que ele vai chegar e ele vai dizer: - esse produto não facilita essa planta. Mas porque que eu tô discutindo com ele, porque eu tô vendo que aquele produto tá me servindo no dia-a-dia ali dentro, entendeu? Ás vezes a planta tá com algum tipo de bactéria, um fungo, uma coisa, que no estudo você descobre que tipo de fundo que é, mas não sabe qual é o produto para fungo que tá funcionando naquela bactéria. Aí é onde que a gente as vezes tem hora que discuti, por que esse aqui não tá servindo e eu sei que aquele produto... porque aqui vem ele agrônomo, vem o pessoal da Emater, o pessoal da $\mathrm{H}^{*}$. Então... é tudo vai orientado você e você vai pegando aquela prática. E você vai o usando o produto e vendo aquele produto que dá dando certo. Ai muitas das vezes você discute com o agrônomo por causa da prática. Porque às vezes não o estudo não, é a prática é o dia-a-dia que você tem. Às vezes eu passo 6 meses sem pedir a autorização de técnico algum aqui na minha roça. Eu só chamo quando eu vejo que não tem jeito, quando eu não estou dando conto. Ainda assim eles chega... Ano passado eu perdi 45 mil mudas de morango, eu discuti com um agrônomo de São Paulo. Eu discuti com ele bem aqui na roça, porque ele veio falar para mim que quando eu comprei as 40 mil mudas de morango... e o meu prejuízo foi total. A muda já veio com uma bactéria na raiz, que ficou lá na raiz do morango. ela já sai do viveiro com esse fungo e o que que acontece. ela sai do viveiro com esse fungo, ela chega nessa terra. a minha terra tá sem fungo, no que você põe ela na terra, o que que vai acontecer? ela vai sentir um choque é que nem nós. Nós estamos suando e estamos no rala rala, e de repente a gente toma um copo de água gelada. E você sente o choque térmico, porque vai provocar no esfriar uma dor de cabeça. Então do mesmo jeito é a planta ela tá lá e ele disse que ela tava com bactéria, mas ela não tava com bactéria 
que quando sair de lá ele não vai ver que tá com bactéria, ele só vai ver quando ela, quando transportar ela para aqui. Porque passa um dia e uma noite numa câmara fria ou às vezes nem vem câmara fria, porque isso era para ser transportado em câmara fria. Às vezes vem em cima de um caminhão já fermentando, e já é outro tipo de problema que a gente tem e quando acontece você limpou ela. eu só boto morango aqui na terra quando eu limpo ela quando, ponho na terra já limpinha e o que acontece quando eu preparei a muda todinha eu coloquei na terra com 8 dias já comecei ver a diferença, porque eu puis ela na terra e com três dias uma muda de morango, quando ela vem sem, no dia você já vê nela aquela raizinha branca que você arranca, além daquelas principal que é que nem as nossas veias. Aí com 4 dias, eu fui lá fiz o preparo do solo do jeito que eles manda cheguei e comecei ver aquela muda não tava com desenvolvimento. Algumas plantas não, vou dizer que era tudo, não era algumas plantas que eu vi que quando você coloca lá na terra com 3 dias você já vê que aquele brotozinho dela, ela vai saindo e quando ela vai saindo com força, que ela vai formando raiz, ela vai se abrindo. Então com 8 dias você já sabe se a planta vai sair. E deu 8 dias, chegou o dia de puxar para o plástico e eu já tava ligando para ele: - olha cara a muda não está saindo. - mas o que que tá acontecendo . - a muda veio com o fungo que ela não está desenvolvendo no solo, eu queria que você viesse aqui. E eu paguei $\mathrm{R} \$ 16000$ de muda e eu não vou ficar nesse prejuízo. E o cara ficou me enrolando, enrolando e enrolando. E eu digo, peraí vou fazer outra maneira. Cortei, peguei a muda e cortei ela todinha, ela já plantada e vou plantar ela e vou deixar ela sem essas folhas, para ver. Porque às vezes o problema pode ser na folha. Então eu vou podar, peguei a tesoura e podei ela todinha. Assim mesmo ela faz foi reagindo, foi reagindo... Mas eu tenho que levar a mão na muda, quando você arrancava, do jeito que você tinha colocado ela, ela tava seca, ela secou dentro das terras, ela não teve desenvolvimento, ela não formou raiz. Aí eu chamei o cara. O cara foi ver e ele ainda, ele foi falar para mim que não que era minha terra que estava com bactéria. Aí foi aonde eu discuti com ele feio: - olha você pode até ser agrônomo lá no seu viveiro aqui desse lugar, cuido eu. Aí eu botei bem dentro da lógica: - quantas mil pé de mudas você vendeu esse ano? Ele disse: - 15 milhões/ Aqui dentro de Brasília você mandou quantos milhões?/ - 3 milhões. /- Agora eu só quero que você seja sincero comigo, dessas 3 milhões de mudas que você mandou aqui para Brasília, quantos produtor já te reclamou?/ - Na realidade eh, vamos dizer que 15 produtor que pegou muita muda minha, dos 15, 14 reclamou. Mas é que nem eu falei para você, foi o preparo do solo que vocês não souberam fazer./ Ai eu disse: aí não! Eu sai arrancando cova por cova, muda por muda. /- Agora cheira aqui! - mandei ele cheirar - Cheira aqui e você vê nem uma raiz branca, tudo seca e dentro da terra, chovendo, molhada. / As muda secaram dentro do solo. Ai ele cheirou. Quando ela vem com a bactéria ela tem um, quando agente pega um negócio com mofo, não tem um cheiro forte? A mesma coisa foi a raiz, ela mofou na terra. Então a bactéria não deixou... Assim ela mofou ficou cinzenta dentro da terra. Ai eu disse: Amigão você pode ser formado, ser o que for, a muda quando ela vem boa e eu tenho é 20 anos que eu planto morango, o ano que eu pego uma muda boa a ponteira dela que não tem nem raiz. Quando vou para plantar e eu pego e solto no meio desse canteiro aqui, e não olho nem mais para trás. Eu não vou enfiar ela no chão não, e através que eu plantei e tô regando por cima. E ala lá plantou até com raizinha para cima. Ai o que acontece, ela vai puxar a raiz. Com 15 dias você puxa, já vem a mudinha de morango a coisa mais linda. Ela solta e você nem enterra ela no chão. Agora me diz a verdade? Nesse sistema ai você está certo. Agora você vem falar para mim que era o meu solo que estava contaminado. E outra se fosse o meu solo, então o Brasil inteiro tava contaminado. /Ai foi quando o cara baixou a crista, quando eu falei isso ai. Eu sei que ele me prometeu de... que eu tinha pago uma parte em dinheiro e outra em cheque. - E outra como é que a agente vai fazer, o dinheiro que já paguei não quero, só quero que os cheques, para você não depositar esse cheque. /- Vê ai outra maneira... não que eu reponha com outras mudas?/ Eu disse não: se for para eu me arriscar, ter um trabalho desse 
eu não quero./ Eu sei que saí no prejuízo, 43 mil reais de prejuízo eu tentei recuperar eles de outra forma, vou tentar por esse remédio contra o fugo. Para ver se sai alguma coisa, pelo menos se dá uma florada. Só que não deu. Dessas 40 mil mudas, eu só salvei 10. Em 40 mil, agora arranquei tudinho para entrar com folhagem. Que dizer 30 teve prejuízo, a 35 centavos a muda, ai é tanto que eu não peguei com o cara. Esse ano eu não vou mexer com morango. Só que eu não deixo, fui procurar outro viveiro, ai peguei com um cara de minas, justamente que era de um japonês. Deu certo, esse ano eu plantei pouco pé de morango. O que vem mantendo as despesas da chácara é essas mudinha de morango.

Você acredita que as atividades desenvolvidas pela Emater sobre práticas agrícolas sustentáveis ela têm influenciado a sua visão sobre a plantação?

Sim ela tem. Até as vendas mesmo já melhora muito. É muito bom.

Em que sentido, você acha... Porque esse projeto sustentabilidade ele teve uma abordagem diferenciada que era sobre a conscientização do meio ambiente. Você conseguiu perceber que você mudou um pouco a sua visão?

Mudou bastante. Porque se a gente bagunçar o meio ambiente, a própria natureza pode se revoltar contra você. Bom é mesmo você preservar. Porque aqui mesmo já era para eu ter plantado banana mesmo, como eu falei na Emater no dia curso. Já era para ser nessa cerca tudinho, arrudiando de bananeira, mas como eu tenho a reservazinha lá no fundo eu fui e falei para ela. Como eu já tenho uma reserva de eucalipto isso não vai dar problema para você. Mas hoje eu queria mesmo era plantar bananeira, assim na lateral da chácara. Que até uma ventania dessa mesmo, você tendo tipo uma barreira de bananeira, ela já impedi... Às vezes você tem uma planta que ela é de muita floração, e o quê que acontece, um vendaval desse aí ele ajuda muito abalar a planta. Então ela vai ficando frágil, a raiz dela vai se abalando e ela vai tendo um aborto de flor. Então a flor caiu você perdeu um fruto. Então com isso aí que é importante essa área aí você sempre na lateral da sua chácara, se puder plantar um capim, plantar uma bananeira, um eucalipto, uma carreira de eucalipto. Aí é muito importante.

Quais técnicas que você aprendeu nos cursos, nas visitas de campo, nas excursões que teve através do projeto... O que você passou a aplicar na sua propriedade?

Aqui é base de solo, você tá falando aplicação no solo?

\section{Assim no geral...}

No geral. O agrotóxico é um dos inimigos da gente. A gente aprende muito que o agrotóxico é um dos inimigos da gente e até para o consumidor. Você sabe, o câncer ele é provocado muito através do agrotóxico. Eu vejo muito agricultor às vezes que ele não tem a consciência dele, tão entendeu? Ele usa... Ele está colhendo um morango hoje, termina de colher aqui e ele já vem com aquele veneno forte e com três dias depois ele sabe que vai ser obrigado a colher, e ele tá aplicando aquele mesmo produto. Então você vê que em umas pesquisas, ai no laboratório em análise verdura. Umas das planta que mais tem agrotóxico se chama morango, tomate, pimentão. As outras cultura, elas não necessitam tanto de agrotóxico. Não sei se você já viu essas pesquisas, essas análises que eles faz que uma das plantações que mais a gente contém veneno, quando a gente tá se alimentando, a gente tá se alimentando de agrotóxico, é o pimentão, morango e tomate. Essas outras culturas até nem tanto, porque são as plantações que menos usa agrotóxico. Já essas outras plantas não, morango, tomate, pimentão, eles necessita mesmo ou você trabalha com um produto orgânico ou você vai acabar usando agrotóxico, você só consegue se for com agrotóxico e forte. O tomate mesmo, se você não aplicar duas vezes por semana, você não consegue colher ele. É tanto que eu mesmo que sou 
produtor, eu não como o tomate da minha roça. Eu sou consciente, trabalho com ele? Trabalho, por que é o meu meio de sobrevivência. Mas eu não autorizo, eu levo meu produto para vender, você tá comprando, tá. Mas eu tô sabendo aqui o que agente tá vendendo. Não é justo, a minha consciência fica pesada com aquilo ali, eu não vou mentir para você. Mas não tenho outra forma, eu não tenho a origem orgânica. Por que se eu tivesse a análise bonitinho e eu pudesse trabalhar com o orgânico, eu não ia trabalhar com o diabo do agrotóxico, porque eu mesmo tô me matando. Até na hora deu tá aplicando ele eu tô me mandando. Eu pego o meu morango. O meu morango eu trabalho mais com biológico, eu perco muita produção de morango. Perco, mas eu fico satisfeito, fico feliz porque você pode chegar agora na minha roça e pegar o morango e chupar. Porque eu me responsabilizo, por que se você se adoecer, só se for se você tiver uma coisinha na garganta. Mas se for do agrotóxico, você pode levar para qualquer análise aí que eu uso biológico e ele a carência dele é de 3 dias. Mas eu vejo muito produtor que às vezes que a gente fica batendo nessa tecla. se você tá colhendo um produto não aplica um agrotóxico com carência de 15 dias, de 30 dias, porque às vezes ensinamentos e muitos ficam aí assistindo não fazer esse tipo de aplicação. Então eu não acho justo também, não sou contra cada qual que faça as suas coisas do jeito que entender. eu não nego do jeito que eu tenho os meus filhos e aí fala: - pai eu quero chupar esse morango. eu falo: - pode. Eu não vou dizer não. Porque do mesmo jeito é o filho dos outros. Meus filhos primeiro para depois ter a consciência tranquila e qualquer criança qualquer, ser humano pode chegar lá. Já o tomate não eu não posso eu não posso dizer o mesmo, porque o meu tomate, a gente trabalha com ele nesse estilo. Você tem que ter o produto forte mesmo.

\section{Você consegue lembrar mais alguma coisa que você aprendeu lá no projeto que você passou a usar aqui?}

Adubação, por hectare. A gente aprendeu como uso, quanto por hectare que usa, o que mais ou menos usa. Adubo químico, adubo orgânico, a gente já tem as bases todinha. A gente já tem a base, porque quando eles dão o ensinamento, eles já dão quanto é que vai usar por hectare, entendeu? Então a gente já tem essa técnica.

\section{Você já usa adubação orgânica?}

Não. Orgânica que eu falo é assim. Nós usa a cama de frango. é essa a prática que a gente tem mais composto assim, é a cama de frango. Essa ai até não tem química. Porque essa base de adubação não traz problema nenhum para planta. Só assim um fungozinho para a sua planta. Porque acama de frango ela é terrível, ela tem aquele bagaço de arroz que já eh bem favorável a puxação de fungos. Só que é o seguinte. Você já tá acostumado a trabalhar com ele, quando você pega o adubo, você olha assim. Eu quero o da matriz, que a matriz ela vem tirada dobrada da granja, passa uma máquina três vezes então ela vem quebradinha. Então ela, agente já pede a matriz, porque a matriz já vem passada na máquina três vezes. Então ela não vem mais aquela palha. Então a gente já aprendeu a trabalhar com esse tipo de adubação que antigamente nós conhecia pela cama de frango. Areião hoje não é matriz e quando você quer trabalhar com adubo puro, já é diferente. Mas tem três tipos de adubação tenho. Areião que a palha de arroz, adubo puro e a matriz. E plantação de adubo de saco que adubo químico, aí a gente já tem a formação daquilo que usa. Porque tá, quando você vai plantar um cultivo. Aí a gente já tem mais ou menos o que a gente usa a quantidade de saco. Então a gente já tem essa técnica

Você acha que depois que você participou do projeto, você passou a pensar um pouco mais sobre os cuidados com o meio ambiente? 
Com certeza a gente tem que pensar. Hoje tem que pensar, porque hoje a natureza agradece. Se você zela por ela, a natureza lhe dá em dobro. E se você vai só explorando ela, ela chega uma hora que ela vai dizer assim: 'não, eu não vou te dar'. Eu não vejo não para mim, mas para os meus filhos, para os meus netos, por isso se você não for preservando a natureza daqui a trinta, quarenta anos, quem será de nós sem a natureza? Você vê o tanto que já mudou. Quando eu cheguei aqui em Brasília, em julho de 89, é... eu lembro bem que eu passei quarenta dias, quarenta dias, viu? Dentro de casa sem fazer nada, por quê? Com chuva... Quarenta dias vi? Que eu me lembro, a chácara inumou tudo com agua, ninguém podia fazer nada, trator não entrava dentro porque atolava, nada. A gente se colher nada. Hoje cê vê que quando chove três dias seguido cê tá achando que tá chovendo demais. Agora imagine só que há vinte anos atrás chovia quarenta dias de dia e de noite, você não via a luz do sol. Hoje você tá vendo aqui chover no máximo três dias. Isso ai tudo é a natureza respondendo, entendeu? O homem destruindo com tudo . Não sou aquela $\mathbf{M}^{*}$ que ela é ministra do meio ambiente...

\section{Ela foi.}

Tem muito agricultor que não vai assistir palestra. Ele acha que tudo é fácil. Essa árvore se você pegar o cerrote, você tá destruindo a natureza. Se você chegar você pode até arrancar ela. Mas que você tenha outra para colocar no lugar dela. Porque a natureza ela vai lhe repor entendeu. Então é isso aí que a gente aprende. Eu aprendi muita coisa nessas palestras, nesses cursos aí. Esse tipo de coisa é muito bom para nós produtor. Entendeu? A natureza ela dá e ela toma se você não souber preservar ela, entendeu? eu lembro bem que lá no nordeste, lá a gente é sofrido sobre a chuva, a gente é sofrido porque o nosso nordeste é muito rico. Só que lá gente não tem recurso e os homem ele não tem coragem de fazer, de investir para descobrir. Nós somos rico, o solo ele é rico mas ninguém tem coragem os grande não tem coragem de investir aqui. Nós contrata, contratava, hoje já tá mais difícil, hoje já tá mais complicado. $\mathrm{O}$ que a gente poderia fazer com 20, 23 metros, você descobre a água lá no nordeste, com $15 \mathrm{~m}$ você não dá conta de colocar uma bomba para jogar. Aqui uma cisterna com 20 metros é que você vai jogar uma bomba para jogar água em cima, o que vai dar no lençol freático, lá com 10 metros você já chega no lençol freático. Mas nós não podemos dizer que nós é pobre. Lá nós somos rico. Apesar de que não chove do jeito que chove aqui para gente, mas lá é rico o nosso solo, lá é favorável só que o pessoal não quer fazer investimento. A gente saiu de lá justamente por isso. Porque quem tinha condições de fazer não fez. E nem faz, entendeu? Então a gente correu para cá, por causa disso aí que a gente viu que além do pessoal para fazer aquilo, você vai incentivando para ir aprendendo. Então foi isso. Por isso que faz 26 que eu estou aqui. As veze minha mãe liga: o Deus daí é o mesmo daqui. Eu sei que o Deus daqui é o Deus dai, só que as facilidades aqui é muito mais favorável para gente, os meio de sobrevivência. Porque lá hoje você procura o trabalhador, já não tem mais. Porque o tanto de gente que trabalha naquelas fazendas pra o hoje você chegar naquelas fazenda, quando muito você encontra um caseiro olhando um molho de vaca, morrendo de fome. Antigamente você chegava em uma propriedade daquela, você via 80 trabalhador, 80 funcionários, uns produzindo outros trabalhando de vacação, porque lá no nordeste, a pessoa trabalhava muito com desmatação para plantar algodão. Agora tá lá, ninguém mexeu mais na natureza e tá lá tudo mata de novo. Não tá uma coisa mais favorável, porque as chuvas de um certo tempo pra cá... A Paraíba quando chove 15 dias de chuva no ano, já é muito, lá para nós está sendo assim. Não é que nem antigamente que chovia os 4 meses do ano, janeiro, fevereiro, março, abril. É por isso que a gente produzia muito muito milho, feijão, arroz algodão. Depois que as chuvas foram embora veio aquela praga, que acabou com os produto lá. Então muita gente fugiu do nordeste, procurar recurso fora. Porque ainda era o nosso recurso o algodão, a gente produzia muito algodão. 
Você acredita que as práticas agrícolas sustentáveis pode ter um retorno financeiro a igual a convencional?

A orgânica é sempre na frente. O lucro é maior. Enquanto você vende uma bandeija de morango convencional, $\mathrm{R} \$ 2,50$ hoje a bandejinha de morango orgânico você ta vendendo 10 12. Então a margem de lucro é muito grande. Então se pudesse de modo geral, todos os agricultor, produtor rural, cada qual colocasse em seu lugar, se todo mundo passasse a produzir orgânico seria uma grande maravilha em nosso país, nosso país inteiro. Isso ai que é importante a gente sair fora desse tal de agrotóxico, ele acaba com a gente.

\section{Quais vantagens você vê na produção orgânica?}

A convencional produz melhor. O agrotóxico faz a limpeza do inseto. Então você passa a produzir mais. O orgânico não ele é natural. Então é o seguinte, tudo dele é orgânico. Quando se fala em orgânico, se vir uma lagarta e fizer um furuzinho naquele frutozinho, mas se ela fez o coco dele em cima daquele morango, é orgânico, então é isso ai. Tu tem essas melhores, você pode colher ele até fraquinho. Mas ele é natura. Quando você vê um frutão bonito, cheio de coisa, a planta a coisa mais linda, a folha mole. Você pode desconfiar porque o negócio tá sendo bem tratado, mas é infelizmente.. A gente tem o $\mathrm{O}^{*}$ que mexe com o orgânico, de vez em quando a gente vê os produtos dele ali e ele vendendo mais caro do que a gente porque ele trabalha nessa festa do morango e bota a barraca dele do orgânico lá. Enquanto a gente vende uma caixa de morango convencional, ele vende 10. Enquanto a gente vende a dez reais, ele vende o dobro, a $\mathrm{R} \$ 30$ reais. E ele vende mais rápido do que nós. Então, se todo mundo pensasse que nem o O*, mudou a produção dele para o orgânico. Então seria bem melhor. Não é minorando a minha produção. Mas a gente também tem que ser consciente. Minha consciência é nisso aí. Você pode não ter uma boa produção, mas no que você vende é o dobro.

\section{Se fosse outra situação você mudaria?}

Eu mudaria hoje o meu sistema de trabalho, eu ia para o orgânico, mas não tenho. Porque a propriedade para ser orgânica ela tem que vir do alicerce. Não é hoje que eu vou mudar o meu sistema de trabalho aqui, porque pra isso ai eu tenho que fazer análise, a terra não vai da... a análise vai acusar que tem agrotóxico no solo. Se eu fosse para fazer hoje eu teria que pegar uma terra nova, uma terra que nunca foi plantada.

\section{Você já ouviu falar em agroecologia?}

A gente não tem muita linguagem. Por que a gente não tem estudo. Mas agente escuta. Eu sou um cara curioso. A gente escuta. Mas eles tão sempre dando essa palestra.

Quais dificuldades que você teria que enfrentar, para ter uma produção mais orgânica? A gente tentar diminuir o agrotóxico. Menos química. A gente diz assim a gente não vai produzir orgânico, mas sim um semi orgânico. Não é isso? Uma transição...

\section{Entrevista $\mathbf{n}^{0} 8$}

\section{Data de realização da entrevista: 02/09/2016}

Duração: 19' 46"

\section{Por que o senhor decidiu ser agricultor?}


$\mathrm{Eu}$, menina eu. Eu vim pra aqui para fazer um tratamento ai. 90 dias era para eu voltar para cidade mexer... porque eu mexia com comércio, na realidade. E aí me envolvi com essas plantas, tem não sei quantos anos, de 96 para cá, veja aí...

\section{Então você começou em 96?}

É.

\section{Você morava em Brasília, depois veio para cá?}

Eu moro em Brasília até hoje. Todo o dia eu vou dormir lá. Não durmo aqui de jeito nenhum. Tenho medo de ladrão. Eu vou e volto todo dia.

Então o senhor trabalha aqui...

Trabalho aqui e vou embora todo dia. Os meninos mora aqui. Mas eu não moro não. Porque eu não dou conta de correr. Eu tenho problema.... Tenho enfisema no pulmão, então a minha respiração é... Se eu correr dez metros aí, eu já entrego. E aqui oh. muitos vizinhos nossos já foi assaltado. Os bandido chega, maquina todo mundo e dá revorvada na cabeça dos cara, leva dinheiro. Já aconteceu muitas vez. O amigo nosso ali embaixo, o cara foi, roubou dele $80 \mathrm{mil}$. E o cara sabia que ele tava com esse dinheiro lá para pagar umas mudas de morango. Roubaram o dinheiro, a caminhoneta dele, ainda deu nele umas revorvada na cabeça. Roubaram o outro vizinho aqui, tiveram que ir lá no quilomentro. Chegou de noite, entrou na casa, tava ele dormindo, quando acordou foi com o revólver na cabeça. Também sabia que ele tinha o dinheiro dele em casa. Ele teve que entregar o dinheiro dele e a chave do carro, os documentos, cartão de banco. No outro dia, nove horas, foi que o pai dele deu falta dele. E é pertinho do pai dele, e lá mora muita gente. É perigoso, sabe? Quando você tem um dinheiro para dar, ainda vem e o cara te larga em paz. E quando não tem, eles pode até matar o cara. Um japonês lá embaixo foi assaltado também, roubaram dele muita coisa.

\section{Agricultor também?}

Agricultor também, todos eles é agricultor.

\section{O que levou você e sua família escolher Brazlândia?}

Olha, na época a gente comprou essa chácara aqui para lazer. Todo o fim de semana eu vinha para cá fazer churrasco, beber cerveja, nem pensava em plantar nada. Mas ai depois, eu vi, comecei a plantar. Porque eu fiquei um tempo aqui, quando eu podia ter voltado, deixei de ganhar dinheiro. Porque chácara não dá dinheiro não, só dá para você levar a vida. Agora ganhar dinheiro, igual ganha em negócio e tudo, você não ganha. Mas, aí também já velho, resolvi ficando....

\section{Foi gostando também...}

É porque na realidade, para saúde na chácara é muito melhor. Você exercita mais, queira ou não queira. Você vai olhar a planta. Um cara te chama, você vai olhar outra coisa. Vai ver o serviço. $\mathrm{O}$ ar é muito melhor, porque tem muita árvore, muita coisa. Aqui mesmo tem muita árvore, nessa chácara. Então você tem mais condição de ter uma vida melhor.

\section{A renda da sua família depende da produção?}

Se depende?

É.

Olha, eu não... na realidade depende. Os outros também, porque veve disso. Mas são mais folgado, já foram seguir uma economia melhor.

\section{O senhor também é aposentado?}


Eu sou. Mas também a aposentadoria da gente que trabalha na chácara, não dá nem para metade da gasolina que gasta. Olha, eu gasto 1700 contos de gasolina por mês. Que eu entrego as mercadoria na cidade todo dia, duas, três vezes. Eu comprei um carro fez uma ano em janeiro, nós tá em agosto. Um ano e sete mês, eu rodei 116 mil quilômetros. Agora você divedi 116 mil quilômetros por onze litros de gasolina, vamos supor dá mais de 50 mil litro, a três reais, quanto é que não dá? Dá o dinheiro de comprar outro carro, e por ai vai. A despesa é muita. É porque uma época você ganham menos, outra mais. Ganhar dinheiro para fazer as coisa mesmo, não ganha não. Mas em todo caso, para quem não sabe fazer outra coisa... tá bom. É melhor do que trabalhar para os outros.

Você acredita que suas práticas produtivas, o seu cultivo e tal, ele interfere na natureza?

Você fala se o plantio interfere na natureza? Olha, eu acho que não... acho que não. Tem que cuidar direito, não deixar nada que dá poluição. Essas coisas tem que evitar. Mas a gente recolhe tudo quanto que é embalagem de veneno, tudo que pode ser prejudica a natureza, a gente evita.

\section{Você tem sido atendimento pela Emater desde quando?}

Não é muito tempo não, deve ser de uns 5 anos para cá.

\section{E de qual tipo e atividade você tem participado da Emater?}

Ah... A gente vai em muita coisa. Toda reunião que eles faz a gente tá lá. Agora assistência na planta para gente, assim que um agrônomo vem dar assistência, isso não vem não. Não sei se é porque a gente não é de chamar muito. Agora eles ensina muita coisa, faz reunião, aí você participa da reunião, faz palestra, você aprende o que é preciso.

\section{Você participou de vários cursos?}

Já, já. Toda vez que tem, eles avisa e a gente vai.

\section{Visita de campo também?}

Eu já fui em várias. Fui a daculá, Planaltina, fui dá PAD-DF. Já fomos muita vez.

Você acredita que as atividades promovidas pela Emater, que convida você para reunião e tal, elas têm ajudado a mudar a sua visão sobre o cultivo de alimento?

Ajuda, porque você tem mais. Você fica tendo conhecimento melhor do que você precisa fazer. Aí ajudou e tal. E eles ajuda também muito se a pessoa precisar de financiamento essas coisas. Eu nunca fiz financiamento, eu fiz para comprar esse carro. Eu comprei pelo... foi no Mais Alimentos. Que agente entrega mercadoria para eles. Entregava agora não tão pegando nada.

\section{Você entregava para o PAA?}

Entreguei. PAA, para aquele, para associação também. Agora não tem nada pegando, a gente tem muita mercadoria e não tem... tem que vender para cá também.

\section{Você vende no Ceasa também?}

Não, o meu filho que vende, que leva quando eu tenho algumas coisa sobrando. Porque eu arrumei umas entrega no mercado, tomatinho, morango, brócolis, essas coisas eu entrego direto no mercado. Agora o que a gente não entrega ele leva.

\section{E o mercado é da onde?}


Eu entrego na rede de mercado Tókio, japonês. São cinco mercado. Taguatinga, Águas Claras... muitos lugar. E eu tô entregando em dois mercado dia, um atacadista que tem aí. Eu tô até entregando tomatinho.

E você acha que as atividades sobre práticas agrícolas sustentáveis... você acha que tem também influenciado a sua visão?

Não... É muito bom.

E você participou do Projeto Sustentabilidade?

Participei

E você participou até o começo desse ano? Terminou o atendimento para vocês....

Terminou no início do ano, parece.

E você acha que participar desse projeto fez você pensar mais sobre o meio ambiente?

Ah... É muito bom. Fez sim. Embora que a gente assim, a gente trabalha numa área que aqui não tem. Porque o lugar que é mais perto de rio, essas coisas, que é mais fácil de prejudicar o meio ambiente, né? Porque a gente trabalha num lugar alto, aqui não tem água, a água que agente trabalha vem de poço artesiano, já sai direto de lá do reservatório. De lá da irrigação, aí não tem muito o que sobrar para prejudicar.

Depois que você participou do Projeto Sustentabilidade você usou alguma coisa que você aprendeu lá aqui?

Olha, na realidade usou né. Porque tudo que a gente aprende e é útil para o desenvolvimento da gente e de evitar o que é preciso para não prejudicar o meio ambiente, a gente pratica.

Como usar os defensivos...

Tudo. Defensivo aqui quando a gente usa, já junta as embalagem, já vai deixando guardado para entregar lá... Porque tem um lugar que recolhe . Ai a gente entrega lá

E manejo do solo...

Não por enquanto não apliquei nada que foi... Porque não precisou também.

Você acredita que ter práticas agrícolas mais sustentáveis ela pode beneficiar a sua produção?

Uaí, pode né. Pode sim. Porque aí a gente tem que fazer, levar o seguimento que eles ensina. Se você levar certinho, claro que vai ser mais bom pro solo e para quem tá usando também.

E quando você pensa no orgânico, você acha que ele tem uma restabilidade boa?

Orgânico tem uma rentabilidade boa. Só que a gente não tem assim, no caso do orgânico uma pessoa para ensinar a gente tudo que é preciso. Porque às vezes o cara ensina você a plantar o morango, mas você não vai ficar plantando só o morango. Então tinha que ter um técnico para ensinar todas, as várias qualidade de planta. Igual o tomatinho orgânico seria muito bom, o brócolis. Aí era bom, mas não tem, porque não tem esse técnico orgânico à disposição para ensinar as pessoas, não tem.

E você desejaria ter uma propriedade que usasse menos produtos químicos? 
Ah! Aí era bom demais até para gente mesmo. Porque mexer com agrotóxico, é um trem muito ruim, não é bom não. A gente mexe porque sem o agrotóxico você não colhe nada se já não foi iniciado um plantio orgânico desde o início, porque dai já usa as coisa proporcional para aquilo ali para não dar as pragas. Amanhã mesmo, amanhã é a sábado? É, parece que tem uma, parece não, tem uma reunião ai na festa do morango de plantio hidropônico. É uma coisa muito interessante, ne? Se não for difícil e complicado, quem sabe não seria melhor do que plantar assim. Porque a gente vai plantando nessas terra, essa terra vai ficando velha aí ela vai criando mais coisa na terra que prejudica a planta, não produz igual produzia aqui muitos anos atrás. De jeito nenhum e se for hidropônico ou de outro tipo, você não vai usar a terra velha. Porque você vai por o adubo na própria. E é tudo novo.

E para ter uma propriedade mais orgânica, quais atividades você enfrentaria para além de ter um técnico?

Eu acho que teria que fazer tudo já

Após você participar do projeto sustentabilidade você começou a pensar mais sobre os cuidados com o meio ambiente?

Ah, mas a gente. Em diferente disso ai a gente pensava. Mas ai você vai aprendendo mais coisa, você passa a cuidar mais.

\section{Aprendeu novas técnicas...}

E como tem que ser usado também as coisas. Porque antes a gente usava as coisas, largava litro de trem, de veneno encostado em um canto e não pode. Tudo tem ser guardado na norma certa. 